من أهم مرتكزات نجاح عملية التخطيط الاستر اتيجي بالجامعات أن يكون لديها

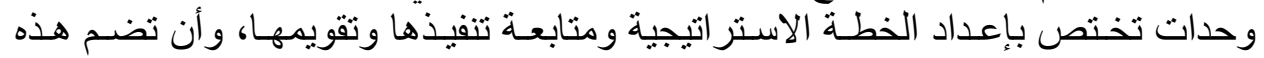

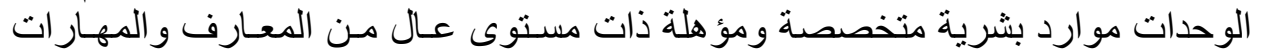

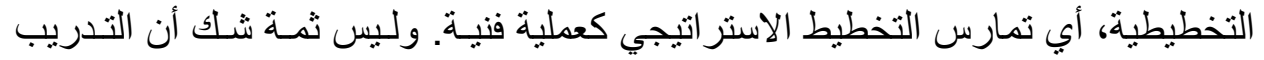

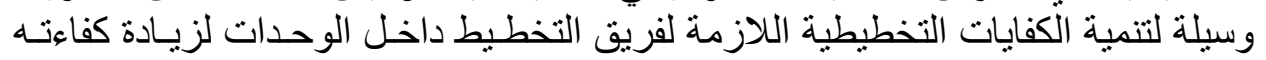

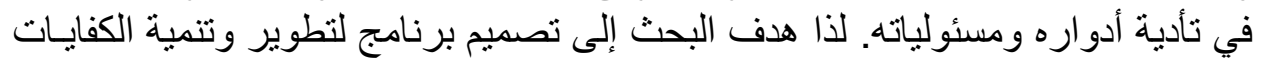

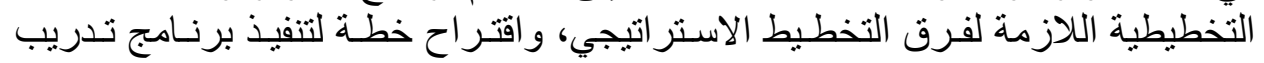

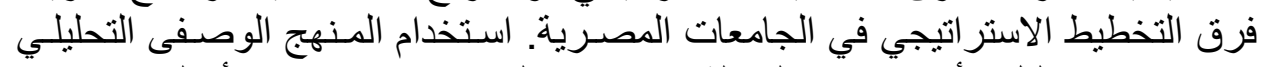

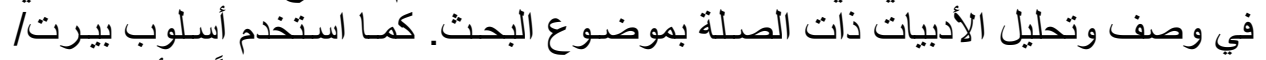

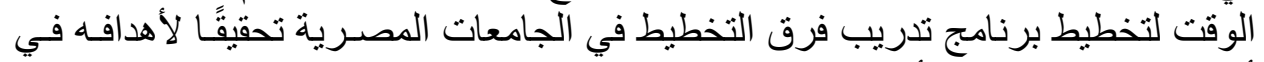

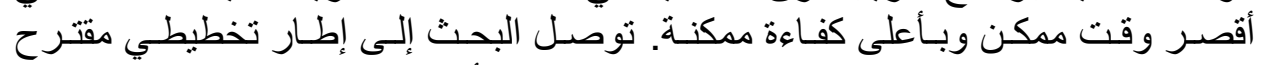

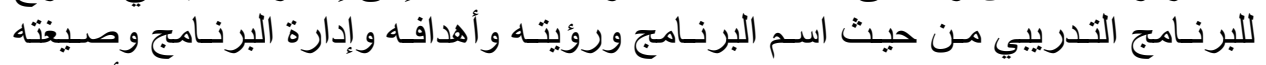

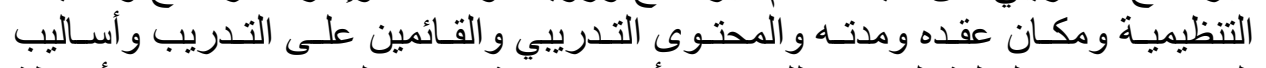

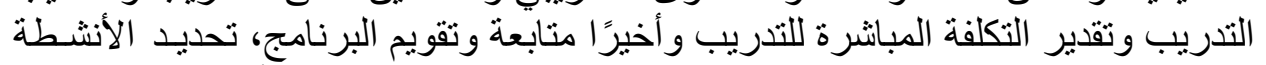

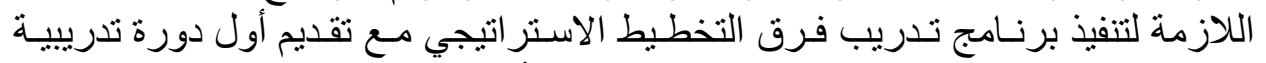

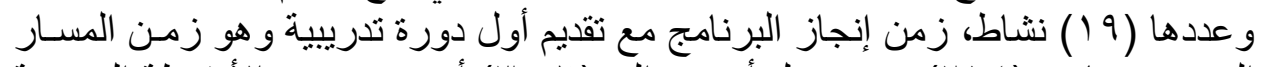

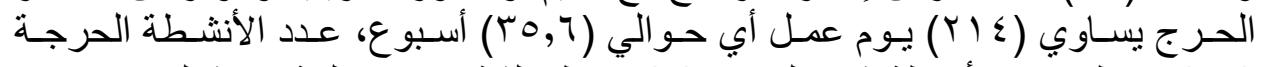

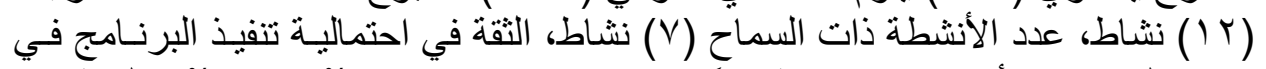

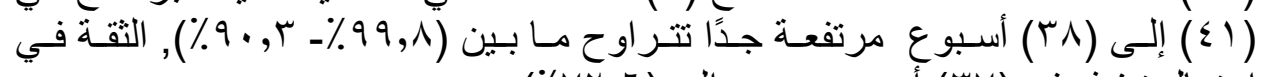

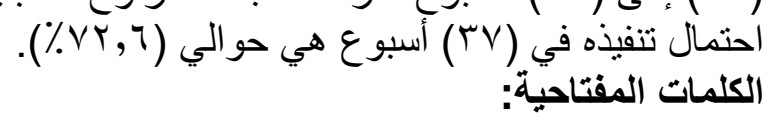

التخطيط، التدريب، التخطيط الاستر اتيجي، أسلوب بيرت PERT .

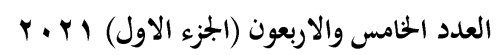

مجلة كلية التربية- جامعة عين شمس 


$$
\text { استخدام أسلوب بيرت PERT في تخطيط برنامج لتلتريب فرق التخطيط الاستراتيجي في }
$$

\section{Using The PERT Technique in Planning a Program to Train Strategic Planning Teams in Egyptian Universities}

\section{Abstract}

One of the most important pillars of the success of the strategic planning process in universities is that they have units that specialize in preparing the strategic plan, following up on its implementation and evaluating it, and that these units include specialized and qualified human resources with a high level of knowledge and skills planning, it exercises strategic planning as a technical process. There is no doubt that training is a means of developing the necessary planning competencies for the planning team to increase its efficiency in performing its roles and responsibilities. Therefore, the research aimed at designing a program to developing the planning competencies necessary for strategic planning teams, and to propose a plan to implement a program for training strategic planning teams in Egyptian universities. Use the descriptive and analytical method in describing and analyzing the literature related to the research topic. it also used the BERT / Time technique to planning the training program for planning teams in Egyptian universities to achieve its goals in the shortest possible time and with the highest possible efficiency. The research reached a proposed planning framework for the training program in terms of the name of the program, its vision, objectives, program management, organizational formula, place of holding and duration, training content, trainers, training methods, estimating the direct cost of training, and finally the follow-up and evaluation of the program, determining the activities necessary to implement the strategic planning teams training program with the presentation of the first course Training and its number (19) activities, the time for completing the program with the presentation of the first training course, which is the time of the critical path equal to (214) working days, or about (35.6) weeks, the number of critical activities (12) activities, the number of activities with permission (7) activities And confidence in the likelihood of implementing the program in (41) to (38) weeks is very high, ranging between $(99.8 \%-90.3 \%)$, and confidence in the probability of implementing it in (37) weeks is about (72.6\%).

\section{Keywords:}

Planning, Training, Strategic Planning, PERT Technique.

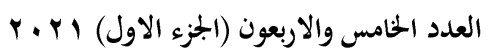

(186)
مجلة كلية التربية- جامعة عين شمس 


\title{
استخدام أسلوب بيرث PERT في تخطيط برنامج لتدريب فرق التخطيط الاستراتيجي في الجامعات المصرية
}

\author{
ع عإِ

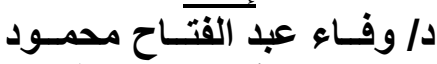

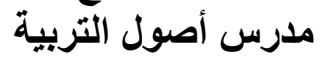 \\ كلية التربية - جامعة بنهي التربية
}

مقدمة:

في ظل مـا يعيشـهـ العـالم في تلك الآونـة مـن حالـة اضطر اب تتصف بـالتغير

و التطور السـريع متعدد الجوانب، تتضـح أهميـة مواكبـة الجامعـات لتطـورات العصـر،

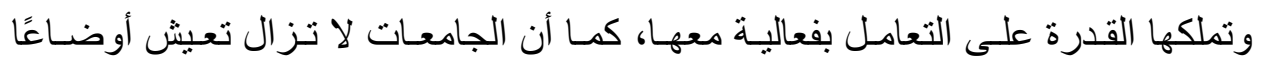

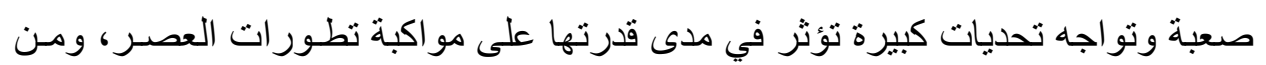

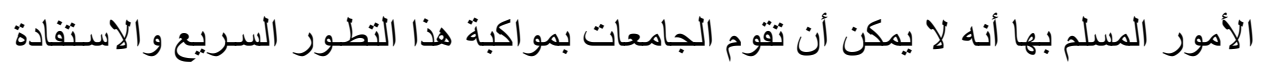
من كافة الإمكانات إلا من خلال التخطيط السـليم. ويعتبر التخطيط الاستر اتيجي المـنهج الذي يمكن من التعامل الفعال في خضم التغيرات التي تجـئ مـن كل صـوب مـن البيئـة

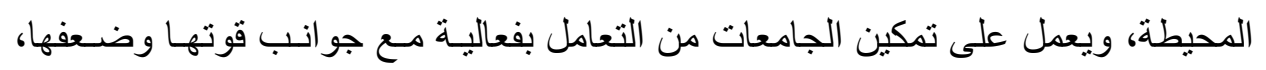
و الفرص و التحديات التي تحويها البيئة المحيطة.

و التخطيط الاستر اتيجي للجامعات بتضمن العمليات المتكاملة ذات العلاقة بتحليل البيئة الداخلية و الخارجية لها، وصياغة خطة استر اتيجية مناسبة وتطبيقها وتقييمها، وذلك

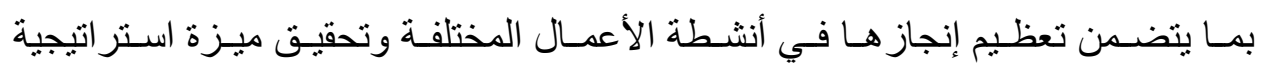
للمؤسسة، ويتم ذلك بمجمو عة من الخطوات: تحليل البيئة الداخليـة و الخارجيـة للمؤسسـة، تحديد الخيار ات الاستر اتيجية، صياغة رسالة ورؤية المؤسسـة وتحديد غاياتها و أهدافها الاسـتر اتيجية، و التحليـل الاسـتر اتيجي، وصـياغة الخطــة الاسـتر اتيجية، على مسـتوى الجامعة، و على مستوى الكليات، ويلي ذلك تتفيذ الخطة الاسـتر اتيجية، ثم متابعـة ورقابـة وتقييم الأداء للتأكد من أن أهداف المؤسسة مدركة ومنجزة.(المخلافى، 9 ( ب ؟، ع) 


\section{استخدام أسلوب بيرت PERT في تخطيط برنامج لتدريب فرق التخطيط الاستراتيجي في الجامعات المصرية فيطاية}

ويهـدف التخطـ بط الاسـتر اتيجي إلـى ربــ الأهـداف الاسـتر اتيجية للجامعـة

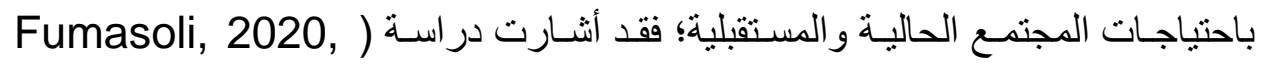
2588-2589) إلـى أن الجامعـات تحتـاج إلى التخطيط الاسـتر اتيجي كطريقـة لإعـادة

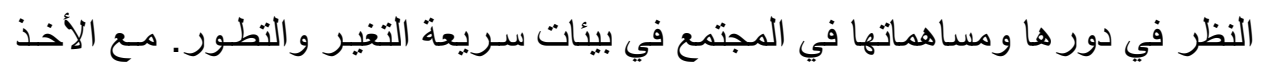

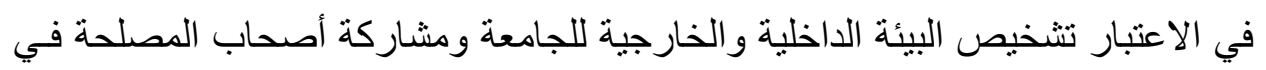
عملية التخطيط وضرورة التكيف باستمرار مع البيئات المتغيرة. لذلك يعتبر وضع خطة استر اتيجية من أولويات الجامعة حيث يتضح مسن خلالها الطريق الذي ستسـير فيـه الجامعـة في المستقبل مـن حيث الرؤيـة و الرسـالة والغايـات و الأهداف الاستر اتيجية، و البرامج و المشرو عات و الأنشطة التي تساعد على تحقيقها، بمـا يساعد على تطوير الأداء الكلي في الجامعـة ويحسن وضـعها التنافسـي. و إنجـاز خطـة استر اتيجية سليمة تتضمن عددًا من الخطط التنفيذية يحتاج إلى كوادر بشـرية على داريـة تامة بمنهجية التخطيط الاستر اتيجي. وتعتبر عمليـة الإعداد للتخطيط الاستر اتيجي هي الخطوة الأولى في طريـق الوصول إلى خطة استر اتيجية سليمة وجيدة؛ فكلما كان الإعداد جيدًا كلمـا كانت الخطـة

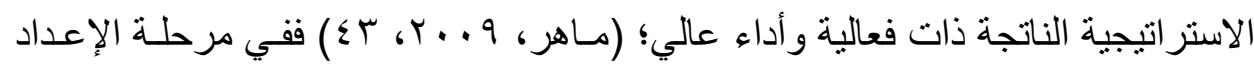

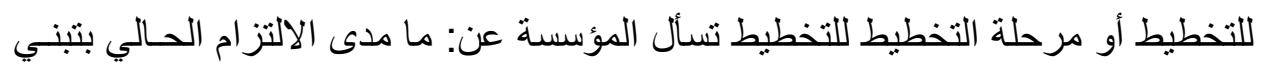
فكر التخطيط الاستر اتيجي؟ ومـا الفترة الزمنيـة اللازمـة لعمليـة التخطيط الجديدة؟ ومـا المعلومات اللازمة لنجـاح عمليـة التخطيط؟ ومـن يجب إثــر اكه ضـمن فريـق التخطيط الاستر اتيجي للمؤسسة؟ وكيفية إقناع جميع أفر اد المؤسسـة بالمشــاركة الفعالـة في عمليـة

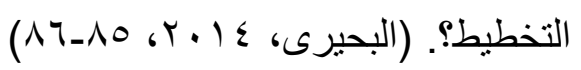
ولقد أكد (Bryson \& Alston,2005, 38) على أن الخطوة الأولى في عملية التخطيط الاستر اتيجي تتمثل في تحديد الأشخاص أو المجموعـات الذين ينبغي أن 


\section{داء وفـاء عبد القتــاح محمـود}

يشاركوا في عملية التخطيط، وتحديد ما إذا كانت جهود التخطيط عمليـة داخليـة بحتـة أم أنها ستشمل أيضًا أصحاب مصلحة خـارجيين، وتتـكيل لجنـة مركزيـة لتنسيق التخطيط الاستر اتيجي التي تحدد سياسة العملية والتوجهات، وتتكيل فريق التخطيط الاستر اتيجي الذي ينست العمليات ويخطط للأنشطة والاحتياجـات على المستويات الفر عيـة، واختيـار فريق استشـاري إذا لزم الأمر من خبر اء مسـتقلين للعمليـة ( يمكن أن يكون مـن خـارج المؤسسة)؛ وذلك للمساعدة في تصميم العملية التخطيطيـة وتسـهيلها وتخصيص الموارد و الإمكانات اللازمة للقيام بذلك.

فمن أهم مرتكز ات نجاح عملية التخطبط الاستر اتيجي بالجامعـة أن يكون للديها

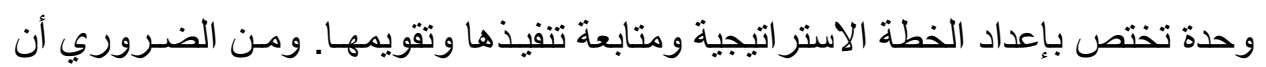

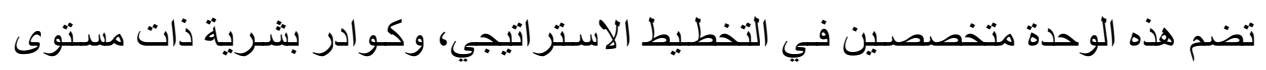

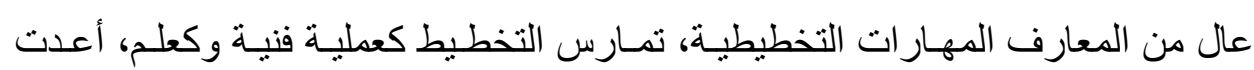
لللك، وحاصلة على مؤهلات علمية وخبرات في مجال التخطيط، بالإضـافة إلى ممنلين

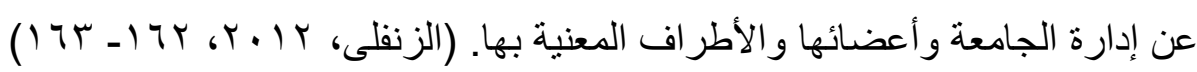

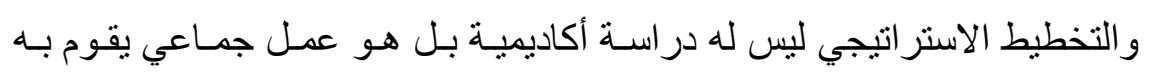
مجمو عة من الأفراد ذوى تخصصات مختلفة، ولم يجد مكانًا مناسبًا حتى الآن في منـاهج الجامعـات، وبسبب تجاهل الجامعـات للار اسـات التخطيطيـة؛ فقد وجد التخطبط مكانًا مناسبًا له في معاهد خاصة اقيمت لهذا الغرض، وحتى هذه اللحظة لا يوجد العدد الكافي

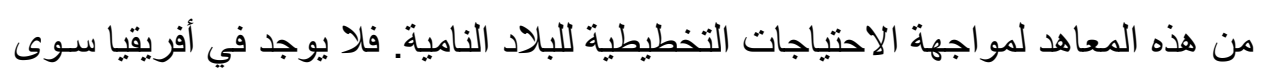
معهد التخطيط القومي بالقاهرة الذي يحوي شـعبة التخطيط الاجتمـاعي والقوى العاملـة،

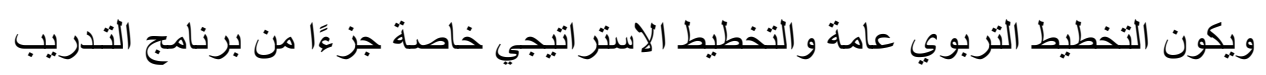

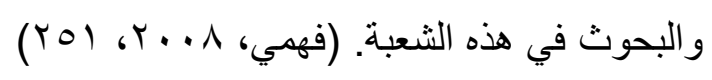

وفي كثير مـن الأحو ال لا يكون المخططون هم أولئك الأفر اد الذين يثـغلون

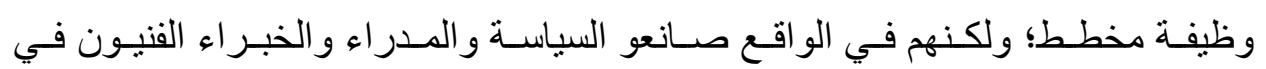

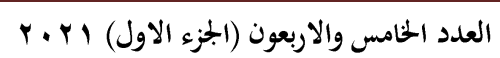

(189)
مجلة كلية التربية- جامعة عين شمس 


\section{استخدام أسلوب بيرت PERT في تخطيط برنامج لتدربب فرق التخطيط الاستراتيجي في الجامعات المصرية}

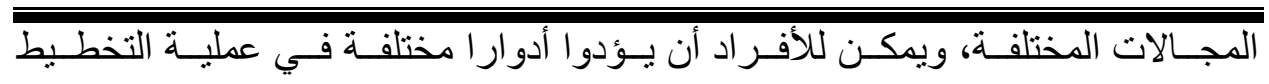

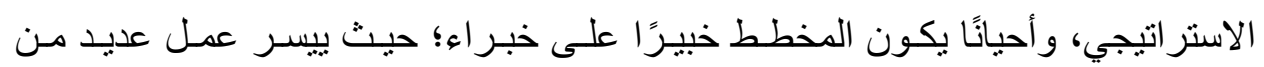

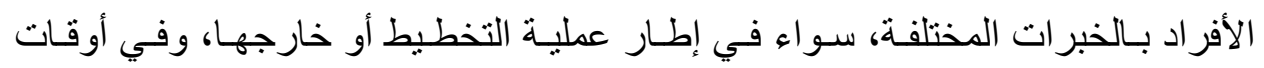

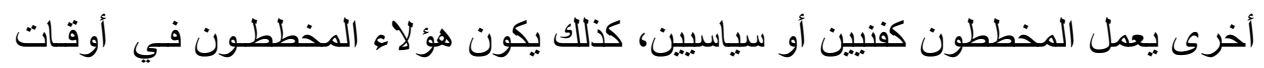

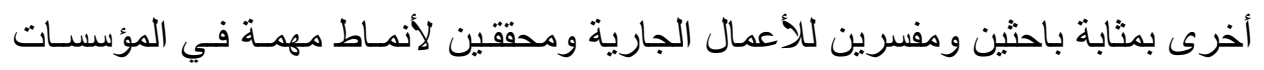
و البيئة المحيطـة بهـا ومحللين للاسـتر اتيجيات القائمـة ومحركين لتعزيز الفكر و الأداء

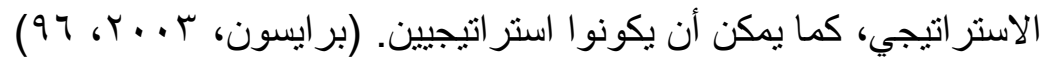

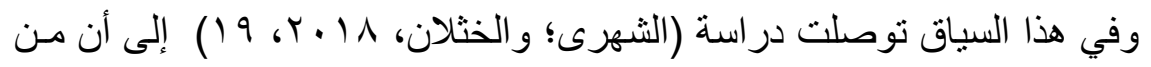
أهم معوقات التخطيط الاسـتراتيجي في الجامعـة تتمثنل في عدم تمكن فريـق التخطيط الاستر اتيجي من الكفايات اللازمة لعملية التخطيط، وإهمال استخدام المداخل والأسـاليب

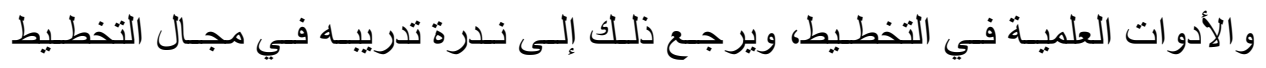
الاستر اتيجي.

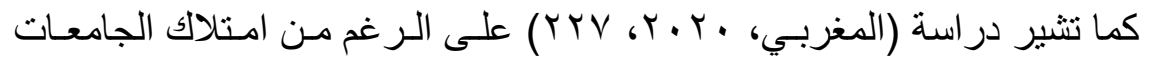
الحكومية لخطط استر اتيجية رسمية ومعلنة، ووجود فرق للتخطيط الاستر اتيجي بأغلب

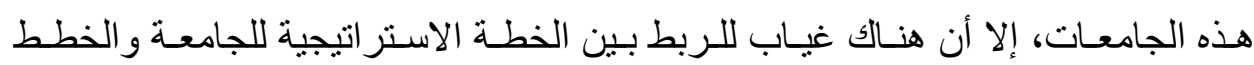
الاستر اتيجية للكليـات التابعـة لها وتحقيق التوافق المطلوب بينهمـا، وقصـور في قدرة وحدات التخطيط الاستر اتيجي على دعم ثقافـة التخطيط الاسـتر اتيجي داخل الجامعـات. مما يعني أن وحدات التخطيط الاستراتيجي التي أنشاتها تلك الجامعات لا تحقق الأهداف

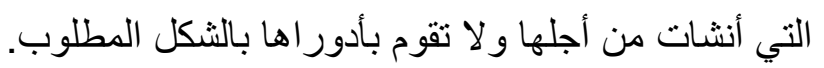

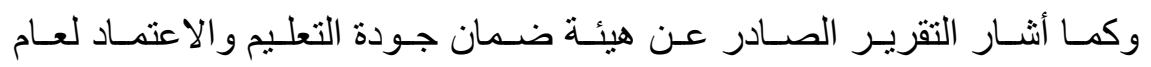

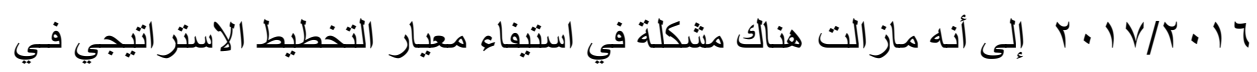

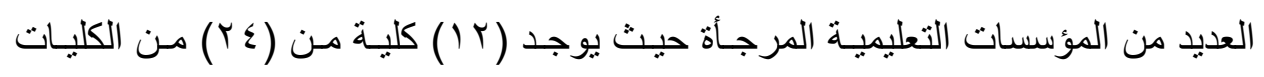

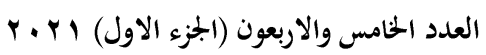

$$
\begin{aligned}
& \text { مجلة كلية التربية- جامعة عين شمس }
\end{aligned}
$$




\section{د/ وفـاء عبد الفتــاح محمـود}

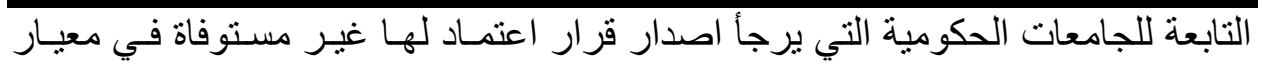

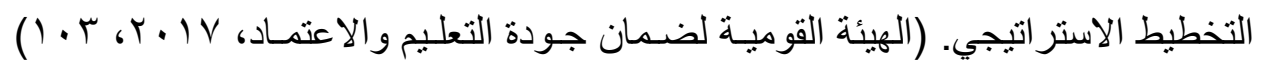
مما يعني ذلك أن فريق التخطيط الاستر اتيجي بالجامعـة والكليـات التابعـة لهـا لا يقوم بأدواره ومسئولياته المرجوة. " ويُعتبر التدريب خيـار إ إسـتر اتيجيا لأي جهـة تتطلع إلى إعداد كوادر بشـرية

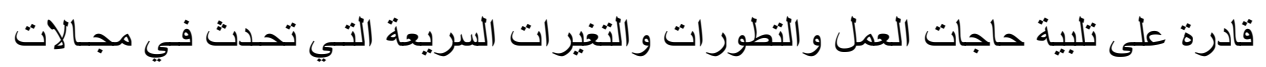

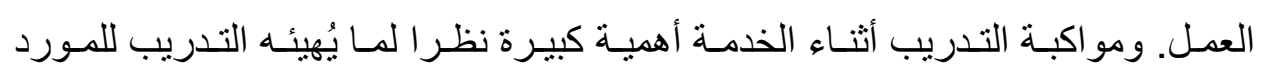

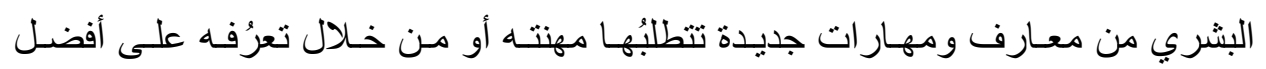

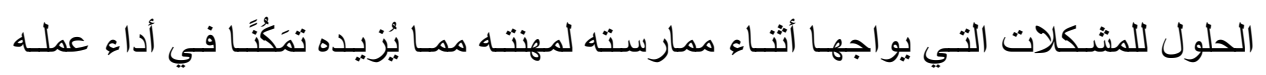

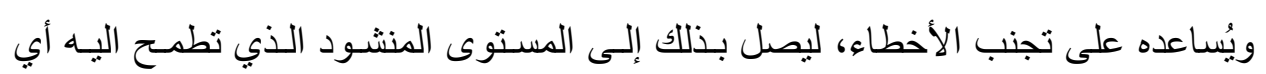

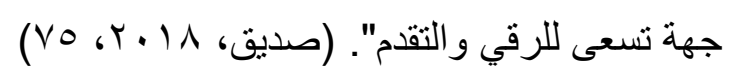

و أصبح التدريب من أهم العوامـل الفارقـة في استثمار الكوادر البشـرية لتصبح

أكثر معرفـة واستعدادًا وقدرة على أداء الأدوار و المهام المطلوبـة منهـا بكفــاءة عاليـة.

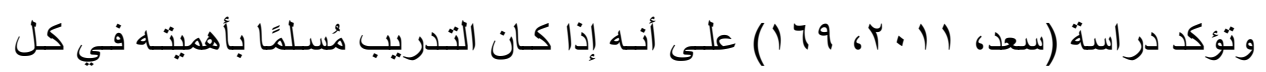

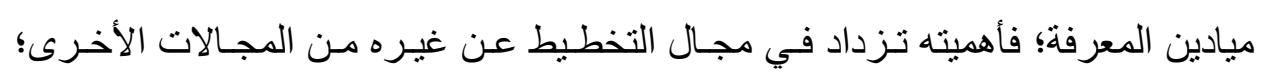

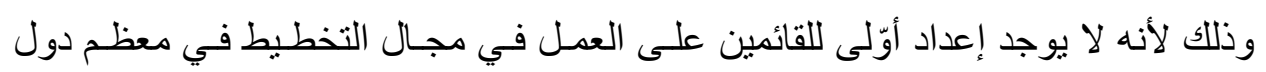

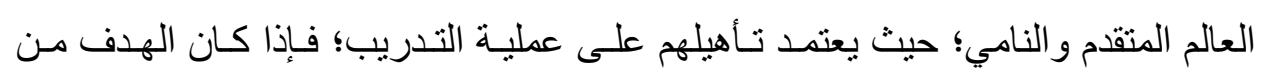

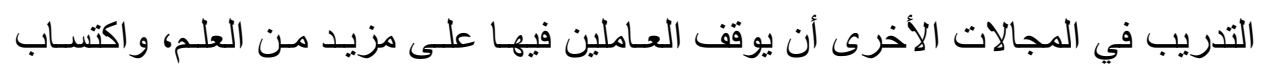

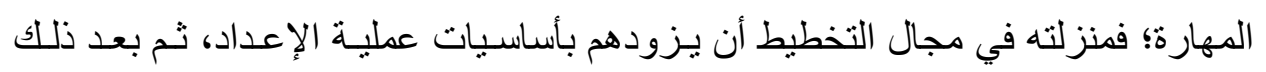

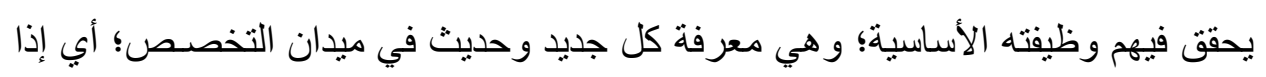
كان التدريب في غير التخطيط مجرد تجديد للخبرة؛ فهو في التخطيط اكسـاب الخبرة

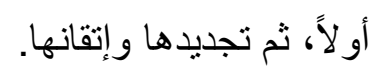




\section{استخدام أسلوب بيرت PERT في تخطيط برنامج لتدريب فرق التخطيط الاستراتيجي في الجامعات المصرية}

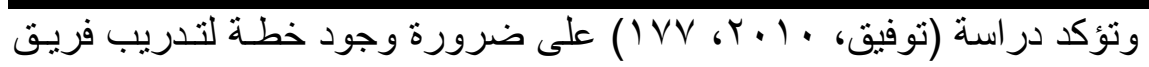

التخطبط الاسـتر اتيجي، و الهـدف مـن هـذه الخطـة تتميـة وتطـوير الكفايـات التخطيطيـة

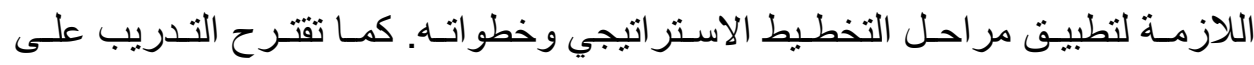
مهار ات التقيميم الذاتى للمؤسسـة، مهار ات التحليـل الاستر اتيجي، كيفيـة صـياغة رسـالة المؤسسة ورؤيتها، المهار ات البحثية و الإحصائية، مهار ات القياس و التقويم.

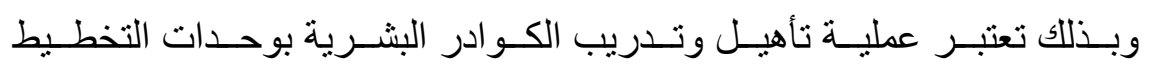
الاستر اتيجي في الجامعة وكلياتها- بحيث يتجهو ا بتخصصاتهم المختلفة نحو وجهة واحدة - خطوة مهمة لرفع أدائهم في إعداد الخطـة الاسـتر اتيجية ومتابعتها وتقويمها والإعداد للخطـة الجديـدة مـن خـلال تتميـة معسار فهم ومهـار اتهم و إتجاهـاتهم في مجـال التخطيط الاستر اتيجي. ويحتـاج التدريب تخطيطًا ناجحًا يتضـمن إعداد البـر امج التدريبيـة التـي يقرر تتفيذها ومتابعتها وتقويمها بهدف تتمية وتطوير الموارد البشرية في المؤسسة. ويمكن أن

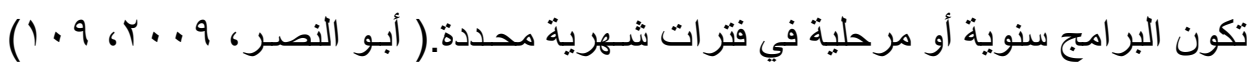

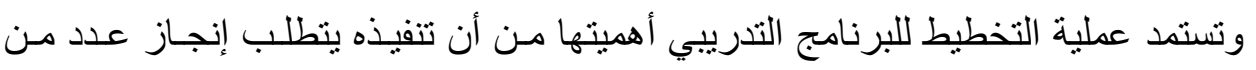
الأنشطة المتعاقبة والمتوازية في الفترة الزمنية المحددة له وفي حدود التكلفة المرصـوده لتنفيذه، ويعتبر أسلوب بيرت تقنية فعالة للتنفيذ الفعلى للبرنامج التدريبي بأقل وقت ممكن وبأقل تكلفة ممكنة وبأعلى كفاءة ممكنة. كما أنه يتعرف على التعارضـات ببين الأنشطة المختلفة والتنسيق بينها حتى يمكن العمل في الوقت المحدد دون تـأخير، وكذللك قدرتـه على توصيل المعلومات اللازمة لإدارة البرنامج عن سير تتفيذ البرنـامج و العقبـات التي

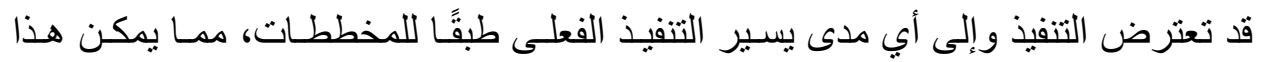
الإدارة من اتخاذ الإجـر اءات التصـيحية التي تؤودي إلى تـذليل العقبـات التي تعترض

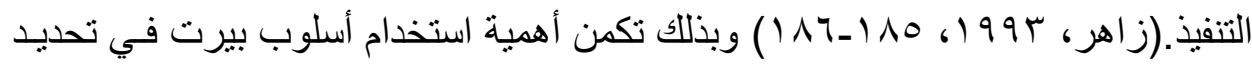

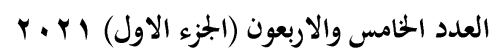

مجلة كلية التربية- جامعة عين شمس 


\section{د/ وفــاء عبد الفتــاح محمـود}

وتحليل الأنشطة الأساسية للبرنامج التدريبي وترتيبها، و التي يلزم تنفيذها لضـمان تحقيق هذا البرنامج أهدافه المرجوة بأقل قدر ممكن من الزمن.

\section{مشكلة البحث:}

بناء على مـا تقدم، تعـاني وحدات التخطبط الاسـتر اتيجي بالجامعـات المصـرية

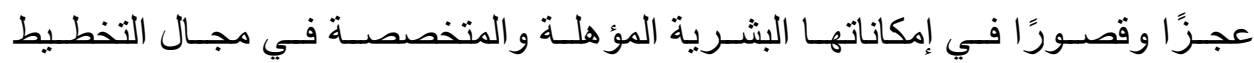
الاسـتر اتيجي وذلك مـن منطلق أن التخطيط الاسـتر اتيجي ليس دراسـة أكاديميـة، ويـتم تكليف الموارد البشرية بالعمل في الوحدات دون إعداد مسبق يتفق مـع منهجيـة التخطيط يسهم في اكسابهم مفاهيم التخطيط ومداخله و أساليبه و أدو اته، أو حتى دون تدريب تـأهيلي

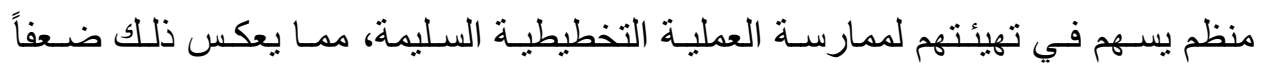
و اضحاً في الكفايات التخطيطية لاى فريق التخطيط الاستر اتيجي. ولكى تؤدى وحدات التخطيط الاسـتر اتيجي المهام المنوطـة بهـا والأدوار و المسئوليات المتوقعـة منهـا؛ فإنسه ينبغي أن يتو افر لدى الفريق القائم بالتخطيط مجموعة من الكفايات التي تمكنه مـن ذلك؛ فعمليـة التخطيط تحتـاج إلى كثير مـن الكفايـات الفنيـة والإداريـة و البحتيـة والإحصــائية و التقنية أي أنها تحتاج إلى متخصصين ومؤهلين، وتحتاج أيضًا إلى القدرة على الإبتكـار

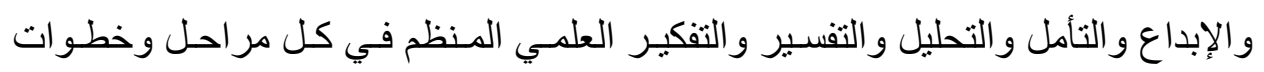
التخطيط الاستر اتيجي. وليس تمة شك أن التدريب وسيلة فعالـة لتتميـة وتطوير الكفايـات

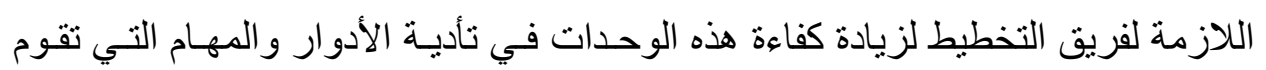

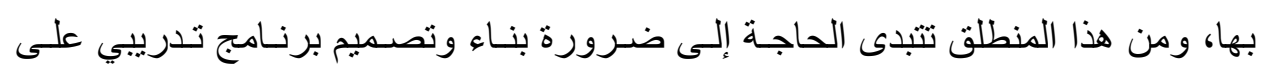

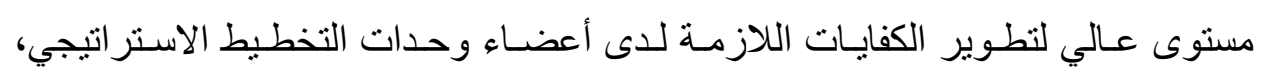
ويكون تركيزه بشكل أساسي على مختلف جو انب العمليـة التخطيطيـة، ولكي يحقق هذاء

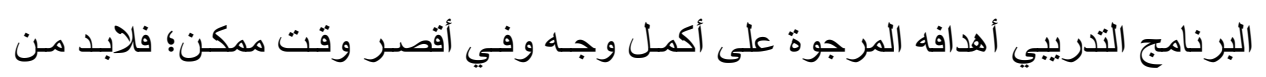
التخطيط لتنفيذ أنشطة التدريب وفق أسلوب تخطيطي علمي. 
استخدام أسلوب بيرت PERT في تخطيط برنامج لتدريب فرق التخطيط الاستراتيجي في الجامعات المصرية

\section{في ضوء ذلك تحددت مشكلة البحث في السؤال الرئيس الآتي:}

كيف السبيل نحو التخطيط لبرنامج تدريب فرق التخطيط الاسنر اتيجي في الجامعات

$$
\text { المصرية باستخدام }
$$

$$
\text { أسلوب بيرت PERT }
$$

ويتفرع من هذا السؤال عدة أسئلة فرعية تتمثل فيما يأتي:

• ما الإطار الفكري حول فرق التخطيط الاستر اتيجي في الجامعات؟

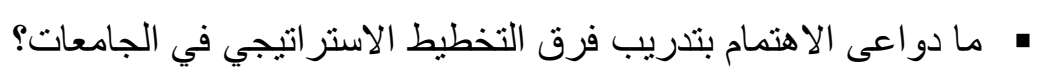

• ما الكفايات التي يحتاج فريق التخطيط الاستر اتيجي التدريب عليها؟

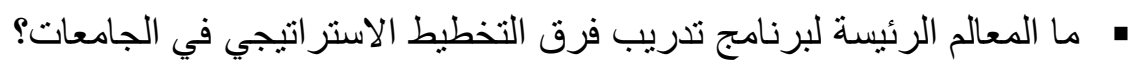

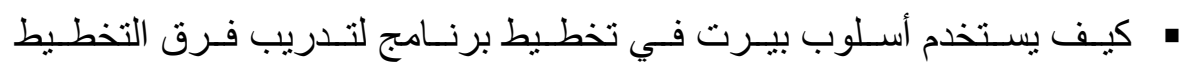

$$
\text { الاستر اتيجي؟ }
$$

• ما الخطة المقترحة لتدريب فرق التخطيط الاستر اتيجي في الجامعـات باستخدام

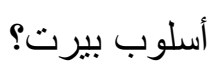

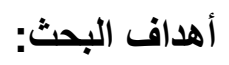

يهرف البحث إلى التخطيط لبرنـامج تدريبي لتطوير الكفايـات التخطيطية لـى فرق التخطيط الاستراتيجي بالجامعات المصرية باستخدام أسـلوب بيرت، وقد استلزم ذلك السعى نحو تحقيق مجموعة من الأهداف الفرعية الآتية: تحديد كيفية بناء فريق التخطيط الاستر اتيجي في الجامعـة و الكليـات التابعـة لهـا،

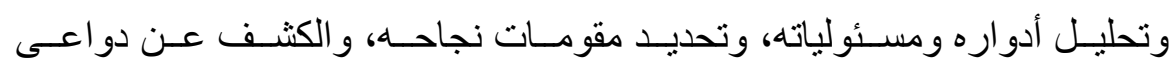

$$
\text { ومبرر ات الاهتمام بتدريبه. }
$$

تحديــ الكفايـات الأساسـية اللازمـة لفريـق التخطبط الاسـتر اتيجي للقبـام بـالأدوار

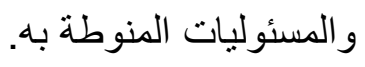

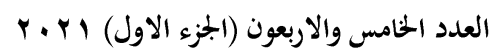

مجلة كلية التربية- جامعة عين شمس 
• التوصل إلى قائمة الكفايات التخطيطية التي يحتاج الفريق التدريب عليها وذلك في وي ضوء تحليل أدواره ومسئولياته في عملية التخطيط الاستراتيجي. تحليل العناصر الرئيسة لمنظومة التدريب، وبيـان أهـم عو امـل نجـاح التدريب في تطوير الكفايات لدى الفريق القائم بالتخطيط الاستر اتيجي. تصميم برنامج تـدريبي مبنـي على الكفايـات التخطيطيـة اللازمـة لفريـق التخطيط الاستر اتيجي. توضيح كيفية استخدام أسلوب بيرت في تخطيط وبرمجـة أزمنـة أنشـة البرنـامج

$$
\text { التذريبي. }
$$

اقتـر اح خطـة لتنفيذ برنـامج تـدريب فريـق التخطيط الاسـتر اتيجي تحقيقًا لأهدافـه

$$
\text { المرجوة في أقصر وقت ممكن. }
$$

\section{تتضح أهمية البحث فيما يلي:}

تتبثق أهمية البحث من أهمية تطبيق التخطيط الاسـتر اتيجي في الجامعـات المصـرية الحكوميـة؛ فـالتخطيط الاسـتر اتيجي يسـاعد على تعزيز قدرة الجامعـة على العمـل و التعلم بشكل استر اتيجي، وتحسين أداء الجامعة وتعزيز مهمتهـا واسـتجابتها بفعاليـة

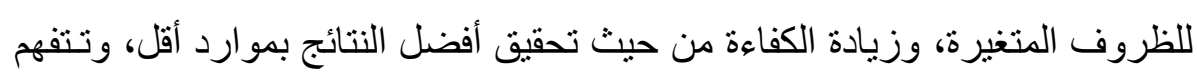
الجامعة وضعها بشكل أكثر وضوحًا وهي قادرة على إعادة تصـور موققها و عملها و إنشاء إطار عمل تفسيري يمكن أن بوجه تطوير الاستر اتيجية وتتفيذها، ويتتم اتخـاذ قرارات اليوم في ضوء عو اقبها المستقبلية، وتعزيز القدرات التتظيمية حيـث تحسـين

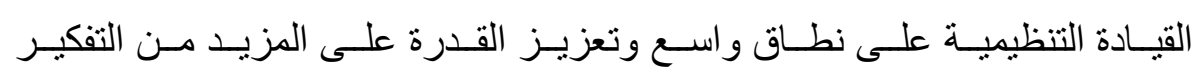
الاسـتر اتيجي و العمـل و التتعلم، وتحسـين الاتصــالات و العلاقـات العامـة حيـث بـتم توصيل الرسالة والرؤية والأهداف والاستر اتيجيات وبر امج العمل بشكل أكثر فعاليـة 
استخلام أسلوب بيرت PERT في تخطيط برنامج لتدريب فرق التخطيط الاستراتيجي في الجامعات المصرية فيطاية

لأصحاب المصلحة الرئيسيين ويتم إنثـاء الصـورة المرغوبـة للمؤسسـة وإدارتها.

(Bryson \& Alston,2005, 9-12)

يفيد البحث فرق التخطيط الاستراتيجي بالجامعات؛ حيث يؤكد على ضرورة مر اعـاة

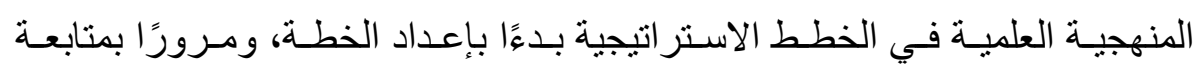

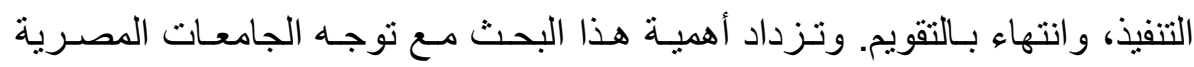
للحصول على الاعتماد الأكاديمي من الهيئة القومية لضمان جودة التعليم والاعتمـاد، إذ إن وجود خطة استر اتيجية سـليمة للجامعـة والكليـات التابعـة لهـا أحد المتطلبـات الأساسية للتقدم للاعتماد.

يكتسب البحث أهميته من كونه يقترح برنـامج تدريبي لتطوير الكفايـات التخطيطية

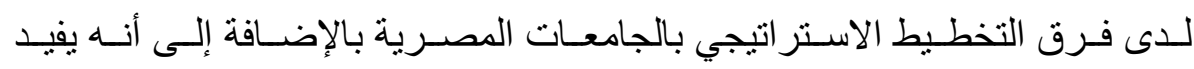

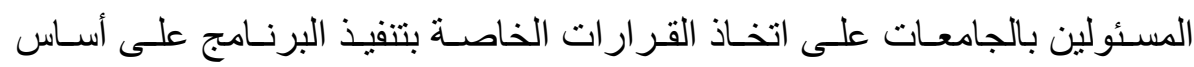
أسلوب علمي يفرض نوع من الرقابة والمتابعة إلى حد ما على أزمنـة تنفيذ أنشطة هذا البرنامج حتى ينم تتفيذه وتحقيقه لأهدافه المرجوة في أقل وقت ممكن.

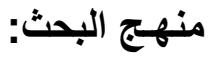

تقتضي طبيعة البحث وأهدافه استخدام المناهج والأساليب الآتية:

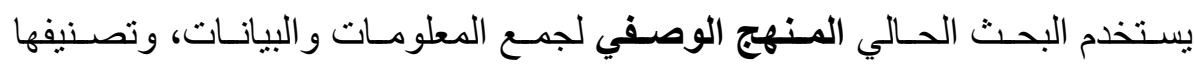
ومعالجتها وتحليلها تحليلاً كافيًا ودقيقًا لاستخلاص دلالتها عن الإطار الفكري حول

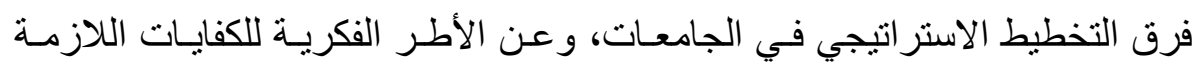
لفريـق التخطيط الاسـتر اتيجي والتـدريب المبنـي عليهـا، وصـو لاً لتصـميم برنـامج تـدريبي مبنـي على الكفايـات التخطيطيـة اللازمـة لفريـق التخطـيط الاسـتراتيجي لتطوير ها، وكذلك رصد أساسيات تطبيق أسلوب بيرت في تخطبط البرامج أو المشرو عات. - ات

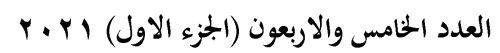

(196)
مجلة كلية التربية- جامعة عين شمس 


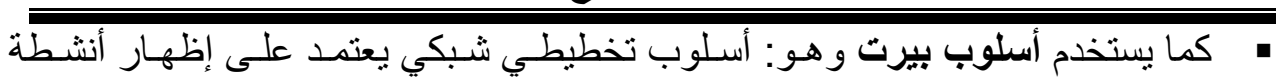

و عمليات المشروعات و البر امج في شكل شبكة توضـح العلاقـات المتداخلـة بينهـا تبعًا لمعايير الزمن و التكلفة على نحو بضع بـدائل متعددة ومحسـوبة مسـتقبليًا على ضـوء هذه المعايير. و هو أسلوب شبكي احتمالى لتقويم ومتابعة تتفيذ المشـرو عات و البر امج.

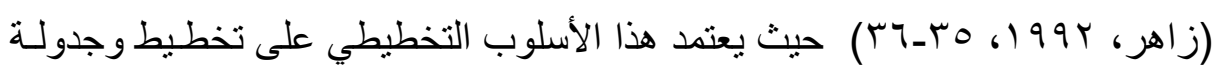
مشروع أو برنامج يحوي مجموعة من الأنشـطة المختلفـة باسـتخدام تقدير ات الوقت المتفائلة و المحتملة و المنشائمة لكل نشاط، ورسم المخطط الثبكي لهـا، و إعداد جدولـة زمنية لأوقات البدء والانتهاء لكل نشاط بهدف تحديد المسار الحـرج أي تحديد الـزمن

الكلي لإتمام تنفيذ المشروع أو البرنامج. (Rand, 2001, 649) ويستخدم البحث الحالي أسلوب بيزث/ الوقت لتخطبط و إدارة برنامج تدربب فرق التخطيط بالجامعات المصرية لكى يتم تنفيذه وتحقيق أهدافه المرجوة في أقل وقت ممكن وبأعلى كفاءة ممكنة، حيث يحدد أهداف البرنامج و أنشـته وترتيبهـا بشـكل منطقي وبنـاء المخطط الثبكي لها، يحدد تقديرات الزمن المتفائل والأكثر احتمالاً والمتشائم لكل نشاط ثم ودئ يحدد الزمن الممكن لتنفيذ كل نشاط ويحدد الزمن المبكر و المتأخر للبدء والانتهاء من تتفيذ كل نشاط ومن ثم يحدد الأنشطة الحرجة التي لا يمكن حدوث تأخير في تنفيذها حتى يمكن لإدارة البرنامج الاستعداد لها مقدمًا ويحدد مقدار الزمن الفائض في الأنشطة غير الحرجـة مما بساعد الإدارة على الاستفادة منه في تأخير تنفيذ أي نشـاط غير حـرج إذا لـزم الأمـر، ويحدد الزمن اللازم لإنجاز البرنامج التدريبي ككل وهـو زمـن أطول مسـار حـرج على المخطط الثبكي، وأخيرًا توقع عددًا من احتمالات تنفيذ البرنامج التدريبي. وقد قامت الباحثة بـإجر اء مقـابلات شخصـية مـع بعض أعضـاء هيئة التدريس الذين لديهح دراية بالأنشطة و العمليات التفصيلية للبر امج التدريبية لاستطلاع آرائهم حول أنشطة البرنامج التدريبي المقترح وترثيبها منطقيًا لتتسلسل أحداثها حسب طبيعة تنفيذها، و الزمن ( المتفائل، الأكثر احتمالاً، المتشائم) اللازم لتنفيذ كل نشاط على حده.

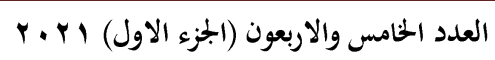

مجلة كلية التربية- جامعة عين شمس 


\section{استخدام أسلوب بيرت PERT في تخطيط برنامج لتدربب فرق التخطيط الاستراتيجي في الجامعات المصرية فيطاية}

مصطلحات البحث:

يتضمن البحث المصطلحات الآتية:

Planning : •

يعـرف التخطـيط بأنـه: التوقـع الفكـري للمو اقـف المسـتقبلية المحتملــة واختيـار

المو اقف المرغوبة التي يجب تحقبقها (الأهداف) وتحديد الإجـراءات التي يجب اتخاذهـا لبلوغ هذه الأهداف بتكلفة معقولة. وبعبارة أخرى، يتضمن التخطيط التفكير في المستقبل

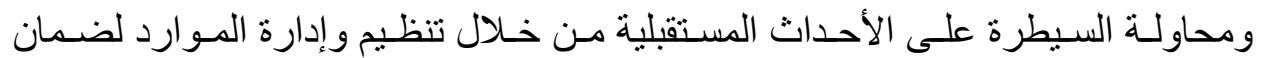
تحقيق الأهداف المحددة بنجاح. Unesco(A), 2010, 9) كما يعرف التخطيط بأنه: عملية علمية تتضمن تحديد الأهداف وتحديد الإجر اءات مـع تحديد وتخصيص المـوارد المطلوبة والجداول الزمنية لتحقيق هذه الأهداف. (Malik, et. al, 2011, 3)

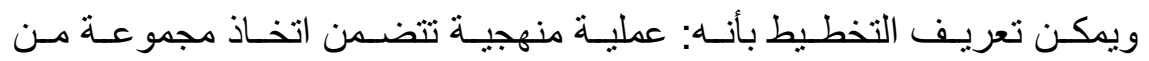
الإجر اءات المنظمة لتحقيق أهداف محددة مسبقًا في ضـوء الاستخدام الأمثل للمـوارد البشرية و المالية و المادية الممكنة و إطار زمني ممكن.

\section{" التدريب: Training}

يعرف التدريب بأنه: عمليـة منظمـة مستمرة محور هـا الفرد تهـدف إلى إحـداث تغيير ات محددة سلوكية وفنية وذهنيـة لمقابلـة احتياجـات حاليـة ومستقبلية يتطلبهـا الفـرد و العمل الذي يؤديه و المؤسسة التي يعمل بها. كمــا يعد التـدريب أيضًا نشـاط مخطط لـهـ و إجر اءات منظمة تهدف إلى إحداث تغيرات في الفـرد مـن ناحيـة المعـارف والمهار ات و الخبرات ومعدلات الأداء وطرق العمل و السلوك و الإتجاهات بما يجعل الفرد قادر على

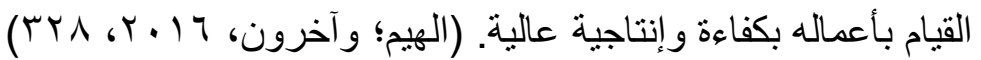
ويمكن تعريف التدريب المبني على الكفايـات التخطيطيـة بأنـه: أحـد أهـ أنمـاط التدريب التـي تتطـوى على أنشطة و عمليـات منظمـة ومخططسة تستهدف تحقيق النمـو 


\section{د/ وفـاء عبد القتــاح محمـود}

المهنـي لـدى فريـق التخطـيط الاسـتر اتيجي مسن خـلال اكسـابه المعسارف و المهـار ات و الإتجاهـات اللازمـة لعمليـة التخطبط و التـي تسـاهم في رفع مسـتوى أدائسه في مجـال التخطيط الاستر اتيجي.

\section{التخطيط الاستراتيجي:Strategic Planning}

يعرف التخطيط الاستراتيجي في مجـال التعليم بأنسه: تخطيط يتحرك في أفق

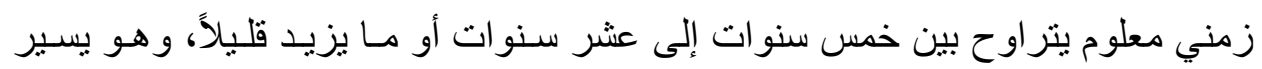

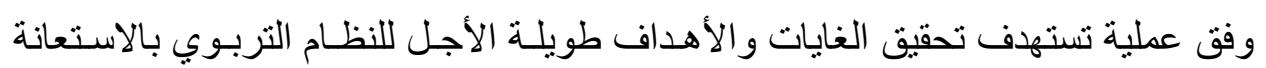

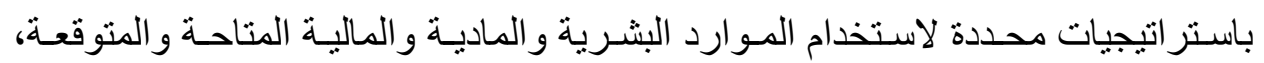
وينتهي بخطة استراتيجية تتضـمن عددًا مـن الخطط التنفيذيـة ويكون لكل هذه الخطط

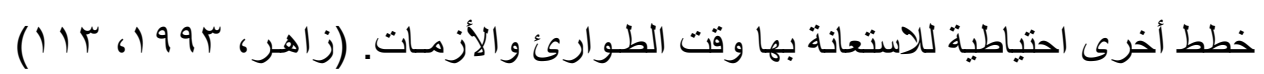
كما يعرف التخطيط الاستراتيجي في مجال التعليم على أنه: منهج نظامى يستشرف آفاق

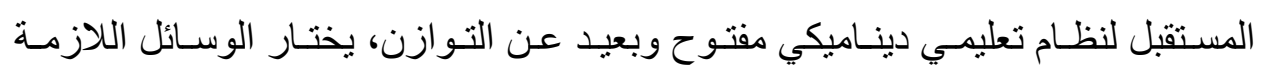

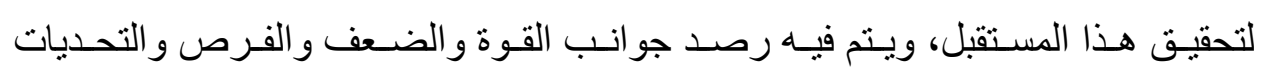

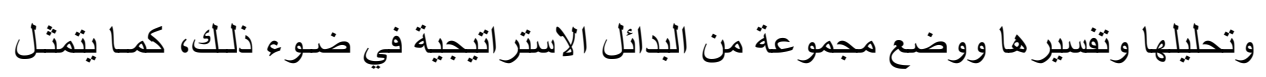

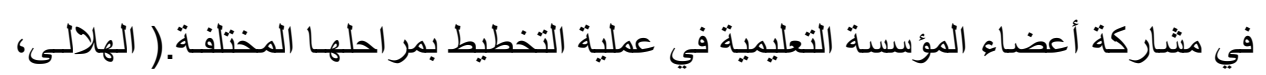

$$
(0) 06.99
$$

ويمكـن تعريــ التخطسيط الاسـتر اتيجي للمؤسسـة التعليميـة بأنسه مـنهج علمـي

لاستشر اف آفـاق مستقبلية تربويـة؛ فهو عمليـة منهجيـة يتم مـن خلالهـا تحديد الرسـالة و الرؤية والغايات و الأهداف الاستر اتيجية للمؤسسة مـع مر اعـاة البيئة المحيطـة الداخليـة و الخارجيـة لتحديـد نقـاط قوتهـا وضـفهها و الفرص التـي يمكن الإفـادة منهـا و التحديات

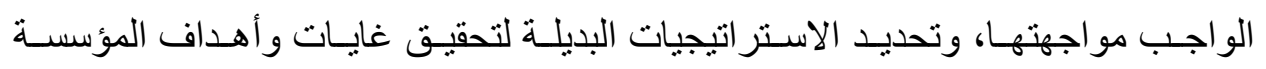

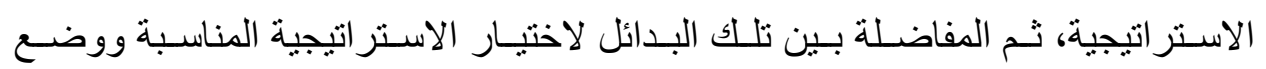
الإجر اءات المخططة بشأن تنفيذها ومتابعتها وتقويمها.

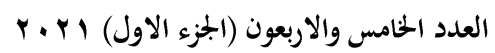

مجلة كلية التربية- جامعة عين شمس 
استخدام أسلوب بيرت PERT في تخطيط برنامج لتدريب فرق التخطيط الاستراتيجي في الجامعات المصرية فيطاية

خطوات السبر في البحث:

يسير البحث الحالي وفقًًا للخطوات التالية:

الخطوة الأولى: يتم من خلالها عرض وتحليل الإطار الفكري حـول فرق التخطيط

$$
\text { الاستر اتيجي في الجامعات. }
$$

الخطوة الثانية: يتم مـن خلالهـا وضــع قائمــة الكفايـات التـي يحتـاج فريق التخطيط التدريب عليها، وتحليل لمنظومة التدريب من حيث مدخلاته و عملياته ومخرجاته.

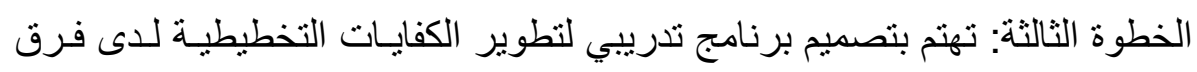

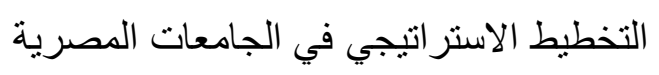

الخطوة الرابعة: يتم من خلالها اقتـر اح خطـة لتنفيذ برنـامج تـدريب فرق التخطيط

$$
\text { الاستر اتيجي بالجامعات باستخدام أسلوب بيرت. لئ. }
$$

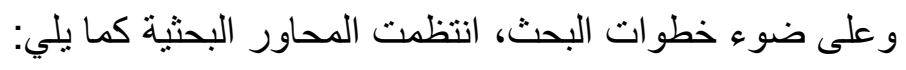

المحور الأول: الإطار الفكري لفرق التخطيط الاستراتيجي في الجامعات:

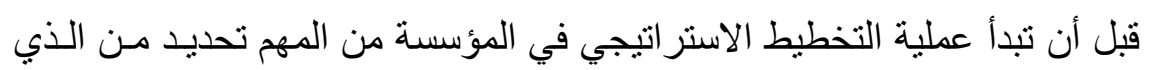

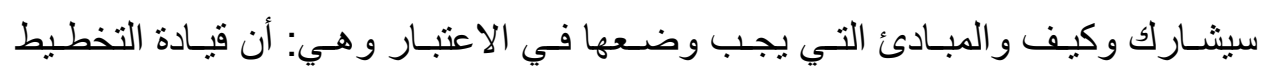
الاستر اتيجي يجب أن تأتي من الإدارة العليا، ومشاركة الفئات الرئيسة للمؤسسـة بطريقة وفئة

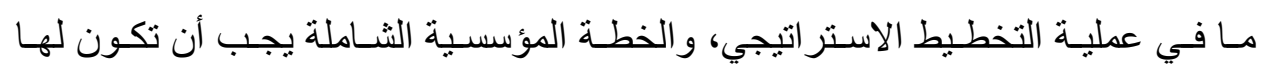
الأسبقية وأن تعطي نوجيهات لخطط الوحدات الفرعيـة. (Luxton, 2005, 11-12)

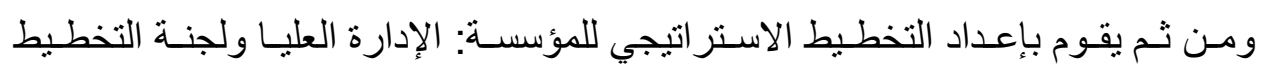

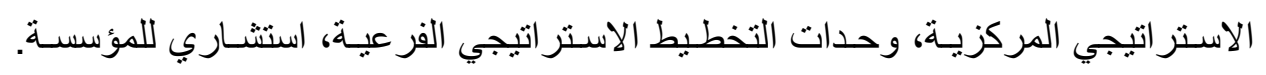

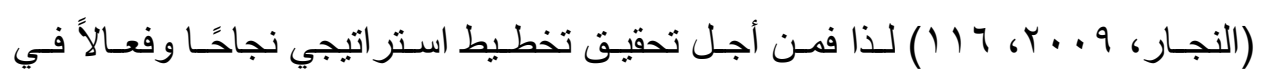

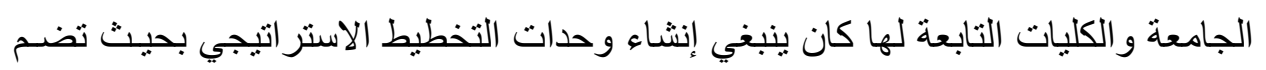




\section{د/ وفــاء عبد الفتــاح محمـود}

فريق عمل لديه معارف ومهار ات وقدرات للنهوض بعملية التخطيط الاستر اتيجي على وفي لفي مستوى الجامعة. ويمكن توضيح الإطار الفكري على النحو التالي: أولاً: ماهية بناء فرق التخطيط الاستراتيجي في الجامعات:

يتم تشكيل الفريق الاستر اتيجي برئاسة رئيس المؤسسـة وأعضـاء يمثلـون الإدارة العليا وكذلك أعضاء من الإدارة الوسطى والإدارة التشغيلية بحيث يكون هؤلاء ممثلين

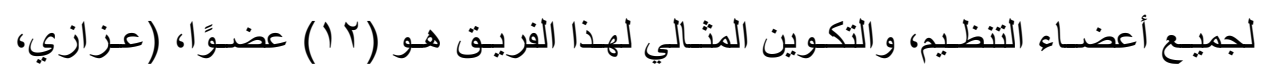

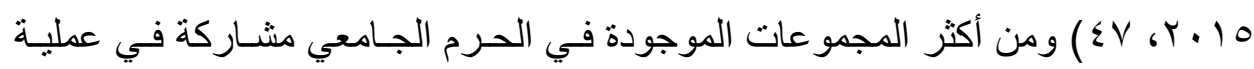
التخطيط هي: الإدارة العليا وأعضاء هيئة التدريس والموظفين، والطلاب أيضًا يكون لهم دور نشط في عملية التخطيط بينما غالبًا ما يكون هناك نقص في الاستمر ارية في تمثيل

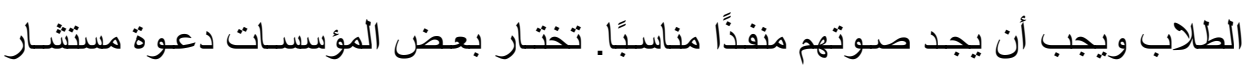
خـارجي لمسـاعدتها في عمليـة التخطيط، ومـن الضــروري أن يكون الفـرد أو الأفراد

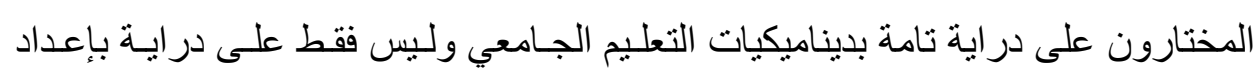
الخطة الاستر اتيجية. (Luxton, 2005,12)

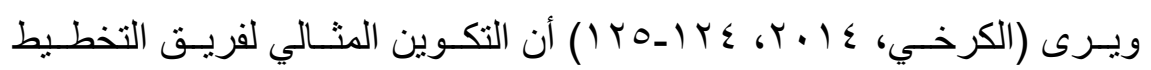

الاستر اتيجي هو من (9-1 (1) بحيث يضم شرائح مختلفة من المؤسسة منها من لـه درايـة بالتخطيط الاستر اتيجي، أخصائي في الأمور الماليـة، أخصـائي تقديم الخدمات، موظف هن متخصص بالمو ارد البشرية، متخصص في الكمبيوتر و البرمجيـات. و إثـر الك القيـادات الإدارية في عملية التخطيط الاستر اتيجي أمـر ضـروري حيث إنهم المسـتوى التنفيذي، و إذا كان البعض منهم لا يمكن أن تكون له مشاركة فعلية فيمكن تبادل المسـودات الأولى لهى لهري من الخطة الاستر اتيجية معهم و الحصول على ملاحظاتهم وبذلك يمكن ضـمان الحصـول على مجمو عة متنو عة من وجهات النظر.

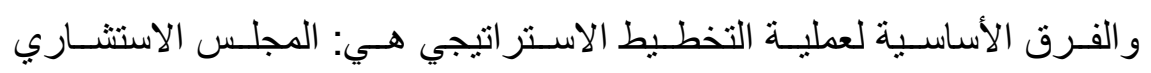

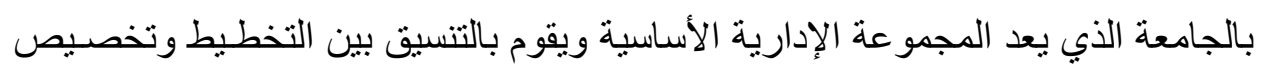

$$
\begin{aligned}
& \text { العدد الحامس والاربعون (الجزء الاول) ب. r. T } \\
& \text { (201) } \\
& \text { مجلة كلية التربية- جامعة عين شمس }
\end{aligned}
$$


استخدام أسلوب بيرت PERT في تخطيط برنامج لتدريب فرق التخطيط الاستراتيجي في الجامعات المصرية

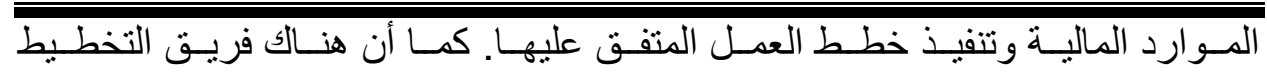
الاستر اتيجي الذي يتألف من (9 ـ0 1 ) عضوًا مـن بينهم ممثلون عن الهيئة التدريسية و الموظفون والطـلاب بالإضـافة إلى علافـة عضـوية وطيدة مـع المجلس الاستشـاري،

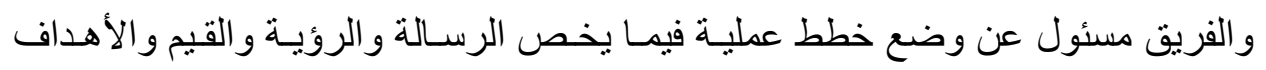

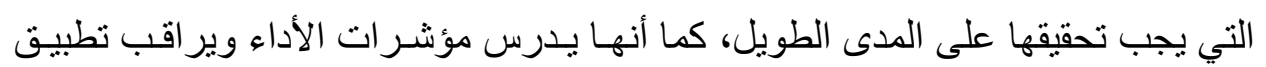

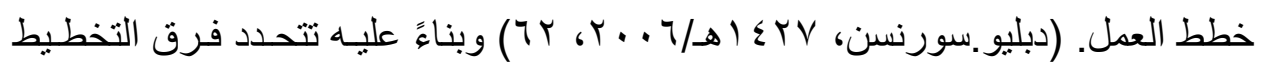
الاستر اتيجي في:

1- فريق التخطيط الاستراتيجي على مستوى الجامعة: يشـكل مجلس إدارة الوحدة المركزيـة للتخطيط الاسـتر اتيجي في الجامعـة مـن

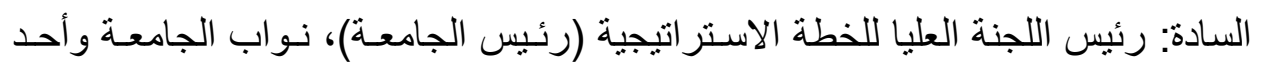
مستشـاري رئسيس الجامعـة، المدير التنفيذي للوحدة المركزيـة للتخطيط الاسـتر اتيجي،

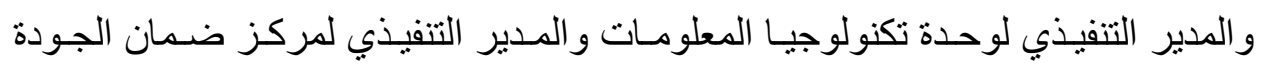
و المدير التففيذي لوحدة إدارة المشروعات، ثناثة أو أكثر من الخبراء في مجـال التخطيط الاستر اتيجي بالإضـافة للخبرة العمليـة بالمشـاركة في إعداد خطط اسـتر اتيجية سـابقة.

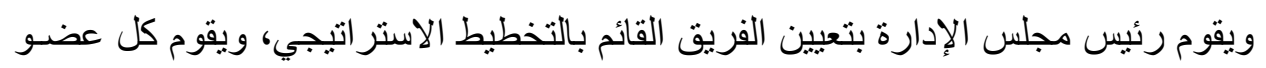
من أعضاء فريق التخطيط بتشكيل فريق عمل برئاسته للقيام بالمهام التي توكل إليـه فيمـا يخص الخطة الاستر اتيجية للجامعة. و تحتاج المؤسسة إلى الفريق القائم بالتخطيط في وحدة التخطبط المركزيـة لقيـادة

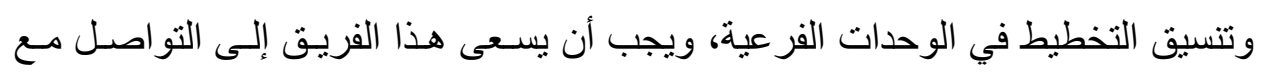

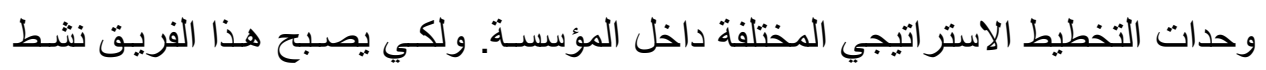

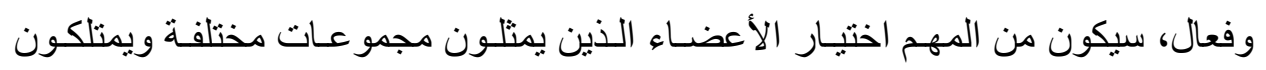

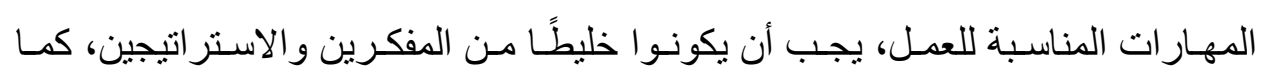

$$
\begin{aligned}
& \text { العدد الحامس والاربعون (الجزء الاول) ب. r. T } \\
& \text { مجلة كلية التربية- جامعة عين شمس }
\end{aligned}
$$




\section{دا وفــاء عبد الفتــاح محمـود}

يحتاج هذا الفريق إلى تضمين الأفر اد الذين يمكنهم إبقاء المجموعة على درايـة بالجو انب دولب

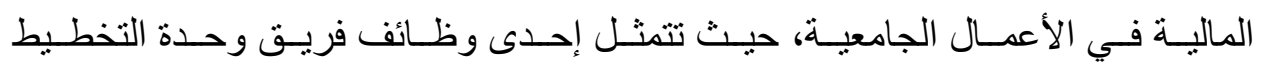
الاستر اتيجي المركزيـة في تحديد الإتجاهـات الرئيسـة للاسـتر اتيجية المؤسسبة لضــــان تطوير خطة مالية لتسهيل عملية التخطيط الاستراتيجي النشاملة، ويطلب الفريق المركزي من الوحدات الفرعية بالمؤسسـة العمل على جو انب مختلفـة مـن الخطـة وتقديم تقـارير

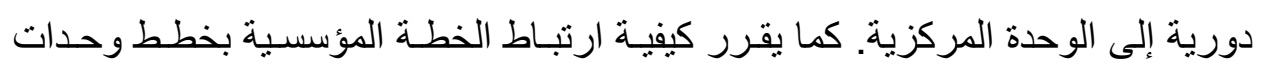

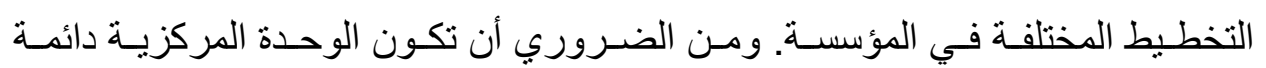
مستمرة وتتلقى معلومات محدثة من مختلف الوحدات الفرعية ونوصسي بـإجر اء تغييرات في الخطـة الاستر اتيجية. (Luxton, 2005, 13) ويتم تشكيل فريق متابعـة الخطـة التنفيذية للخطة الاستر اتيجية على مستوى الجامعة على أن يضم هذا الفريق بين أفر اده الهاه الفريق القائم بالتخطيط بالوحدة المركزية للتخطيط الاستر اتيجي بأكمله. r- فرق التخطيط الاستراتيجي على مستوى الكليات:

يشكل مجلس إدارة وحدة التخطبط الاستر اتيجي بالكلية من السادة: رئيس مجلس فيس

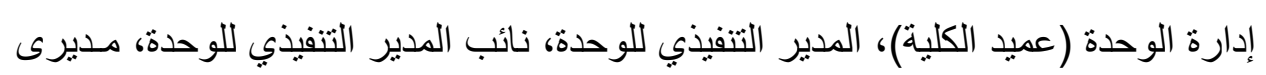
الإدارات الوظيفية، رؤسـاء الأقسـام التنفيذيـة، عدد مـن أعضـاء هيئـة التـدريس بالكليـة. ويقوم كل عضو من أعضـاء فريـق الوحدة بتشـكيل فريق عمل برئاستها لتنفيذ المهام المتعلقة بالغاية التي ير أسها. ويتم تشكيل فريق متابعة الخطة التنفيذية للخطة الاستراتيجية على مستوى الكليـة من: رئيس الفريق(العميد بصفته الوظيفية لا بشخصه)، وكلاء الكلية ( بصفتهم الوظيفيـة

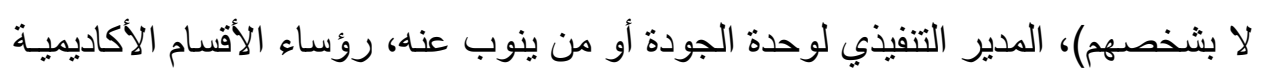

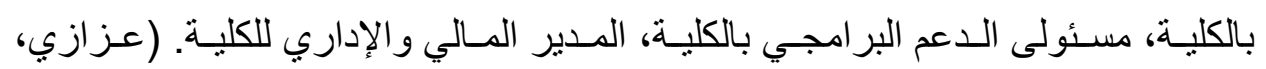

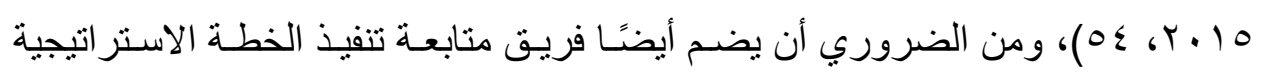




\section{استخدام أسلوب بيرت PERT في تخطيط برنامج لتدربب فرق التخطيط الاستراتيجي في الجامعات المصرية}

بالكلية بين أفراده الفريق القائم بالتخطيط الاستر اتيجي بالكلية بأكمله. ويلزم الأمـر تحديد أدوار ومسئوليات الفرق الأساسية للتخطبط الاستر اتيجي تحديدًا دقيقًا. وتتحـد إختصاصــات رئسيس مجلـس الإدارة فـي وحـدة التخطيط الاســتراتيجي

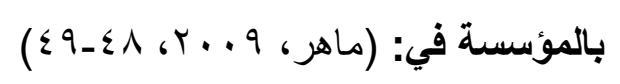

أ- أن يتبنى مجهودات التخطبط، ويعمل على حث الجميع على المشاركة الإيجابية.

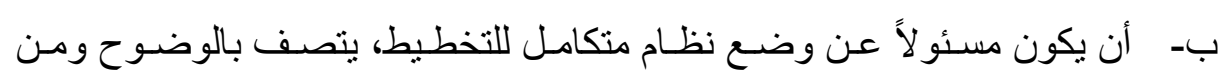
السهل فهمه، وتوزيع أعباء المسئوليات على الفريق القائم بالتخطيط. ج- ينقل اقتراحات الأطر اف المستفيدة مـن المؤسسـة إلى مدير التخطيط للاستفادة منها عند وضع الاسنر اتيجيات. د- قيادة المناقثـات و عقد الاجتماعـات الخاصـة بتحديد الغايـات و الأهداف ورسـالة المؤسسة و الاستر اتيجيات. هـ إصدار القرارات بإعداد الخطابات للبدء في خطوات التخطبط الاستر اتيجي مـع أعضاء مجلس الإدارة. و - تعيين الفريق القائم بالتخطيط الاستر اتيجي للمؤسسة. ز - أن يقوم بمناقثة وتعديل و الموافقة على الخطة الاستر اتيجية للمؤسسة. ح- توقيع العقاب على أي تقصير أو إهمال في تنفيذ الخطط في المستويات التنفيذية.

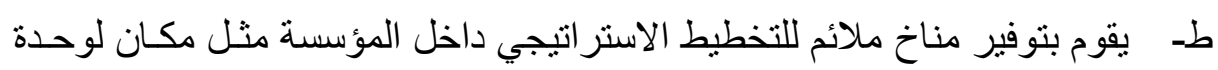
التخطيط الاستر اتيجي و التجهيزات اللازمة. ي- تلقى تقارير دورية عن درجة التقدم في تنفيذ الخطط الاستر اتيجية. وتتحدد إختصاصات مدير وحدة التخطيط الاستراتيجي بالمؤسسة في: (ماهر ، 9 ـ. . ץ، 10)

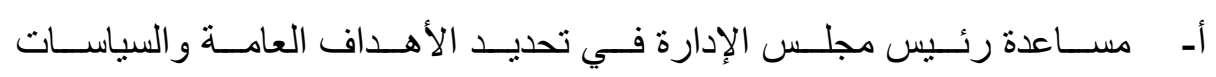
و الاستر اتيجيات الخاصة بالمؤسسة.

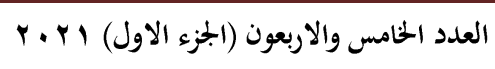

(204)

مجلة كلية التربية- جامعة عين شمس 


\section{د/ وفــاء عبد القتــاح محمـود}

ب- تقديم النصح و المعونة لكل الإدارات بالمؤسسة بخصوص وفئ الخطة الاستر اتيجية.

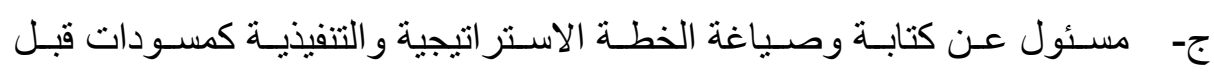
عرضها على رئبس المؤسسة. د- تحديد الأدلة و اللوائح المنظمة لخطوات الخطط المختلفة بالمؤسسة وعمل وتنفيذ الدر اسات و البحوث الخاصة بالخطة. هـ - تدريب الفريق القائم بالتخطيط الاستر اتيجي. و - اختبار وتطبيق أحدث الأساليب الفنية في التخطيط. ز- متابعة تتفيذ الخطة وتحديد انحر افات التنفيذ عن معايير الخطة.

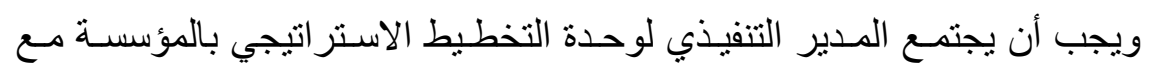

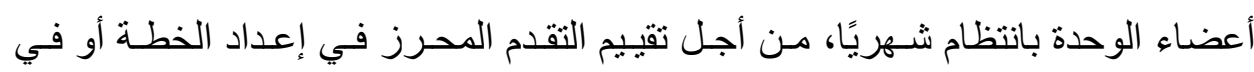

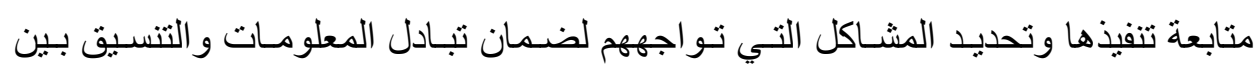
مجمو عات العمل المختلفة، والتداول بشكل جمـاعي القرارات الفنيـة التي يجب اتخـاذهـا للحفاظ على عملية التخطيط الاستر اتيجي في الطريق الصحيح. ثانيًا: أدوار ومسئوليات الفريق القائم بالتخطيط الاستر اتيجي:

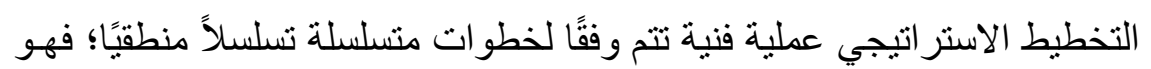

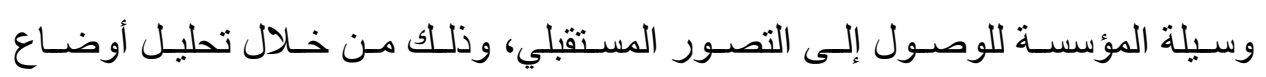

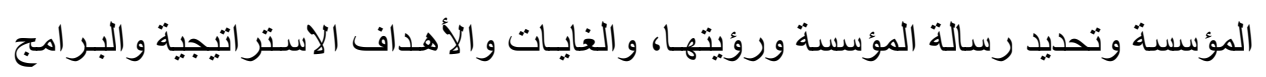

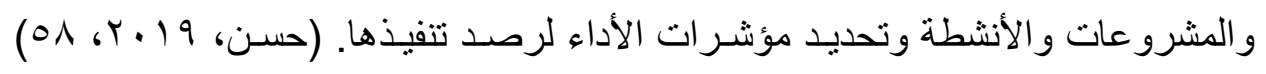

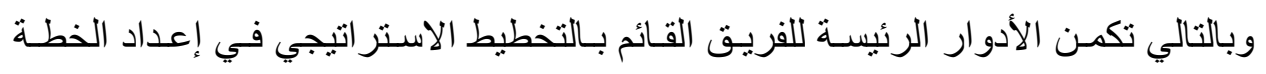

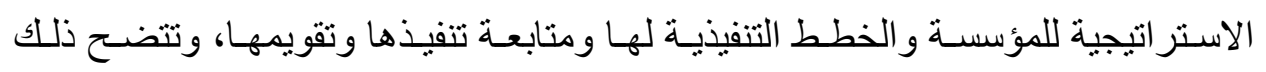
بالتفصيل فيما يلي: 
استخدام أسلوب بيرت PERT في تخطيط برنامج لتدريب فرق التخطيط الاستراتيجي في الجامعات المصرية فيطاية

1- إعداد الخطة الاستراتيجية:

يعد إعداد خطة استر اتيجية للمرة الأولى عملية تشاركية يقوم بها فريتق التخطيط الاستر اتيجي في المؤسسة، وتستغرق وقتًا ما بين ^ إلى ب ا شهرًا. ويمكن تقسيم عمليـة إعداد الخطة إلى مر احل مختلفـة تتضـمن كل مرحلـة خطوات و أنشطة مختلفة، والتي التي يمكن تنفيذ بعضها في نفس الوقت. (Unesco(B), 2010, 13-15) ومر احل إعداد الخطة الاستر اتيجية وخطو اتها هي كما يلي:

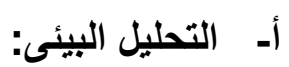

يمكن تطوير محتوى الخطـة الاستر اتيجية بعدة أسـاليب، ويعـد أسـلوب التحليل الرباعى (SWOT Analysis) أحد الأسـاليب الثـائعة الاستخدام في عمليـة التحليل البيئى لمؤسسات التعليم العالي بشقيه الداخلى و الخـارجي. وكلمـة SWOT تتكون مـن الحروف الأولى للكلمـات Strengths و و Oppoaknesses و و

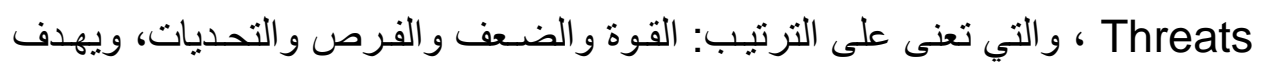
هذا الأسلوب إلى تحديد نقاط القوة والضعف في المؤسسة و والفرص و التحديات في البيئة الخارجيـة للمؤسســة. ويمكن لفريق وحدة التخطيط الاسـتر اتيجي اسـتخدام هذا التحليـل لتحديد العوامل وتطوير الاستر اتيجيات التي قد تبني على نقاط القوة، أو تقلل مـن نقاط

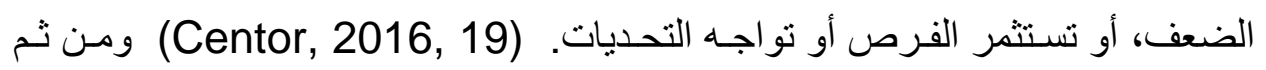
يتضمن التحليل البيئى ما يلي: • تحليل البيئة الداخلية: ينظر للبيئة الداخلية على أنها: مجموعة من العو امل التي يمكن للمؤسسـة التحكم

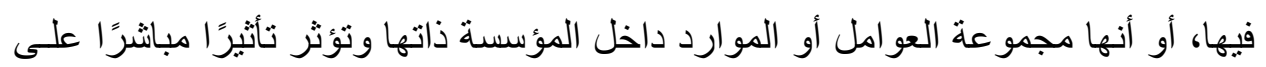
أدائها، ويمكن من خلال القرارات الإدارية تعديلها أو تغيير ها أو السيطرة عليها. وتتكون

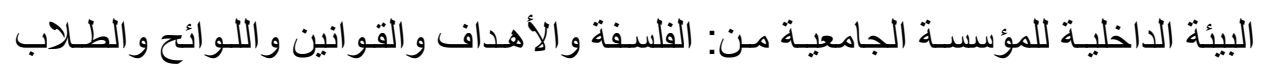




\section{د/ وفـاء عبد القتــاح محمـود}

وأعضـاء هيئسة التـدريس والجهـاز الإداري و المنــاهج وطـرق التـدريس ونظـم التقـويم والامتحانات و الموارد المالية و التسهيلات الماديـة الداعمـة وقو اعد البيانـات و المعلومـات

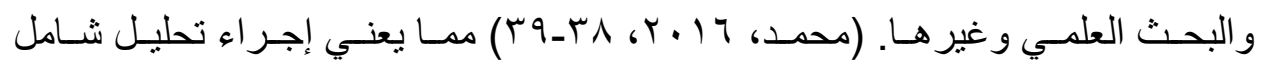
لعناصر ومـدخلات الوضـع الحـالي للمؤسسـة لتحديـ مسـتوي الأداء ونقـاط القوة ونقـاط الضعف.

\section{تحليل البيئة الخارجية:}

يستند التحليل الخارجي على فكرة أن هنالك عو امل في البيئة الخارجيـة لا يكون للمؤسسة أي سيطرة عليها، ويتم تصميم هـذا النـوع مـن التحليـل بطريقة تتيح للمؤسسـة تقييم هذه العوامل وأثرها عليها، ويغطي التحليل ست مجالات من التأثير، تشمل: المجـال الاجتمــاعي، المجــال الـديمغر افي، المجــال الاقتصــادي، المجــال السياسـي، المجــال

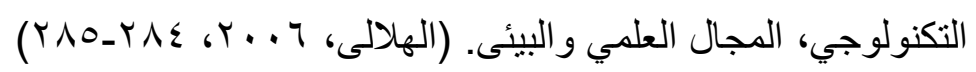
و عنــد إجـر اء التحليـل البيئـى الـداخلي والخـارجي يمكـن اسـتخدام الاسـتبانات و المقـابلات و العصـف الذهني و عقد ورش العمـل وغير هـا مسن أسـاليب الحصــول على المعلومات المطلوبـة، كمـا يمكن الاعتمـاد على نتـائج الدراسـات و البحـوث التشخيصـية و التقويمية و الاستطلاعية حول المؤسسة وبيئتها لتوفر موردًا متجددًا من المعلومـات أمسام فريق التخطيط الاستر اتيجي تتيح له إمكانية تقدير الموقف الاستر اتيجي للمؤسسـة في أي

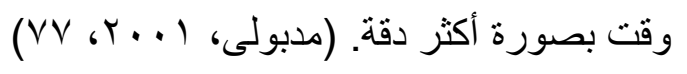

وبعد إتمام مرحلة التحليل البيئى يقوم فريق التخطيط الاسـتر اتيجي بإعداد قائمسة

تحوي نقاط القوة و الضعف في البيئة الداخلية و الفرص و التحديات في البيئة الخارجية. ب- تحديد رسالة وروئية المؤسسة: تعرف الرسالة بأنها: الإطار المميز للمؤسسة عن غير ها من المؤسسات الأخرى من حيث مجال نشاطها ومنتجاتها و عملائهـا وأسـو اقها، والتـي تعكس السبب الجـوهرى

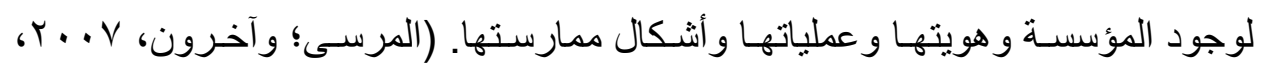

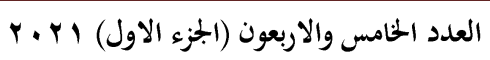

$$
\begin{aligned}
& \text { (207) } \\
& \text { مجلة كلية التربية- جامعة عين شمس }
\end{aligned}
$$




\section{استخدام أسلوب بيرت PERT في تخطيط برنامج لتدربب فرق التخطيط الاستراتيجي في الجامعات المصرية}

جام) وتهتم رسالة المؤسسة بالإجابة على الأسئلة التالية: لماذا وجدت المؤسسة؛؛ مـا هي طبيعة عملها؟، من هم عملاؤها؟، ما القيم التي تحكم عمل المؤسسة؟، ما الآلية التي تقدم

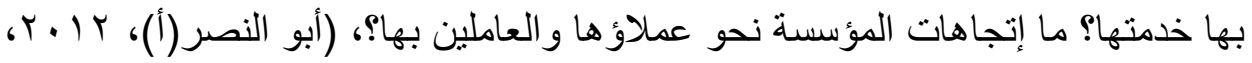

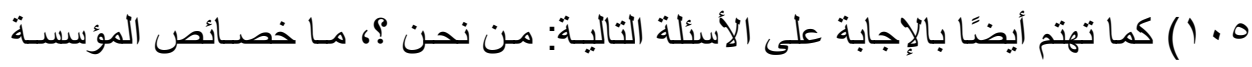

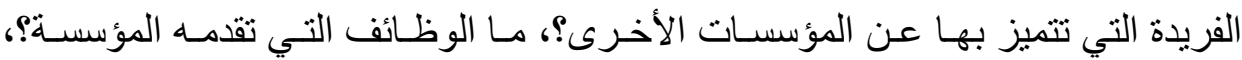

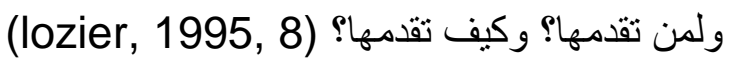
وتتسم رسالة المؤسسة بعدد من السمات الرئيسة مثل: الوضسوح و البسـاطة ودقة التعبيـر، القابليـة للتحـول إلىى سياسـات وخطط، الو اقعيـة و الموضـوعية، إنـارة وتعميق

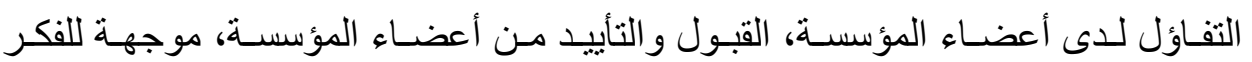
و الممارسات الإدارية لقيادات المؤسسة، تدل على غايـات المؤسسـة وأهدافها ومقومـات تحقيقها، توضح فلسفة المؤسسة ودستور ها في أداء أعمالها، تؤكد التر ابط بين إمكانيات

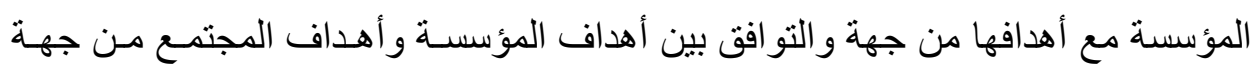
أخرى، تعزز آلية المشاركة في اتخاذ القرارات داخل المؤسسة، الارتباط بقيم ومعتقدات

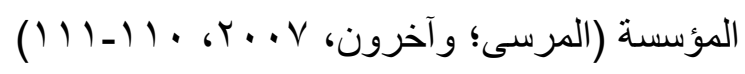

أمـا الرؤيسة الاسـتر اتيجية تعبـر عـن الصـورة المبتغــاة للمؤسســة في المسـتقبل. ورؤية المؤسسة الجامعية عبارة عن الطموحات والآمـال التـي تسـى إليهـا الجامعـة في

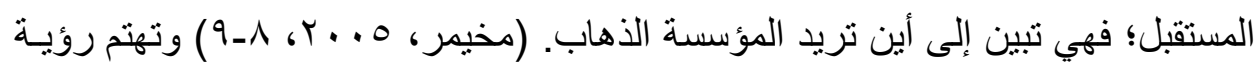

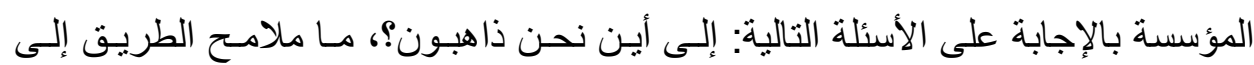

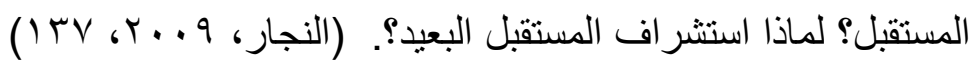
وتتسم رؤيـة المؤسسـة الجيدة بعدد مـن الســات مثنل: الواقعيـة ودقـة الصـياغة

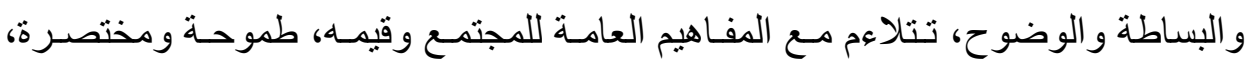
تستمد أصولها من ماضى المؤسسة وحاضر ها، دليل لتحقيق الرسالة. 


\section{د/ وفـاء عبد الفتــاح محمـود}

ويعـد المصـدر الأساسـي لبنـاء رسـالة المؤسسـة ورؤيتهـا القوانين و التشـريعات

و القرار ات و اللو ائح التففيذية التي تتظم عمل المؤسسة. وكذلك تشتق الرسالة من المجتمـع المحيط بالمؤسسة، وذلك بالتركيز على متطلبات المجتمع من المؤسسة ومجالات التعامـل معها. بما بعنى نأثر رسالة المؤسسة بالبيئة الداخلية و الخارجيـة. وكذلك يسـاعد في بنـاء رسالة المؤسسـة ورؤيتهـا الإطـلاع على عدد مـن بيانـات الرسـالة والرؤيـة للعديـد مـن المؤسسات للاسترشاد بهـا مـن حيـث الصـياغة والمحتوى و البنـاء و الطـول. كمـا تتدخل مهارة فريـق التخطيط الاسـتر اتيجي في الإبتكـار والإبـداع و التفكير التـأملي في تحديـد

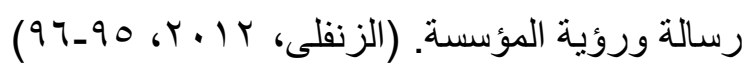

ويعتمد فريق التخطيط في بناء بيان رسالة جيدة ورؤية جيدة على مشـاركة أكبـر

عدد ممكن مـن أعضـاء المؤسسـة وعناصـر المجتمـع المـدني للوصـول لأفضـل صـورة ممكنة، ويـتم عقد الاجتماعـات لفريـق التخطيط الاسـتر اتيجي و الأطـر اف المعنيـة حيـث يطلب رئيس الفريـق مـن الأعضـاء أن يقدم كـلا مـنهم نموذجًا مقترحًا لرسـالة ورؤيـة المؤسسة، ثم يتم مناقثة ما توصل إليه الفريق في اجتماع عام للوصول إلى أول صسياغة لرسالة المؤسسة ورؤيتها كمسودة، ثم يقوم كل عضو في الفريق بإعداد مقترح بالرسـالة وبالرؤية الجديـدة بعـد إجـر اء تتقيح للمسـودة، ويقوم رئيس الفريـق بجمع تلك النمـاذج

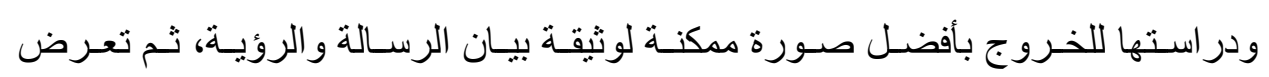
للمناقشة مرة أخرى حتى يتم التوصل إلى الصيغة النهائية .(عوض، ع . . ؟ ، ع ) ج- تحديا الغايات والأهداف الاستراتيجية: الغايات Goals هي أهداف تسعى المؤسسة إلى تحقيقها على المدى البعيد وهي تتسم بالعمومية و الثمول. أما الأهداف objective يقصد بهـا النتائج المطلـوب تحقيقها لترجمـة رسـالة المؤسسـة ورؤيتهـا إلىى واقع عملي وتتسـم الأهـداف بالتحديــ و إمكانيـة القياس و الميل إلى التقصيل، كما تتميز الأهداف بأنها: وضع مرغـوب فيـه، نتيجـة يمكن تحقيقها، إطار زمني يمكن من خلالـه تحقيتق الأهداف المستقبلية. (المرسـى؛ و آخـرون،

$$
\begin{aligned}
& \text { العدد الخامس والاربعون (الجزء الاول) ا ب. r } \\
& \text { (209) } \\
& \text { مجلة كلية التربية- جامعة عين شمس }
\end{aligned}
$$


استخلام أسلوب بيرت PERT في تخطيط برنامج لتدريب فرق التخطيط الاستراتيجي في الجامعات المصرية

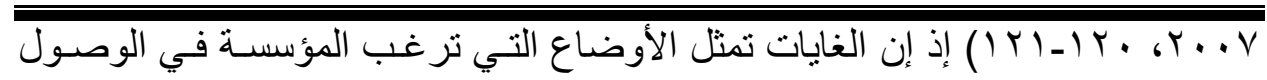

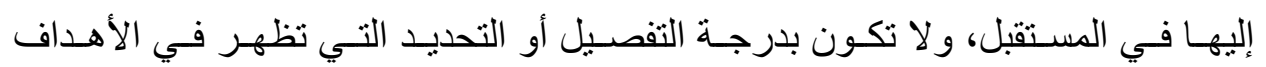

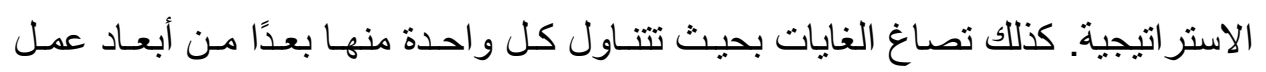

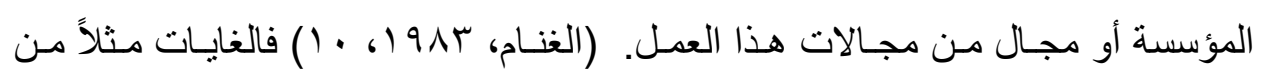

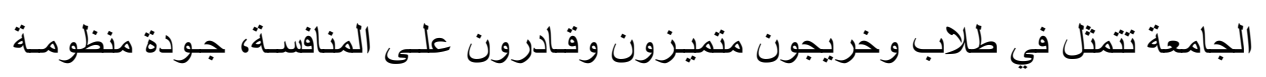

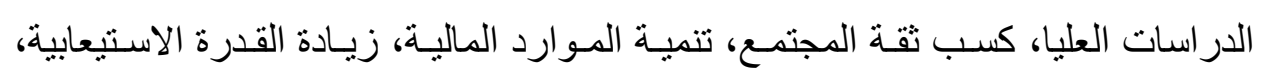
تعزيز المكانة الدولية و غير ها.

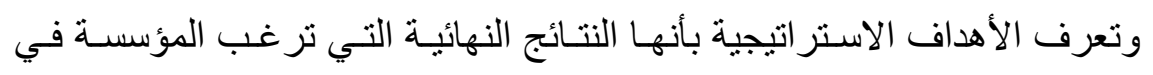

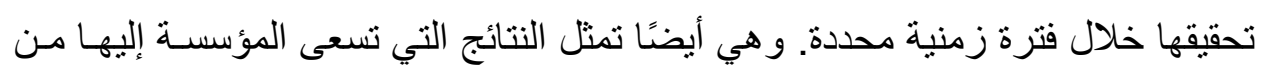

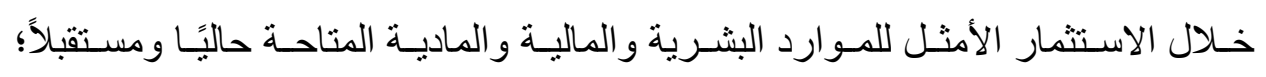

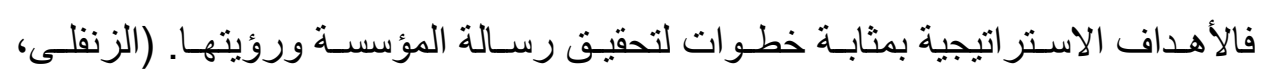
$(1 \cdot \varepsilon, r \cdot)^{\prime} r$ و الأهداف الاستر اتيجية تشتق من فلسفة المجتمع وقيمه وثقافته المبنية في ضـو

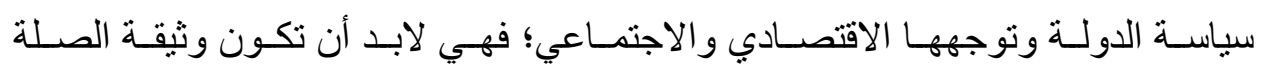

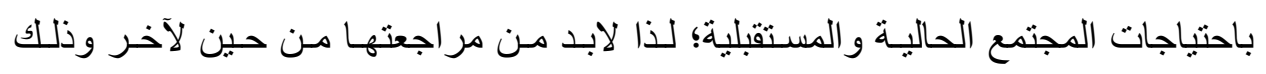

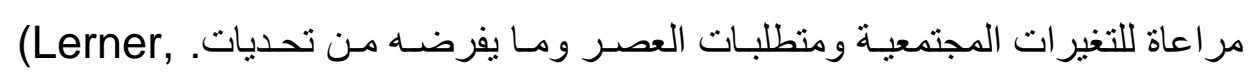

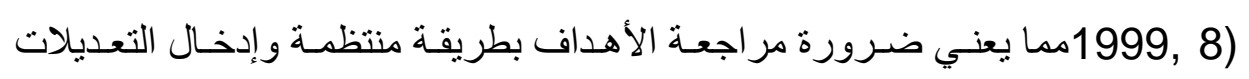
عليها في ضوء التحليل البيئى للمؤسسة. د- صياغة الخطة الاستراتيجية:

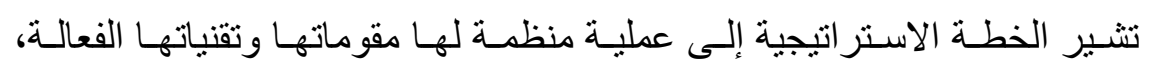
تسـتخدم المـنهج العلمـي لاستشـر اف المسـتقبل، وتحليـل بيئـة المؤسســة التعليميـة داخليًا

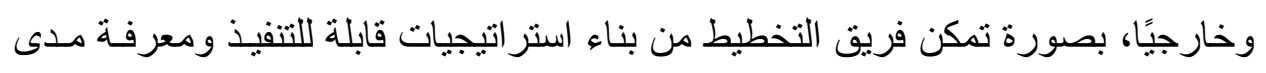

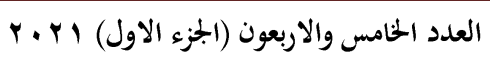

$$
\begin{aligned}
& \text { مجلة كلية التربية- جامعة عين شمس }
\end{aligned}
$$




\section{د/ وفـاء عبد القتــاح محمـود}

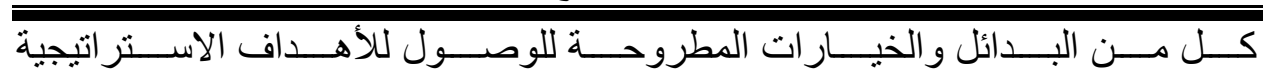

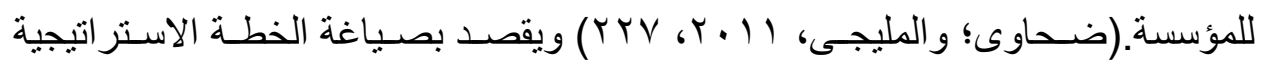
تحديد غايـات المؤسسـة وأهدافها الاسـتر اتيجية في ضـوء رسـالتها ورؤيتهـا، ثم تحديـد

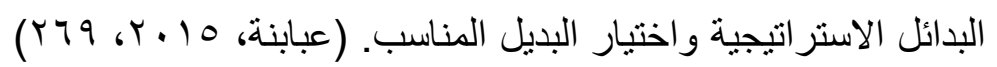
وبعد تحديد رسالة المؤسسة ورؤيتها وتشخيص الوضع الحالي، وتحديد الأهداف الاستر اتيجية المرغوبة، يقوم فريق التخطيط بتحليل الفجوة، وهـو إجراء مهم في سبيل الوصول إلى القضـايا أو المواقف الاستر اتيجية البديلـة، ويعني تقويم الفَرق بـين الوضـع الر اهن للمؤسسة والمستقبل المر غوب لها، ويساعد تحليل الفجوة على اختيار اسـتراتيجية معينة وتخصيص الموارد اللازمة لسد الفجوة. (عقلان، 9 . . Y، س I I) وتعد مرحلة تحليل الفجوة هي الوقت الملائم لاتخـاذ القرار ات التصـحيحية، و إذا مـا كانت الفجوة بين الوضع الحالي والوضع المر غوب فيه واسعة للغاية ويتعذر إغلاقهـا ينبغـي إعادة النظر في الأهداف المأمولة، أو اقتر اح حلول لإغلاق الفجوة، وبالنسبة لكل فجوة مـن الفجوات التي لا يمكن إغلاقها باسـتر اتيجية واضـحة، ينبغـي أن يرجـع فريـق التخطيط إلى المر احل الأولى في عملية التخطيط ومحاولة إدخـال بعض التعديلات على رؤيسة المؤسسـة

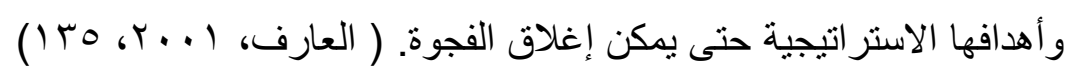
وبشكل عام هنالك أربع منهجيـات أساسية لســ الفجوات بين الحالـة التي عليهـا المؤسسة في الوقت الراهن والحالة التي تر غب في الوصـول إليهـا، وهـي: زيـادة المـدة الزمنية المحددة لإنجاز الهدف، تقليـل نطـاق الهدف بحيـث يكون قابـل للتحقيق بصـورة أفضل، إعادة توزيـع المـوارد المالبـة و الماديـة والبشـرية، الحصـول على مـوارد جديـدة

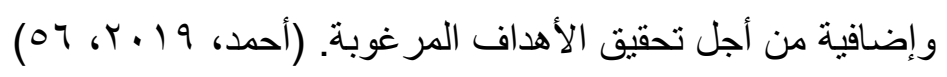

وبعد إنتهاء فريـق التخطيط الاسـتر اتيجي مـن تحديــ رسـالة المؤسسـة ورؤيتهـا وأهدافها، وتحليل كل مـن البيئـة الخارجيـة للمؤسسـة والأداء الـداخلى لهـا، يقوم الفريـق بتجميع ما سبق في مجموعـة مـن التوجهات الاسـتر اتيجية الأوليـة للمؤسسـة، أي تحديــ 
استخدام أسلوب بيرت PERT في تخطيط برنامج لتدريب فرق التخطيط الاستراتيجي في الجامعات المصرية فيطاية

الموقف الاستر اتيجي البديل للتوصل إلى ملامح استر اتيجية المؤسسة. (العسارف، ا ...ب،

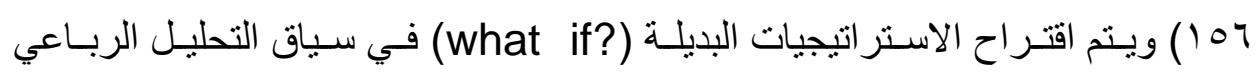
. ويوضح الجدول التالي مصفوفة التحليل الرباعي: (SWOT Analysis) جدول (1)

\section{(SWOT) مصفوفة}

\begin{tabular}{|c|c|c|}
\hline نقاط الضعف (W) & نقاط القوة (S) & \\
\hline موقف (الضعف/ الفرص) & موقف (القوة/ الفرص) & الفرص (0) \\
\hline موقف( الضعف/التحديات) & موقف( القوة/ التحديات) & التحديات (T) \\
\hline
\end{tabular}

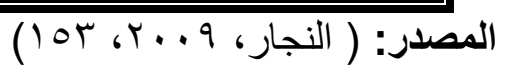

يتضح من الجدول ( ( ) أن هناك أربع مواقف استر اتيجية محتملـة للجامعـة في

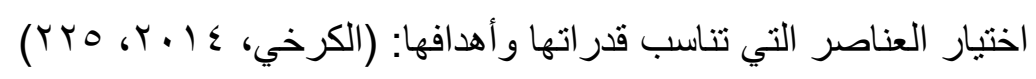

استر اتيجيات القوة/ الفرص (S-O): تهنم بمواصلة توظيف الفرص التي تنتلاءم مـع عناصر القوة لدى الجامعة.

اسـتر اتيجيات الضـعف/ الفـرص(W-O): تهـتم بيـل الجهود للتغلب على مـواطن

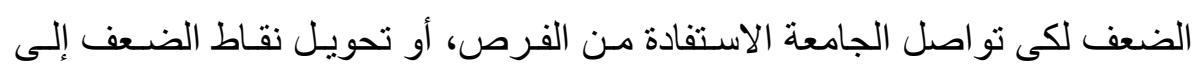
نقاط قوة.

استر اتيجيات القوة/ التحديات (T-S): تحدد الطرق التي يمكن للجامعة استخدام نقاط القوة لتقليل تعرضها للمخاطر الخارجية. استر اتيجيات الضعف/ التحديات (W-T): بتأسيس خطة لحمايـة نقاط الضـعف لدى الجامعة من سر عة تأثير ها بالتحديات الخارجية. 


\section{دارفــاء عبد القتــاح محمـود}

ويقوم مدير فريق التخطيط الاستر اتيجي بعقد اجتماعـات نقاشـية للفريق لتحديد

أنسب البدائل الاستر اتيجية المتاحة والأكثر قدرة على تحقيق رسـالة المؤسسـة ورؤيتهـا و أهدافها الاستراتيجية، ومن معايير المفاضلة بين البدائل الاستراتيجية: المـوارد الماليـة و التسهيلات الماديـة، التوقيت الملائم للاسـتر اتيجية، التكامـل المؤسسـي مـع المؤسســات

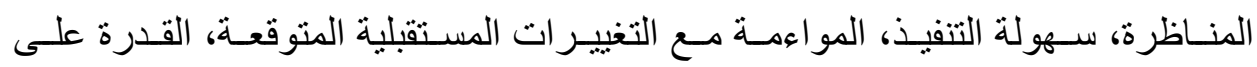
التحديث التقني و المعلوماتي في المؤسسـة، التركيز على التنميـة البشـرية، بـديل يترتب

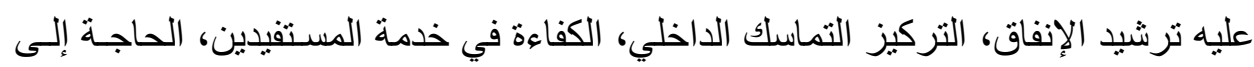

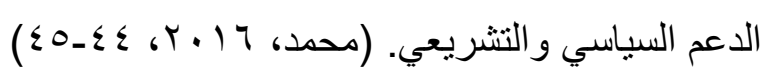

بعد تحديد الاسـتر اتيجية الأكثر مناسبة للجامعـة يتم وضـع خطـة لتحقيق هذه

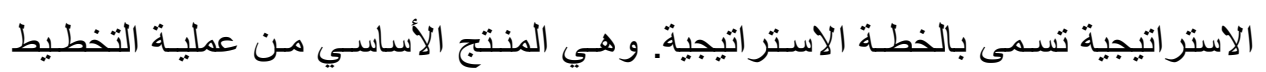

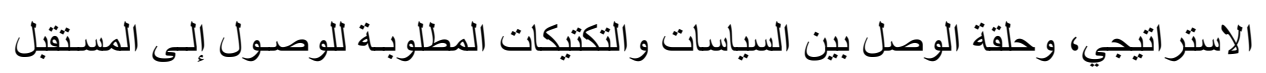

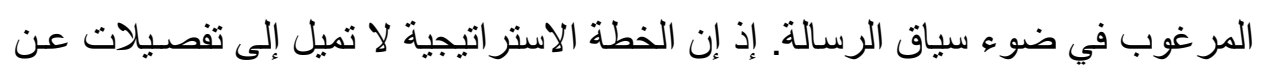

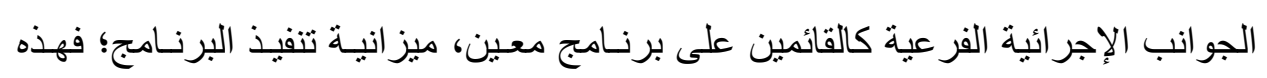

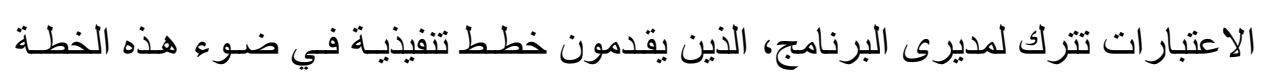

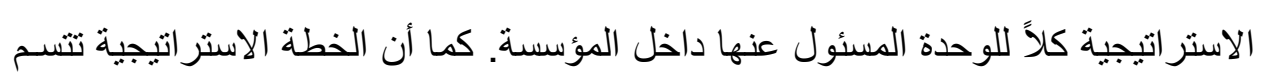

بأنها: بالمرونة والديناميكية والقابلية للتعديل. (El- Hout, 1994, 59-60)

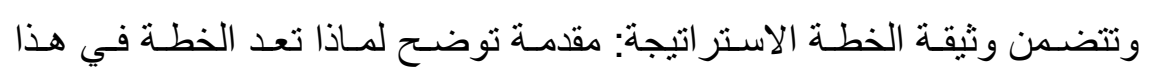

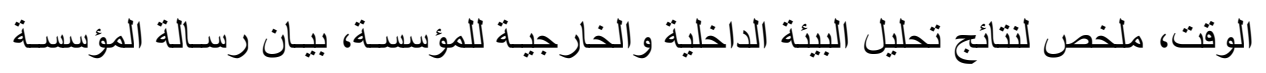
ورؤيتهـا، مجموعـة الغايـات و الأهـداف الاسـتر اتيجية، ملخـص للاسـتر اتيجيات البديلــة ومقارنة بينها، تحديد البديل المختار، ملخص لتحليل الفجوة، وصف البديل الاستر اتيجي المختار ومحاوره بتفصيل كاف، ترنيـات ومتطلبـات تنفيذ الخطـة و الرقابـة و المر اجعـة.

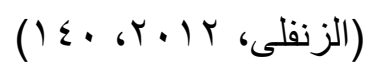

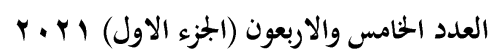

(213)
مجلة كلية التربية- جامعة عين شمس 


\section{استخدام أسلوب بيرت PERT في تخطيط برنامج لتدربب فرق التخطيط الاستراتيجي في الجامعات المصرية فيطاية}

ويقوم فريق التخطيط الاستر اتيجي بإعداد المسودة الأولى للخطـة الاستراتيجية،

وبعد ذلك يتم در استها بمعرفة صناع القرار ومجلس إدارة التخطبط الاستر اتيجي و عدد

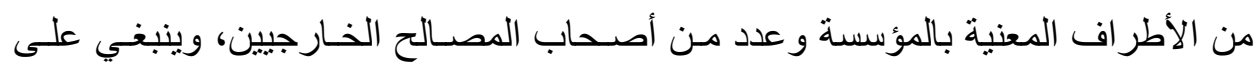
فريق التخطيط الاستراتيجي قبول التعديلات في حالة إنها تؤدي إلى تحسين الخطة، وبعد

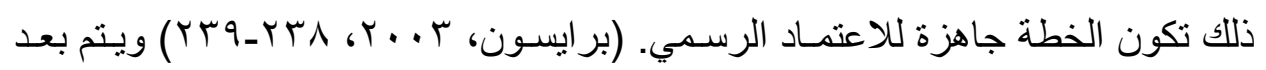
ذلك ترجمتها إلى الخطط التنفيذية متضمنة بر امج ومشرو عات وأنشطة ومؤشر ات الأداء ومسئولية التنفيذ وتخصيص الموارد المالية الحكومية والذاتية. وبعد اعتماد وثيقة الخطة يجب إيصالها إلى كل أعضــاء المؤسسـة حتى ينسـى لهم معرفة الغايات و الأهداف الاستر اتيجية المأمولة، ويتم إيصال الخطة إليهحم مـن خـلال

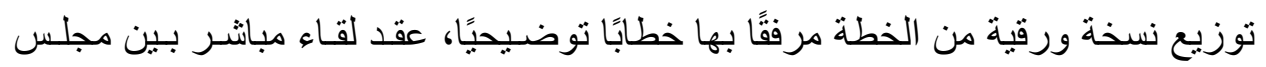
إدارة المؤسسة ومديرين الأجهزة الإدارية وفريق التخطيط لتعريف الخطـة وتوضيحها، إصدار نشر ات بها موضو عات التخطيط وتوزيعها في الأماكن الملائمـة، و إرسـالها على

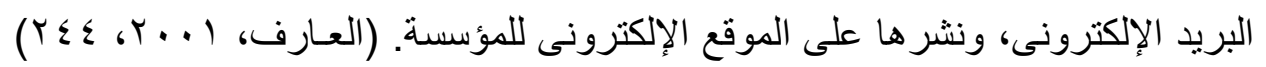
وكذلك يتم إيصالها لفئات خارج المؤسسة مثل المستفيدين من خدمات المؤسسة، الثـركاء

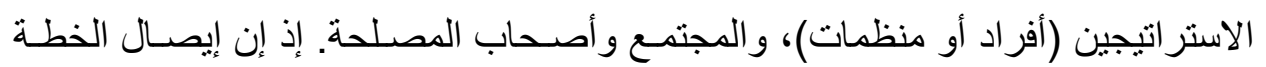
إليهم يسـهم في تحسـين العلاقـات مـع المستقفيدين مـن خـلال التركيز على احتياجـاتهم

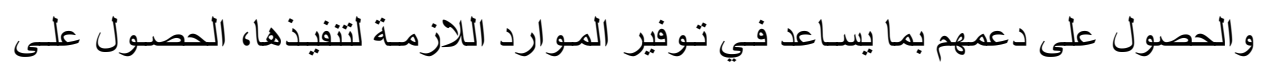
مو افقة الثركاء ومشتاركتهم. ويتم ذلك من خلال الاجتماعات المستمرة مـع هذه الفئات، وتوفير هـا فـي المـؤتمرات و النـدوات و الاجتماعـات الدوريــة التـي تجمـع المسـتفيدين الخارجيين، و إرسـال الخطـة باليد أو بالبريد الإلكترونسى إلى المستفيدين. (بـن حمدان؛

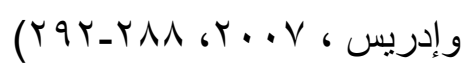

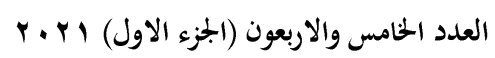

مجلة كلية التربية- جامعة عين شمس 


\section{د/ وفــاء عبد القتــاح محمـود}

ه- تحديد بدائل وقرارات في حالة الطوارئ:

تعـد المخـاطر الطارئسة تحـديًا كبيـرًا لعمليـة التخطيط الاسـتر اتيجي في التعليم

الجامعي، والفثل في إدارة المخاطر بشكل استر اتيجي بضع المؤسسـات في حالـة ماليـة حرجة. وتتطوي إدارة المخـاطر على اتخـاذ القرار الذي يأخذ في الاعتبـار إجـراءات

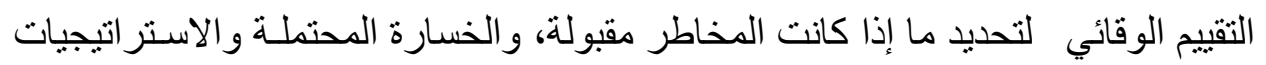

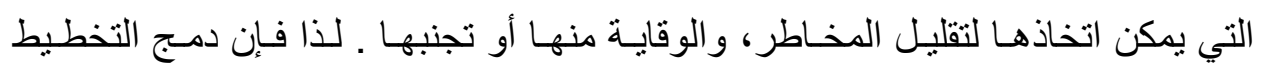
الاستر اتيجي و إدارة المخـاطر والأزمـات في عمليـة منسقة واحدة يـوفر إطـارًا منطقيًا ومر غوبًا للخطـة الاستر اتيجية لتعظيم إمكانـات تحقيت الرؤيسة والأهداف الاسـتر اتيجية

وتعظيم القوة المالية للمؤسسة. (Boston, 2016, 21)

فقد تتعـرض كـل مؤسسـة إلى إحـاث طارئسة أو أزمـات يجب التخطبط لهـا،

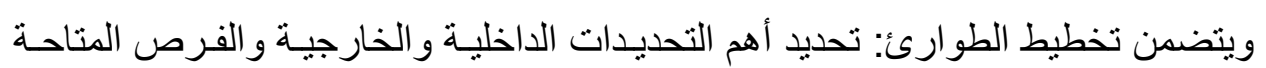

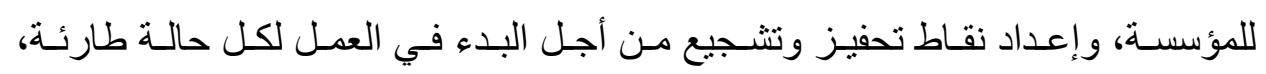
و الإتفاق على خطوات العمل التي سيتم اتخاذها لكل نقطـة مـن نقاط التحفيز و التشــيع.

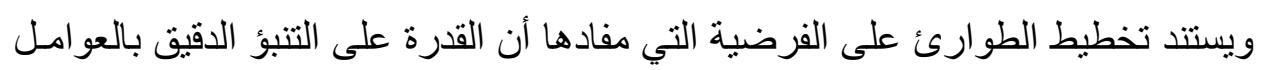

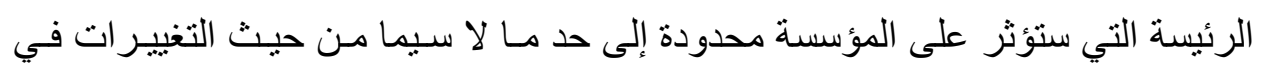
تللك العو امل، ومع ذلك يجب أن يكون فريق التخطيط قادرًا على إعداد خططُ بديلـة بنـاءً

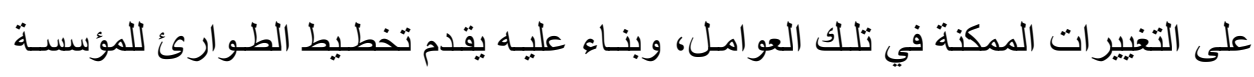
تشـكلية عريضــة مـن اسـتر اتيجيات العمـل التـي يمكن اسـتخدامها مـع عـد كبيـر مـن

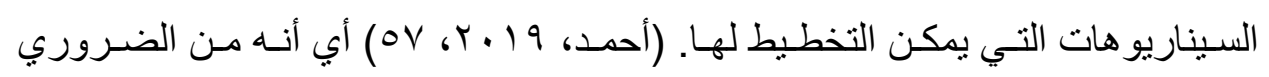
وضع خطة للطوارئ للتعامل مع المخاطر أو الأزمـات التـي تعوق الخطـة الاستر اتيجة

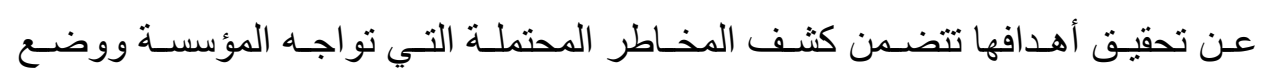
السيناريو هات البديلة المناسبة لمو اجهنها.

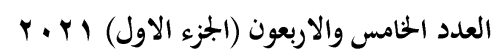

(215)
مجلة كلية التربية- جامعة عين شمس 
استخدام أسلوب بيرت PERT في تخطيط برنامج لتدريب فرق التخطيط الاستراتيجي في الجامعات المصرية

و- ترجمة الخطة الاستراتيجية إلى الخطط التنفيذية:

بمجرد اختيار الاستر اتيجيات طويلة المدى، سـتكون الخطوة التاليـة هي وضـع الته

أهداف قصيرة المدى و استر اتيجيات قصيرة المدى لتحقيق أهداف و استر اتيجيات طويلـة المدى. (Kriemadis, 1997, 243) ويتولى فريق التخطيط الاستر اتيجي مـع

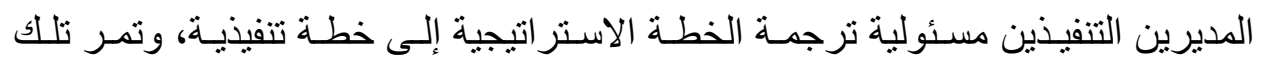
العملية بخطوتين رئيسيتين و هما: الأولى، تحديد الأهداف ومؤشر ات الأداء و التي يمكن من خلالها تحقيق الاستر اتيجية. الثانية، وهي تحديد مساهمة كل وحدة تنظيمية في تحقيق

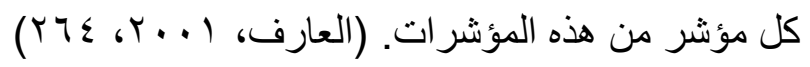

ومؤشر ات الأداء تعني طريقة لقياس مدى تحقق وتنفيذ الأهداف، ويمـر إعداد

مؤشرات الأداء بخطوات تبدأ منطقيًا بتحديد الأهداف، ثم تحديد المؤشـرات التي تغطى

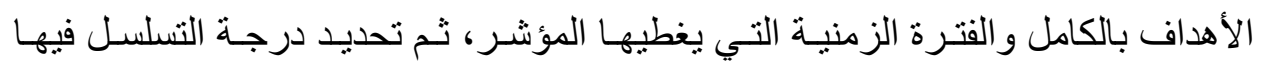

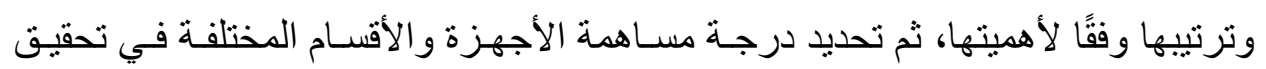

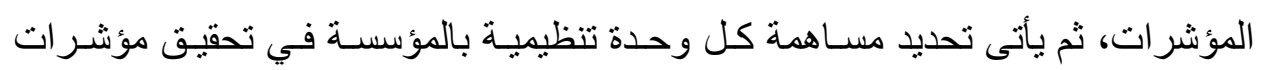
الأداء. (ماهر، 9. 9. T)،

وبذلك فإن الخطة التنفيذية تكون أكثر تفصيلاً وأكثر تحديدًا؛ وتثـمل هذه الخطـة

على تحديد: الغايات و الأهداف الاستر اتيجية المرجو تحقيقها، الأنشطة المطلوبـة لتجـاوز

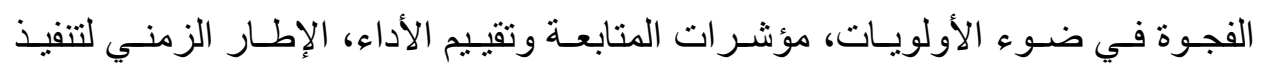
الأنشطة، المسئول عن تنفيذ الأنشطة التي تتضمنها الخطة، التمويل المطلوب لتحقيق كل هدف من الأهداف الاستر اتيجية، بـدائل وقرارات تتعلق بـإدارة المخـاطر أو الأزمـات.

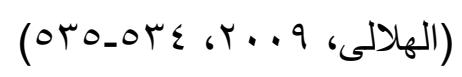

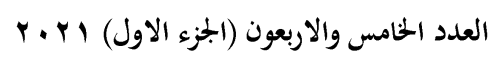

(216)

مجلة كلية التربية- جامعة عين شمس 
أن مسئولية تنفيذ الخطة تقع على عـاتق الأجهزة التنفيذيـة، ومتابعـة تنفيذها تقع

على عاتق فريق منابعة الخطة الاستر اتيجية، ولما كان من المهم أن تكون عمليـة متابعـة

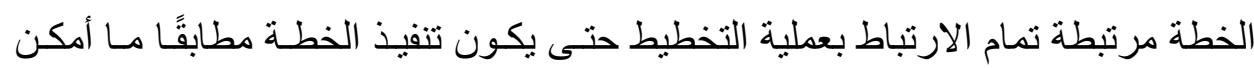

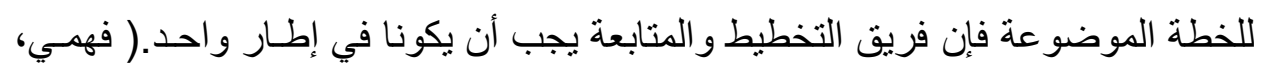

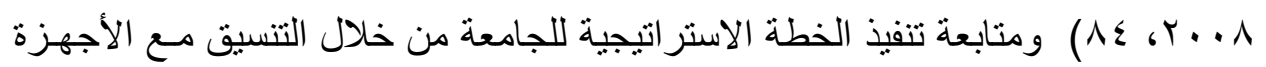

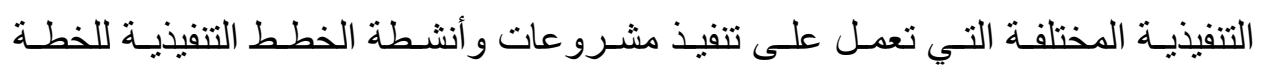

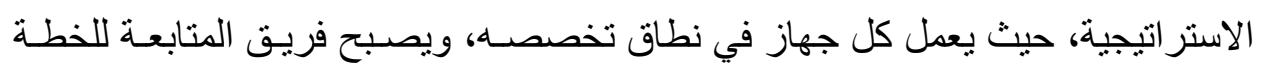

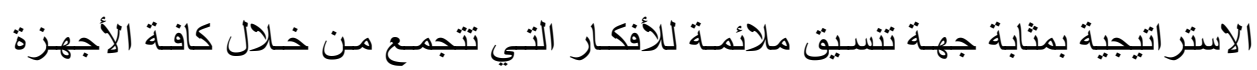
التتفيذية، بحيث يكون لاى وحدة التخطيط الاستر اتيجي الصسورة الإجماليـة التي تسطيع

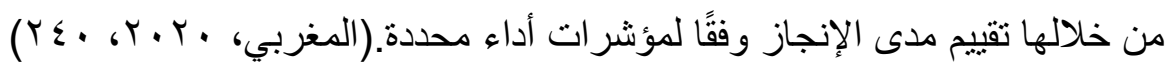

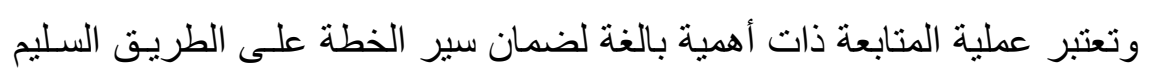

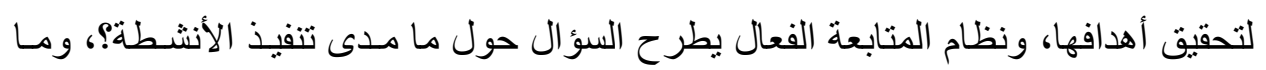

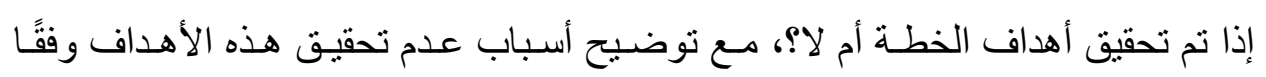

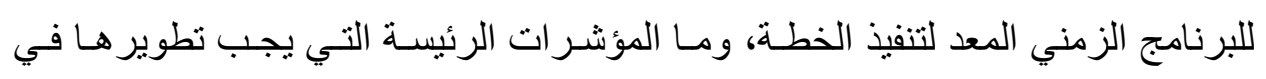

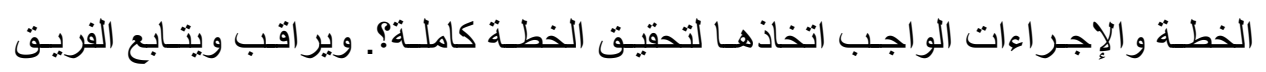
المسئول عن المتابعة تغطية جميع الأنشطة من خلال جمع البيانات وتحليلها في صـورة تقارير للمتابعة. وتتنمل أهم عناصر المتابعة ما يلي: (Unesco, 2015,26)

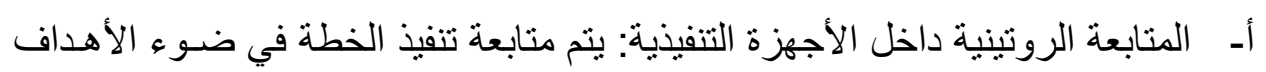
والأنشطة والمؤشرات الواردة في الخطط التنفيذية المنبثقة عن الخطـة الاستر اتيجية

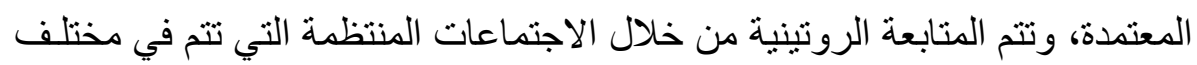

الأجهزة.

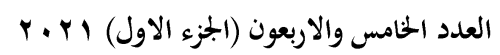

(217)
مجلة كلية التربية- جامعة عين شمس 


\section{استخدام أسلوب بيرت PERT في تخطيط برنامج لتدربب فرق التخطيط الاستراتيجي في الجامعات المصرية فيطانية}

بـ المتابعة الدورية من قبل فريق المتابعة: ينبغي أن يقوم فريـق المتابعـة بإعداد تقريـر

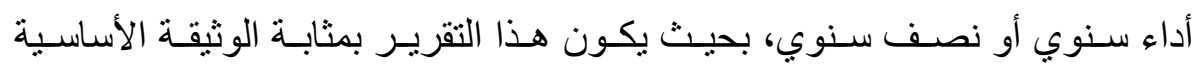

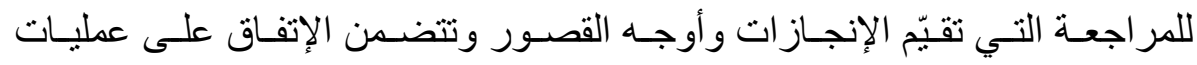
التحسين. وينبخي أن تكون كل مر اجعة بمثنابة مـدخلات لخطـة العمل السنوية للسـنة

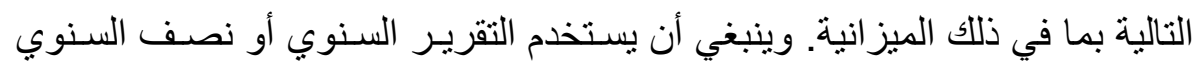
نفس النمط المستخدم في خطة العمل السنوية وأن يتضمن معلومات التكلفة الإجماليـة لكل نشاط ومعلومات عن التقدم المحرز في تحقيق الغايـات و الأهداف المحددة في الخطة.

ج- التقارير حول الخطط و الميزانيـات السـنوية: التقـارير هي للتحقق مـن أن عمليـات التنفيذ تتماشى مع توقعات الخطة، ينبغي إعداد تقارير الأداء الموجزة الموحدة بشكل منتظم في ضوء الخطوط العريضة و الأدوات المعدة من قبل فريق التخطبط وفريق المتابعة. ويتم تقديم التقارير إلى لجنة المر اجعـة داخل وحدة التخطبط الاسـتر اتيجي لتحديد الإنجـاز ات ومناقتــة المعوقـات وتقديم التوصيات، كذلك يتم تقديم التقـارير المنتظمة من الأجهزة الإدارية. r- تقويم الخطة الاستراتيجية والإعداد للخطة الجديدة: عملية التقويم تتم في ضوء الغايات و الأهداف التفصيلية للخطة وعـادةً تكون في منتصـف المـدة وفي نهايـة فتـرة الخطــة لتجنـب أي تضــارب في المصــالح ولضـــان الموضو عية ولزيـادة المصداقية. ويعتبر تقييم منتصف المدة تقيجم تكويني يدعم تتفيذ البرنامج بهدف تحسين الأداء. وقد تؤدي نتائج تقييم منتصف المدة إلى إعـادة النظر في أولويات الخطة أو تعديل أهدافها الاستر اتيجية، ويعد التقييم النهائي ختامي، حيث تهدف المر اجعة النهائية إلى تقييم النتائج وأهمية الخطة وفعاليتها، بالإضافة إلى تحليل الأسباب

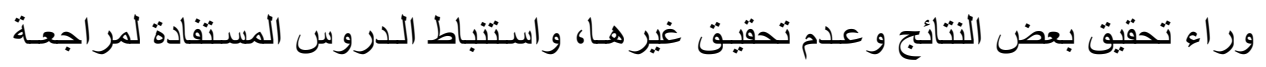

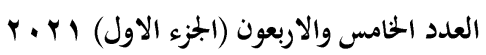

$$
\begin{aligned}
& \text { مجلة كلية التربية- جامعة عين شمس }
\end{aligned}
$$




\section{د/ وفـاء عبد الفتــاح محمـود}

السياسـات و لإعداد الخطة المتوسطة الأجـل المقبلـة أو التاليـة في ضـوء غايـات و أهداف جديدة تكون أكثر واقعية وأكثر قابلية للتنفيذ و أكثر قدرة على تحقيق احتياجات المؤسسـة.

(Unesco, 2015,26-27 )

يعـد نظـام مؤشـرات الأداء في المتابعـة والتقويم أداة رئيسـة للحكم على كفـاءة تحقيق أهداف الخطة، ويتم في ضـوئها رصـد الأداء في جميع خطـوات التنفيذ، وقيـاس الإنجاز ات المحقةة بالنسبة للأهداف الموضـو عة، للوصـول إلى حكم نهـائي حـول مـدى نجاح الخطة، وكذلك تحديد التعديلات التي يجب مر اعاتها عند الثـروع في وضـع خطـة

\section{جديدة.}

ثالثًا: مقومات نجاح فرق التخطيط الاستراتيجي بالجامعات: يتطلب تطبيق عملية التخطيط الاستر اتيجي الناجحـة في الجامعـة وكلياتهـا تـوفر مجمو عة من المقومات تساعد على زيادة كفاعة وفعالية الفريق، و التي من أهمها: أـ ـ دعم القيادات العليا: ضرورة دعم الإدارة العليا لعمل الفريـق وتقديم كل مـا يحتاجـه أثناء عمله. بـ اختيار أعضـاء الفريق بدقـة: مر اعـاة الطـرق العلميـة في عمليـة اختيـار الفريـق مـع مر اعـاة القـدر ات و الخبـر ات والمهــار ات و الخصــائص الثخصـية، مر اعـاة العـدد المناسب من الأفر اد للعمل كفريق وضرورة مر اعاة التجانس بين الأفراد. ج- وضوح الأدوار المنوطة لأعضاء الفريق: ضرورة وجود توصيف وظيفي لكل لجنـة ولكل دور في الفريق؛ فأحيانًا كثيرة لا بستطيع الفرد تحديد ما هـو متوقع منـه القيـام به، أو يو اجه أعباء وظيفية أكبر من طاقته وقد يترتب عليه ظهور معوقات تعرقل عمل الفريق. د- تطوير فريق التخطيط: إن تشكيل القريق وتحديد قو اعد العمل واعتمـاد أسـس بنـاءه، وتوزيع العمل بين أعضاءه يتطلب ضرورة العمل المستمر على تطوير هذا الفريـق حتى يستطيع أداء مهامه، وحتى يتم ذلك لابد من وضع آليـات عمـل داخليـة لضـمان 


\section{استخدام أسلوب بيرت PERT في تخطيط برنامج لتدربب فزق التخطيط الاستراتيجي في الجامعات المصرية فيطانية}

بيئة عمل متحركـة ومتفاعلـة، لـللك بحتـاج الفريق بصـورة دوريـة مر اجعـة أدواره الوظيفيـة وكل منطلباتـه التنظيميـة مـن اتخـاذ قر ارات و اتصـال و علاقـات، و أيضًا ضـرورة تفحص طرق أدائسه وتحديد المشكلات و العمل على إيجـاد الحلـول لهـا. (0) (0)

ه- تو افر نظم المعلومات الاستر اتيجية: فالمعلومات لها دور أساسـي في كافـة خطوات عملية التخطيط الاستر اتيجي، ولتحقيق الاستفادة المثلى من تلك المعلومـات لابــ أن يتسم نظام المعلومات الاستر اتيجي بدقة المعلومات وشـوليتها وتو افرهـا في الوقت المناسب للإسهام في اتخاذ القرارات. و هذا يتطلب الاعتماد على الحاسب الآلي في تخزين أكبر كم من البيانات وتحليلها للاستفادة منها في أي وقت. و - توافر نظام الحوافز: لابد من استخدام الحوافز المادية و المعنويـة و المكافـآت لتشـجيع أعضاء الفريق على بذل الجهد لأداء الأعمال المطلوبة بكفاءة. و لابد أن بـرتبط نظسام الحو افز بصورة مناسبة وفعالة مـع اسـتر اتيجية المؤسسـة على المستويات الإداريـة

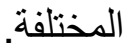
ز- تو افر نظام مالى: يجب أن يكون لدى المؤسسـة نظـام جيد لـلإدارة الماليـة يتم مـن خلاله نوفير الموارد المالية اللازمة لعملية التخطيط، وتعمل على توجيـة حصـة مـن

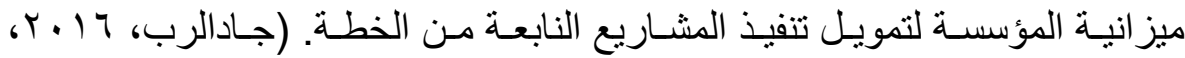

$$
(1 \cdot r-) \cdot r
$$

رابعًا: دواعى الحاجة إلى تدريب فرق التخطيط الاستراتيجي في الجامعات المصرية: هناك مجموعة من الدواعي و المبررات التي تستدعى ضـرورة تطوير الكفايـات التخطيطية لفريق التخطيط الاستر اتيجي من خلال التدريب، ومن أهمها: 


\section{د/ وفـاء عبد الفتــاح محمـود}

\section{1- حاجة الجامعة إلى التخطيط الاستراتيجي لتحقيق الميزة التنافسية:}

يعد الهدف الأساسي للتخطيط الاستر اتيجي الانتقال بالجامعـة مـن وضعها الحسالي

إلى وضع أفضل حيـث إنـه ينشسئ إطـارًا تتخذه الجامعـة لتحقيق النجـاح المنشـود، ويـوفر فرصة لمشـاركة جميع مكونات الجامعـة، يهدف إلى مواءمـة الجامعـة مـع بيئتهـا المحليـة و الوطنية و العالمية، وتسهيل تحديد الأولويات، وتبسيط عمليات التقيبم وتخطبط الميز انيـة. يعزز قدرة الجامعة على التفكير و العمل و التعلم بشكل استر اتيجي. عند حدوث ذلك، نتـهـ

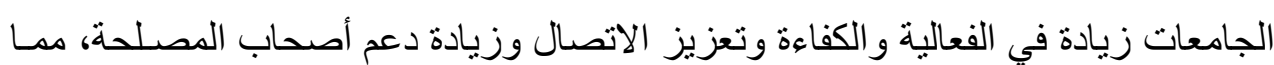

يعزز ذلك تحقيق ميزة تنافسية للجامعات. (Carpenter, 2019, 29) " فالتنافسية في التعليم الجـامعي تعني قدرة الجامعـة على تقديم خدمـة تعليميـة

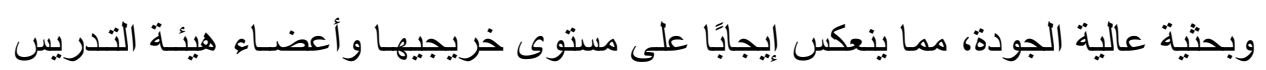

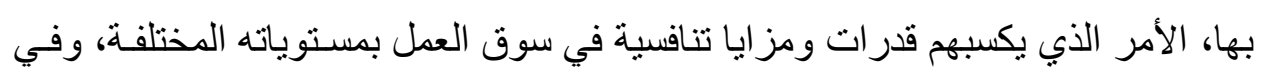

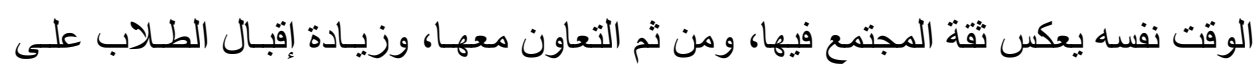

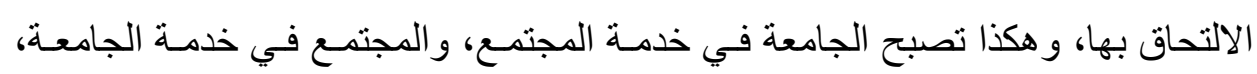

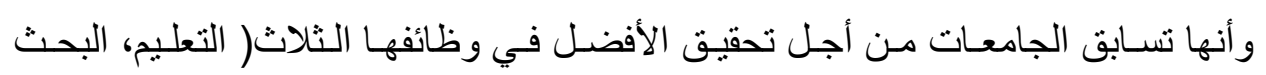

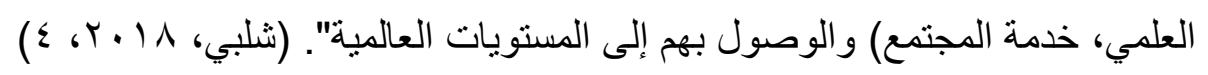

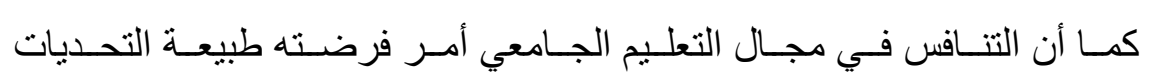

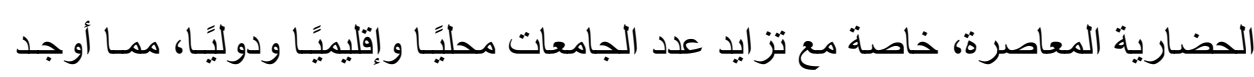
منافسة قوية بين هذه المؤسسات التعليمية، وأصبحت الحقيقة التي لامفر منها أن الجامعـة التي لن تسعى للوصول إلى ميزة تنافسية فسوف تفقد المكـان و المكانـة. (عبد الوهـاب،

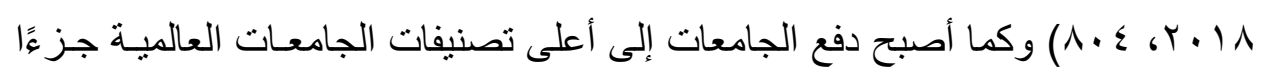

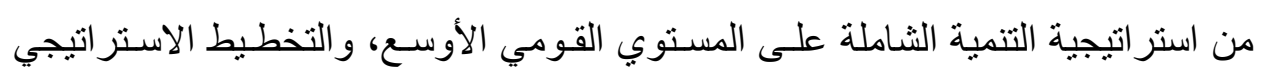

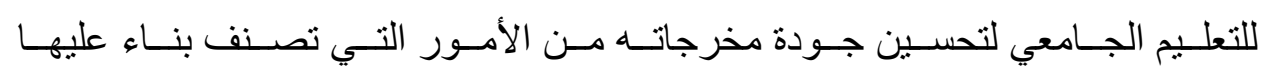
الجامعات. (University of Oxford, 2016, 20)

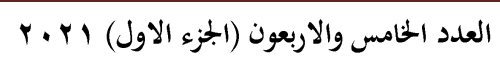

(221)
مجلة كلية التربية- جامعة عين شمس 


\section{استخدام أسلوب بيرت PERT في تخطيط برنامج لتدريب فرق التخطيط الاستراتيجي في الجامعات المصرية فيطاية}

وتوضح تقارير تصنيف الجامعات على مستوى العـالم تو اضـع مكانـة الجامعـات

المصرية. ويعتبر تمثيل الجامعات المصرية ضعيفًا جدًا في تقارير ترتيب الجامعـات بين أفضل . .0 جامعة في العـالم في تصنيف شـنغهاي للجامعـات العالميـة حيث إن مصـر

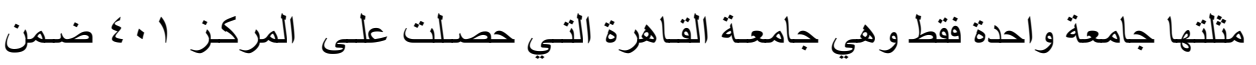

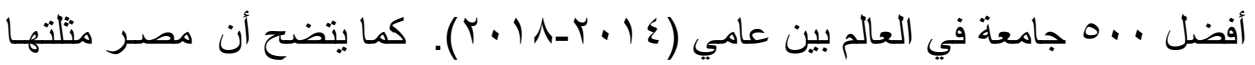
جامعة واحدة فقط في تصنيف كيو اس (QS) البريطـاني و هـي أيضًا جامعـة القـاهرة وكانت في هذا التصـنيف خـارج أفضـل . .0 جامعـة على مسـتول العـالم بين عـامي

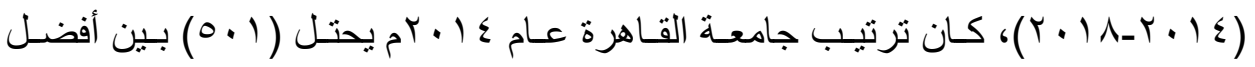

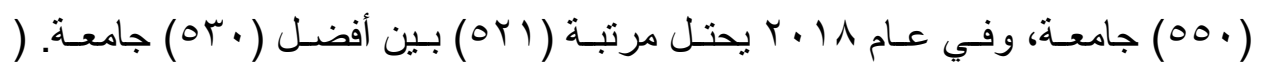

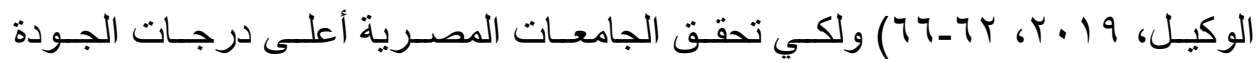
و الحصول على الإعنماد الأكاديمى و التنافسية، فإن سبيلها الأول في ذلك هو التخطيط الاستر اتيجي، و عمل خطة استر اتيجية جيدة للنهوض بجميع أبعاد الجامعـة. (عزازى، $(r, r \cdot 10$

بذلك تحتاج الجامعات المصرية إلى التخطيط الاستر اتيجي لتحقق مكانـة تنافسية متقدمة، يتناول هذا التخطيط الجامعـة مـن مختلف الأبعـاد داخليَّا وخارجيًا. وذلك عن طريق تحليل نقاط القوة والضعف في بيئتها الداخلية، والوقوف على قدر ات المنافسين، وتحليل الفرص والتحديات المحيطـة، ووضـع الأهداف المستقبلية، والوسـائل المناسبة لتحقيق هذه الأهداف. ويمكن الحكم بـأن التخطيط الاستر اتيجي هو المنهجيـة الثــاملة

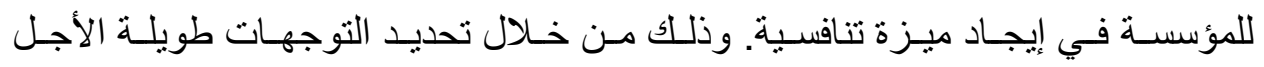
للمؤسسـة، وتحديـد مجـال نشـاطها، وحصـر المـوارد، و الإمكانيـات المتاحـة و الممكنـة،

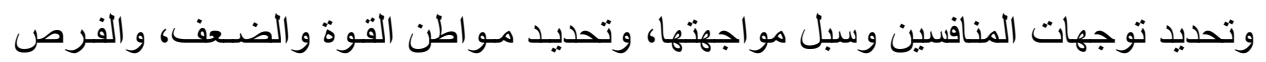

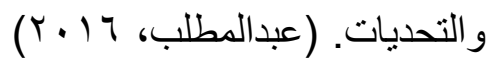

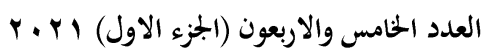

(222)
مجلة كلية التربية- جامعة عين شمس 


\section{داء وفـاء عبد القتــاح محمـود}

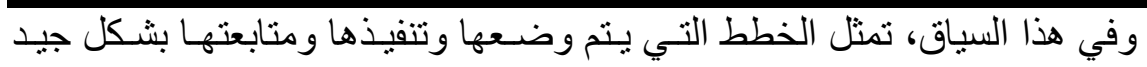

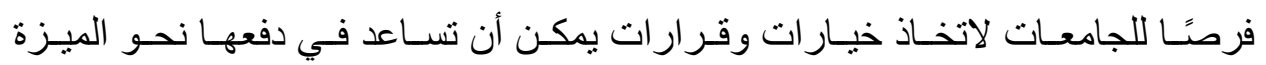
التنافسية. الأمر الذي يتطلب وجود فريق التخطبط الاستر اتيجي المتميز في وضـع خطـة استر اتيجية سليمة وجيدة تحقق الإنسجام بين رسالة الجامعة ورؤيتها، و غاياتها و أهدافها، وبين الرسالة والبيئة المحيطة بالجامعة. لذا يعتبر تدريب هذا الفريق على تطبيق منهجيـة

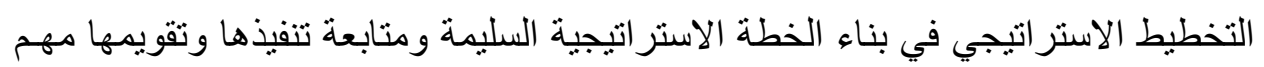
جدًا من الناحية العملية؛ فالتدريب يساعد على رفع كفاءة الفريق من خلال زيادة وتطوير معلوماتهم ومهار اتهم وتحسين قدر اتهم على أداء المهام الموكلة إليهح. r- ضعف عمليات التخطيط الاستراتيجي في الجامعات:

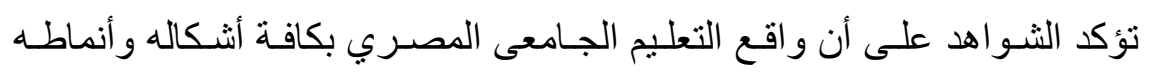

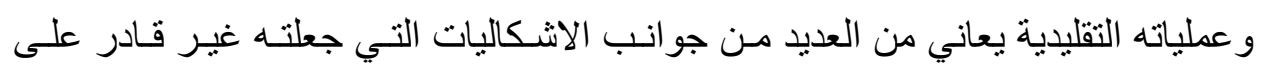

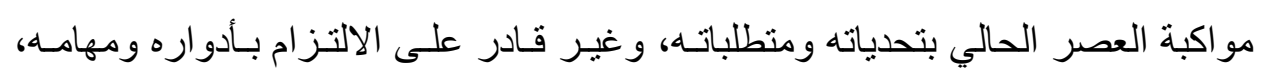

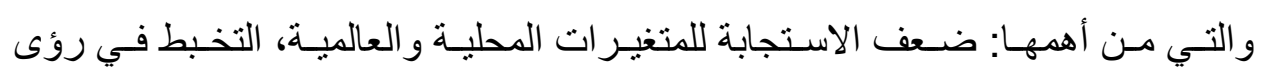

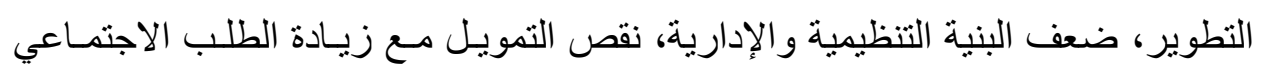

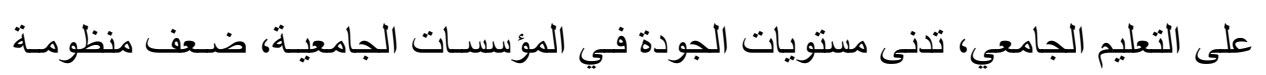
البحث العلمي، ضعف في قدرة خريجي الجامعـات الحكوميـة على المنافسـة في سوق لهون

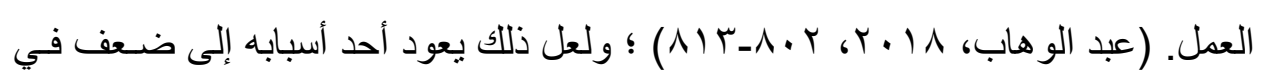
إعداد الخطة الاستر اتيجية للجامعة أو في متابعة تنفيذها.

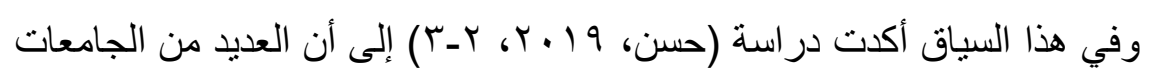
ماز الت غير فاعلة في عملية التخطيط الاستر اتيجي ووضع الخطة الاستر اتيجية السليمة و المتكاملة في ضوء منهجية علمية، أو أن وحدات التخطيط بالجامعات نهتم فقط بترجمـة

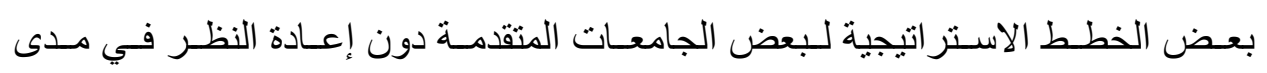

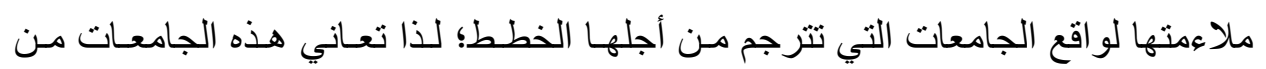

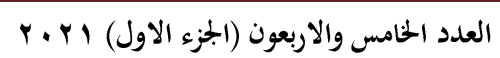

(223)
مجلة كلية التربية- جامعة عين شمس 
استخلام أسلوب بيرت PERT في تخطيط برنامج لتدريب فرق التخطيط الاستراتيجي في

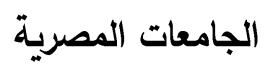

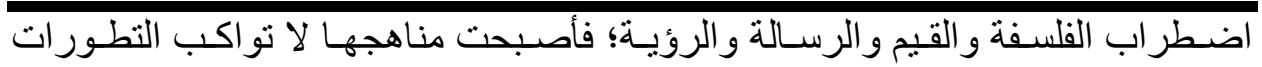
الحديثة وغير مرتبطة بحاجات المجتمع وغير ها من العديد من التحديات التي إن لـم يتم التعامل معها ومو اجنها- من خلال خطة استر اتيجية جيدة وو اقعيـة- فسـوف تـؤثر سـلبًا على مستوى الأداء فيها.

فعلى الرغم من وجود الوحدات المسئولة عن التخطيط الاسـتراتيجي بالجامعـات المصرية، إلا إن منظومة التعليم الجامعي ماز الت تعاني العديد من المشكلات التي تعكس

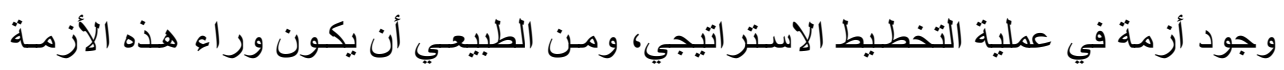
العديد من الأسباب ولعل من أهمها ضعف الكفايات لدى فريق التخطيط الاستر اتيجي ومـن ثم التقصير في القيام بالأدوار المنوطة به. الأمر الذي يتطلب تطوير الكفايـات التخطيطيـة اللازمة لفرق التخطبط بالجامعات للقيام بأدوار ها ومهماتها بكفاءة عالية. r- توفير كوادر بشرية مؤهلة في وحدات التخطيط الاستراتيجي بالجامعات: تواجه عمليات التخطيط الاستر اتيجي للجامعات العديد من المشكلات في عدد من

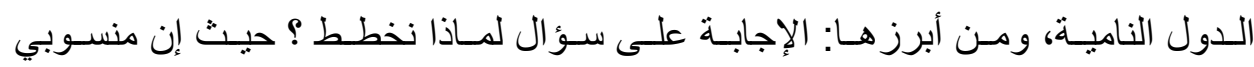

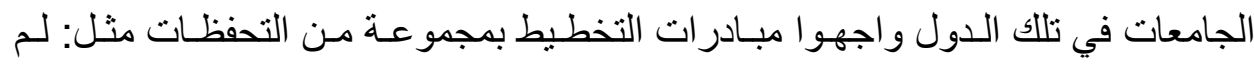
يسبق لنا التخطيط، لا جدوى من التخطيط في حل مشكلات التعليم، التخطيط مسئولية الإدارة العليـا. كمـا أكد على أن أحد العقبـات الرئيسـة هـي بـدهـ عمليـة التخطيط فعليًا،

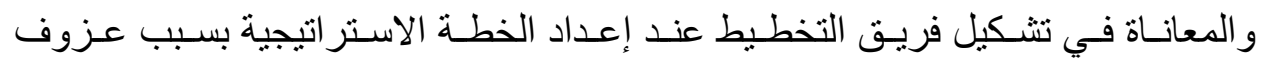
الأعضاء عن العمل في وحدات التخطيط لقلة الخبرة في العطية التخطيطية، ناهيك عن الافتقار إلى القيادات القادرة على أخذ زمام قيادة عملية التخطيط. (آل الثـيخ؛ والثـعيبي،

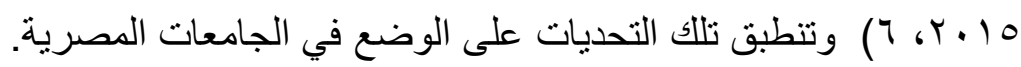
ومن هذا المنطلق يجب أن يكون هناك بر امج تدريبية عاليـة المستوى ومستمرة تركز على مختلف جوانب العملية التخطيطية لتدريب فرق وحدات التخطيط الاستر اتيجي

$$
\begin{aligned}
& \text { العدد الحامس والاربعون (الجزء الاول) ب. r. T } \\
& \text { مجلة كلية التربية- جامعة عين شمس }
\end{aligned}
$$




\section{د/ وفـاء عبد الفتــاح محمـود}

بالجامعات، وتشمل التعريف بخصائص ومو اصفات العمل الذي سيؤديه أعضـاء الفريـق في إطار عملية التخطيط في المستوى الذي يعمل به سواء على مستوى الوحدة المركزيـة للتخطيط أو المستويات الفرعية، و اكساب معارف ومهار ات و إتجاهات جديدة، وصقل مـا هو موجود منها وتتميتها بما يزيد من كفاءة وفعالية الأداء وذلك لتوفير خلفيـة تخطيطيـة و إيجـاد لغــة مشـتركة تكـون مفرداتهــا الأطـر الفكريـة والمنهجيـة و الطـرق و الأسـاليب

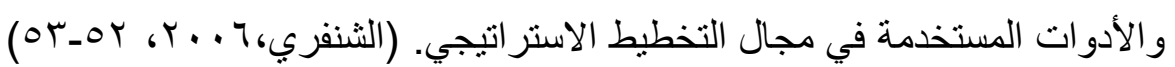
المحور الثاني: الكفايات اللازمة لفريق التخطيط الاستراتيجي والتدريب المبني عليهـا:

(المفاهيم والأطر الفكرية)

يعد التدريب المبني على الكفايات من أهم أنواع التدريب، ومـن أبرز الإتجاهـات الحديثـة في مجـال التـدريب، ويعـد أسـلوب علاجسي في التصـدي لضـعف المعسارف و المهار ات لدى فريق العمل؛ فالتدريب من أهم وأنجح الوسائل في تنمية وصقل المعارف و المهـار ات و الإتجاهـات الإيجابيـة لـدى أعضــاء العمـل وحتى بـأتي التـدريب بالثـــار المرجوه ينبغي أن يتم أولاً تحديد الاحتياجات التدريبية، أي الكفايات المطلوب تتميتها في الفريق وفقًا لظروف وطبيعة عملهم والأهداف المرجوه منهم، ويجب أن بـتم هذا التحديد بكل دقة ثم تأني بعد ذلك عمليـة اختيـار المحتـوى المناسـب للتـدريب و أسـلوبه و القـائمين بالتدريب حتى يمكن تركيز العمليـة التدريبيـة في تتميـة المعـارف والمهـار ات المطلوبـة

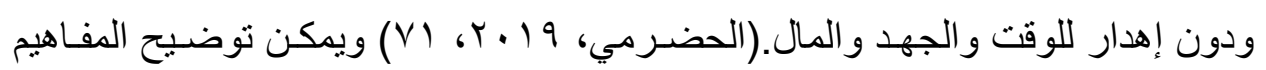
والأطر الفكرية على النحو التالي: 
استخلام أسلوب بيرت PERT في تخطيط برنامج لتدريب فرق التخطيط الاستراتيجي في الجامعات المصرية

\section{أولاً: كفايات فريق التخطيط الاستراتيجي :}

لكى يؤدي فريق التخطيط الاستر اتيجي أدو اره ومسئولياته بإتقان وكفـاءة عاليـة،

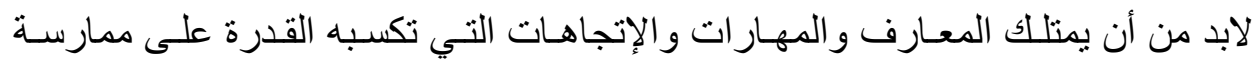
عملية التخطيط الاستر اتيجي لتحقيق رسالة ورؤية وأهداف المؤسسة الاستر اتيجية.

\section{1- الكفاياتC Competencies : المفهوم والأنواع)}

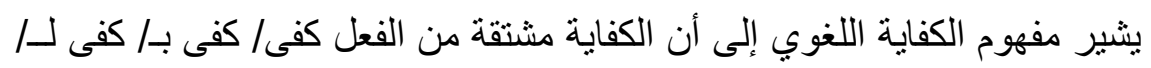

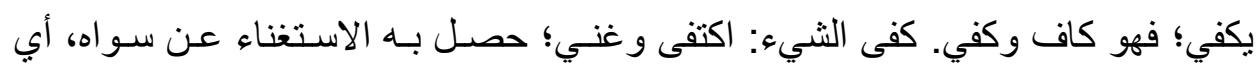

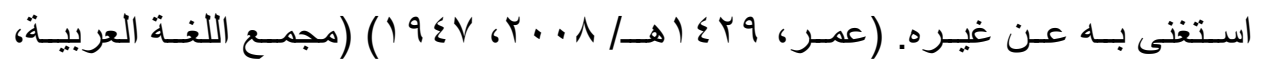

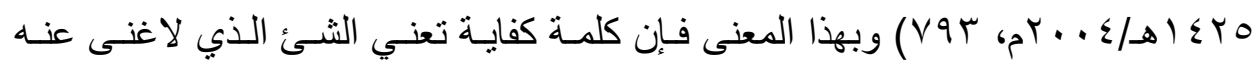
ويكفي عما سواه، وتعني مقدار الحاجة بلا زيادة أو نقص.

ويخلط البعض بين مصسطلح الكفايـة ومصسطلح الكفـاءة إذ إن البعض يعتبر همـا مر ادفان لبعضهما، ولتوضيح ذلك، فإن الكفاية تعني أن الوسائل المستخدمة كافية لتحقيق

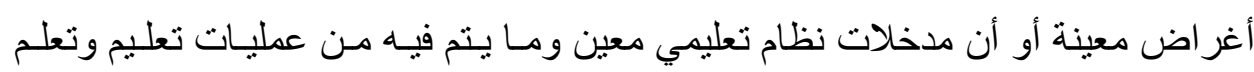
كافية لتحقيق أهدافه المنشودة. أما الكفاءة تعني الحصول على أكبر عائد ممكن بأقل جهد ومال وفي أسرع وقت، أي الحصول على أكبر قدر مـن المخرجـات التعليميـة باسـتخدام

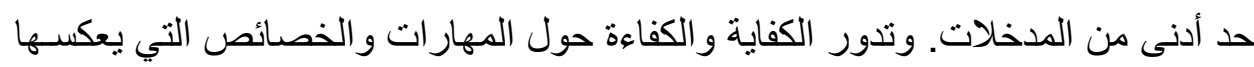
الأفراد في أدائهم للأعمال وفي المو اقف المختلفة، ومدى النجاحات التي يحققونها، ومـع

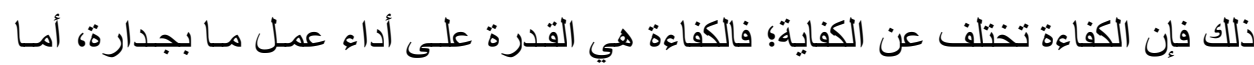
الكفاية فتتعلق بالخصائص و المهارات التي تسـاعد الفرد على الأداء الجيد في الأعمـال

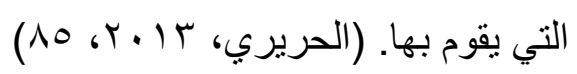

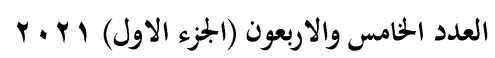

(226)

مجلة كلية التربية- جامعة عين شمس 


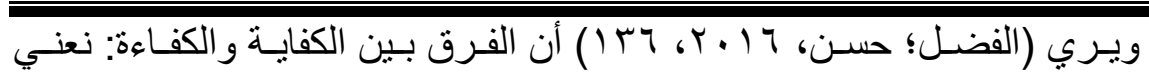

بالكفاية المهار ات والخصائص الثخصـية التـي تكفي لأداء عمـل مـا بثـكل مقبـول، أمـا الكفاءة فهي الحد الأقصى للأداء في ظروف مثالية. وتعرف الكفاية بأنها: قدرة ذات بعد معرفي وبعد أدائي وبعد وجداني تجعل الفرد قادرًا على المبادره نحو العمل؛ فهي المعارف والمهار ات التي يمتلكها الفرد أو تلك التي

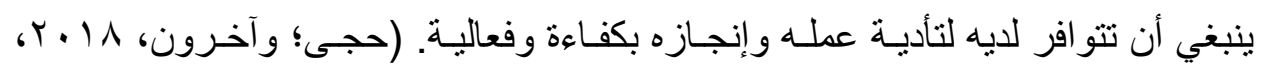

وعرّف (Udoh, 2016, 26) الكفاية على أنها: "القدرة على أداء مهمة محددة

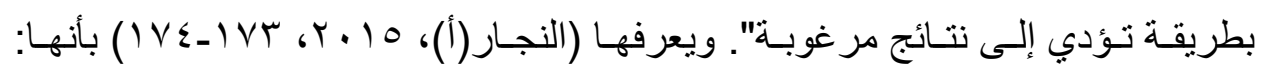
مجمو عة من المعارف و المهار ات والإتجاهات التي يمكن اثـتقاقها مـن المهـام والأدوار التي يقوم بها الفرد، و التي يمتلكها نتيجة لإعداده أو تأهيلـه في برنـامج معين والاسـتفادة منها في مجال ما بهدف تحقيق التقدم فيه. ويعرف (Wagiran, et. al, 2019, 389) الكفايات بشـكل عـام على أنها: خصائص أو قدرات أو امتلاك الفرد معسارف ومهـار ات محددة و التي تمكنه مسن أداء سـلوك معـين بدقـة وكفـاءة عاليـة وبالثـكل الصـحيح، وتشـتمل على الجوانـب المعرفيـة و العاطفية و السلوكية.

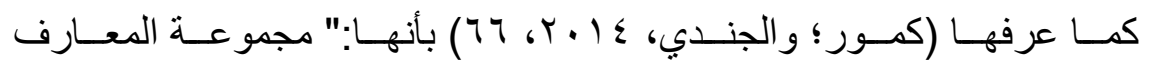
و المهار ات والإتجاهات التي توجه سلوك الفرد و هي القدرة على عمـل شـيء مـا بفعاليـة و إتقان ومستوى معين من الأداء وبأقل جهذ ووقت وكلفة".

والكفايـات في وجهـات نظـر) (Akanwa \& Eluwa, 2014, ) هـي

خصائص أو قدرات معينة للفرد تمكنه من أداء إجـر اءات محددة، كمـا إنهـا تمثنل القدرة التي يجلبها الفرد إلى الوظيفة عندما تتطلـب مسئوليات الوظيفـة عمـل إجـر اعات محددة لتحقيق النتائج المرجوة، ويستمد الفرد من موارده الداخلية القدرة على الاستجابة. 
استخلام أسلوب بيرت PERT في تخطيط برنامج لتدريب فرق التخطيط الاستراتيجي في الجامعات المصرية

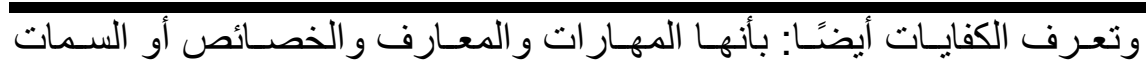

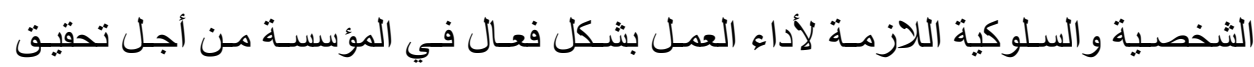

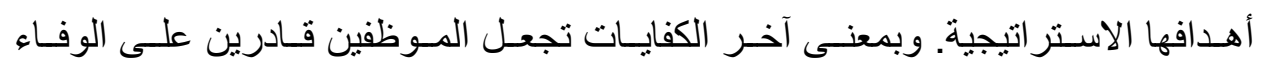

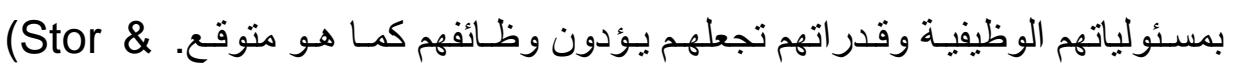
kupczyk, 2015, 51)

وبنـاء على مـا سـبق يمكن تعريـف الكفايـات فـي سـياق ارتباطهـا بـالتخطيط

الاستر اتيجي بأنها: جملة من المعارف و المهارات والإتجاهات التي ينبغي أن تتو افر في لي

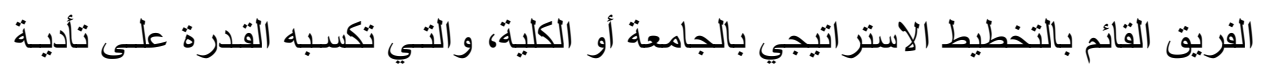
أدواره ومسئولياته بدقة و إتقان وبكفاءة عالية وبأقل جهذ ووقت وتكلفة بالهة

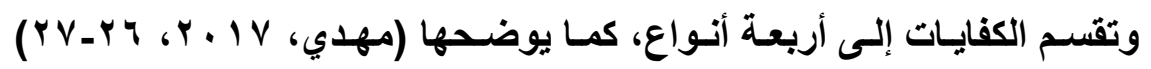

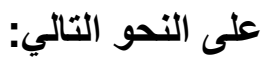

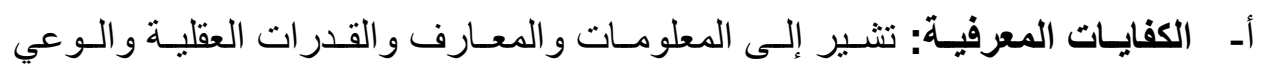

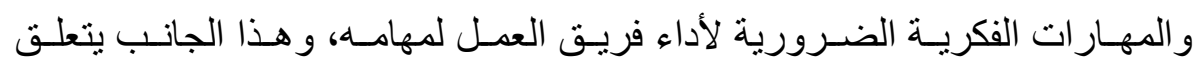
بالحقائق و النظريات والفنيات، ويعتمد مدى كفايـة تلك المعـارف على استر اتيجية المؤسسة في الجانب المعرفي.

بـ الكفايات الأدائية: تشير إلى كفايـات الأداء التي يظهرهـا الفرد، وتتضـمن المهارت النفس حركي، وتعتمد على ما حصله فريق العمل سابقًا من كفايات معرفية. ج- الكفايات الوجدانية: تشير إلى آراء فريق العمل واستعداداته وميولة و إتجاهاته وقيمـهـ

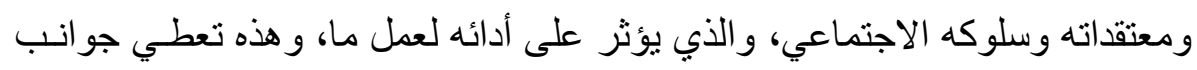
كثيرة مثل حساسية الفرد وتقبله لنفسه و إتجاهاته نحو المهنة.

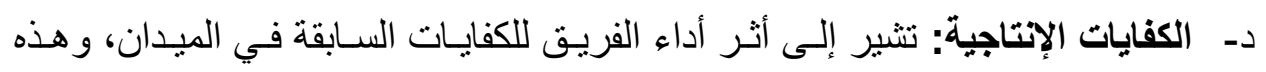
ينبخي أن تَلقي الاهتمام في البرنامج التدريبي. وكثير ما ينظر إلى المستوى الأخير

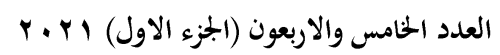

(228)
مجلة كلية التربية- جامعة عين شمس 


\section{د/ وفـاء عبد القتــاح محمـود}

من منظور التقدير والتقويم أي المسـتوى الذي ينبغـي أن يقوم مـن خلالـهـ البرنـامج المبني على الكفايات.

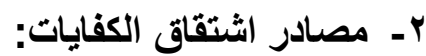

يمكن اشـتقاق الكفايـات اللازمــة لقريـق التخطـيط مـن خـلال المصــادر التاليـة:

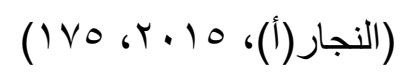

أـ المصدر النظري: الاعتمـاد في اشـتقاق الكفايـات على نظريـة تربويـة مـا وتكـون الكفايات المشتقة تتفق مع مرتكز ات النظرية التربوية.

ب- رصد الأداء النموذجي: أي الملاحظة الدقيقة للأداء النموذجي لفريتق عمـل يثـهد لـه بالكفاءة في مبدان العمل ورصدها بطريقة منظمة للخروج بقائمة من الكفايات. ج- القوائم المرصودة: الاعتماد على قوائم تم إعدادها مسبقًا في المؤسسات المشابهة في المبدان نفسه.

د- براء المهنة: الاعتماد على الخبراء في مجال التخطيط في تحديد الكفايـات الـازم تو افر ها لدى فريق التخطيط الاستر اتيجي. هـ حاجـات الميـان: في ضـوء طبيعـة ميـدان العمل وحاجاتـه تحـدد قياداتـه وخبر ائـه و القائمون على التخطيط به مطالب معينـة لإعداد الفرد الذي سـيعمل في الميدان.

$$
\text { و هذه المطالب تتطلب تحديد كفايات معينة. }
$$

و- تحليل العمل: تحليل المهام والأدوار التي يقوم بها فريق التخطيط الاسـتر اتيجي أثتـاء عمله وتحليل المعارف و المهار ات والإتجاهات المطلوبة لتحقيق مهماته. ويمكن الإشـارة إلى إنه يمكن استخدام أكثر مـن مصسدر في آن واحد، حيـث إن تحديد الكفايات بدقة محور مهم للغاية في رسم الخطـوط العربضـة لبرنـامج تأهيـل فريـق التخطيط الاستر اتيجي. 
استخدام أسلوب بيرت PERT في تخطيط برنامج لتدريب فرق التخطيط الاستراتيجي في الجامعات المصرية

\section{r- قائمة الكفايات الأساسية اللازمة للفريق القائم بالتخطيط الاستراتيجي:}

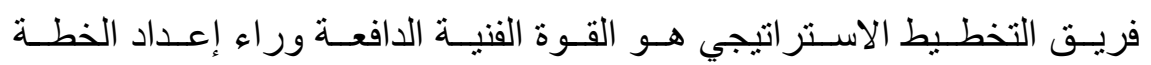

الاستر اتيجية ومتابعة تتفيذها وتقويمها، لن يكون الفريق مسئو لاً فقط عن تنفيذ المهام

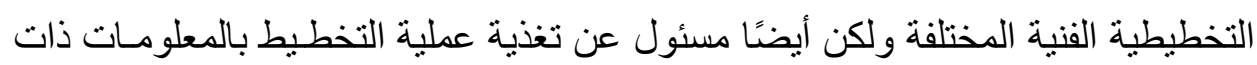

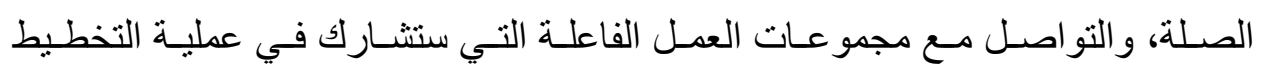
و التنفيذ، مع التوجيه الفني و الدعم اللازمين، بالإضافة إلى بعض المهارات العامة ومنها:

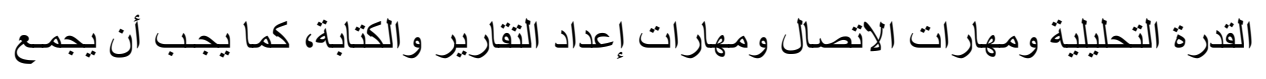
فريق التخطيط الاستر اتيجي بطريقـة أو بـأخرى الكفايـات التقنيـة في المجـالات التاليـة: التحليل الإحصائي بما في ذلك استخدام المؤشرات، اسـتخدام نمـاذج المحاكـاة المحوسبة، تقدير التكاليف والتمويـل. (Unesco(B), 2010, 8) ومـن ثم تتعدد الكفايـات التي يجب أن تتو افر في فريق التخطيط الاستر اتيجي بالجامعـة والكليـات، وتتنـوع فيمـا بينها، يمكن الإشـارة إلى أبرز هذه الكفايات في ضو فو مسح وتحليل العديد من البحوث التربويـة

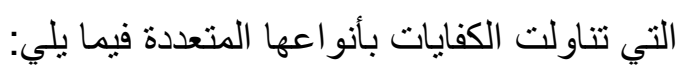
أ- الكفايات التخطيطية الفنية:

يعتبر التخطط الاستر اتيجي عملية يتم من خلالها تحليـل الواقع الحسالي للمؤسسـة

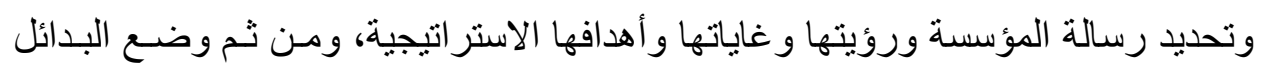
الاستر اتيجيات واختيار الاستراتيجية المناسبة مع الإمكانيات المتاحة ووضـع الإجـراءات المخططة بشأن تتفيذها ومتابعتها وتقويمها، وصو لاً بالمؤسسة إلى ما تريد أن تكون عليه الإسه الإسيه في المستقبل. لذلك فإن الفريق القائم بالتخطبط الاستر اتيجي بالجامعة أو الكلية في حاجـة إلى جملة من الكفايات التخطيطية الفنية التي تعينه على القيام بهذه المهام. ويقصد بالكفايات الفنية: المعرفة المتخصصة في فرع مـن فروع العلم و الكفـاءة

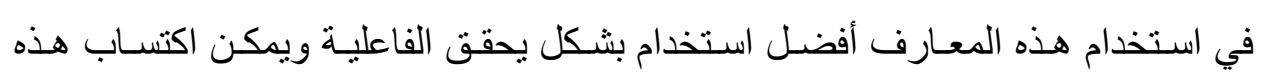

$$
\begin{aligned}
& \text { العدد الحامس والاربعون (الجزء الاول) ب. r. T } \\
& \text { مجلة كلية التربية- جامعة عين شمس }
\end{aligned}
$$


الكفايات عن طريق الدراسة والخبرة والتدريب. و هي فهم متطلبـات العمل الذي يشـرف عليه الفرد والأسس العلمية التي يستند إليها فينبغي على رئيس العمـل الإلمسام بالمعـارف

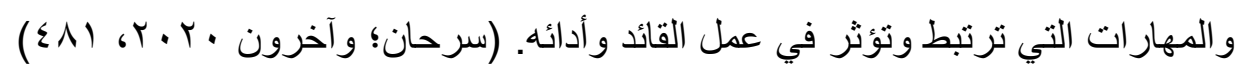
وتعرف كفايات التخطيط الاستر اتيجي بأنها: هي مجمو عة المعارف و المهار ات التي يمتلكها القيادات والتي تكسبهم القدرة على ممارسـة التخطيط الاسـتر اتيجي وتمكنهم من أداء مهامهم ووظائفهم بصورة أكثر فعالية، لتحقيق رسالة ورؤيسة وأهداف المؤسسـة

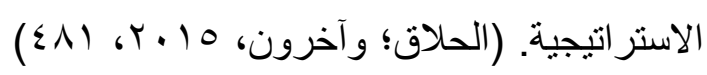

ويقصــد بالكفايـات المعرفيـة و المهاريــة للتخطـيط الاسـتر اتيجي القـدرات التـي يكتسبها الأفر اد من خلال التدريب والخبرة والتي تتصل بكل مكونات ومر احل التخطيط

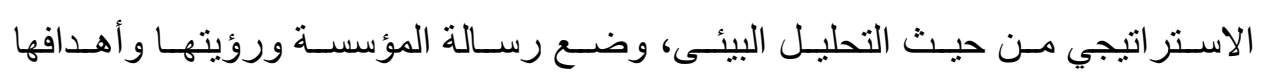
الاستراتيجية، إجراءات وخطو ات التنفيذ، كذلك قياس ومتابعة وتقييم الأداء الاستر اتيجي، حيث إن هذه الكفايـات تخدم الأهداف التي تسـعى المؤسسـة إلى تحقيقهـا عبـر خطتهـا

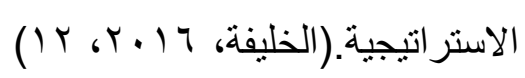

ويثـير (Lugemwa, 2014, 80) إلىى أن مهـار ات التخطيط الاسـتر اتيجي

تتمثنل في مهـارة تحديــ الرسـالة والرؤيـة و الأهـداف، ومهـارة وضـع الاسـتر اتيجيات المناسبة، ومهارة صياغة الخطـة الاسـتر اتيجية لتحقيت هذه الرؤيـة و الأهداف، ومهـارة متابعة وتقييم الخطة الاستر اتيجية. وبالتـالي، فـان الكفايـات التخطيطيـة الفنيـة هـي التـي تتعلـق بمنهجيـة التخطيط الاستراتيجي التي يجب أن يمتلكها الفريـق القـائم بـالتخطيط في الجامعـة أو الكليـة؛ فهي معسارف ومهـار ات تخصيصـية دقيقة يكتسبها الفريـق مـن خـلال التدريب المبنـي على الكفايات و عملية الممارسة داخل بيئة عمل محفزة و التنمية المهنيـة الذاتيـة، و التي تكسبه القدرة على القيـام بـأدواره ومسئولياته. و عليـه تتحـدد قائمـة الكفايـات التخطيطيـة الفنيـة الرئيسة في:

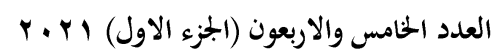

(231)
مجلة كلية التربية- جامعة عين شمس 


\section{استخدام أسلوب بيرت PERT في تخطيط برنامج لتدربب فرق التخطيط الاستراتيجي في الجامعات المصرية فيطاية}

كفايات التحليل البيئى للمؤسسة.

كفايات صياغة رسالة ورؤية المؤسسة. كفايات تحديد الغايات و الأهداف الاستر اتيجية.

كفايات صباغة الخطة الاستر اتيجية.

كفايات صياغة الخطط التنفيذية.

كفايات المتابعة و التقويم للخطة الاستر اتيجية و الإعداد للخطة الجديدة.

ويتم التوصـل إلى هذه الكفايـات بالتفصيل مـن خـلال تحليـل أدوار ومسئوليات

فريق التخطيط الاستر اتيجي. وسوف تعرض قائمة الكفايـات التخطيطيـة الفنيـة بالتفصيل في المحور الثالث من البحث الحالي كأهداف للبرنامج التدريبي المقترح. ب- الكفايات البحثية والإحصائية:

يعتبر البحث العلمي عملية تقصي منظمة؛ باتباع أسـاليب ومنـاهج علميـة محددة

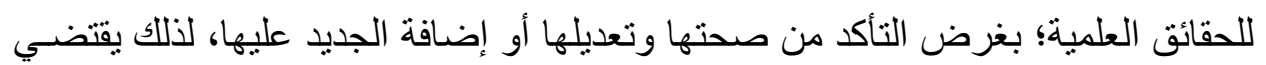
أن بمتلك الباحث العلمي معارف ومهار ات بحثية تتجلى في توظيف أدوات البحث العلمي لمعرفة الحقيقة، والقدرة على التحليل و التفسير و النقد و الاستتناج و اتخاذ القرار، وتوظيف

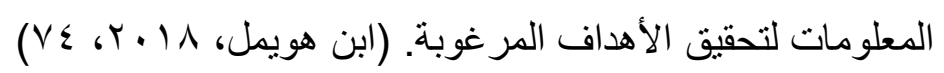
وبالتالي، فإن الكفايات البحثية و الإحصـائية تتعلق ببر اعـة و إتقان ونجـاح فريق التخطيط الاستر اتيجي كباحثين في استخدام أساليب و أدوات البحث العلمي في التعامل مـع المشكلات التي تواجه النظام التعليمي وعلاقتها بنظـام المجتمع ككل، وجمـع المعلومـات وتحليلها وتقييمها لحل موضوع ما وفقًا لمهار اته وخبر اته البحثية التي اكتسبها مـن خـلال الإعداد التربـوي؛ وذللك حتى يستطيع أن يضـع خططًا علميـة وإجر ائيـة تتسـم بـالجودة و الثقة في معطياتها، ونتائج تتفيذها. و عليه تتحدد قائمة هذه الكفايات في: 


\section{د/ وفــاء عبد الفتــاح محمـود}

تصميم الأدوات لجمع البيانات و المعلومات المتعلقة بالبيئة الداخلية و البيئة الخارجيـة مبـة

للمؤسسة.

القدرة على استخدام الأساليب الإحصائية المختلفة وطرق معالجة البيانات.

التمكن من استخدام الأسلوب العلمي في كتابة الخطة.

القدرة على تحديد الأولويات التعليمية وترتيبها حسب أهميتها.

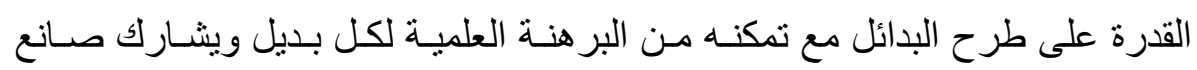
القرار في اختيار البديل المناسب في ضوء نتائج البحوث التربوية.

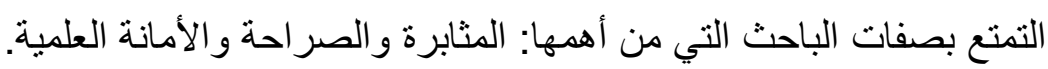

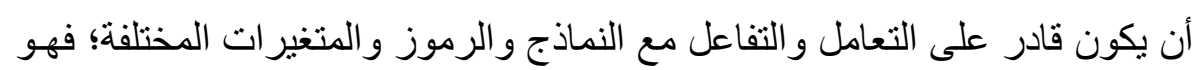

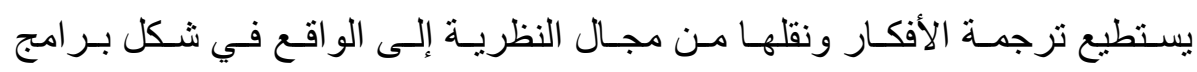

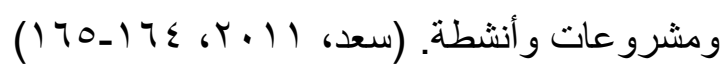

القدرة على تحديد أهداف الخطة الاستر اتيجية تحديدًا دقيقًا. الإلمام و البحث ومعرفة كل جديد في مجال التخطيط الاستر اتيجي. القدرة على استخدام بر امج التحليل الاحصائيsspss لإدخال البيانات وتحليلها. القرة على إدر الك وفهم وتقويم الدلائل العلمية. القدرة على تحليل وتقسير ونقد المعلومات. القدرة على إحداث تكامل بين البيانات المتفرقة.

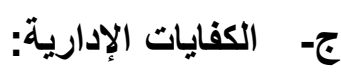

يقصد بالكفايـات الإداريـة مجموعـة المعـارف والأسـاليب و المهـار ات والخبـرات

التي ينبغي أن يمتلكها أو يسعى إلى توظيفها أوتحقيقها من قبل رؤساء العمل من أجل أن أن تؤ هلهم للوصول إلى المستوى المطلوب للنجاح في عملهم. (الجبوري، (1) ـ ب، 9 (1) كما تعرف الكفايات الإدارية بأنها : "مجموعة مـن المهار ات و والمنطلبـات التي عي التهي

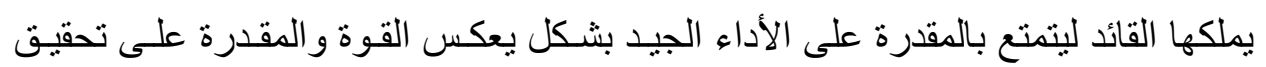


استخدام أسلوب بيرت PERT في تخطيط برنامج لتدريب فرق التخطيط الاستراتيجي في الجامعات المصرية

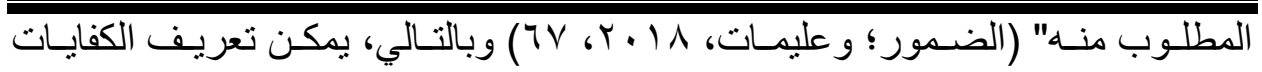
الإدارية بأنها: مجمو عة المعارف و المهارات و التي ينبغي أن تتو افر لاى رؤساء الغايـات (الفريق القائم بالتخطيط) في الخطة الاستر اتيجية ليتمكنوا من القيام بمهماتهم.

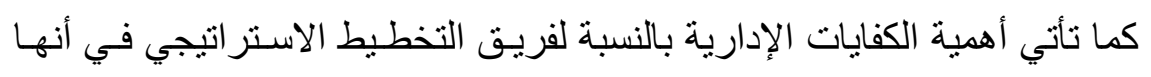
تؤُثر في تنفيذ الخطة؛ لأن عمل الفريق يمتد إلى أجز اء مختلفة من النظسام التربوي مثنل:

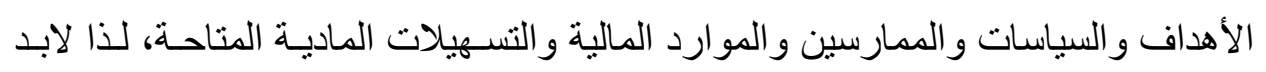

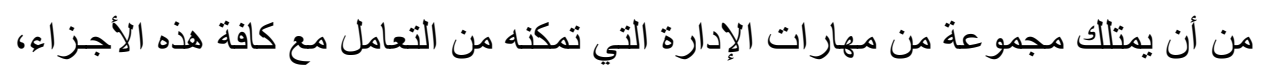

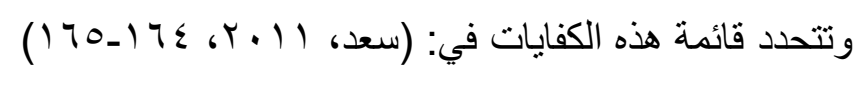
• الإلمام ببعض المفاهيم الإدارية الأساسية المعاصرة. • الإلمام بالتشريعات و اللوائح المنظمة لعملية التخطيط و إدار اتها. • القدرة على صنع القرار وحل المشكلة. • مهارة التنسيق و الترتيب و التنظيم. هالقدرة على العمل في فريق، ومواجهة و إدارة الأزمات. القدرة على نطبيق الأساليب الرقابية المختلفة. مهار ات الاتصال و العلاقات الثخصية. الذكاء الاجتماعي و التعامل مع النوعيات المختلفة من الأفر اد. تحديد الأهداف والأنشطة و العمليات الإدارية التي تحقق أقصى كفاءة. تقويم الأداء المؤسسي و علاقته بوضع الأهداف. التوجيه عن طريق تقدير الوقت التفصيلي للخطة وإمداد القادة بالمعلومات عن تنفيذ الخطط حتى يكونوا قادرين على صنع القرار. المشاركة في نوزيع بنود الميزانية على أنشطة الخطة. المتابعة الدورية للخطة أثناء تنفيذها، التقويم و التصحيح المتتالي.
العدد الخامس والاربعون (الجزء الاول) بr.r
(234)
مجلة كلية التربية- جامعة عين شمس 
الالتز ام و التعهر بخدمة المصلحة العامة.

الالتزام بالإتقان في العمل وكفاءة الأداء.

تشكيل فريق العمل المتجانس.

توزع المهام بين أعضاء الفريق مع مر اعاة التخصصات و والقدرات.

د- الكفايات التكنولوجية:

تعد الكفايـات التكنولوجيـة مطلب أسـاس في الحيـاة المعاصـرة لأنسه لا تطسوير

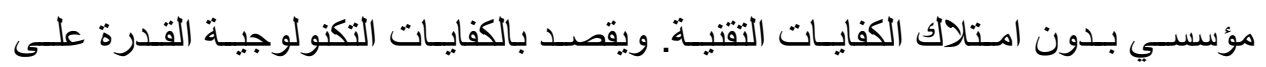
الوصول إلى المعلومات بدقة، القدرة على تحليـل المعلومـات واختيار هـا بكفـاءة، القدرة على تتظيم المعلومـات بالثـكل المناسـ، القدرة على اسـتخدام المعلومـات ونوصـيلها

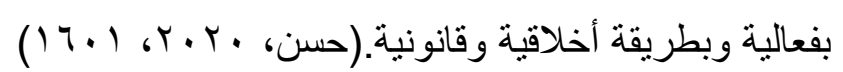

كما تعرف بأنها: المعارف والمهار ات والإتجاهات التي تتعلقف بالتقنيات الحديثة التهنة التي ينبغي أن تتو افر لاى الفرد و التي تمكنه من معرفة بـر امج التقنيـة الحديثـة وتوظيفهـا

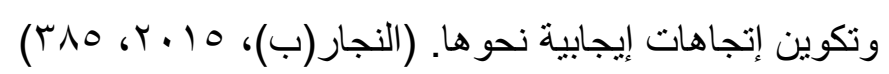

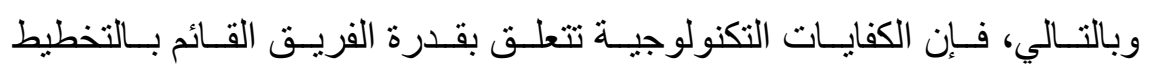

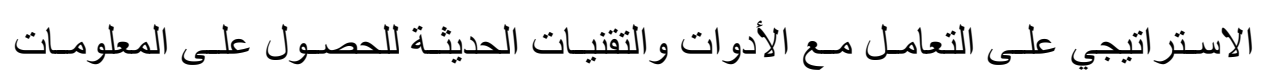

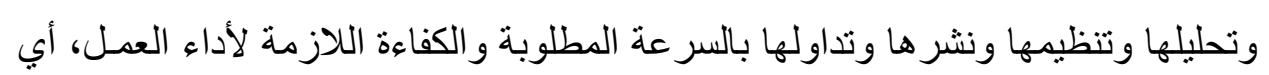

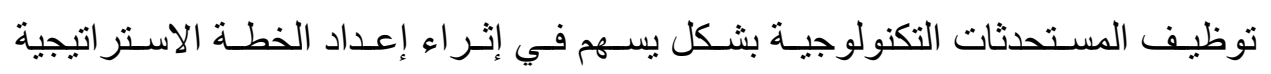
ونشر ها ومتابعة تتفيذها وتقويمها. ومن ثم تتحدد قائمة هذه الكفايات في: توظيف الوسائط التكنولوجية في متابعة تنفيذ الخطة الاستر اتيجية وتقويمها. • القدرة على عمل مدونة إلكترونية لنشر الخطة الاستر اتيجية. • القدرة على التعامل مع نظام المتابعة الالكتروني. القدرة على تحليل ومعالجة البيانات و المعلومات باستخدام الوسائط الرقمية. التعامل مع نظام الأرشفة الإلكترونية لحفظ الوثائق و الأدلة.

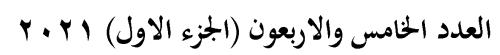

(235)
مجلة كلية التربية- جامعة عين شمس 


\section{استخدام أسلوب بيرت PERT في تخطيط برنامج لتدربب فرق التخطيط الاستراتيجي في الجامعات المصرية}

$$
\text { ه إنثاء السجلات الإلكترونية للصـادر و الوارد واجتماعات الوحدة. }
$$

إدارة موقع إلكتروني لوحدة التخطيط على شبكة الإنترنت.

التعامل مع شبكة المعلومات الدولية الالكترونية المتخصصة في مجال التخطيط.

$$
\text { هـ الكفايات الثخصية والإنسانية: }
$$

" يقصد بالثخصية هنـا مجموعـة الصـفات الجسمية و الانفعاليـة و العقليـة للفرد و التي تؤثر منفردة أو مجتمعة في سلوك الآخر كما يكون لمظاهر هـا المختلفـة تـأثنير في

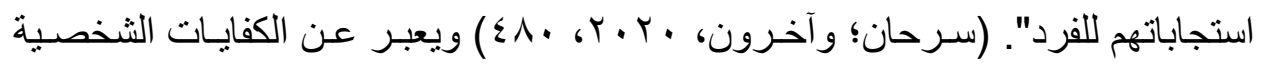
بالاستقامة في السلوك وحسن السيرة و الخلق و الاتزان النفسي والاتصـاف بالحكمـة والثقـة

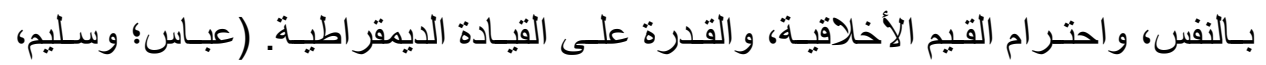
(r) $\leqslant 6 \cdot 19$

وتتعلق الكفايات الإنسانية بالطريقة التي يستطيع بها مسئول الإدارة التعامل بنجـاح مع الآخرين، ويجعلهم يتعاونون معه ويخلصون في العمل ويزيد من قدر اتهم على الإنتاج

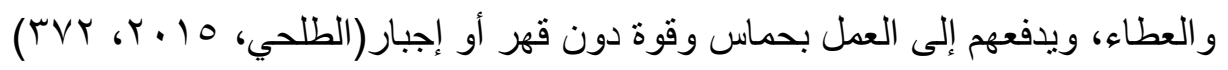
ومن ثم تعني الكفايـات الثخصية والإنسـانية مجموعـة السـمات و الصفات التي التي يجب نو افر ها في الفريتق القائم بـالتخطيط الاسـتر اتيجي، وقدرة رؤســاء غايـات الخطـة الاستر اتيجية على التعامل مع المرؤوسين (فريق العمل) وتتسيق جهودهم و إيجـاد روح العمل الجماعي و الثقة و الاحتر ام المتبادل بينهم و هذا يتطلب امتلاك رئبس الغايـة سمات شخصية تجعله محبوبًا لدى فريق العمل معه ووجود فهم متبـادل بينه وبينهم، ومعرفته لآر ائهم وميولهم و إتجاهاتهم. و عليه تتحدد قائمة هذه الكفايات في: • القدرة على التعامل و التفاعل بإيجابية مع الآخرين. النضج الاجتماعي لتكوين العلاقات الإنسانية.

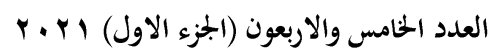

(236)
مجلة كلية التربية- جامعة عين شمس 
إيجاد جو من التنافس الهادف بين فريق العمل.

إدر الك إتجاهات فريق العمل.

الطلاقة اللغوية والتعبير الواضح.

التواضع بالتعامل مع الآخرين.

النقد الموضو عى البناء والتوجيه الذاتي.

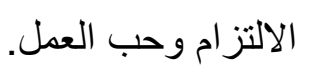

التجديد والإبتكار وصنع القرار.

• التمتع بالثقة بالنفس.

• التحلى بالصبر في المواقف المتنوعة.

• حسن استثمار الفرص. بال.

العمل على تعزيز روح المبادرة و الأصالة.

قوة الملاحظة و القدرة على القيادة.

احتر ام آراء الآخرين.

مر اعاة الظروف الثخصية لفريق العمل.

هالتمسك بالقيم و المبادئ الدينية.

الموضو عية والأمانة الفكرية.

القدوة الحسنة و العدالة.

الانضباط وتحمل المسئولية.

بعد العرض السابق عن الكفايات اللازمة للفريـق القائم بـالتخطيط الاستر اتيجي؛

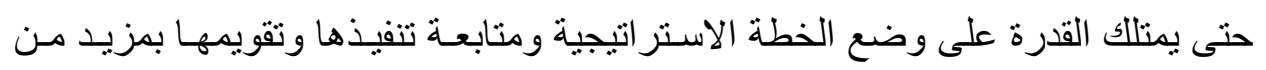

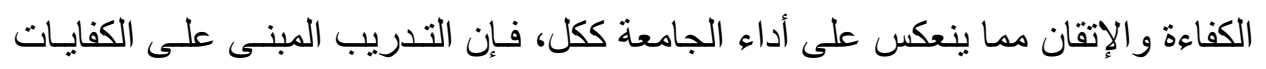
التخطيطية الفنية من أحد وأهم العناصر التي تزود فريق التخطيط الاستر اتيجي بالجامعـة

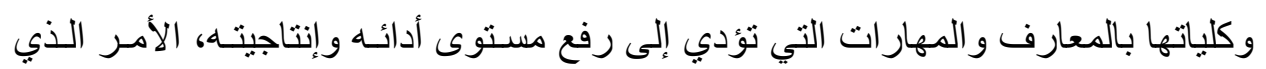

$$
\begin{aligned}
& \text { العدد الخامس والاربعون (الجزء الاول) ب. r. }
\end{aligned}
$$

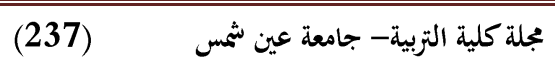




\section{استخدام أسلوب بيرت PERT في تخطيط برنامج لتدربب فرق التخطيط الاستراتيجي في الجامعات المصرية}

يتطلب تقديم برنامج متكامل المحتوى التدريبي لتطوير كفايـات التخطيط الاسـتراتيجي، ووضع البرنامج موضع التنفيذ و التقويم. وحتى يتسنى تصـميم وبنـاء البرنـامج التدريبي المطلوب لفريق التخطيط لابد من معرفة وفهم وتحليل منظومة التدريب. ثانيًا: التدريب المبني على الكفايات: (الماهيةـ المنظومة) يهدف التدريب في الأساس إلى تمكين الفـرد مـن تعزيز وصـل المهار ات في الجو انب النظرية أو العملية في مجـال معين، ويكون ذللك مـن خـلال تـوافر جملـة مـن المعارف التي تسهم في اكسابه جوانب مختلفة من التعلم المتصل بهذا المجـال. لذللك من الضروري أن تكون البر امج التدريبية المبنية على الكفايـات شـاملة في تغطيـة الجو انب

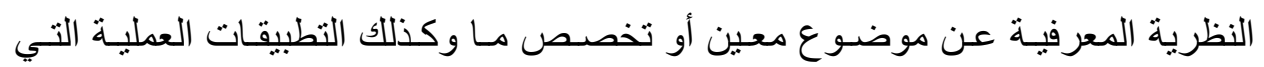

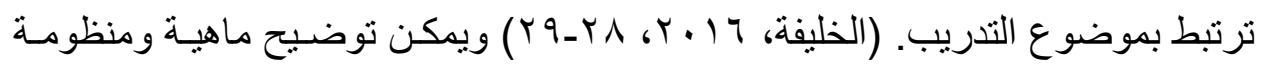
التدريب على النحو التالي: 1- إ - مفهوم التدريب وأهميته:

بعتبر التدريب عمليـة تعليميـة متخصصـة وموجهة بهدف اكسـاب المتدرب المعرفة المتخصصة في مجال معين، بهدف رفع الكفاءة إلى أقصى درجة تنافسية؛ وأي تعليم ينطوي نجاحه على نوع أو أكثر من التدريب الموجه، والتدريب هو عملية اكسـاب

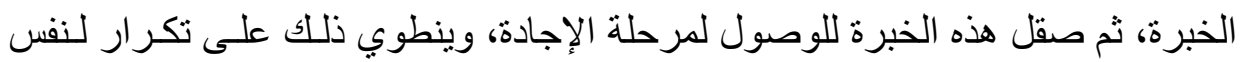
الأداء، ولكن في كل تكر ار تحدث إضافة جديدة، والتدريب عادة لا يكون على اكتسـاب المعرفة فحسب، ولكن يجب أن يصاحب المعرفة التدريب على المهار ات؛ فالتميز يتحقق نتيجة لتعلم المهار ات المهنيـة أو العمليـة، ويصـاحبها المعرفـة المرتبطـة برفع كفـاءات تنافسية محددة، ويحدد للتدريب أهداف محددة لتحسين قدرات المتدرب الأدائيسة واتسـاع

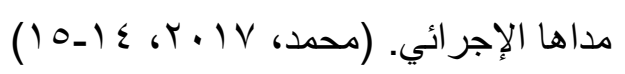

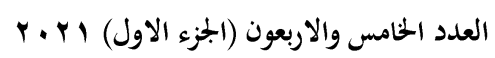

(238)

مجلة كلية التربية- جامعة عين شمس 


\section{د/ وفـاء عبد الفتــاح محمـود}

ويعرف التدريب بأنسه عمليـة مخططـة ومسـتمرة تهدف إلىى تلبيـة الاحتياجـات التدريبية الحالية والمستقبلية لـدى المـوارد البثـرية، مسن خـلال زيـادة معارفهـا وتحسـين مهار اتها وتدعيم إتجاهاتها، بما بساهم في تحسين أدائها في العمل وزيـادة الإنتاجيـة في

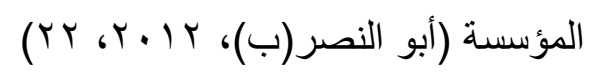

وتظهر أهميـة التدريب في تنميـة وتطـوير وتجديـد معـارف ومهـار ات القـائمين بالعمل ورفع مستوى أدائهم كمًا وكيفًا، ولكي ينجح التدريب في تحقيق أهدافـ؛ فلابـد أن يستند إلى خبرة الأفر اد ومهارتهم، وينبع من أيديولوجية المجتمع المحيط، وبـللك فأهميـة التدريب تتمثل في تتمية عقول المتدربين وتوسيع آفـاقهم ومـداركهم بمـا يسـاعدهم على عمق الفكر ويكسبهم الإدر الك للكثـف عن الآثار المترتبـة على تصـرفاتهم، و التدريب يعمل علي إحداث تكامل بين عملية الإعداد والتأهيل ونوافر فرص التزويـد بالمستجدات

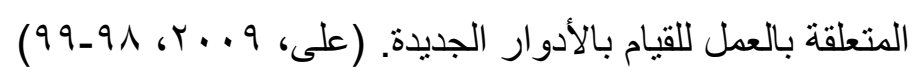
كما إن أهمية التدريب لا تقتصر على تطوير قدرات فريق العمل مـن خـلال تلك المعارف و المهار ات المرتبطة بأداء العمل فقط و إنمـا تمتـد تلك الأهمبـة لتشـمل تحسـين وتطوير سلوكيات فريق العمل وتعاملهم مع المؤسسة ومع الزملاء والرؤسـاء وجمهور المؤسسة، بمعنى أن التدريب هنا يفيد في ترشيد الأنماط والعادات السلوكية وتطوير القيم و الإتجاهات النفيسة لفريق العمـل و التي تكفل لهم المحافظـة على تـوازنهم النفسـي بمـا يؤدي إلى رفع روحهم المعنوية وزيادة إنتاجيتهم، ومن هنا نلاحظ أن أهمية التدريب تمتد لكي تشمل المؤسسة ومجمو عة العمل. المؤسسة تستفيد من التدريب باعتبـار أن التدريب يهدف في النهاية إلى تحسين وتطـوير قدرات القـائمين بالعمـل وتحسـين أدائهـم ومـن ثـم تحسـين وتطـوير وزيــادة إنتاجيـة المؤسسـة، و الموظـف المتـدرب يسـتفيد مـن التـدريب باكتسابه لمعارف مهار ات جديدة تزيد من قدراته على أداء عمله الحالي وهو الأمر الذي يكسبه ميزة مادية ومعنوية فضلاً عن زيادة قدرتهـ على أداء الأعمـال المسـتقبلية و إتاحسة 
استخدام أسلوب بيرت PERT في تخطيط برنامج لتدريب فرق التخطيط الاستراتيجي في الجامعات المصرية فيطاية

الفرص أمامه للترقي لمناصـب ووظسائف أعلى في مستقبل حياتـه الوظيفيـة. (صديق،

$(\mathrm{VT}, \mathrm{r} \cdot) \mathrm{H}$

وبالتالي، التدريب عملية منظمة تهدف إلى تتمية وتطوير الكفايات اللازمة للعمل

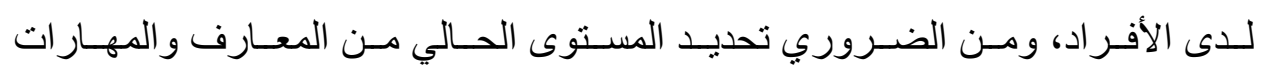
و الإتجاهات في مقابل المستوى المرغوب، والأنشطة التي يمكن من خلالها الوصول إلى هذا المستوى المرغوب، وذلك من أجل الوصول إلى أداء فريق العمل الذي يحقق أهداف المؤسسة و الميزة التنافسية.

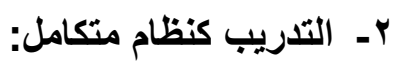

تعد المنظومة كيان فكري أو مادي محدد بمجمو عة مـن المـوارد البشـرية و غير

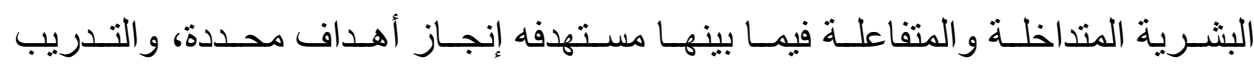
كمنظومة يتكون من مجموعة من المدخلات، و عمليات تفاعل هذه المدخلات مـع بعضـها

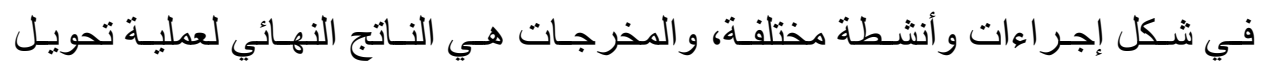

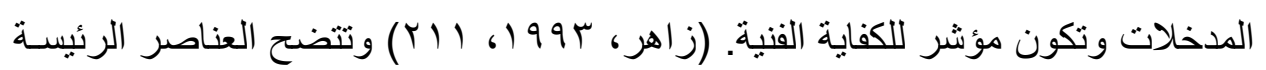

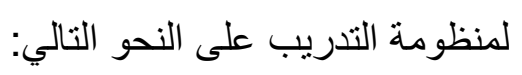

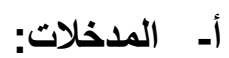

تللك العناصر التي ير اد إخضاعها لعمليات محددة لتحويلها إلى إضـافة خصـائص

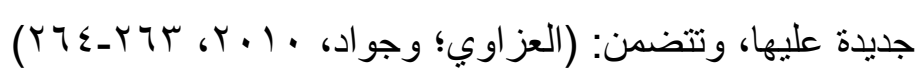
أ/ا : المــخلات البشـرية: تتكـون مسن كافـة الأفـر اد في عمليـة التـدريب مسن متـدربين

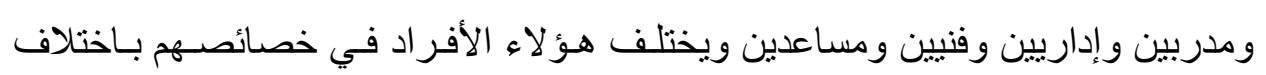

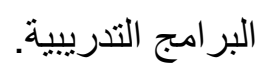
أرب: المدخلات المالية والمادية: وتشمل المخصصات المالية للإنفاق على التدريب من

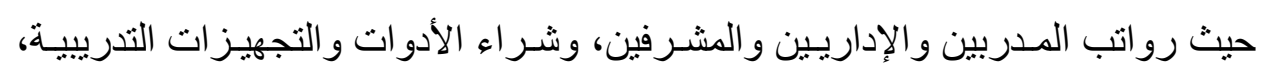




\section{د/ وفــاء عبد القتــاح محمـود}

وكذلك الموارد المالية التي يمكن من خلالها توفير بعض المدخلات المادية الأخرى مثل

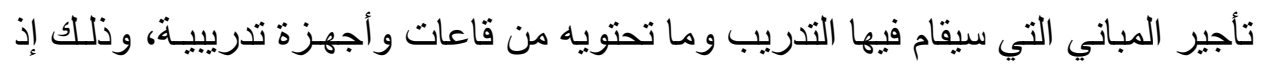
لم تكن منوفره لاى المؤسسة أرب: المــخلات المعلوماتيـة: وتشــل البيانـات الخاصـة بالمنشـأة مسن حيـث أهـدافها، و السياسات و التشريعات والقوانين التي تحدد المسئوليات، و المشكلات التـي تصـادفها، و هذ البيانات لها أهمية كبيرة خاصة إذا كان المتدربون في منشـأة واحدة ويـر اد تدريبهر على كفايات محددة، وتشمل أيضًا المواد التدريبية التي تعرض على التى المتدربين، وبيانـات

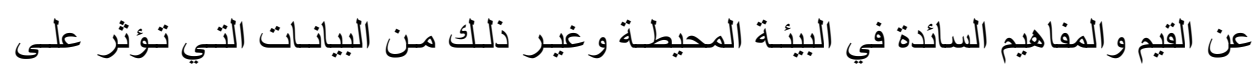
المتدرب و المدرب و العملية التدريبية.

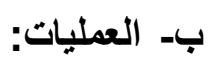

تتم العمليات داخل منظومة التدريب على مر احل، و التـي من خلالها يتم تسيير

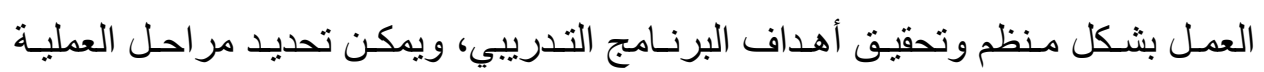
التدريبية في أربع كالتالي: ب/ إ: تحديد الاحتياجات التدريبية: تعرف الاحتياجات التدريبية بأنها: "جملة التغيرات المطلوب إحداثها في معسارف

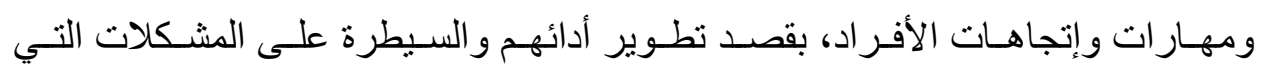

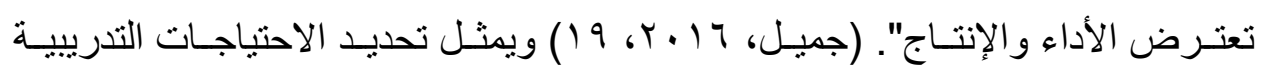
العنصر الرئيسي في تصميم التدريب حيث تقوم عليه جميع ركائز العطلية التدريبيـة، وإن

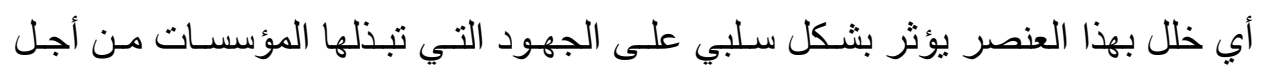

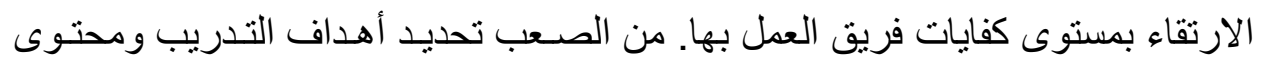
البرنامج والأسلوب الذي يمكن أن يقدم به التدريب بدون التحديد الموضو عي للاحتياجـات

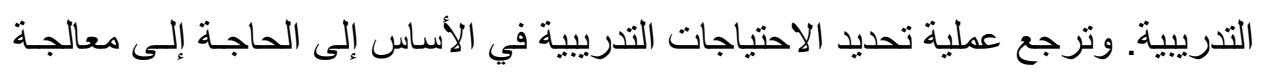

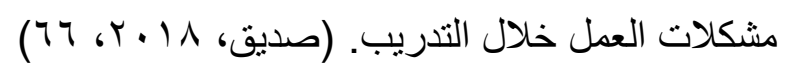

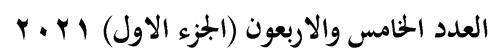

(241)
مجلة كلية التربية- جامعة عين شمس 


\section{استخدام أسلوب بيرت PERT في تخطيط برنامج لتريب فرق التخطيط الاستراتيجي في الجامعات المصرية فيطاية}

وتحليل الاحتياجات التدريبية هو عملية فحص العمليات الحالية والمتوقعة وكذلك

فريق العمل اللازم لتتفيذها وذلك لتحديد حاجة هذا الفريق من التدريب أو إعادة التدريب.

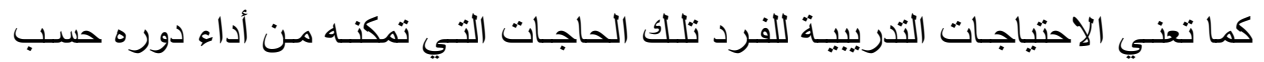

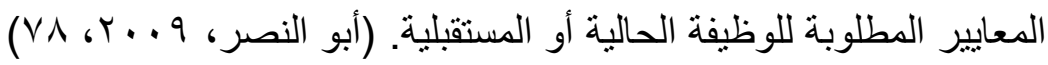
كذلك فإن عملية تحديد الاحتياجات تـتم بنـاءً على عمليـة تحليـل المهام المختلفـة لفريق التخطيط والكفايات المطلوبـة لأداء تلك المهام، وواقع عمليـة تقيـيم الأداء لفريـق العمل بحيث يتم معرفة جو انب القصور لديه وما هي الاحتياجات التدريبية التي يحتاجها

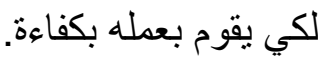
و هنا يجب التأكيد على أن الاحتياجـات التدريبيـة لا تقتصـر فقط على جوانب الخلـل أو القصـور، ولكنهـا تمتـــ أيضًا إلىى جو انـب تطويريـة معينـة. فهـي بـذلك تعنسي

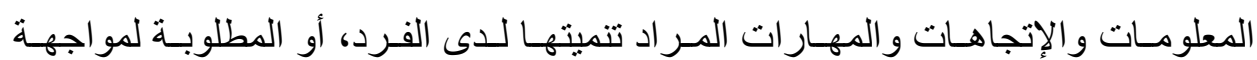

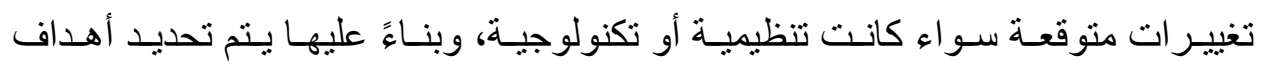
البرنامج التدريبي. (أبو النصر ، 9 . . Y، ع ^) ويمكن تحديد ثلاث مصادر لتحديد وتحليل

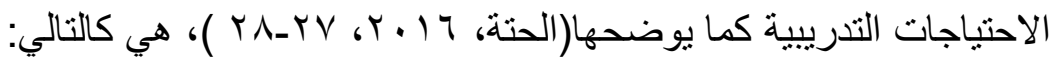
تحليل التظظيم: يتم دراسة المؤسسة من حيث أهدافها الحاليـة والمستقبلية، و الهيكل التنظيمي لها، وكفاءتها، وتحليل المناخ التنظيمي. تحليـل العمـل: يـتم تحليـل المههـات التـي يؤديهـا فريـق العهـل مـن حيـث واجباتـهـ ومسـئولياته وظـروف أدائسه، و المعسارف و المهـار ات والإتجاهـات اللازمــة لأدائـه، ومعايير الأداء المطلوب تحقيقها. تحليل الفرد: يتم في هذا المستوى تحليل مدى قيام الفريق بأداء واجبـات ومسئوليات وظيفته، وذللك لتحديد المهار ات والمعارف وسلوكيات العمل اللازمـة لتطوير أدائـه، 


\section{د/ وفــاء عبد القتــاح محمـود}

وبالتالي فإن هذا الأسلوب يستهدف الفريق نفسه، ويتم بعدة وسـائل أهمهـا الملاحظة

ومراجعة تقارير تقييم الأداء، ومر اجعة سجلات فريق العمل.

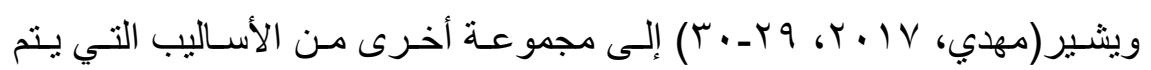

استخدامها في تحليل الاحتياجات التدريبية، وأهمها:

• الاستبانة: وهي استمارة بها أسئلة لتحديد الاحتباجـات التدريبيـة لفريـق العمل وذلكـيك من خلال إجاباته. المقابلة: تكون بشكل شخصي ومبانشر مع فريق العمل ذوبي الاحتياجـات التدريييـة، وتوجيه أسئلة مباشرة للتعبير عن احتياجاته.

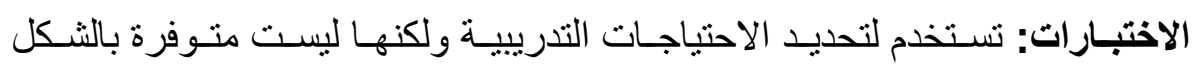
المناسب و المقنن، وتعطي مؤشرات عامة لا يمكن عدها نهائية في تقويم أداء الفرد.

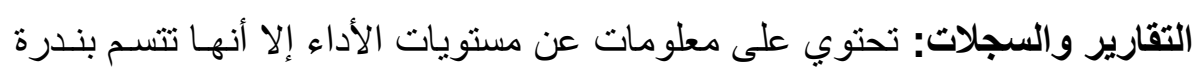
الموضو عية و لا يمكن الاعتماد عليها وحدها.

الملاحظة: يصلح هذا الأسلوب لرصد السلوكيات والمهار ات الاتصالية و التفاعلية.

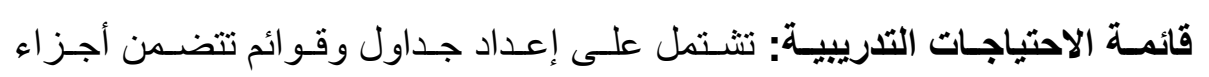

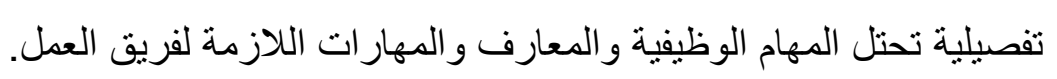

ب/ץ: تخطيط وتصميم التدريب ( تخطيط الإجراءات التدريبية):

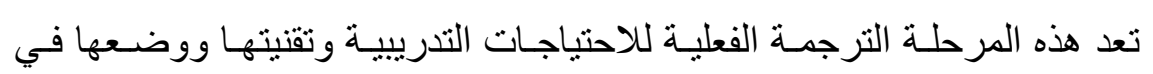
خطة مرسومة و اضحة الملامح، وتصميم هذه الخطة بنطوي على تحديد و اضـح ومحدد لفد لأهداف البرنامج ومحتو اه وموضو عاته و أساليبه وزمان ومكـان التدريب و وأسس اختيـار

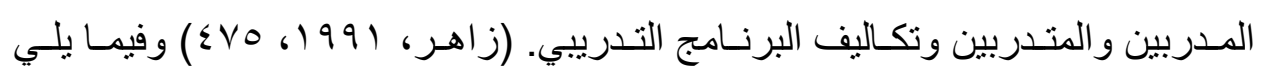
توضيح وتحليل لكل عنصر من هذه العناصر :

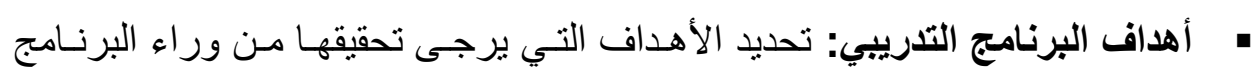

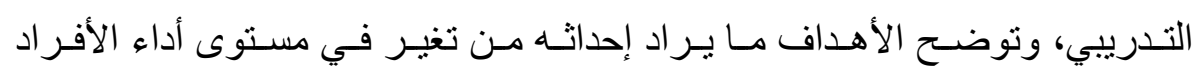

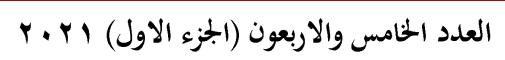

$(243)$
مجلة كلية التربية- جامعة عين شمس 
استخدام أسلوب بيرت PERT في تخطيط برنامج لتدريب فرق التخطيط الاستراتيجي في الجامعات المصرية فيطاية

و إتجاهاتهم وسلوكهم، و على ضو وئها يتم تحديد الجلسات و المادة التدريبية. (الثـر عة،

$$
\text { (Or G T } 1)
$$

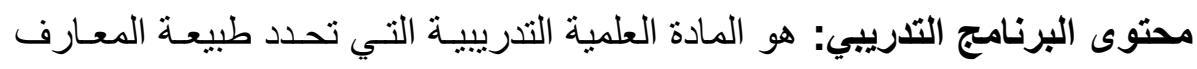

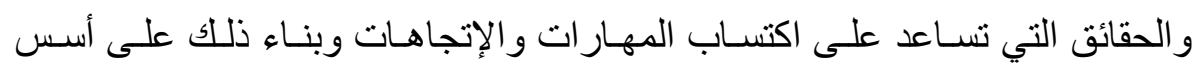
تربوية فلسفية، ويجب أن يتناسب المحتوى التدريبي مع طبيعـة المتدربين مـن حيث

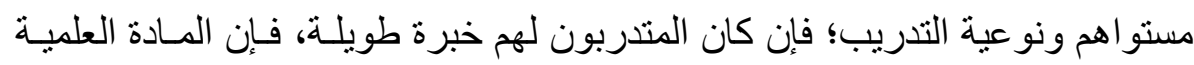
ستكون مختصرة، ويكون التركيز على التطبيقات والممارسات التربوية، أما إذا كـان المتدربون من ذوي الخبرات القليلة فإن المادة العلمية ستكون مكثفة. وسائل التدريب: هـي الوسيط الذي يستخدمه المدرب ليسـاعده في تحقيق أهداف

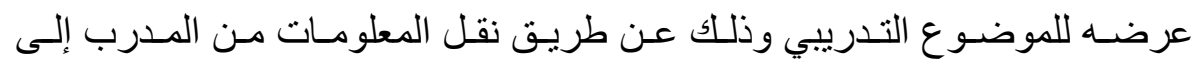
المتدرب، ويؤخذ في الاعتبـار عند اختيـار الوسيلة التدريبيـة القدرة والمهارة لدى المدرب على الاستخدام، ونوعية ومستوى وخبرة و عدد المتدربين، وأيضًا يؤخذ في

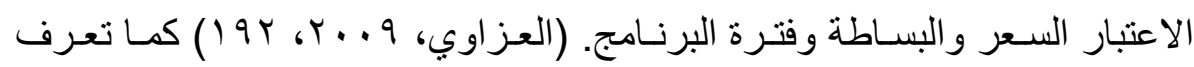

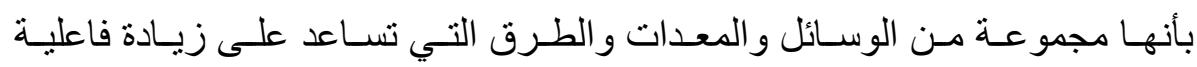
التـدريب، وتنقسـم إلـى الوسـائل البصـرية (الرسـوم التوضـيحية والبيانيـة، النمـاذج،

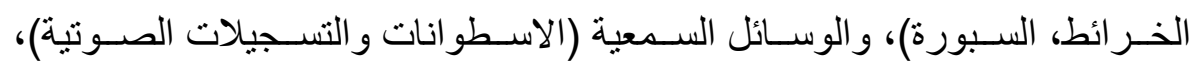

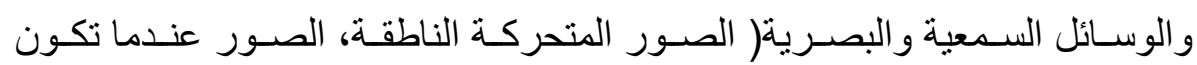

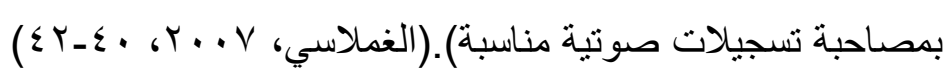
أسـاليب التـدريب: تتعد أسـاليب التدريب و لا يمكن استخدام هذه الأسـاليب بطريقة

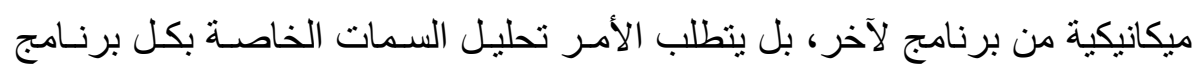

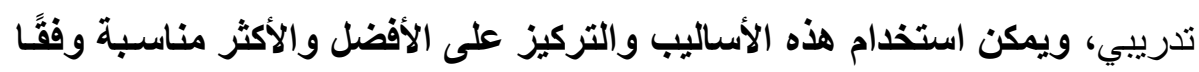
للعناصر التالية: 
هـدف التـدريب، إذ إن البرنـامج التـدريبي الـذي يهـدف إلـى زيــادة الخبـرات و المهار ات الفنية يتطلب أساليب مختلفة عن تللك التي تستخدم في البرنـامج الذي بهدف إلى تنمية وتطوير الإتجاهات البثرية في المؤسسات. المستوى الوظيفي، الأسـاليب التي تلائم تـدريب المديرين و المشـرفين و الأفراد

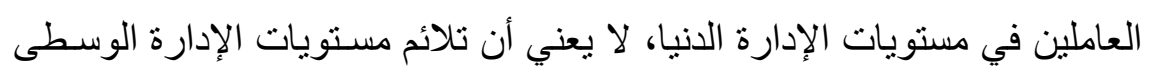
و العليا.

فترة التدريب، إذ تعد المحاضرة من أكثر الأسـاليب ملائمسة في البرنـامج قصسير

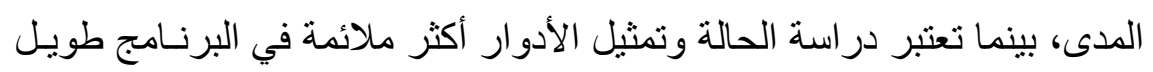
المدى.

المادة التدريبية، وتتمثل في كم وكيف المـادة التدريبيـة المطلوبـة لتحقيق أهداف

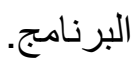
التكاليف وحجم المتـدبين، حيث تعد المحاضـرة هـي الأسـلوب الأفضـل عنــما ير اد تخفيض التكاليف و عندما يكون عدد المشاركين كبير. طبيعة العمل و الأساليب التي تستخدم في تدريب القـائعين بالأعمـال الإداريـة ومــا شـابه ذلك تختلف عن تلك التـي تسـتخدم في مجـال تـدريب الأفر اد القـائمين بالأعمال المهنية.

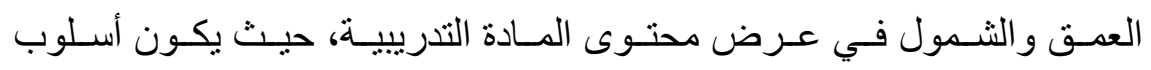

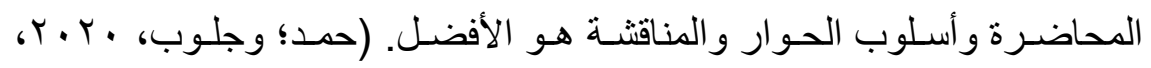
$\left(\varepsilon Y r_{-} \leqslant Y\right)$ مبادئ التعلم المتبعة، تشتمل على مبدأ الدافعية للتعلم و المشاركة الإيجابية من قبل المتدرب، مبدأ التقرد في التعلم، مبـدأ المتابعـة والتقويم والتغذيـة الراجعـة، مبـدأ

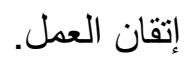
المتدرب، من حيث خلفيته العلمية والتقافية ومستوى ذكائه ودافعيته للتدريب. 
استخدام أسلوب بيرت PERT في تخطيط برنامج لتدريب فرق التخطيط الاستراتيجي في الجامعات المصرية

• المدرب، من حيث مؤ هلاته وخبر اته والقيم التي يتمتع بها وشخصيته. (علي،

$$
\text { (1) } 10.99
$$

" وتتر اوح أساليب التدريب ما بين أسـاليب نظريـة وأخرى عمليـة وثالثـة تعتمــ

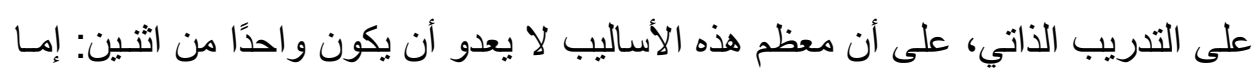

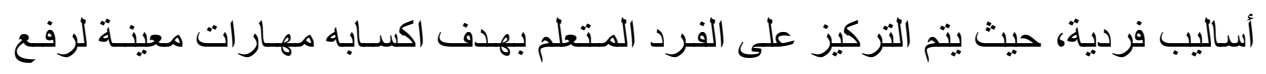

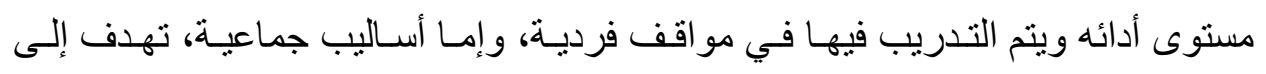

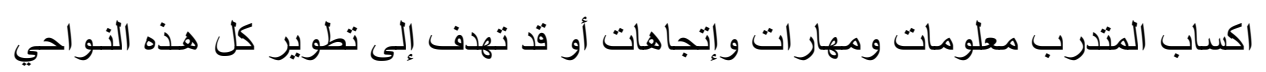

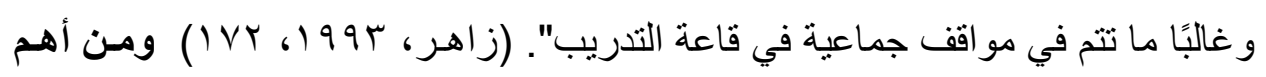

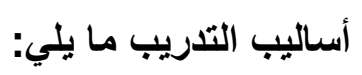
المحاضرة، تعد الأسلوب الأكثر استخداما في التدريب؛ فهي أسلوب لاكتسـاب عدد كبير من المتدربين كم كبير من المعلومـات والمعـارف ينقلها لهم المدرب، ولنجاح المحاضـرة يجب الإعداد الجيد لتنفيذها بمـا يحتـوى مقدمـة المحاضـرة ومضمونها وخاتمتها، ومن جانب آخر اختيار المدرب المناسب لتنفيذها. الحوار والمناقثنة، يتيح هذا الأسـلوب للمتدربين فرص أكبر للحـوار والمناقثـة

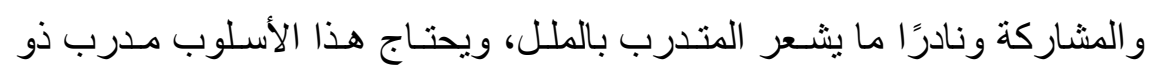

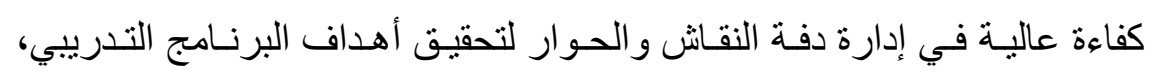
ويميل الكثير من المدربين لنطبيق هذا الأسلوب في التدريب في حال العمل على إلى اكتشـاف الملامسح الرئيسـة في مشكلات مـا واستخلاص نتـائج محددة بشـأنها.

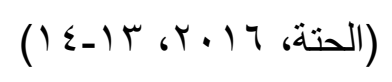

العصـف الـذهني، هـو أسـلوب توليـد أفكـار وآراء جديـدة مـن المتـدربين حـول موضوع ما. بحيث يتاح لكل متدرب جو من الحرية ووضع ذهنه في حالـة مـن فئ الإستثارة للتفكير في كل جو انب الموضوع للحصول منهم على أكبر قدر ممكن

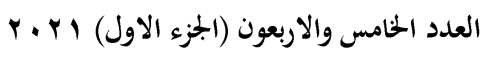

$$
\begin{aligned}
& \text { مجلة كلية التربية- جامعة عين شمس }
\end{aligned}
$$




\section{د/ وفـاء عبد القتــاح محمـود}

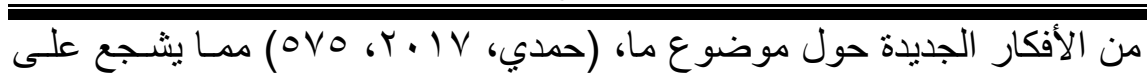

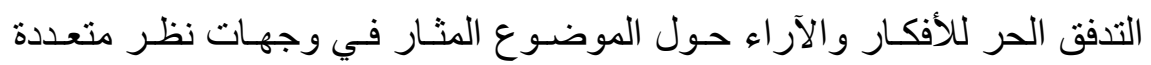
تناقش جميعها دون حكم في بداية التدريب. دراسة الحالة، هو أسلوب يتمثل في إعداد المدرب لحالة تصـف موقفًا أو مشكلة معينة في مجال نشـاط مؤسسـة مـا، وبعد تقديم الحالـة يبـدأ المـدرب في توجيـه المناقثـة لتعربـف المتـدربين على أسـباب المشـكلة. ويقسـم المـدرب مجموعـة المتدربين إلى مجمو عات صغيرة لتشـجيعهم على الحوار و التو اصسل و الوصـول إلى أكبر عدد مـن البـدائل للمشكلة المطروحـة، وتشــعهم على تتميـة قدر اتهم وتدعيم العلاقات الإنسانية. و هذا الأسلوب يكسب المتدرب مهار ات فكرية متعددة

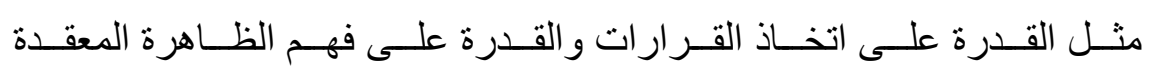

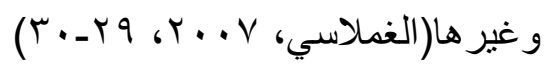

ورش العمل، أسلوب تدريبي جماعي تعاوني، توزع مـن خلالـه المهام التدريبيـة للوصول إلى حـل للمشكلات التدربييـة، وهـو نمـوذج للمناقثـة في المجمو عـات الصغيرة حيث يتم العمل بشكل تعـاوني لإنجـاز هدف معين وفت جدول للعمـل منظم يقوم بـه المشـاركون مع المدرب بحيث يسفر هذا العمل عـن إنتـاج تعليمسي مـا، و هـذا الأسـلوب ينمسي لـدى المتـدربين روح التعـاون و المحبـة و الألفـة بـين

$$
\text { الجماعة. (الغملاسي، V . . r. }
$$

أسلوب تمثيل الأدوار، عبارة عن عرض تمثيلية قصيرة لتشـيص مشكلة مـا أو موقف ما، و هو يجمـع بين المناقثــة والثـرح، ويعتمـد هذا الأسـلوب على قيـام المتدربين على تمثيل أدوار بعض الثخصـيات التي تقـابلهم في العمـل لمعالجـة مثكلة افتر اضية أو واقعية في مجال العلاقـات الإنسـانية أو المجـالات الأخرى، ويقوم المتدرب بأداء الدور كما ير اه هو . و الأداء النـاجح قصسير وسـريع الحركة

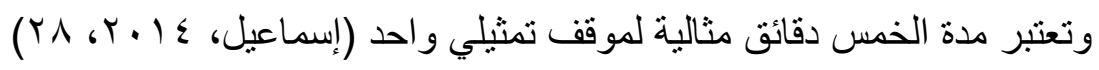




\section{استخدام أسلوب بيرت PERT في تخطيط برنامج لتدربب فرق التخطيط الاستراتيجي في الجامعات المصرية فيطاية}

هالتدريب عن بعد، يعتمد هذا الأسلوب على توظيف التكنولوجيا ووسائل الاتصـال الحديثة في تحقيق التواصل بين الأمـاكن وتجـاوز حدود الزمـان و المكـان، مثنل: الحاسب الآلي، الوسائط المتعددة التي تسهم في نقل الصـوت و الصـورة، إضـافة إلى توفر آليـات البحث المختلفة و المكتبـات الإلكترونيـة. و الفصـول الافتر اضـية التـي تقـوم على نمـوذج تشـبهي للفصـول التقليديـة، وتتيح الفرصـة للمتـدربين للحصول على التدريب في أي زمان ومكان. و التفاعل عبر الثـبكة والذي يعد مكملاً للفصول الافتراضية، إذ لابـد مـن وجـود تفاعل بين المتـدربين والمـدرب سواء من خلال الثبكة الاخلية أو الثبكة العالمية، ووجود مجموعة مـن الأدوات

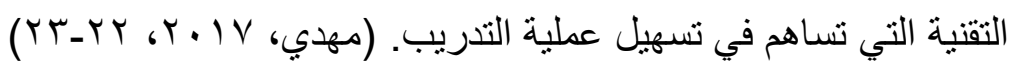
تحديد زمان التدريب ومكانـه: تحديد الفترة التـي يستغرقها التـدريب والتـي تختلف بـاختلاف أهداف البرنـامج ووحداتـه التدرييـة، وتثـــل مـدة البرنـامج ككل، و أيسام التدريب في كل أسبوع، وعدد سـاعات التدريب في اليوم الواحد. ثم تحديد مكسان التدريب داخل المؤسسة أم خارجها مع الأخذ في الاعتبار ملائمـة المكـان مـن حيث تو افر كافة الإمكانات و التسهيلات المادية اللازمة. اختيار المتدربين: من الضروري مراعاة التجانس النسبي بين مجموعـات المتدربين في البرنـامج التـدريبي الواحدــ ومـن المهم في خطـوة اختيـار المتدربين تهيئتهم للتندريب قبل بدء البرنامج التدريبي من خلال إرسال خطابات لهم تتضـمن مجموعـة

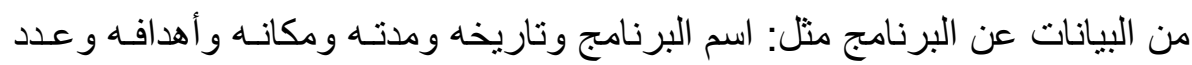

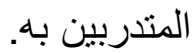

اختيار المدربين: لكي يتم تخطيط التدريب بشكل فعال، لابد أن يكون المدرب على

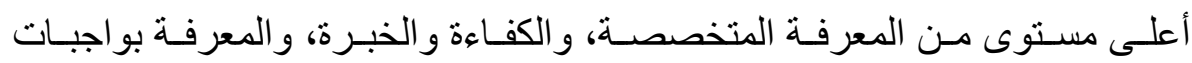




\section{د/ وفـاء عبد الفتــاح محمـود}

التدريب و المهارة الفنية في إدارة الجلسات التدريبية وطرق التدريب المختلفة، ولديـة

القدرة على الاتصال الجيد بالمتدربين.

تحديد تكاليف البرنامـج التدريبي: تقسم التكاليف اللازمـة للبرنـامج التـريبي لنو عين إحدهما نفقات استثمارية وأخرى تشغيلية. وتضم النفقات الاسـتثمارية كافـة مـا ينفق على المباني و التجهيز ات، في حين تضم النفقات التشغيلية: (أ) تكاليف مباثـرة وهي التي تتفق على الأنشطة المرتبطـة بشـكل مباثـر ببرنـامج معـين، (ب) تكـاليف غيـر مباشرة وهي التي تتفق في إعداد وتجهيز البـرامج التدريبيـة بصـفة عامـة ويصسعب

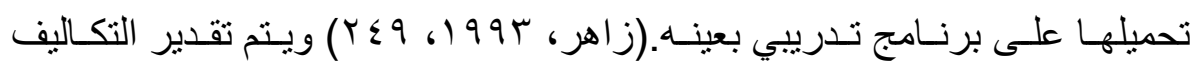
المباشرة التدريبية، والتـي تشـتمل: تكـاليف المطبوعـات والأدوات الكتابيـة، مكافـآت المشـرفين والمعـاونين، مكافـآت المـدربين، المكافـآت التشـجيعية للمتـدربين، بـدلات المتدربين، مساعدات التدريب، مستلزمات التدريب، تجهيز قاعات و أماكن التدريب، رســوم التــدريب الــداخلي، رســوم التـدريب الخــارجي، انتقــالات المتــدربين و المحاضـرين، العلاقـات العامـة، مصـروفات نثريـة، احتبـاطي عـام. (أبـو النصـر ،

$$
\text { (1) } 11 . .99
$$

ب/ ب: تنفيذ التدريب:

تتمثل هذه الخطوة في وضع البرنامج التدريبي موضع التنفيذ الفعلي، ويـتم ذلك

$$
\text { من خلال العمليات الإجرائية التالية: (سليمان، و99 (19 009) }
$$

وضـع خطـة لتنفيـذ البرنـامج، تكـون بمثنابـة توجيهـات لإدارة البرنـامج و المـدربين و المتدربين لكيفية التعامل مع عناصر البرنامج حيث يتضـح في هذه الخطـة طبيعـة كل هـدف مـع تحديـ المحتـوى التدريبي الخـاص بهذا الهـدف والأنشـة التدريبيـة المتعلقة بهذا المحتوى مع تحديد بدايـة ونهايـة كل نشـاط. حتى يضـمن المخطط أن النشاطات المقترحة لتحقيق الأهداف و اضحة وستتفذ فعليًا. 


\section{استخدام أسلوب بيرت PERT في تخطيط برنامج لتدريب فرق التخطيط الاستراتيجي في الجامعات المصرية فيطانية}

وضع برنامج عمل لتنفيذ هذه الخطة وتقسيم العمل وفقًا لـه على مر احل مـع تحديد

$$
\text { ب/ زء : متابعة وتقويم التدريب: }
$$

تعرف بأنها عملية مستمرة يقصد بها التأكد من أن خطة التدريب يتم تتفيذها بدقـة لتحقيق الهدف النهائي من التدريب، ومتابعة تنفيذ الخطة لإز الة أي معوقات قد تعترض ماض

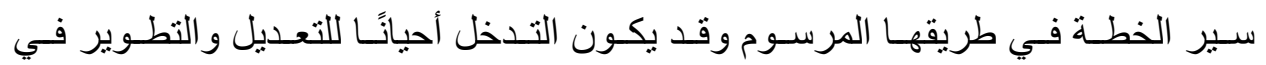
الإجر اءات التنفيذية للتدريب. أما تقويم التدريب لمعرفة مدى تحقيق البرنـامج التدريبي

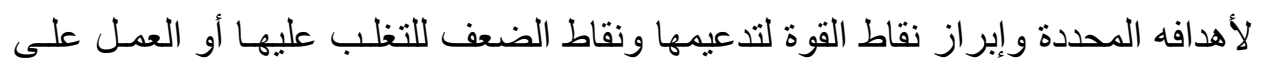
تلافيها في البر امج التالية حتى يمكن تطوير التدريب وزيـادة فاعليته بصـورة مستمرة.

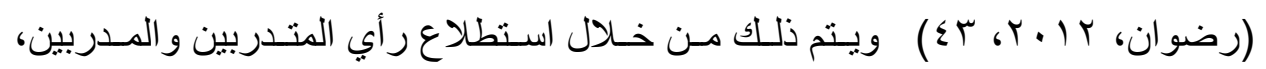
اختبار ات تعقد للمتدربين خلال وبعد انتهـاء البرنـامج التدريبي، تحليـل ومناقتــة حسالات وورش عمل البرنامج. تتم متابعة وتقويم المتدربين على ثناث مر احل، وهي:(الغملاسي، (ON-OV ، Y...V

تقييم المندربين قبل تتفيذ البرنامج التدريبي، تقييم المندربين قبل تتفيذ البرنـامج لتأكد من أن البرنامج سيقدم لهم ما يحتاجون إليه.

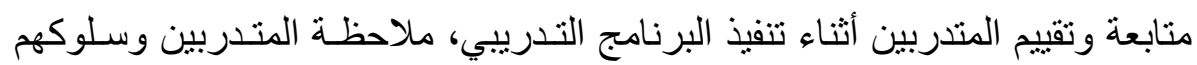

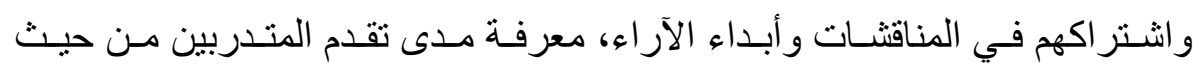
المعلومات و الخبرات المكتسبة من التدريب.

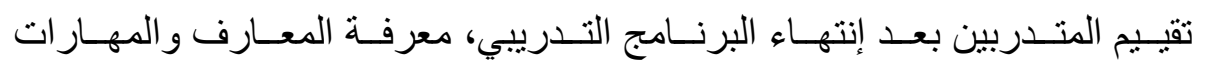

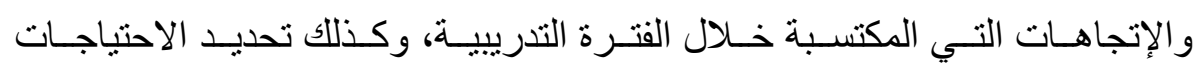
المستقبلية. 
"تعد مخرجات التدريب المنتج النهائي لبرنـامج التـدريب، وتتضـمن المخرجـات الإنسانية التي تتمثل في تتمية المعارف و المهار ات لدى المتدربين وقدر اتهم و إتجاهـاتهم،

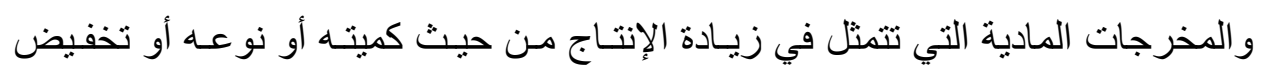

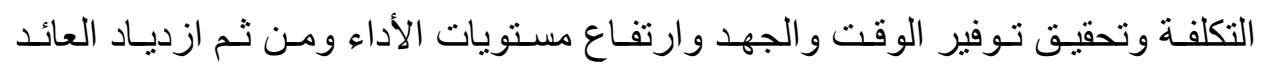
و المخرجات المعنوية وتتمثل في الجانب الفكري و النفسي للعاملين من حيـ الرضـا عن ونـ

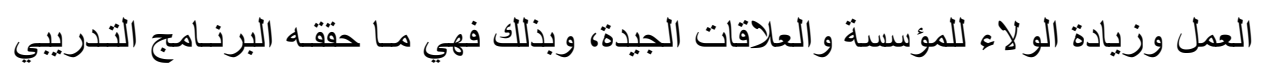

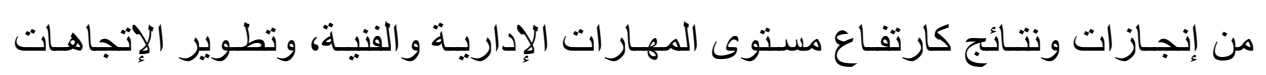

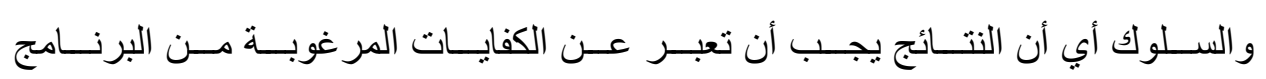

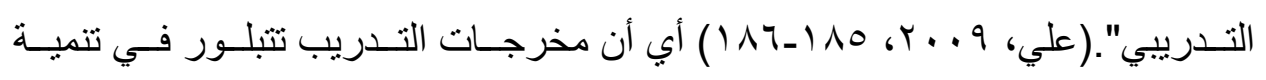
وتطوير الاحتياجات التدريبية والتي تظهر في شكل تحسين في مستويات الأداء، وتحقيق

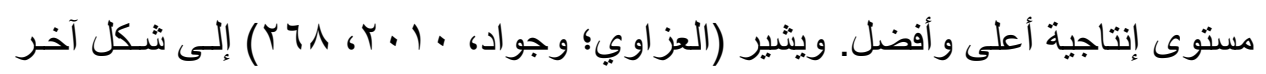

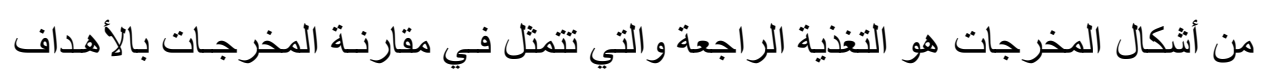

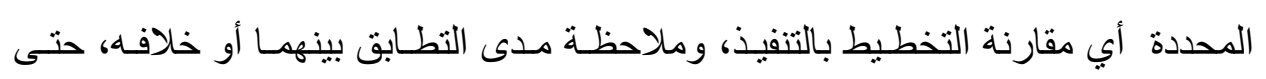

$$
\text { يمكن إجر اء التعديلات الضرورية. }
$$

ثالثًا: عوامل نجاح التدريب في تطوير الكفايات لدى فريق التخطيط الاستراتيجي: يوجد مجموعـة مـن العواملـ مـن الضـروري تو افرهـا حتـى يـتم تحقيق النجـاح

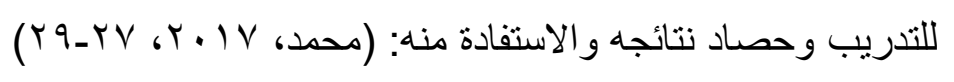

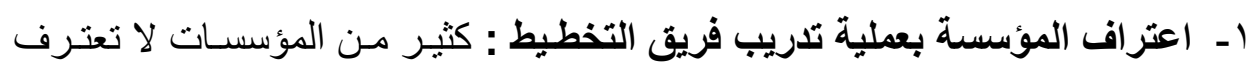

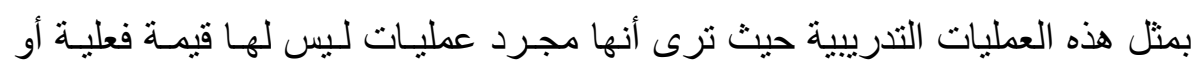

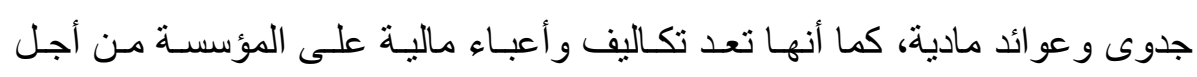
إجر اء أنواع التدريب اللازمة وتوفير كافة الأدوات المستخدمة أثناء التدريب، ولكن التهن

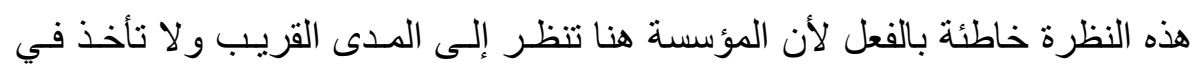

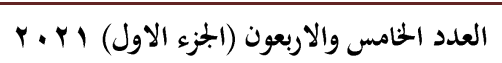


استخدام أسلوب بيرت PERT في تخطيط برنامج لتدريب فرق التخطيط الاستراتيجي في الجامعات المصرية

اعتبار ها أن الاقتصاد في تكاليف إعداد البر امج التدريبيـة لفريق التخطيط لا يعتبر توفير ولكن يعد أحد المسببات الرئيسة التي قد تعرض المؤسسة إلى تحمل الخسـائر

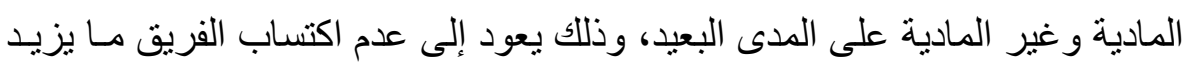
من كفاءتهم ويمنحهم المعارف و المهار ات المطلوبـة في إعداد الخطـة الاستر اتيجية الجيدة ومتابعة تنفيذها وتقويمها.

r- مدى صحة مضمون برنـامج عمليـة التـدريب: إن أحد العوامل التـي يتوقف عليهـا نجاح عمليات التدريب هو مدى صحة مضمون ومحتوى البرنـامج التدريبي بحيث يتم تدريب المتدربين على كفايات تعتبر من شأنهم أو مسئولياتهم.

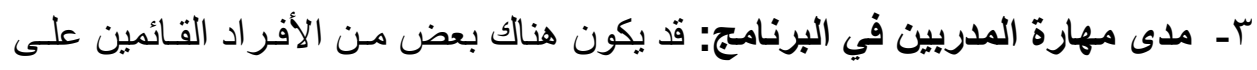
عملية التدريب لديهم الخبرة الكافية في ممارسات وطبيعة المهام ولكن هذا لا يعتبر كافي ولا يؤخذ بشكل منفرد حيث إن هنالك أيضًا عناصـر أخرى لهـا دور فعـال في

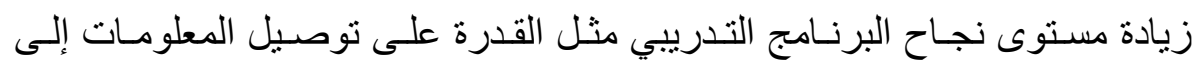
المتدربين بشكل سهل و على درجة كبيرة من الوضوح و هذه العوامل تتمثل في تو افر

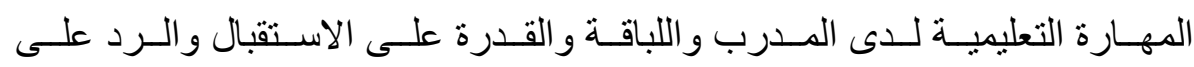
الاستفسار ات المتنوعة من قبل المتـدرب وتو افر الصبر للعمل الـائم على معالجـة الأخطاء التي تتعلق بعملية التدريب. ع - استعداد فريق التخطيط للخضوع إلى عملية التدريب: على الرغم مـن أن قد يكون

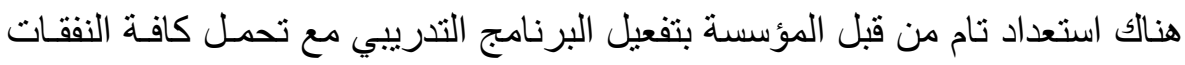

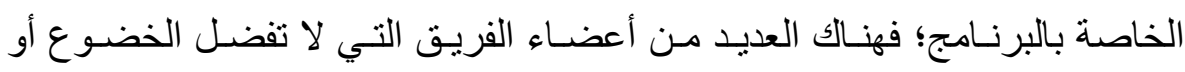

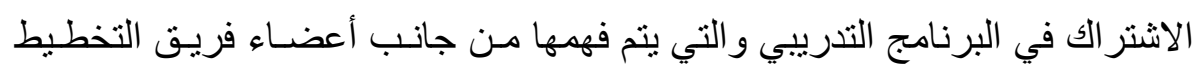

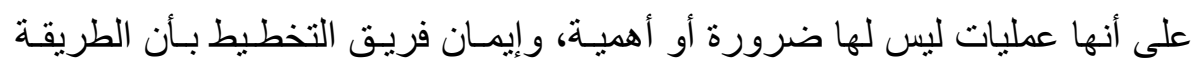

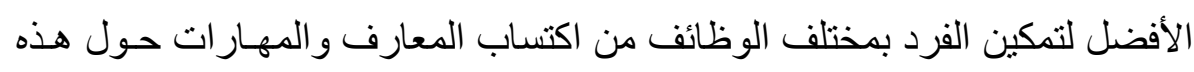




\section{د/ وفــاء عبد الفتــاح محمـود}

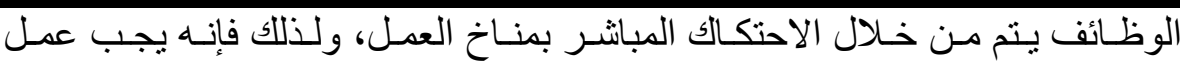
المؤسسة على مر اعاة أن يتم خضوع كافة أعضاء فريق التخطيط الاستر اتيجي التي لتي يستلزم تدريبها إلى البرنامج التدريبي دون قبول هاعل الأعذار. 0ـ ـــوافر المنـاخ المناسـب لإجراء عمليـة التـريب: قد تكـون كافـة العناصـر السـابقة اللازمة لنجاح عملية التدريب متوفرة بالفعل ولكن إذا كان هنالك أي قصور أو عجز في توفير البيئة المناسبة للتدريب قد ينتج عنه عدم تكامل العملية التدريبية. 7- تقدير الوقت اللازم لتنفيذ: إن عامل الوقت له تأنثير ودور فعـال في نجـاح عمليـات التدريب حيث إن تقدير الوقت الكافي و الذي يتناسب مع البرنامج التدريبي يمد عمليـة التدريب بالمساحة الزمنية الكافية للقدرة على إجر ء التدريب بشكل نـاجح دون تواجد

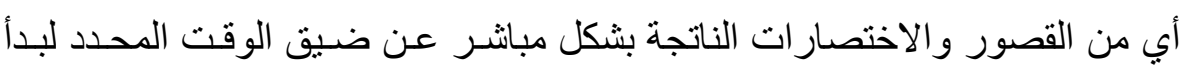

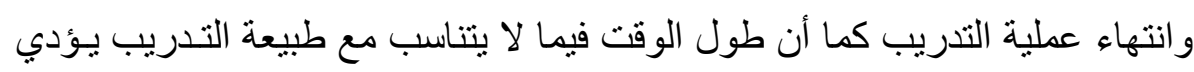
إلى شعور المتدرب بنوع من الملل وعدم القدرة على المو اظبة في حضـور البرنـامج التدربيجي.

V- الإمكانية المالية للمؤسسة لتغطية تكـاليف البرنـامج التدريبي: يعد تـوافر التناسب

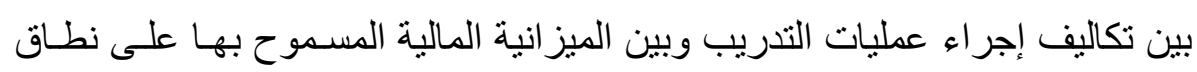
الإدارة المسئولة عن تنمية الموارد البشرية أمر هـام ويجب إجـراء الدارسـة الأوليـة

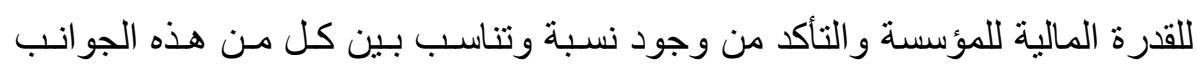
بحيث يجب ألا تتحمل المؤسسة تكاليف مادية تفوق قدارتها و إمكانياتها المالية. المحسور الثالـث: برنـامج تـدريبي لتطـوير الكفايـات التخطيطيـة لـدى فـرق التخطيط الاستراتيجي في الجامعات المصرية:(إطار تخطيطي مقترح) في ضوء رصد وتحليل أدوار ومسئوليات الفريق القائم بـالتخطبط الاستر اتيجي و التوصل من خلالها إلى قائمة الكفايات التخطيطية اللازمة لفرق التخطيط الاستر اتيجي بالجامعات للقيام بمسئولياتهم وأدوارهم، ومن خلال النظـر إلى التدريب باعتبـاره نظائًا 


\section{استخدام أسلوب بيرت PERT في تخطيط برنامج لتدربب فرق التخطيط الاستراتيجي في الجامعات المصرية فئة}

متكاملاً يتكون من مدخلات و عمليات ومخرجات، وترتبط المكونات فيما بينها بشبكة من العلاقات والارتباطات تتحدد مـن خلالهـا مجموعـة العناصـر التـي تحكم عمل البرنـامج التدريبي بدءً من تحديد الاحتياجـات التدرييـة ومن ثم تحديد أهداف البرنـامج ومحتو اه و أساليب ووسائل التدريب، عملية اختيار المتدربين والمـدربين، تحديد ميز انيـة البرنـامج و احتياجاته الزمنية، و إنتهاءً بوضع خطة لتنفيذ البرنـامج ومتابعته وتقويمـه، وفي ضـو

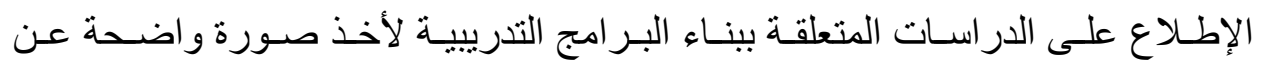
الخطوات الرئيسة في بناء وتصميم هذه البر امج مثنل دراسـة (السيد، بو 9 ())، ودر اسـة

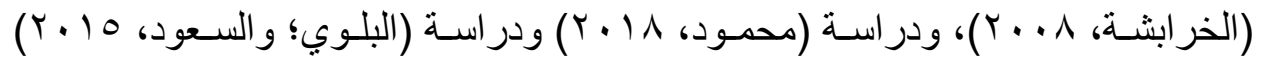

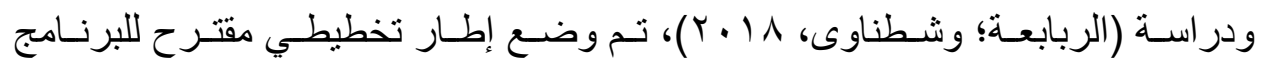
التدريبي على النحو التالي:

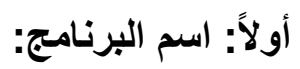
تطوير الكفايات التخطيطية اللازمة لفرق التخطيط الاستر اتيجي في الجامعـات

المصرية.

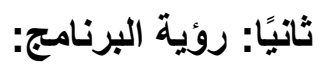

أن يصـبح الفريـق القـائم بـالتخطيط الاسـتر اتيجي قــادر علـى إعـداد الخطــة

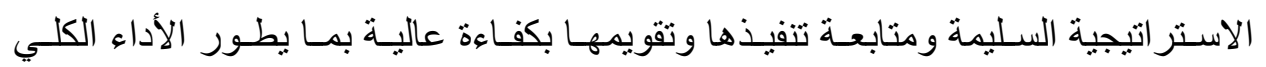
بالجامعة ويحسن الوضع التنافسي لها.

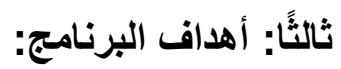

يهدف البرنـامج إلى اكسـاب الفريق القـائم بـالتخطبط الاسـتر اتيجي بالجامعـات المصرية مجموعـة مـن الكفايـات التخطيطيـة لإنجـاز مهماتـهـ ومسئولياته بكفـاءة عاليـة،

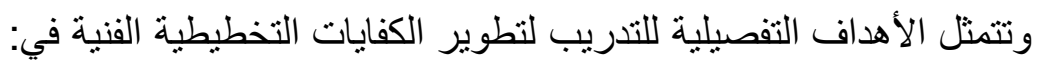




\section{د/ وفـاء عبد الفتــاح محمـود}

1 ـ امتلاك الفريق للكفايات المتعلقة بالتحليل البيأى للمؤسسة:

أـ الإلمام بمفهوم البيئة الداخلية والبيئة الخارجية للمؤسسة.

بـالقدرة على حصر عناصر البيئة الداخلية بالمؤسسة وتحليلها.

ج- القدرة على تحديد نقاط القوة و الضعف في البيئة الداخلية للمؤسسة.

د- القدرة على حصر عناصر البيئة الخارجية للمؤسسة وتحليلها .

ه- القدرة على تحديد الفرص والتحديات في البيئة الخارجية للمؤسسة.

و- القدرة على إجادة استخدام الأساليب العلمية في التحليل البيئى للمؤسسة.

ز - القـدرة علـى إجـادة اســخدام الأسـاليب العلمبـة لجمـع البيانـات و المعلومـات

المطلوبة.

ح- الاعتماد على نتائج الدراسات و البحـوث السـابقة حـول المؤسسـة لجمـع البيانـات و المعلو مات.

ط- المشاركة ضمن فريق عمل أثناء تحليل البيئة الداخلية و الخارجية للمؤسسة. ي- القدرة على عمل مصفوفة التحليل الرباعي للمواقف الاستراتيجية. r- امتلاك الفريق للكفايات المتعلقة بصياغة رسالة وروئية المؤسسة: أ- الإلمام بمفهوم رسالة المؤسسة ورؤيتها. بـالقدرة على صباغة رسالة ورؤية المؤسسة بدقة ووضوح. ج- القدرة على وضع رسالة تتسم بالو اقعية والثبات النسبي. د- التركيز على متطلبات المجتمع من المؤسسة في صياغة الرسالة. هـ مهارة صياغة رؤية طموحة ومحفزة وتعبر عن قيم وفلسفة المجتمع. و - صـياغة رؤيسة تسـتمد أصسولها مسن ماضـى المؤسسـة وحاضـر ها و احتياجاتهـا المستقبلية.

ز - صياغة رؤية قابلة للتحول إلى سياسـات وخطط وبـر امج ومشـرو عات وأنشـة قابلة للتنفيذ. 
استخدام أسلوب بيرت PERT في تخطيط برنامج لتدريب فرق التخطيط الاستراتيجي في الجامعات المصرية فيطاية

ح- مر اعاة القو انين و التشـريعات و القرارات و اللـوائح التنفيذيـة للمؤسسـة في بنـاء

$$
\text { الرؤية والرسالة. }
$$

ط- مهارة الإبتكار و الإبداع و التفكير التأملي في صياغة رسالة ورؤية المؤسسة.

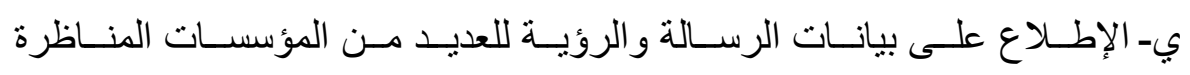

$$
\text { و الاسترشاد بها. }
$$

ك- القدرة على ربط رؤية المؤسسة برسالتها الاستر اتيجية. ل- مشاركة المعنيين من داخل وخارج المؤسسة في تصور رسالة ورؤية المؤسسة. م- تحفيز العاملين على ضرورة تبني رسالة المؤسسة ورؤيتها.

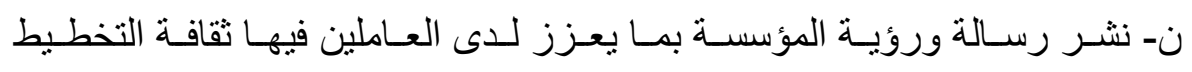
الاستر اتيجي.

r- امتلاك الفريق للكفايات المتعلقة بالغايات والأهداف الاستراتيجية:

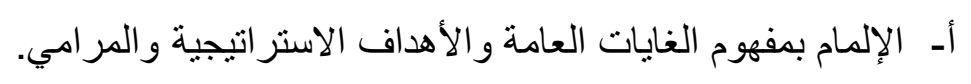

بـ القدرة على تحديد غايات تتسم بالعمومية والثمول لمجالات عمل المؤسسة.

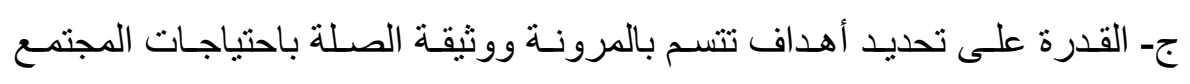
الحالية و المستقبلية.

د- صياغة أهداف و اضحة ومرنة وقابلة للقياس وفق رسالة المؤسسة ورؤيتها. ه- صياغة أهداف محددة بمدى زمني معين وفق رسالة المؤسسة ورؤيتها. و - تحديد أهداف و اقعية مشتقه من فلسفة المجتمع وقيمه وثقافته. ز - مر اجعة الأهداف بطريقة منتظمة في ضوء التحليل البيئى للمؤسسة.

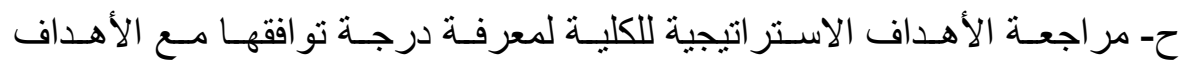
الاستر اتيجية للجامعة. 


\section{د/ وفـاء عبد الفتــاح محمـود}

\section{ء- امتلاك الفريق للكفايات المتعلقة بصياغة الخطة الاستراتيجية:}

أـ الإلمام بمفهوم صياغة الخطة الاستر اتيجية.

ب-تحليل الفجوة بين الوضع الراهن للمؤسسة ومستقبلها المرغوب.

ج- تحديد المواقف و البدائل الاستر اتيجية المحتملة للمؤسسة.

د- المفاضلة بين البدائل الاستر اتيجية المحتملة للمؤسسة.

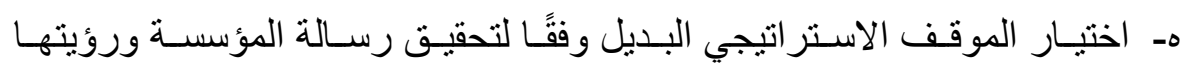

$$
\text { و أهدافها. }
$$

و - معرفة محاور و عناصر وثثية الخطة الاستر اتيجية للمؤسسة. ز - صياغة خطة للكلية تتسجم وتتو افق مع خطة الجامعـة ومـع خطسة وزارة التعليم العالي ومع الفلسفة العامة للمجتمع المصري. ح- إيصال الخطة إلى العاملين بالمؤسسة و أصحاب المصالح. ط- الإلمام بالاستر اتيجيات الطارئة.

ي- القدرة على وضع خطة للطو ارئ لمواجهة الأزمات المحتملة. هـ امتلاك الفريق للكفايات المتعلقة بصياغة الخطة التنفيذية:

أـ القدرة على ترجمة الأهداف الاستر اتيجية إلى الأهداف التنفيذية. ب-مهارة صياغة الأهداف التنفيذية بمرونة وو اقعية وفي حدود الموارد المتاحة. ج- القدرة على تحديد الأنشطة التي تحقق كل هدف من الأهداف التنفيذية. د- إعداد مؤشرات الأداء التي تغطى الأهداف بالكامل. هـ - تحديد القترة الزمنية لتنفيذ المؤشرات الأداء.

و - تحديد مساهمة الأجهزة و الأقسام المختلفة في تحقيق المؤشرات.. ز - تحديد المهام و الواجبات لكل وحدة تنظيمية بالمؤسسة. ح-وضع الموازنات المالية لكل مكون من مكونات الخطة لتنفيذ الأهداف في الوقت وهن المناسب.

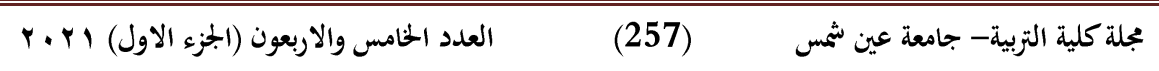


استخدام أسلوب بيرت PERT في تخطيط برنامج لتريب فرق التخطيط الاستراتيجي في الجامعات المصرية

ط- مشاركة العاملين في وضع البرامج التنفيذية ومؤشرات الأداء اللازمة لتحقيق الأهداف.

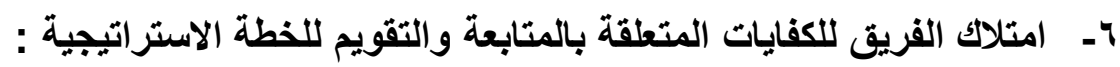

$$
\text { بـ أل الإلمام بطرق متابعة وتقييم الأداء. }
$$

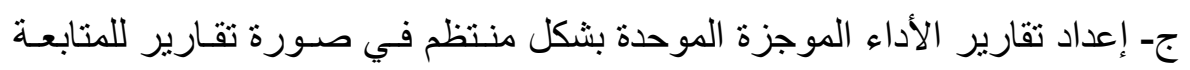
و التقويم.

د- كتابة تقارير دورية عن عملية المتابعة والتقويم لعملية تتفيذ الخطة. هـ - تحليل المعوقات التي تحول دون تحقيق أهداف الخطة، و الحد من تأثير ها.

$$
\text { و - تفسبر نتائج التقويم في ضوء الأهداف الموضو عة. }
$$

ز - تحديد مؤشرات لمتابعة أداء تنفيذ الخطة وتقويم مدى تحقيق أهدافها.

ح- تحديد آليات و اضحة للمتابعة والتقويم عند تنفيذ الخطة الاستر اتيجية.

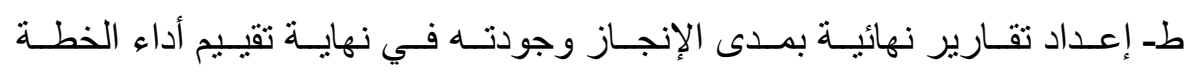
الاستر اتيجية

ي- مقارنة النتائج المحققة فعلاً بأهداف الخطة الاستر اتيجية. ك- تزود كل الجهات المنفذة بالتغذية الراجعة لعملية تنفيذ الخطة. ل- مشاركة المعنيين في الخطة في عملية المتابعة و التقويم. م- القدرة على تعديل الخطة في ضوء التغذية الراجعة. ن- عمل التقييم النهائي الختامي للخطة الاستر اتيجية في ضوء الغايات والأهداف. س- تحديد مواطن الضعف التي يجب مر اعاتها عند الثروع في وضع خطة جديدة. ع- القدرة على وضع خطة نطويرية بناء على نتائج التقويم السابقة. 
تقترح الباحثـة أن يعقد البرنـامج على مسـتوى الجامعـة الأم التـي ينتمسي إليهـا

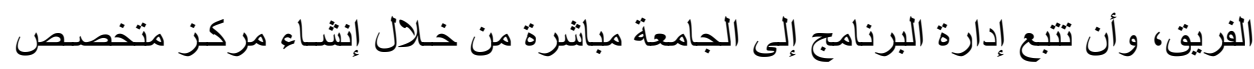

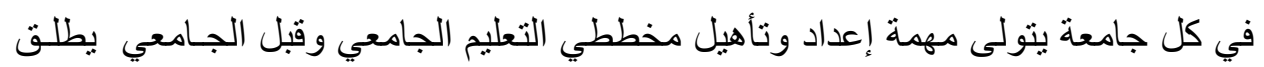

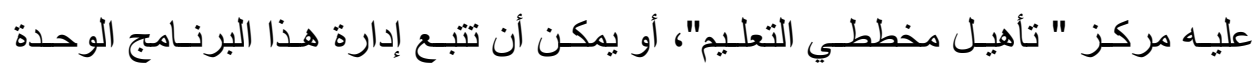

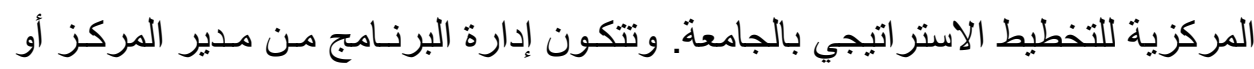

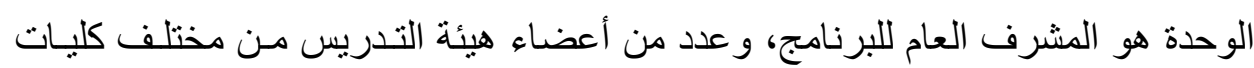
الجامعة، و إثنان مسئول إدارى، مع ضرورة نو افر الخبرة في من يتولى إدارة البرنـامج ،

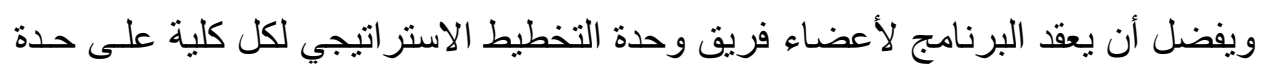
بحيـث يكـون التخصـص واضـح لمـدرب الـدورة، ويكـون المـدرب قريـب مـن مجــال التخصص الأكاديمي للفريق. خامسًا: مكان عقد البرنامج ومدته: يعقد البرنـامج في قاعـة تـدريب مناسبة مـن حيث التهويـة والإضـاءة و الموقـع وتوزيع الأثاث، ويفضل أن تتسع لعدد O شخص على الأقل مسع مسـاحة حرة لتطبيق

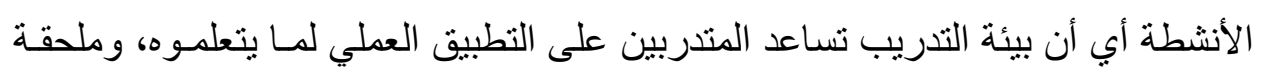

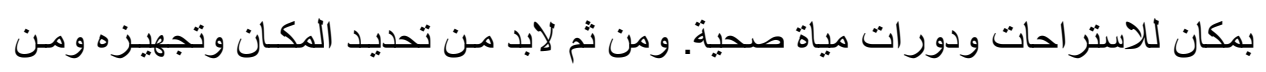

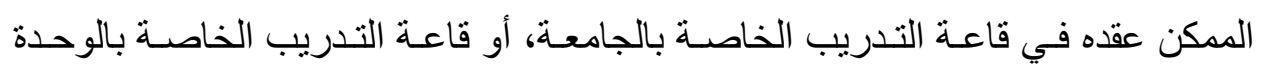
المركزية للتخطيط الاستر اتيجي بالجامعـة إن وجد. ويستغرق تقديم( الدورة التدريبيـة) المحتوى التدريبي للبرنامج حو الي شهر واحد دراسة مكثفة، ويقتر ح أن يكون عدد أيسام تنفيذ موضوعات المحتوى التدريبي 17 يوم عمل موزعة على أربع أسابيع بواقع أربـع

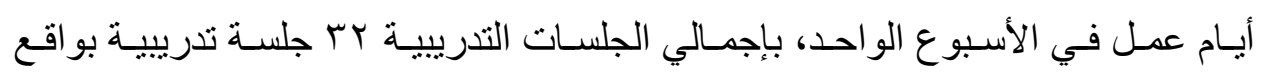

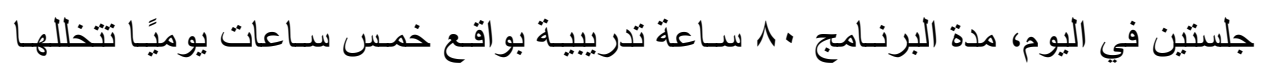
إستر احة لمدة نصف ساعة.

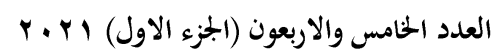

(259)
مجلة كلية التربية- جامعة عين شمس 
استخام أسلوب بيرت PERT في تخطيط برنامج لتتريب فرق التخطيط الاستراتيجي في

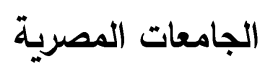

سادسًا: المحتوى التدريبي للبرنامج:

تحقيقاً لأهداف البرنامج نم اختيار المحتوي التندريبي، وقد روعي في اختياره

الثمولية لكافة الموضو عات التي ترفع من درجة امتلاك المندربون للكفايات التخطيطية.

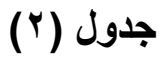

محتوى الاورة التدريبية:( مجالات تطوير الكفايات التخطيطة)

\begin{tabular}{|c|c|c|c|c|c|c|c|}
\hline \multicolumn{3}{|c|}{ الزمن بالساعات } & \multirow{2}{*}{ محتوى الوحدة } & \multirow{2}{*}{ التروضيبي } & \multirow{2}{*}{ الالوحيةة } & \multirow[t]{2}{*}{ اليوم } & \multirow[t]{2}{*}{ الأسبوع } \\
\hline \multirow{21}{*}{ إl } & علي & نظرى | ن إن & & & & & \\
\hline & \multirow[t]{20}{*}{$\varepsilon$} & \multirow[t]{20}{*}{1} & مقدمة مقة مقدم & \multirow{21}{*}{ الاستراتيجيط } & \multirow{21}{*}{ الأولى } & الأول & \multirow{21}{*}{ الأأسبوع } \\
\hline & & & - ـ تطور ــ الفكر & & & الثاني & \\
\hline & & & ـ مفاهخيط التخطي. & & & & \\
\hline & & & - ماهية التخطط & & & & \\
\hline & & & الاستَّر اتيجي. & & & & \\
\hline & & & - التفكير & & & & \\
\hline & & & الاستراتيجي. & & & & \\
\hline & & & - مفهوم - مفي & & & & \\
\hline & & & _ـ التخطرط & & & & \\
\hline & & & الاستر اتتجيجي(الذف & & & & \\
\hline & & & هوم & & & & \\
\hline & & & و والخصائص). & & & & \\
\hline & & & - & & & & \\
\hline & & & و الأتخطريط: التجي & & & & \\
\hline & & & التقليدي. & & & & \\
\hline & & & - & & & & \\
\hline & & & الاستراتيجي & & & & \\
\hline & & & التخطسويط & & & & \\
\hline & & & الأخرى. & & & & \\
\hline & & & - أهمية التخطيط & & & & \\
\hline & & & الاستر & & & & \\
\hline
\end{tabular}

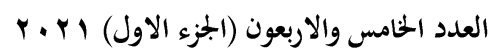

مجلة كلية التربية- جامعة عين شثس (260) 
د/ وفـاء عبد القتــاح محمـود

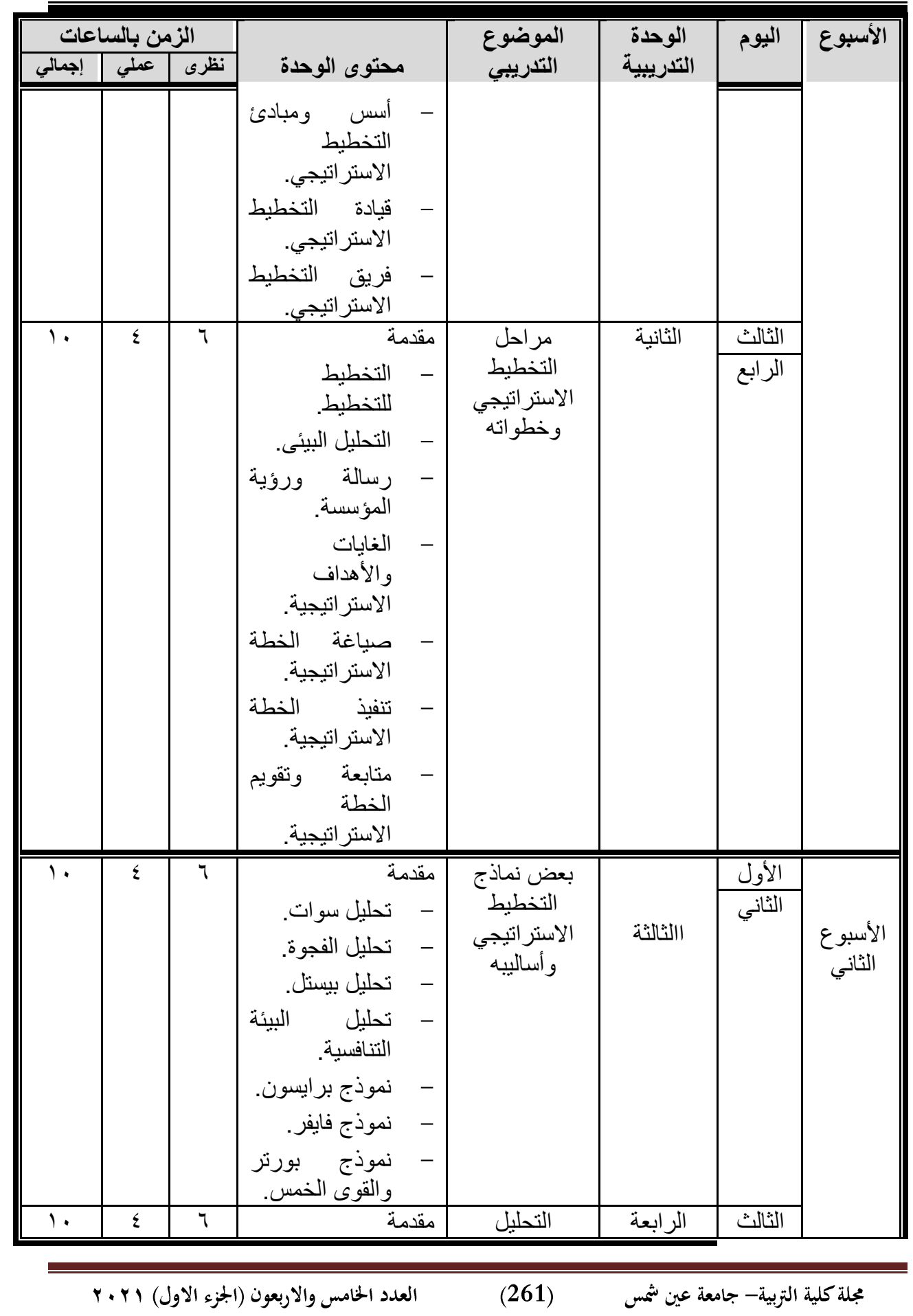


استخدام أسلوب بيرت PERT في تخطيط برنامج لتربب فرق التخطيط الاستراتيجي في الجامعات المصرية

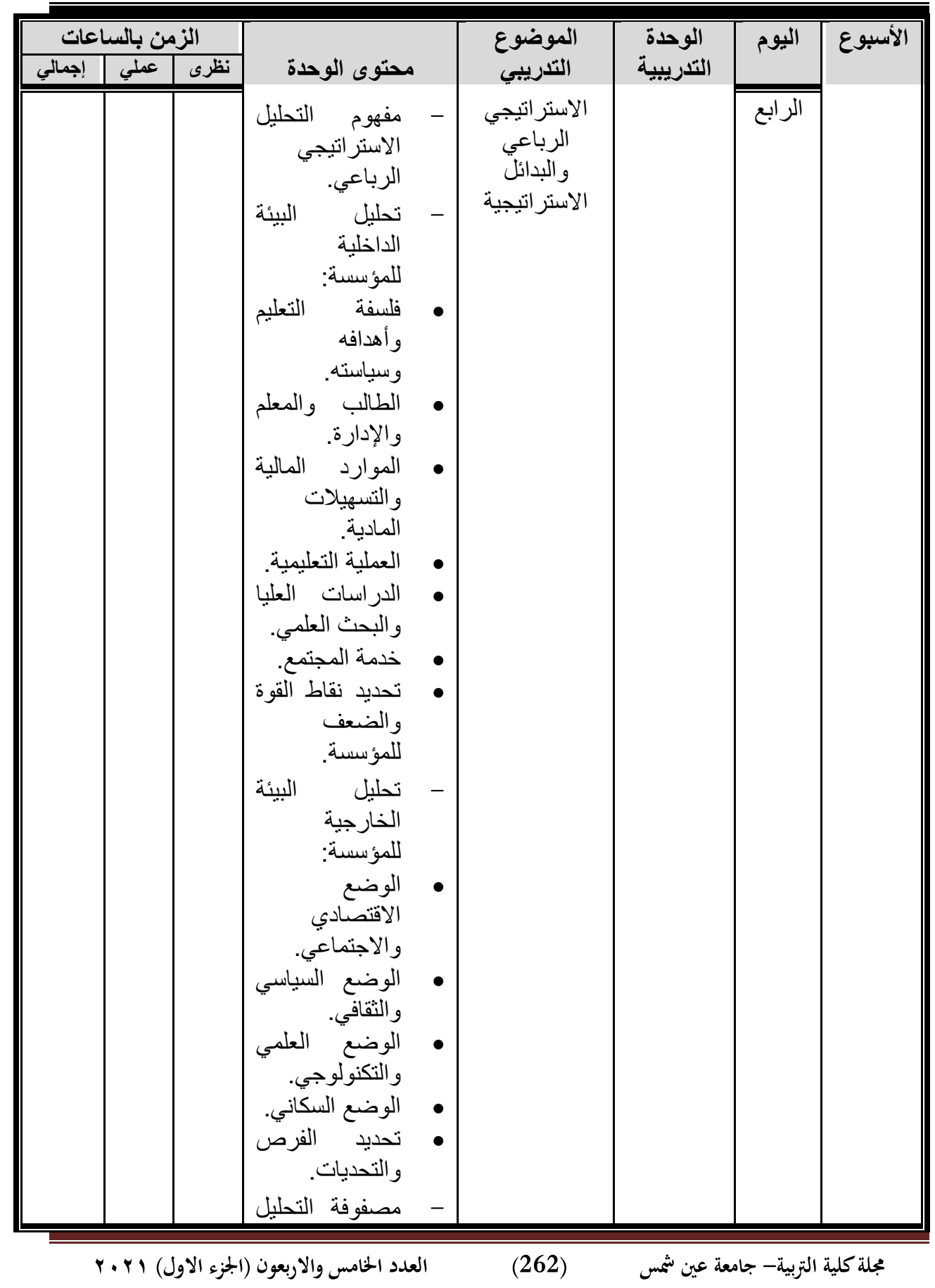


د/ وفـاء عبد الفتــاح محمـود

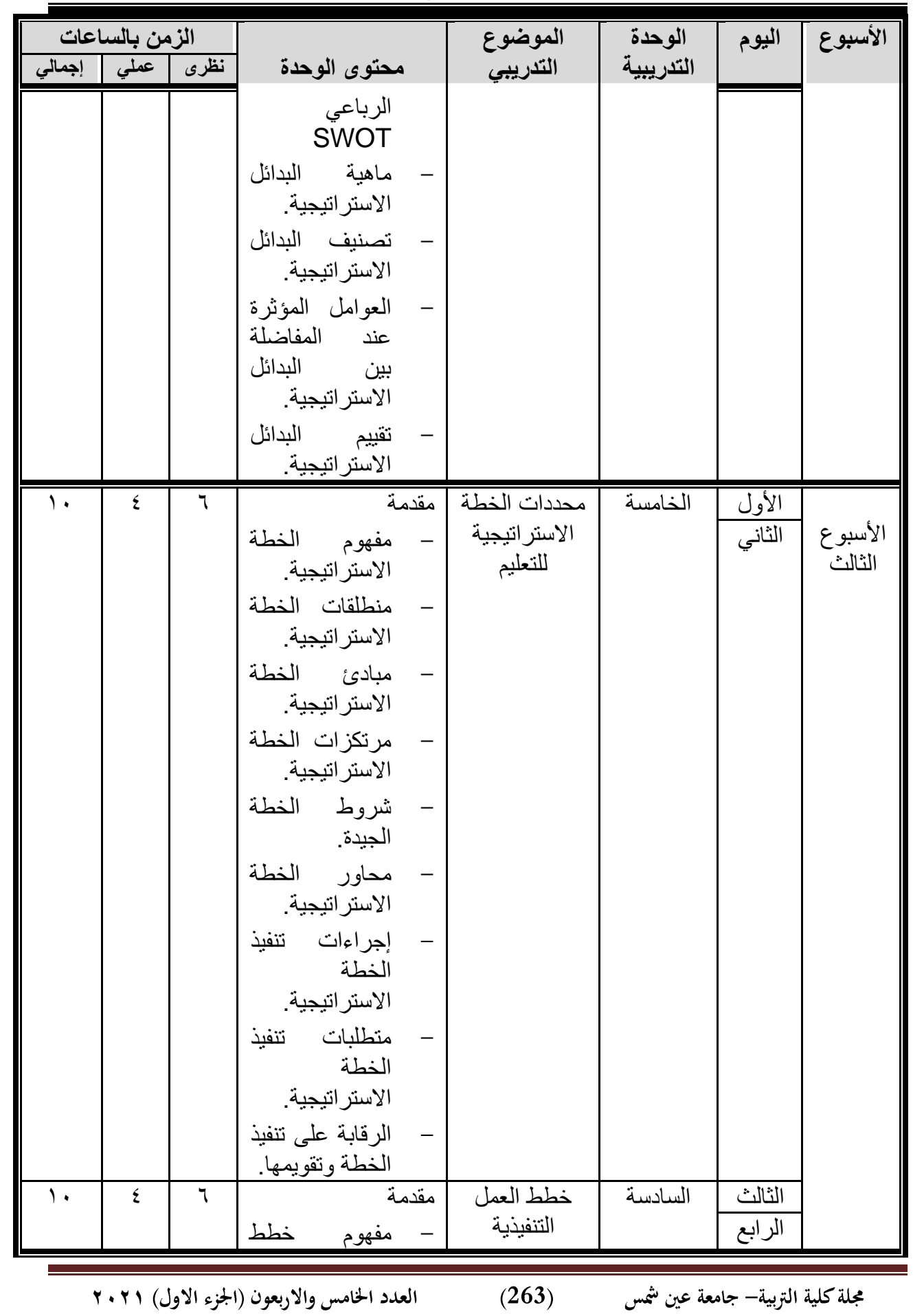


استخدام أسلوب بيرت PERT في تخطيط برنامج لتريب فرق التخطيط الاستراتيجي في المصرية

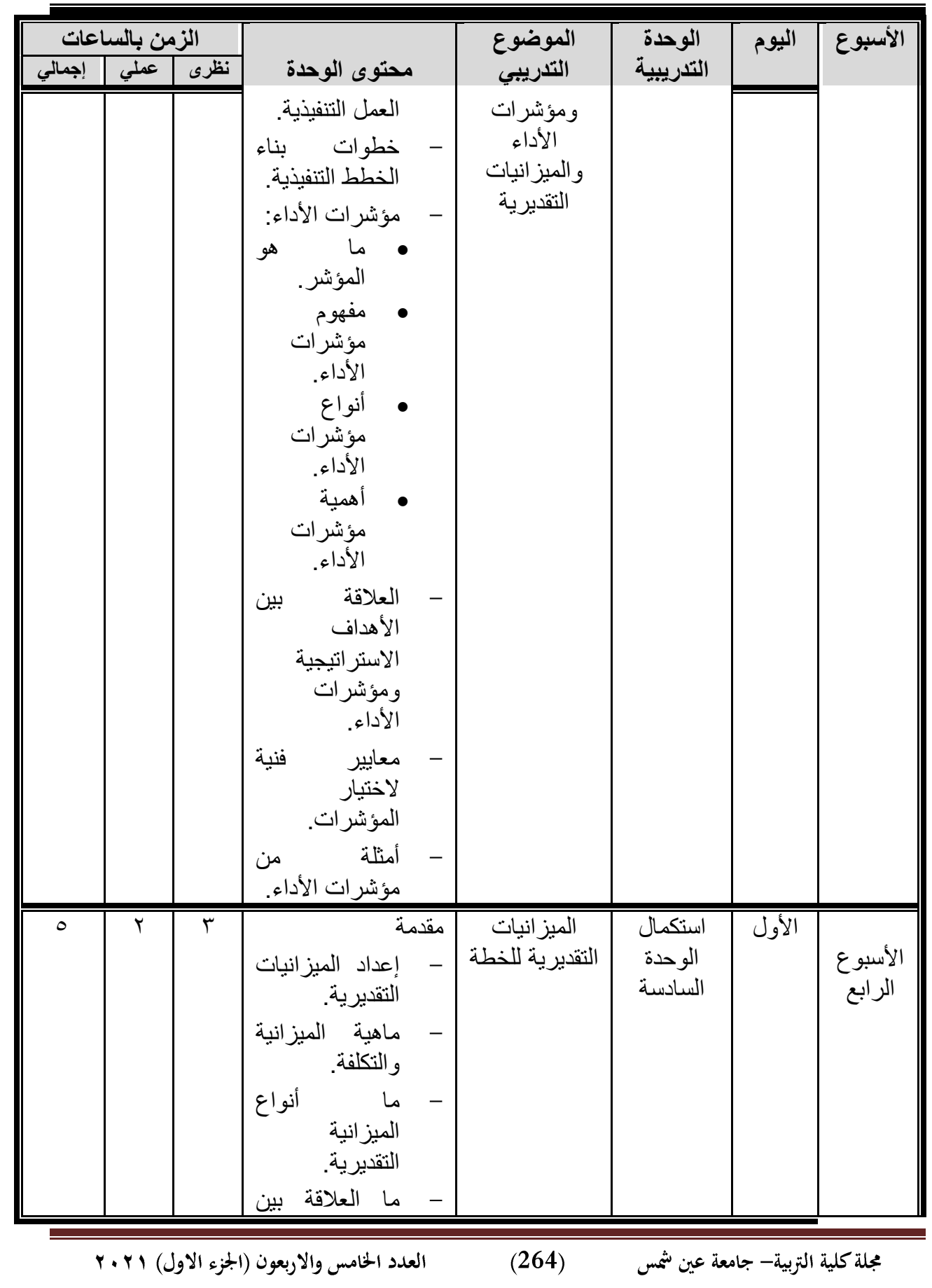


د/ وفـاء عبد الفتــاح محمـود

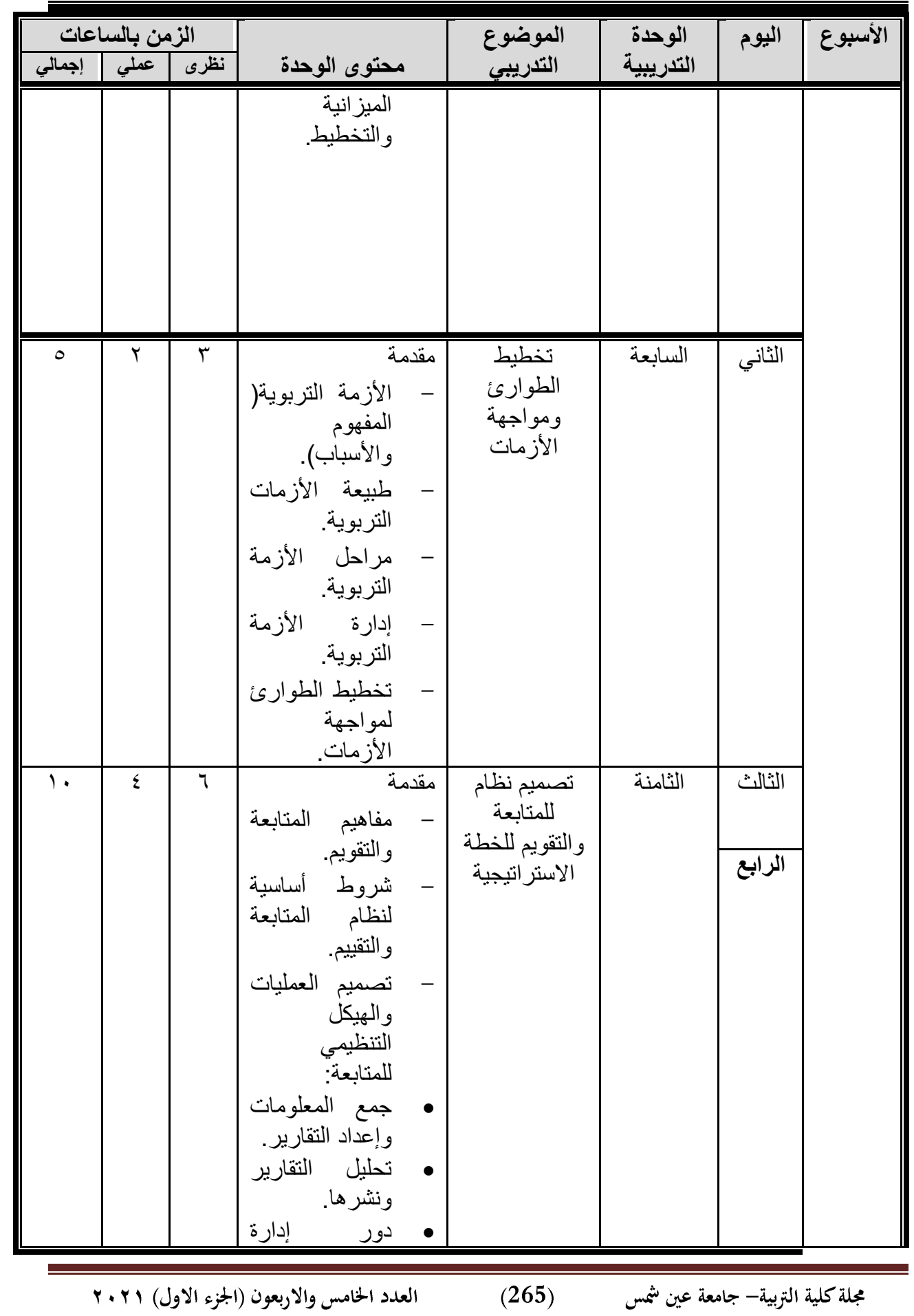


استخدام أسلوب بيرت PERT في تخطيط برنامج لتدربب فرق التخطيط الاستراتيجي في الجامعات المصرية

\begin{tabular}{|c|c|c|c|c|c|c|c|}
\hline \multicolumn{3}{|c|}{ الزمن بالساعات } & \multirow[b]{2}{*}{ محتوى الوحدة } & \multirow{2}{*}{ التدرضيوع التوضي } & \multirow{2}{*}{ التدريبية } & \multirow[t]{2}{*}{ اليوم } & \multirow[t]{2}{*}{ الأسبوع } \\
\hline إجمالي & عملي & نظرى & & & & & \\
\hline & & & التشاريط. & & & & \\
\hline
\end{tabular}

تم إعداد الجدول السابق استنادًا على مسح العديد من الأدبيات و الدر اسات السـابقة التي تناولت التخطيط الاستر اتيجي، وتنظيم موضوعات الوحدات التدريبيـة وفقاً لتسلسل منطقي في ضوء منهجية التخطيط الاستر اتيجي. سابعًا: القائمون بالتدريب في البرنامج: ا - أساتذة الجامعة ذوى الخبرة في مجال التخطبط الاستر اتيجي.

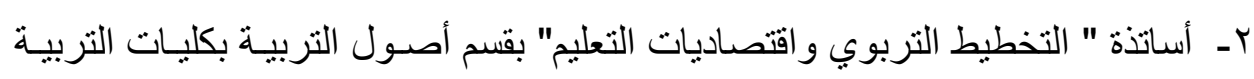
المصرية. rــ أسـاتذة الجامعـة الحاصلين على دبلـوم التخطبط الاسـتر اتيجي مـن معهد التخطبط القومي. ع ـ أسـاتذة الجامعــة الحاصـلين على دورة التخطـيط الاسـتر اتيجي مـن الهيئسة القوميـة لضمان الجودة التعليم والاعتماد. 0- خبر اء مدربون من معهد التخطيط القومي بالقاهرة.

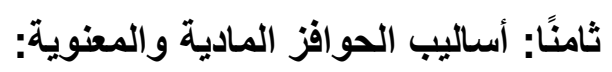
1 - التفرغ التام أثناء الالتحاق بالبرنامج التدريبي منح شهادة لمن يجتاز الدورة بنجاح. r- إنح مكافأة مالية لمن يجتاز الدورة بامتياز.

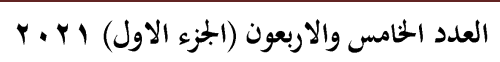
(266) مجلة كلية التربية- جامعة عين شمس 
د/ وفـاء عبد الفتــاح محمـود

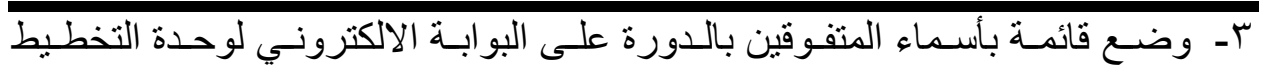

$$
\text { الاستر اتيجي بالكلية و الجامعة. }
$$

تاسعًا: أسسالبب التدريب:

المحاضرة، النقاش الموجـه، النقـاش والحـوار ، العصـف الـذهني، تمثيـل الأدوار، ورش العمل، التعلم التعاوني. عاشرًا: المواد التدريبية:

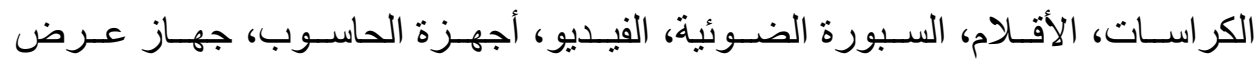
بروجكتر ، ورق عـريض لعمـل المجموعـات، كر اسـات التـدريبات المتضــنة لأوراق العمل. الحادي عثر: تقدير موازنة التدريب:

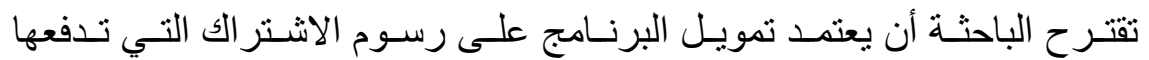

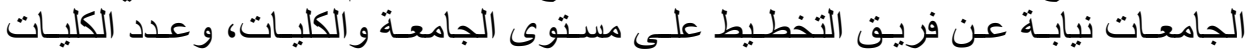

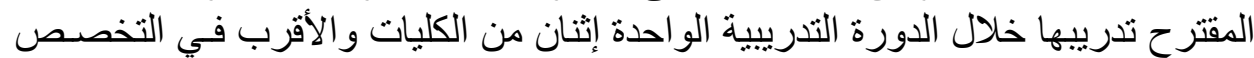

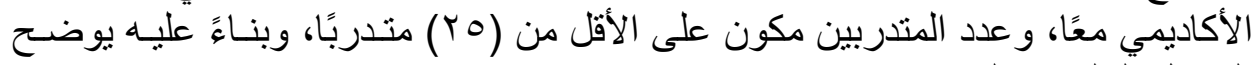

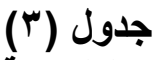

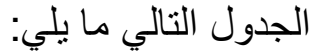

التكاليف المباشرة التقديرية للاورة التدرية

\begin{tabular}{|c|c|c|c|c|c|}
\hline التكلفة الإجمالية للبرنامج (بالجنية) & اللوحدةة التقليرية) & العدد & الوحدة & البيان & p \\
\hline $97 \ldots=17 \times 1 \times 7 \ldots$ & $7 \ldots$ & 1 & يوم تدريبي & أجور المدربين & 1 \\
\hline$r_{Y} \ldots=17 X Y X 1 \cdots$ & $1 \cdots$ & r & يوم تدريبي & اجور الإداريين & T \\
\hline 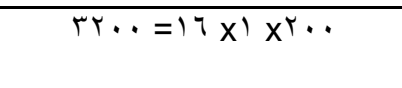 & r.. & 1 & يوم تدريبي & مكآفاة فريق & 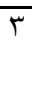 \\
\hline NYr. $=17 X Y T X Y$. & $r$. & $r T$ & يوم تدريبي & نفقات المو اد & $\varepsilon$ \\
\hline $1 T^{1} q r \cdot=17 X^{q} X^{r}$. & $r$. & rq & يومية & نفقات الضيافة & 0 \\
\hline 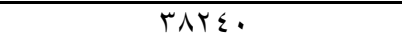 & - & - & - & الإجمالي & \\
\hline
\end{tabular}

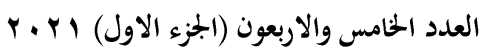

(267)

مجلة كلية التربية- جامعة عين شمس 
استخدام أسلوب بيرت PERT في تخطيط برنامج لتدريب فرق التخطيط الاستراتيجي في الجامعات المصرية

الثاني عشر: متابعة وتقويم البرنامج التدريبي:

ا ــ المتابعة الدورية اليوميـة للبرنـامج مـن قبـل هيئـة خاصـة مـن الجامعـة تكون بمثابـة

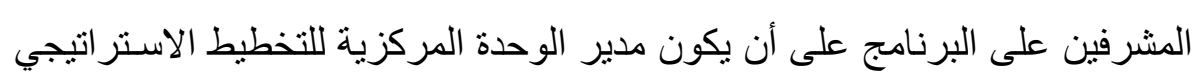

$$
\text { ونائبه أحد أعضائها. }
$$

r- نسبة حضور الفريق للبرنامج بمحاضر اته و أنشطته المختلفة بصورة منتظمة، وعلى من يتخلف عن الحضور ثناث أيام إعادة التدريب.

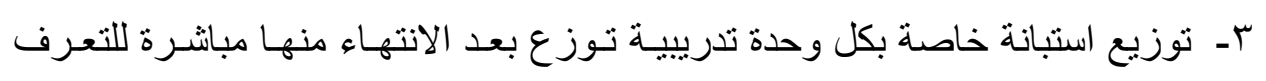

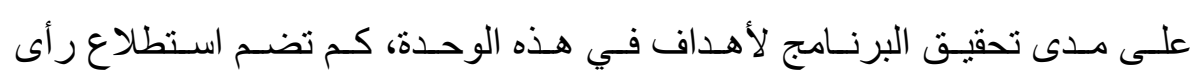

$$
\text { المتدربين في كفاءة المدرب. }
$$

عـ - تقويم أداء القريق من خلال مشاركتهم في حلقات المناقتنة وفي ورش العمل. هـ امتحان تحريري شامل لموضو عات البرنامج بعد الإنتهاء مـن تقديم محتوى الـدورة

$$
\text { التدريبية بيومين. }
$$

وبالتالي، تناول البحث إطـار تخطيطي مقتر ح لبرنـامج تـدريب وتأهيـل فريق التخطيط الاستر اتيجي بالجامعة وكلياتها، ولكي يحقق هذا البرنامج أهدافـه المرجوه بأقل

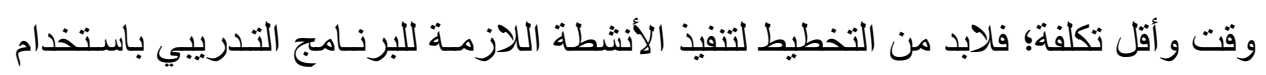
أسلوب بيرت.

المحسور الرابـع: اسـتخدام أسـلوب بيـرت فـي تخطيط برنـامج تـدريب فـرق التخطيط الاستراتيجي بالجامعات:

Program Evaluation and Review PERT يعـدبيـرت باجني

تقنية تقييم ومراجعة البرامج وهو أسلوب لتخطيط المشروع أو البرنـامج (technique) وجدولته يستخدمه فريق إدارة المشاريع في مجـالات مختلفــة. تم اقتر اح PERT لأول

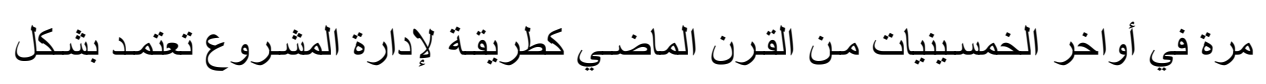

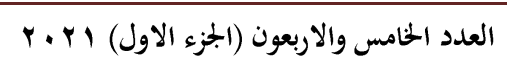

مجلة كلية التربية- جامعة عين شمس 


\section{د/ وفـاء عبد الفتــاح محمـود}

أساسي على توزيع بيتا نظرًا لبساطته ومرونته. (Sackey \& Kim, 2019, 1484)

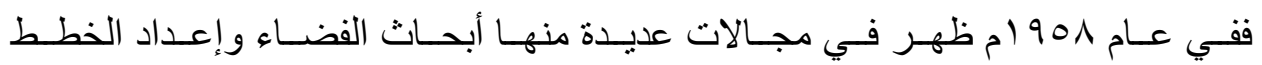
للمشـرو عات و البـر امج العــكرية و المدنيـة بهــف تخفيض الوقت المطلــوب لإنجـاز المشروع. و أثثيرت عدة اعتر اضات حول تركيز بيرت على الوقت فقط، حيث إن هنـاك

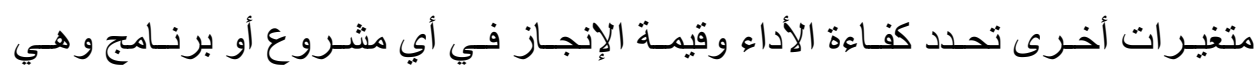
التكاليف التي تنفق على أداء كل نشاط من أنشطة المشروع وصـو لا إلى تحقيق أهدافه، ومن ثم ظهر الجناح الثاني من بيرت وهو بيرت/ التكلفة. وكانت وزارة الدفاع الأمريكية

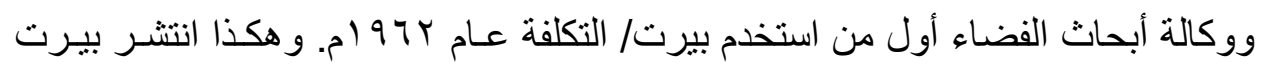

بشقيه بيرت/ الوقت، بيرت/ التكلفة في جميع مجالات الحياة. (السيد، بو99 (1، ؟9) ويعتبر أسلوب بيـرت " أسـلوب تخطيطي يستخدم في تحديد الأنشطة اللازمـة

لإنجاز برنامج ما، وتحديد تسلسلها وتتابعها وتمثيلها في صورة مخطط شـبكي مسع تقدير

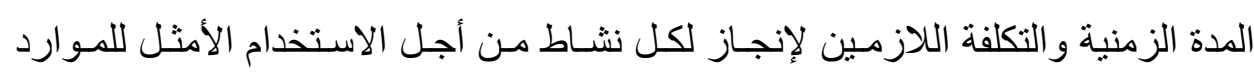

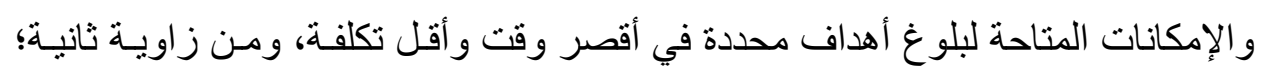

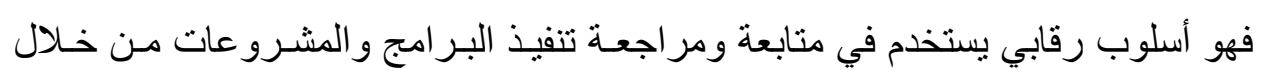

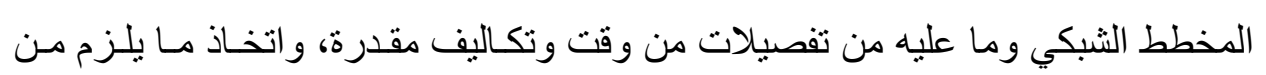

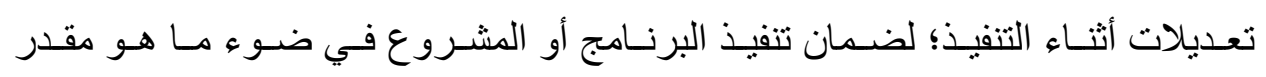

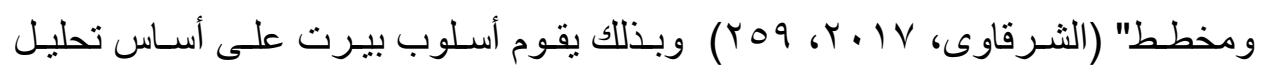
البرنامج أو المشروع إلى عدد مـن الأنشطة التي تتم في تتابع وتسلسل منطقي معين و التي يتطلب إنجاز ها زمنا وموارد مختلفة إلى أن يتم تنفيذ المشروع بأكمله. ويمكن تطبيق أسـلوب بيرت بشقيه في مجـالات ومشـرو عات تعليميـة متعددة،

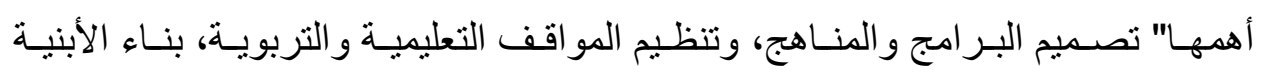

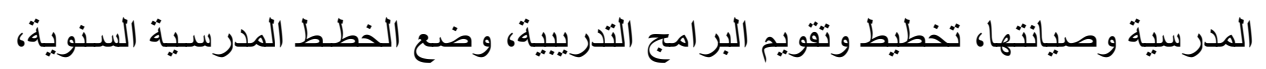


استخام أسلوب بيرت PERT في تخطيط برنامج لتتريب فرق التخطيط الاستراتيجي في

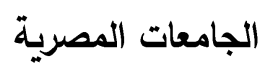

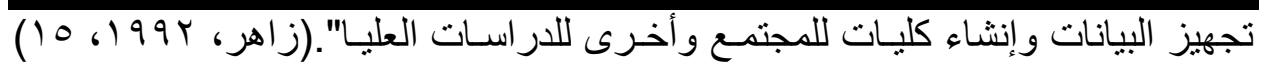
وتتضح كيفية تطبيق هذا الأسلوب على النحو النالي: أولاً: أساسيات تطبيق أسلوب بيرت: (الإطار الفكري)

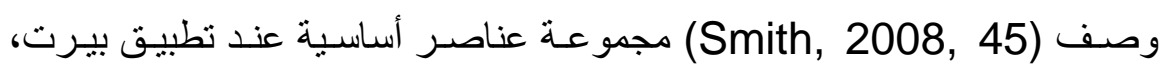

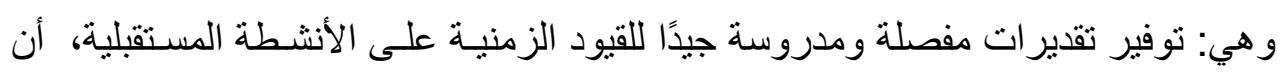

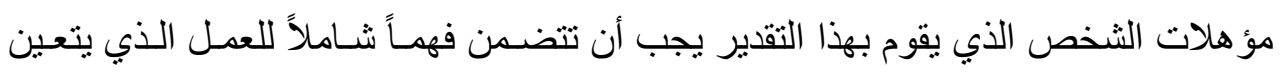

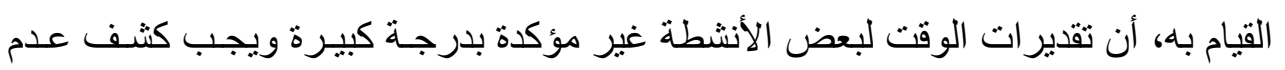

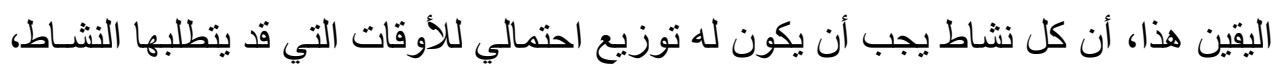
أنه يجب أن تكون هناك معرفة دقيقة بالتسلسل المطلوب أو الهخطط له في أداء الأنثطة.

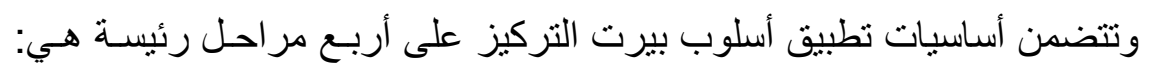

المرحلة الأولى: التخطيط وتتضمن هذه المرحلة أربع خطوات تتمثل في تحديد أهداف

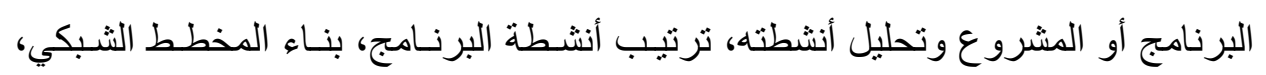

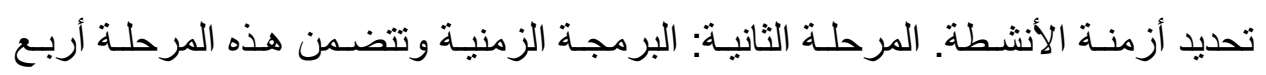

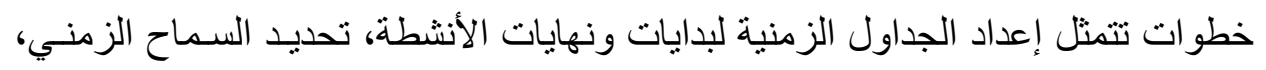

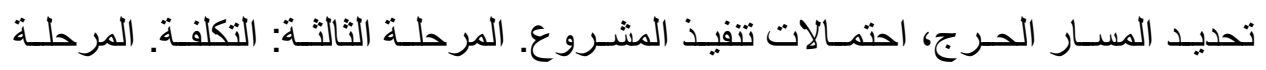

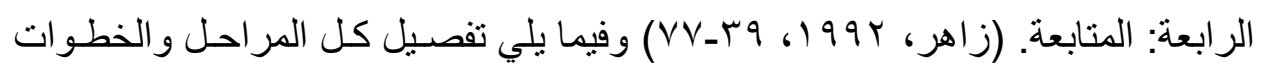
كما يلي:

\section{1- تحديد أهداف البرنامج وتحليل الأنثطة:}

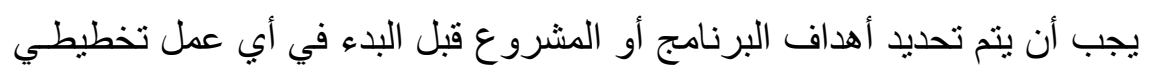

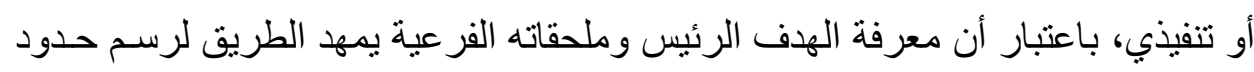

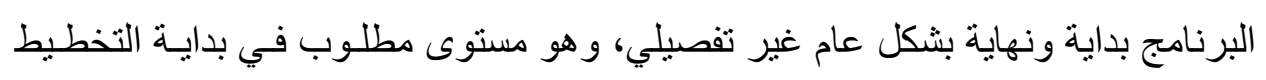

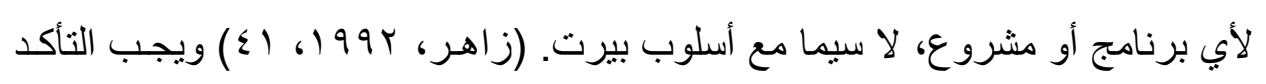

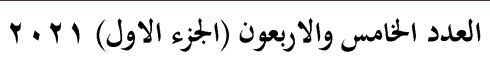

$$
\begin{aligned}
& \text { مجلة كلية التربية- جامعة عين شمس }
\end{aligned}
$$




\section{داء وفـاء عبد القتـاح محمـود}

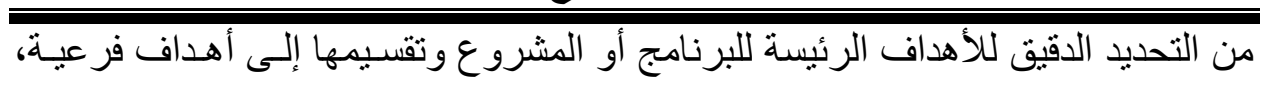

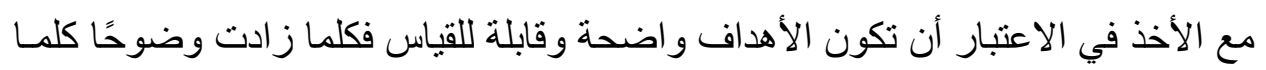

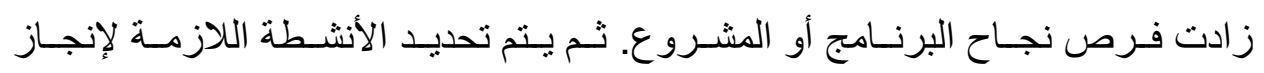

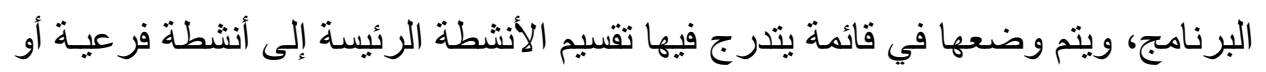

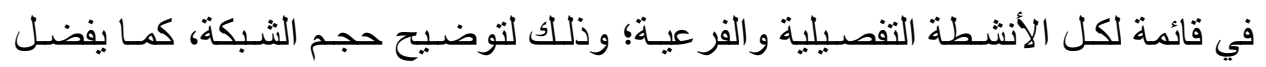
إعطاء رموز لهذه الأنشطة في هذه القائمـة لتسـهيل رسم الثبكات وخاصـة في حالـة

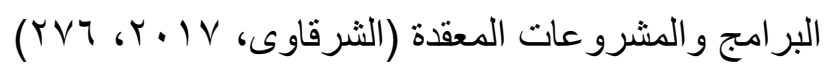

r- ت ترتيب أنشطة البرنامج:

لترتيب أنشطة البرنامج أو المشروع بشكل فعال ينبغي توافر عدد مـن الثـروط

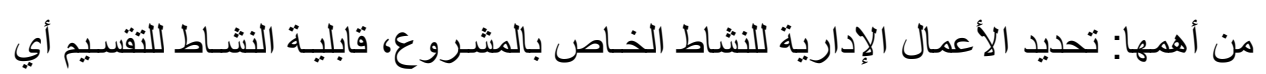

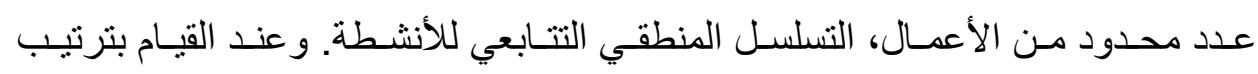
الأنشطة منطقيًا والتمهيد لترقيمها على المخطط الثبكي من الضروري طرح ثناث أسئلة رئيسة هي:

أـ ما النشاط (أو الأنشطة) الذي يجب أن يتم قبل بدء النشاط موضـع السؤال؟ ( تسـى

\section{الأنشطة السابقة).}

ب- ما النشاط (أو الأنشطة) الذي يجب أن يتم أثناء تنفيذ هذا النشـاط؟ ( تسـى الأنشـة المتوازية).

ج- ما النشاط أو الأنشطة الذي يجب ألا يبدأ قبل نهايـة هذا النشـاط؟ ( نسـى الأنشطة اللاحقة).

وبالإجابة عن هذه الأسئلة الثلاثة يكون المخطط في حالـة تسـح لـه بالبدء في

رسم الثبكة. يمكن استخدام المقابلات الثخصية أو أسلوب العصف الذهني في ترتيب الأنشطة مع التأكد على حضور خبر اء أو فنيون على درايـة تامـة بالعمليـات التفصيلية للبرنامج أو المشروع، ويدار حوار حول الأنشطة المطروحة ويطلب منهم الإسـهام مـن 
استخلام أسلوب بيرت PERT في تخطيط برنامج لتدريب فرق التخطيط الاستراتيجي في الجامعات المصرية فيطاية

خبرتهم بالأنشطة بطرح أفكار هم حول ترتيب هذه الأنشطة ثم يتم تنظيمها بعد ذلك في

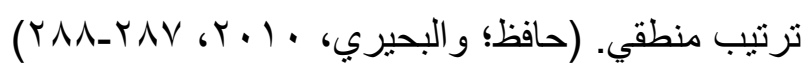
r- بناء المخطط الشبكي للبرنامج: لفهم بناء الثبكة جيدًا و هناك مصسطلحات مهمـة بهذا الأسـلوب، وهي: (غنيمـة،

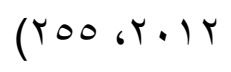

أ- الحدث: Event

الحدث هو لحظة زمنية تمثل إما بدء النشاط أو الانتهاء منه، وبعبارة أخرى هو

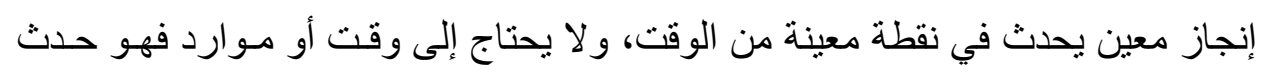

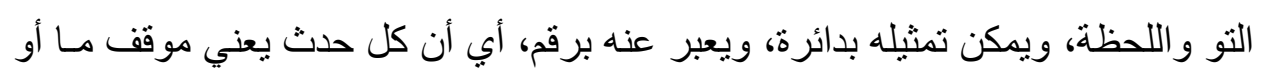
عمل ما لتحقيق أهداف البرنامج أو المشروع. بctivity بc باط النشاط يعرف بأنه: جهد مبذول لعمل شيء ما، ويستتفذ وقتًا ومالاً وجزءًا مـن الموارد،

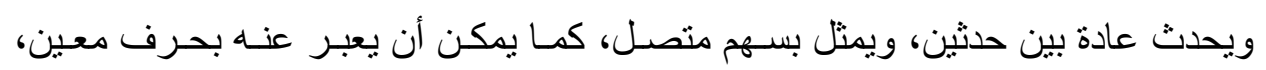

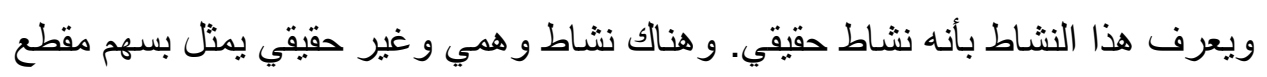

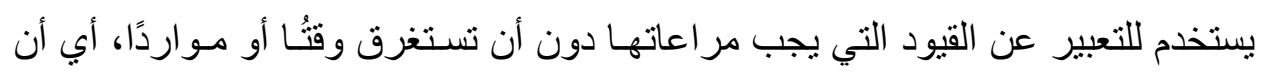

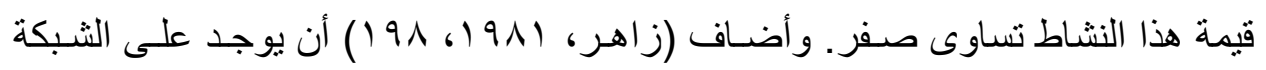
أنشطة انتظار لا تحتاج إلى الموارد ولكن تحتاج إلى الوقت ويرمز لهـا بالسـهم المتصـل.

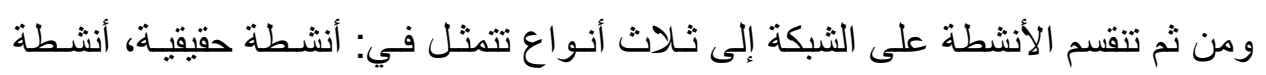

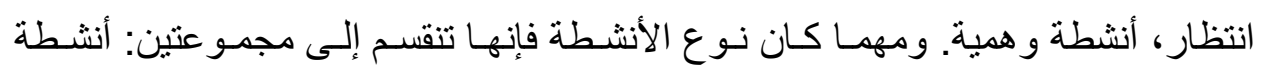
متعاقبة وهي تحدث في ترتيب متعاقب، أنشطة متوازية يتم تتفيذها في نفس الوقت. 


\section{ج- المسار: Path}

المسار هو مجموعة الأنشـة التي تصـل بين حدث البدايـة إلى حدث النهايـة.

و هنـاك مـا يسـي بالمسـار الحرج الذي يمثل أطول وقت في الثـبكة مـن بدايـة تنفيذ البرنامج حتى نهايته، وتعرف الأنشطة التي تقع على هذا المســار بالأنشطة الحرجـة. وطول المسار الحرج يعبر عن فترة الانتهاء من جميع أعمال الثـبكة، وتعد هذه الفترة هي أقل فترة زمنية ممكنة لإنجاز أهداف البرنامج أو المشروع. القواعد التي تزاعى عند رسم المخطط الثبكي: لكل شبكة حدث بداية واحد، وحدث نهاية واحد، على أن تتدفق في إتجـاه واحد فقط رئ

$$
\text { من حدث البداية إلى النهاية. }
$$

يفضل تمثيل الأنشطة بأسهر مستقيمة لا تأخذ شطل منحنيات أو تقاطعات أو أقو اسًا.

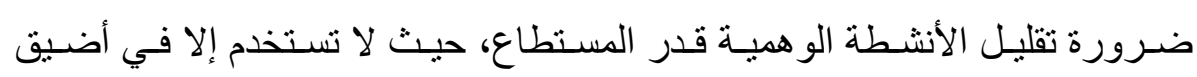
الحدود و عند تنفيذ الأنشطة المتوازية فقط.

ترميز الأنشطة المختلفة عن طريق أعطار رمز لكل نشاط يميزه عن بـاقي الأنشطة

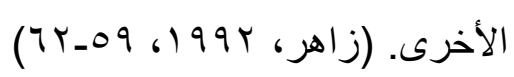

تجنب وجود حدث متدلى أو معلق في الثبكة فلابد من عمل نشاط وهمي لـه، حيث

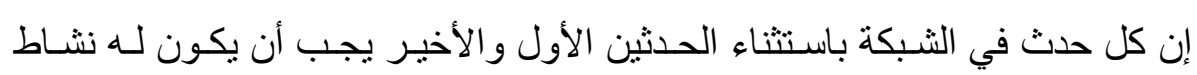
سابق ونشاط لاحق أو نشاط و همي ينصل بما يليه ويتم تمثيله بسهم متقطع.

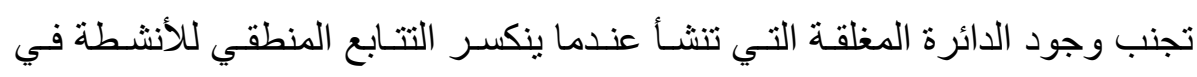

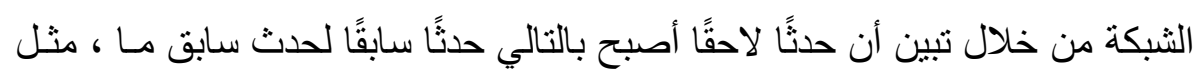
هذا الوضع غير منطقي، ومن ثم غير صحيح في المخطط الثبكي. عدم اتصال أي حدثين بواسطة أكثر من نشاط واحد، فلا يجوز تمثنيل النشـاط الواحد

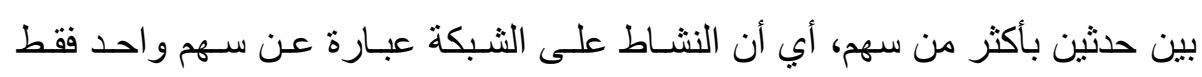

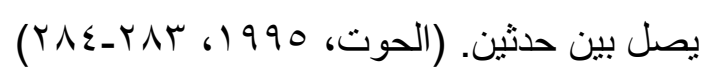

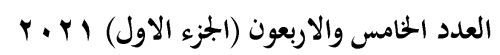

(273)
مجلة كلية التربية- جامعة عين شمس 
استخدام أسلوب بيرت PERT في تخطيط برنامج لتدريب فرق التخطيط الاستراتيجي في الجامعات المصرية

؛ـ تحديد أزمنة أنشطة البرنامج:

يتم استخدام عدد من الأزمنة لوضع تقديرات زمنية لكل نشاط وهذه الأزمنة هي:

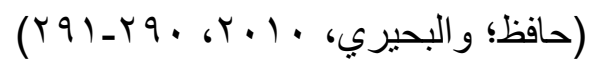

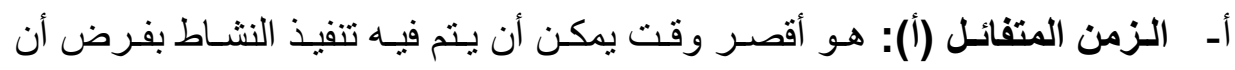
الظروف مواتية أي في حدود أقل عو ائق ممكنة أو ليس هنـاك مشكلات عمل أو

$$
\text { تأجيل في إعدادات أو غير ها. }
$$

بـ الزمن المتشائم( ب): هو أقصى وقت بمكن أن يتم فيـه تتفيذ النشـاط بفرض أن أن الظروف غير مواتية ما عدا الكوارث أي في وجود بعض مشكلات عمل أو تأجيل

$$
\text { في إعدادات. }
$$

ج- الزمن الأكثر احتمالاً (ج): هو الزمن الأرجح حدوثًا وهو وسط بين الإثنين، وهو أفضل التقديرات للوقت اللازم للانتهاء من النشاط.

د- الزمن المتوقع أو الممكن (م): هو الزمن المتوسط الذي يتطلبه تنفيذ النشاط إذا مـا

$$
\text { كرر تنفيذه مرات كثيرة. }
$$

و عندما يكون الفرق بين الأزمنة ثابت يكون منوسطهم هو الزمن الأكثر احتمالاً.

ويمكن إيجاد الزمن المتوسط مـن خـلال المعادلـة التاليـة: ,Chang, et. al, 2019)

2397-2398)

الزمن المتوقع = ( الزمن المتفائل+ ؛ الزمن الأكثر احتمالاً+ الزمن المتشائم)/ ج.

$$
\text { أي أن: }
$$

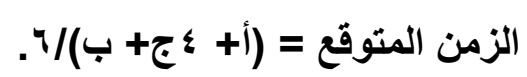

حساب الاحتمـالات المرتبطـة بهذه التقديرات لكل نشـاط إذا افترض أن الفترات

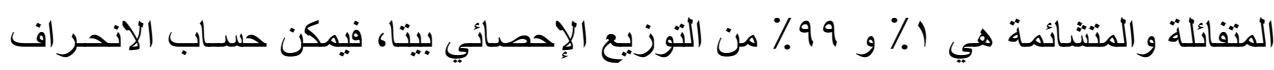

المعياري باستخدام المعادلة التالية: (Chang, et. al, 2019, 2397-2398)

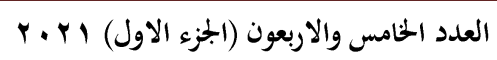

(274)

مجلة كلية التربية- جامعة عين شمس 


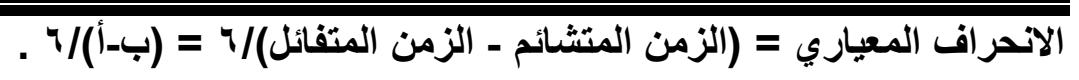

عندما يكون هناك فروق كبيرة بين الزمن المتفائل(أ) والزمن المنتـائُ(ب)، فإنـه من المحتمل أن يكون هناك قدر كبير من عدم التأكد من الزمن المتوقع(م)، و عندما تكون نتيجة التباين بسيطة، فإن تقدير الزمن المتوقع(م) سوف يكون دقيقًا بدرجـة مـا، ويمكن حسـاب التبـاين مـن خـلال حسـاب الانحـر اف المعيـاري ثم ثربيعـهـ. إذا كـان الانحـر اف المعياري يساوي صفر فيدل ذلك على أن التقديرات دقيقة، و إذا كبـرت قيمـة الانحـر اف المعياري، ز ادت درجة عدم اليقين في تقدير الأزمنـة، وبالتـالي الفرصـة كبيـرة جدًا أن

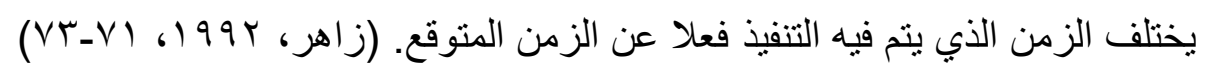
هـ تحديد أوقات البدء والانتهاء المبكرة والمتأخرة للأنشطة: بعد تخطيط الأنشطة وتحديد الخطة الأوليـة لسـير العمل وفقًا للأزمنـة المتوقعـة للأنشطة ( بناء المخطط الثبكي)، يتم تحديد زمن البداية والنهايـة لكل نشـاط على حده وذلك للحصـول على الجدول الزمنـي المتكامـل للبرنـامج. وهنـاك نـوعين مـن الأوقـات

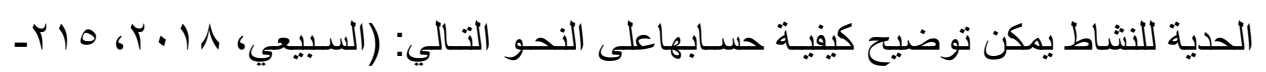

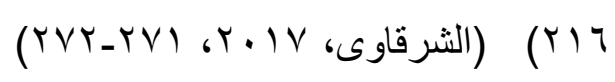

\section{أـ بلايات ونهايات مبكرة:}

البداية المبكرة: هو أقرب وقت ممكن لبدء نشـاط مـا، أي هـ الزمن الذي يبدأ فيـه

$$
\text { النشاط إذا انجزت جميع الأنشطة السابقة في أوقاتها. }
$$

النهاية المبكرة: هو أقرب وقت ممكن لإنهاء نشاط مـا، أي هو الزمن الذي بنتهي

$$
\text { فيه النشاط إذا بدأ في وقته المبكر. }
$$

ب- بلدايات ونهايات متأخرة:

• البداية المتأخرة: هو أخر وقت ممكن لبداية نشاط ما دون أن بـؤدي ذلك إلى تـأخير

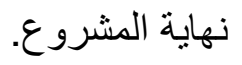


استخدام أسلوب بيرت PERT في تخطيط برنامج لتدريب فرق التخطيط الاستراتيجي في الجامعات المصرية فيطاية

• النهاية المتأخرة: هو أخر وقت ممكن لإنهاء نشاط ما بشرط ألا يؤثر ذلك على موعد

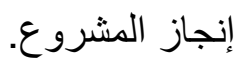

وتحسـب أوقـات البـدء و الانتهـاء المبكرة و المتــأخرة باسـتخدام الوقت المتوقـع

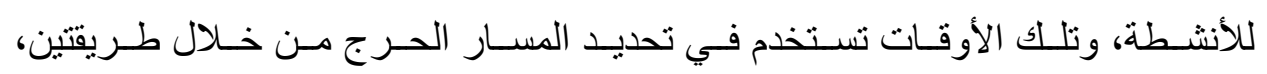

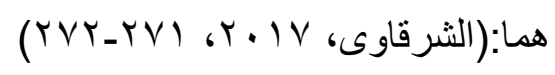

الطريقة الأولى: الحسابات الأمامية (الزمن الأكبر): يتم من خلالها حسـاب الأوقـات المبكرة للبدء والاتتهاء للنشاط، وفي هذه يكون:

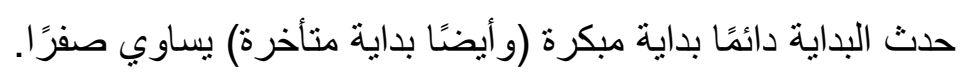

النهاية المبكرة لنشاط ما= البداية المبكرة للنشاط + مدة النشاط.

في حالة حساب النهاية المبكرة لنشاط ما وتوجد أكثر من نهاية مبكرة تسبقه فإنه

$$
\text { يتم اختيار النهاية المبكرة الأطول زمنًا. }
$$

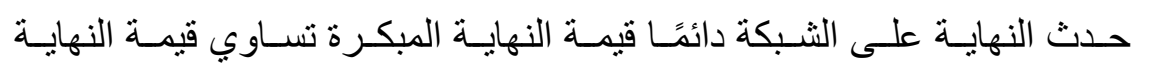

$$
\text { المتأخرة. }
$$

الطريقـة الثانيـة: الحســابات الخلفيـة ( الـزمن الأصـغر): يـتم مـن خلالهـا حسـاب الأوقات المتأخرة للبدء والانتهاء للنشاط، وفي هذه يكون:

•البداية المتأخرة = النهاية المتأخرة - مدة النشاط

• في حالة حساب البداية المتأخرة لنشاط ما وتوجد أكثر من بدايـة متأخرة للنشـاط ملاط

اللاحق فإنه يتم اختيار البداية المتأخرة الأقل زمنًا.

$$
\text { وقت إنجاز المشروع= أوقات الإنتهاء لجميع الأنشطة. }
$$




\section{دام/ وفـاء عبد القتــاح محمـود}

ד- - تحديد فترة السماح أو الوقت الفائض وتحديد المسار الحرج:

يقصد بفترة السماح الوقت الذي يمكن للنشاط أن يتأخر في حدوده دون أن يؤثر ذلك على الجدول الزمني للمشروع ككل ويتم حسابه بطريقتين، هـا: ( زايد؛ وآخرون، $($ ) $Y \wedge, Y \cdot Y \cdot$ السماح = البداية المتأخرة لنشاط ما - البداية المبكرة له. أو السماح = النهاية المتأخرة لنشاط ما - النهاية المبكرة له. وكلاهما متساويان في فترة السماح. أمسا المسـار الحـرج هـو أطسول مسـار للأنشـطة على الثـبكة مـن حـدث بدايـة المشروع إلى حدث النهاية، أو هو المسار الأكثر استنفاذًا للوقت على الثبكة منـذ البدايـة

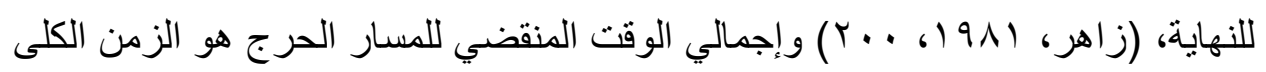

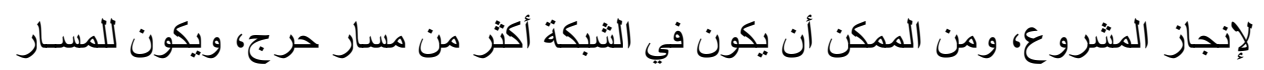

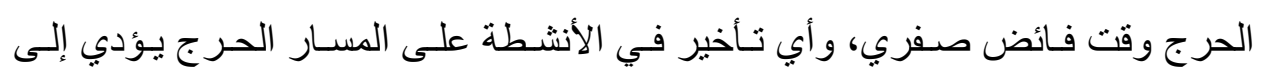
تأخير مماثل في استكمال المشروع. (Gass \& Fu, 2013, 313) فالأنشطة الحرجة هي التي يجب أن تتم في المو اعيد المحددة لها إذا مـا أريــ للمشروع أن يـتم تنفيذه طبقًا

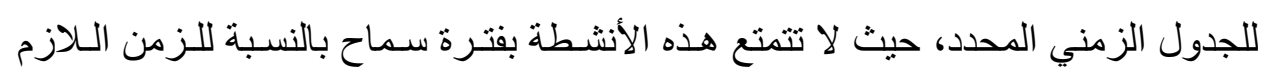

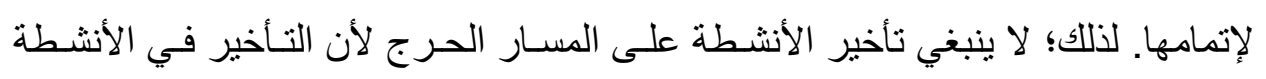

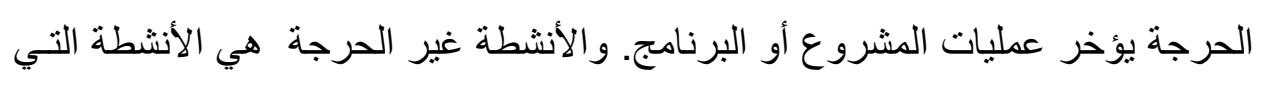

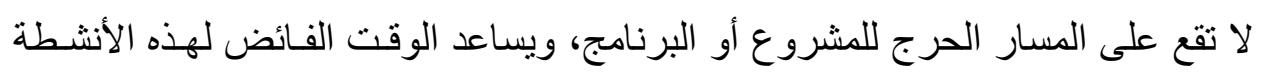
على تحديد المرونة في الجدولة الزمنية للمشروع. (Girija \& Bhat, 2013, 359)

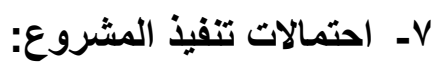
يمكن تقدير احتمالية إنجاز المشـروع في فتـرة زمنيـة معينـة مـن خـلال المعالـة

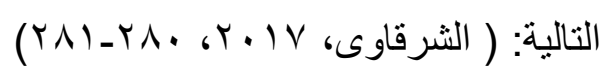

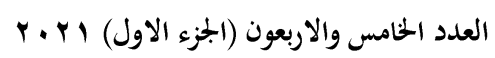

(277)

مجلة كلية التربية- جامعة عين شمس 
استخام أسلوب بيرت PERT في تخطيط برنامج لتتريب فرق التظطيط الاستراتيجي في

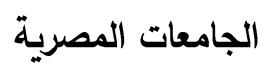

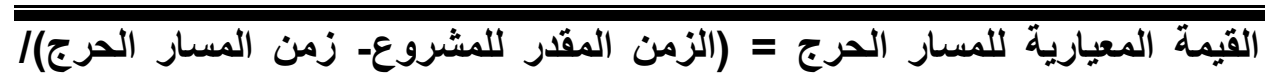
الجذر التربيعي مجموع التباين للتقيرات الزمنية للأنثطة الحرجة. ثم يتم استخراج القيمة المعيارية من جدول التوزيع الطبيعي وتكون هي إحتمـال إنهاء المشروع عند تلك النقطة.

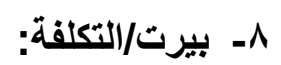

يعتمد أسلوب بيرت/ التكلفة في تخطيط البرامج على تقسيم البرنامج إلى أنثطة،

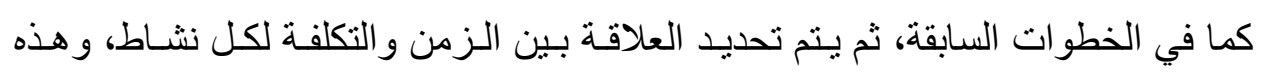

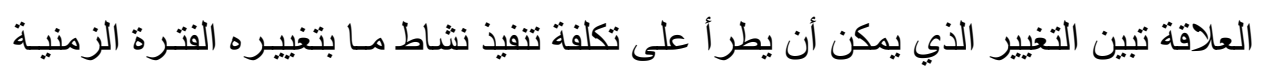

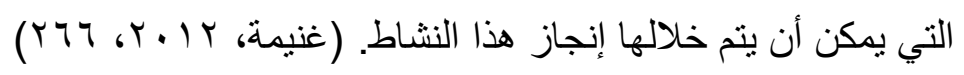

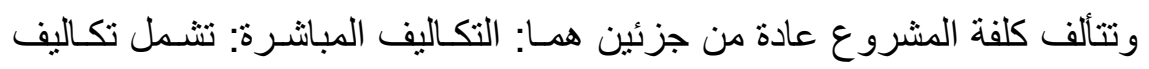

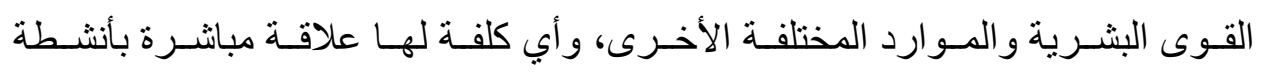

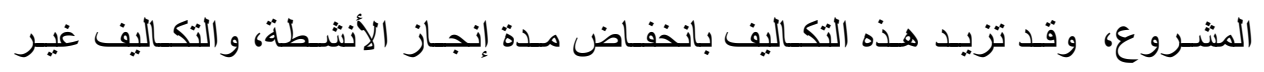

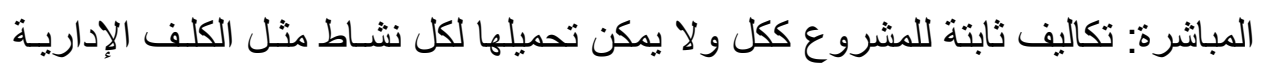

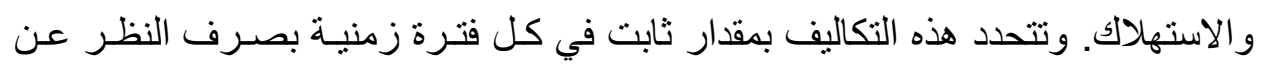

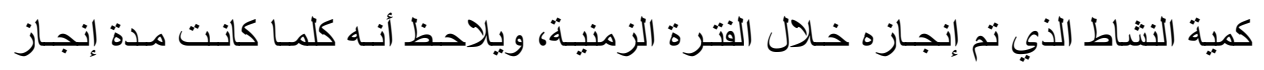

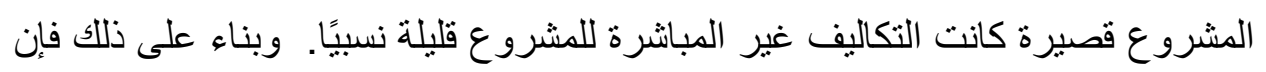

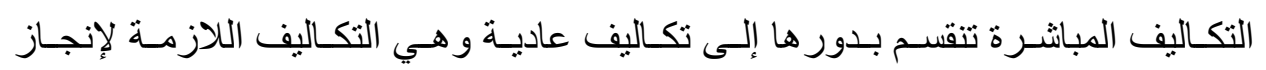

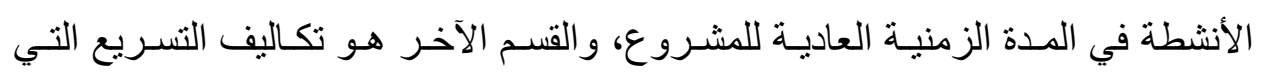

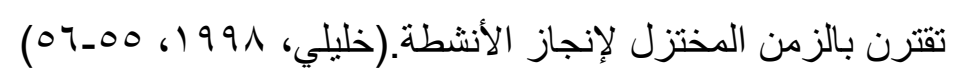

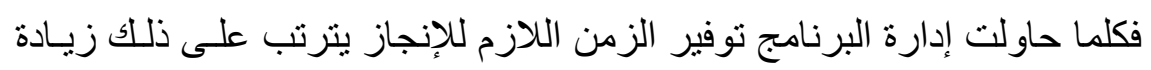

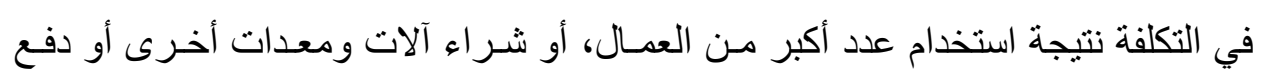

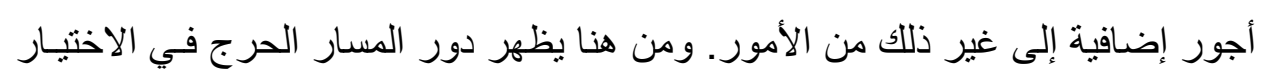

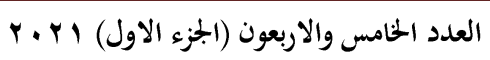

$$
\begin{aligned}
& \text { مجلة كلية التربية- جامعة عين شمس }
\end{aligned}
$$




\section{د/ وفــاء عبد الفتــاح محمـود}

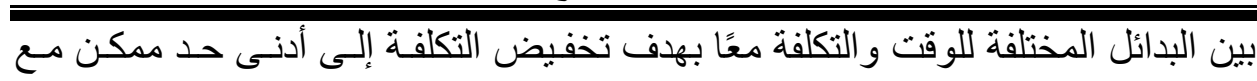
تحقيق إنجاز المشروع في التاريخ المطلوب في ضـوء الإمكانـات المتاحسة، ويجب عند المفاضلة بين البدائل المتاحة بهدف تخفيض التكلفة إلى أدنى حد ممكن على أساس انتهاء الجهاء العمل خلال المدة المحددة. فاذا كانت التكلفة أقل ما يمكن ولكن العمل بينتهي بعد الوقت إتى

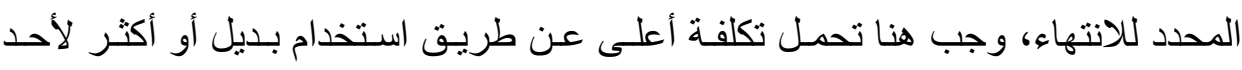
الأنشطة الو اقعة على المسار الحرج. ومن ثم يوجد نو عين من التكلفة العادية و هي التكلفة اللازمة لتنفيذ النشاط خلال الوقت العـادي، وتكلفـة التسـريع وهـي التكلفـة للازمـة لتنفيذ النشاط في وقت أقل من الوقت العادي.(الموافي، 9 19 1) 1) ويمكن حساب مقدار التغيير في التكلفة نتيجة التسريع و التي تستخدم على أسـاس

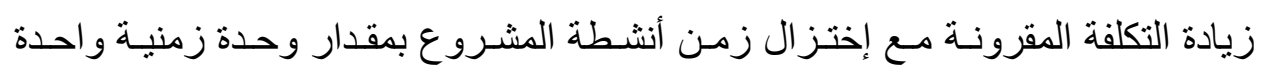

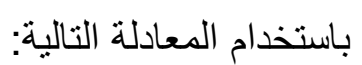

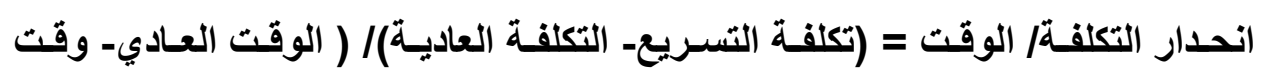
(التسريع).

أي أن ميل التكلفة الخاص بكل نشاط يثير إلى التكلفة المباثـرة الإضـافية التـي

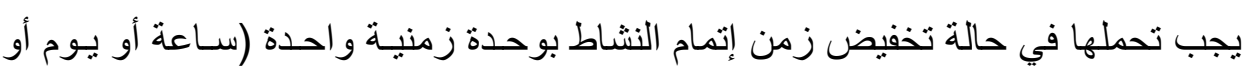

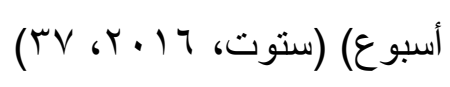

ويمكن توضيح خطوات المفاضلة بـين زمسن وتكـاليف المشـروع على النحو التـالي:

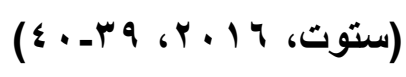

أــ تحديد الزمن العادي (الزمن الممكن المحسوب) وزمـن التعجيـل الممكن لكل نثـاط

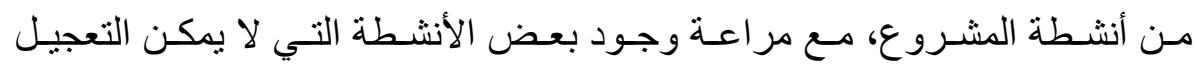

$$
\text { بإنجاز ها فنيًا. }
$$

ب- تحديد التكلفة المباشرة العادية وتكلفة التعجيل المباشرة الخاصة بكل نشاط من أنشطة

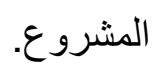

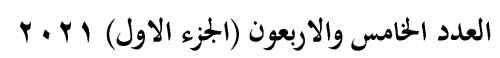

(279)
مجلة كلية التربية- جامعة عين شمس 
استخدام أسلوب بيرت PERT في تخطيط برنامج لتدريب فرق التخطيط الاستراتيجي في الجامعات المصرية فيطاية

ج- تحديد التكاليف غير المباشرة المرتبطة بزمن المشروع الكلي.

د- تحديد المسار الحرج و الأنشطة الحرجة ومن ثم تحديد الزمن المبدئي الـلازم لإنجـاز

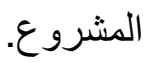

ه- حساب التكلفة المبئية الإجمالية للمشروع وفقًا للمعادلة التالية:

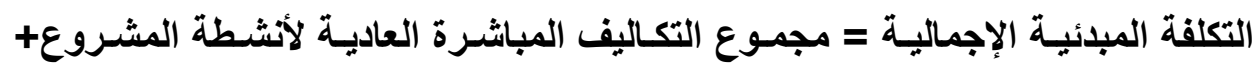
(الزمن المبئي للمشروع x التكلفة غير المباشرة اللازمة للوحدة الزمنية الواحدة). و - حساب ميل التكلفة الخاص بكل نشاط من أنشطة المشروع. ز- اختيار النشاط المناسب الذي يتم تخفيض زمـن إنجـازه، و هنـا يجب مر اعـاة اتبـاع

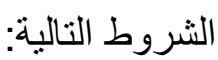
• أن أن يكون نشاطًا حرجًا.

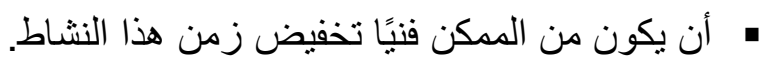
• أن تكون تكلفة التخفيض بمقدار وحدة زمنية واحدة أقل ما بمكن. ح- إعادة تحديد المسار الحرج، حيث عند تخفيض زمن المسار الحرج السـابق فإنـه مـن الممكن أن يصبح أقصر من أحد المسـارات الأخـرى على الثـبكة، وهنـا يـتم إعـادة حساب زمن المشروع. (مان. ط- إعادة حساب التكلفة الإجمالية للمشروع، مع مر اعاة ما يلي:

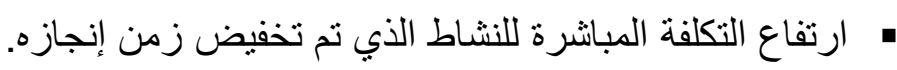
• انخفاض التكلفة غير المباثرة للمشروع. ي- يتم الاستمرار باختيار أنشطة المسار الحرج التي يتم تخفيضـها مـع ملاحظـة التغير

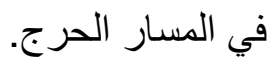




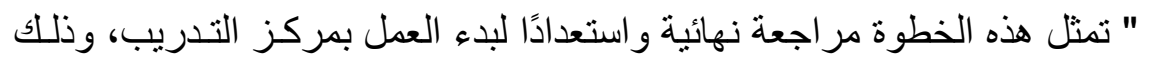
بهـدف التأكد مـن قابليـة شبكة الأعمـال و الجدول الزمنـي للتنفيذ، و التأكدـ مـن أن نظـام الاتصـال بـين المخططين و المنفذين للثـبكة يسـمح بتـدفق المعلومـات بكفـاءة وفعاليـة، ومواءمة شبكة الأعمال باستمر ار للتغيرات في الوقت، وزيـادة المعلومـات (كمـا وكيفًا) عن كل مرحلة من مراحل العمل كلمـا اقترب موعد تتفيذها، بالإضـافة إلى استـمر ار تطوير شبكة الأعمال بناء على تلك المعلومات. ومرجع ذلك أن عملية التخطيط بطبيعتها

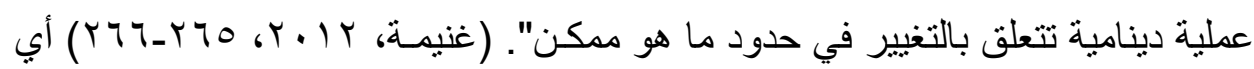

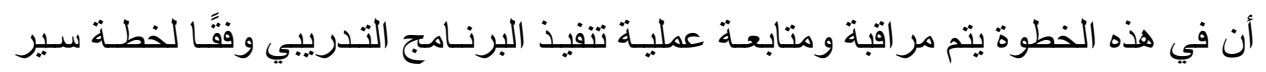

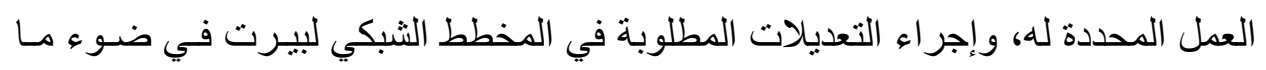
بطر أ من مستجدات.

ثانيًا: خطة مقترحة لتنفيذ برنامج تدريب فرق التخطيط الاستراتيجي بالجامعات المصرية:

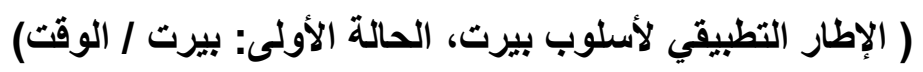

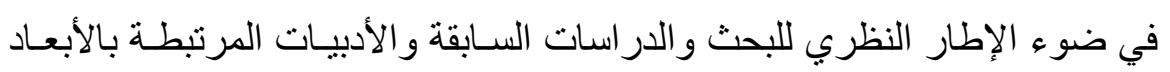
الأساسية للبر امج التدريبية وكذلك مسح للار اسـات التي تناولت كيفيـة تخطيط المؤسسـات الجديـدة باسـتخدام أسـلوب بيـرت تـم إعداد قائمـة بالأنشــة المسـتقبلية الرئيســة للبرنـامج

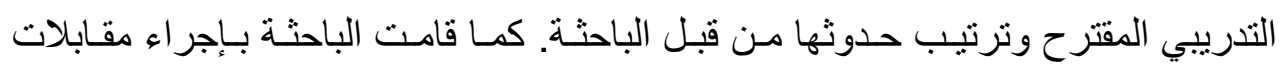

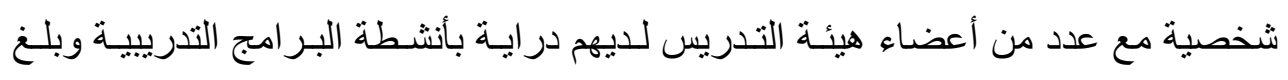

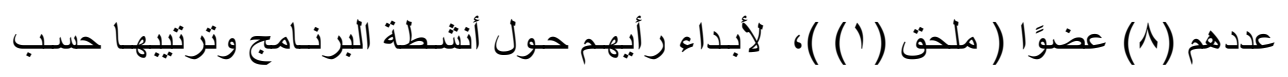

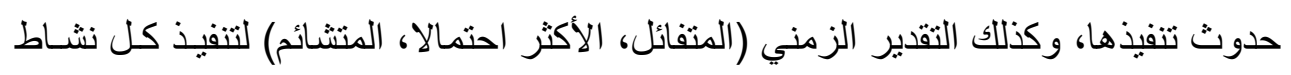
على حدة. وفي ضوء ما سبق تمكنت الباحثة من تجميع وترتيب الأنشطة الرئيسة التي تهم خطة البرنامج موضوع البحث في خطوطه العريضة و التفصيلية والتقدير وات الزمنيـة لكل 


\section{استخدام أسلوب بيرت PERT في تخطيط برنامج لتدربب فرق التخطيط الاستراتيجي في الجامعات المصرية فيطاية}

نشاط بشكل منطقي وو اقعي. ويتضح المخطط الثبكي للبرنامج التدريبي المقترح و احتمالية تنفيذه من خلال خطوات تطبيق أسلوب بيرت السابق عرضها كما يلي:

ا - قائمة الأنشطة وترتيبها:

قائمة تفصيلية بأرقام الأحداث و الأنشطة الرئيسة اللازمة لتنفيذ البرنامج التدريبي

المقترح، ووصف لمكونـات كل نشـاط على حدة وكذلك ترتيب هذه الأنشطة والجهة المسئولة، كما بتضح في الجدول التالي:

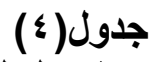

أنشطة برنامج تدريب فرق التخطيط الاستراتيجي بالجامعات

\begin{tabular}{|c|c|c|c|c|c|c|}
\hline المسئولة & النشاطق & وصف مكونات النشاط & & النشاط & النشاط & رقدث \\
\hline رائيس مجلس & ل ل الايوجد & & & 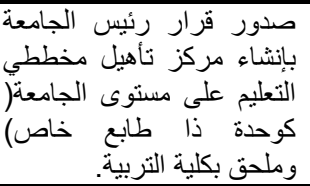 & أ & 1 \\
\hline رالكلية مجلس & أ & & & 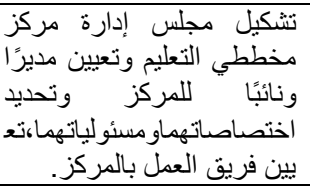 & ب & r \\
\hline مخطير مركز & 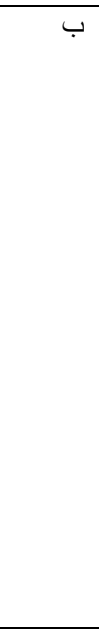 & 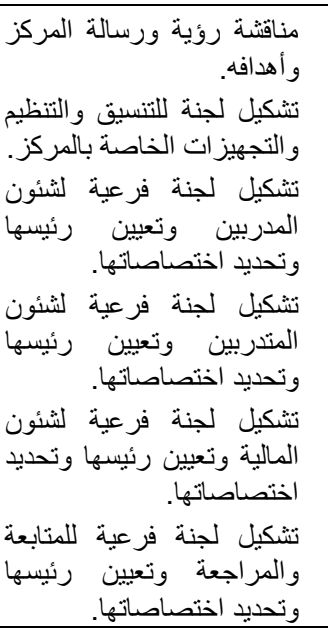 & - & 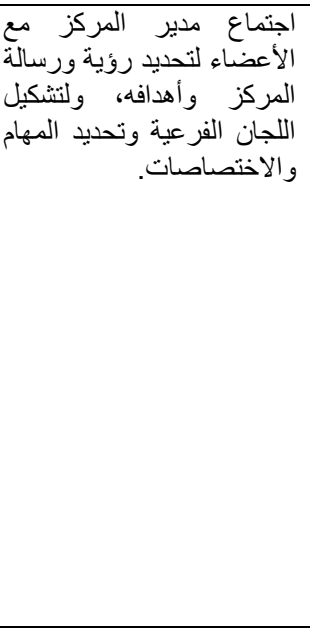 & ج & $r$ \\
\hline رإدئيس المركزلس & ج & إقرار رؤية ورسالة المركز & - & مخططي التعليم واعتمادها الإدارية لمركز & د & $\varepsilon$ \\
\hline
\end{tabular}

العدد الخامس والاربعون (الجزء الاول) ب. r.

(282)

مجلة كلية التربية- جامعة عين شمس 
د/ وفـاء عبد الفتــاح محمـود

\begin{tabular}{|c|c|c|c|c|c|}
\hline المسئولة & النشابق & وصف مكونات النشاط & النشاط & النشاط & الحدث \\
\hline المريد الكلية & & 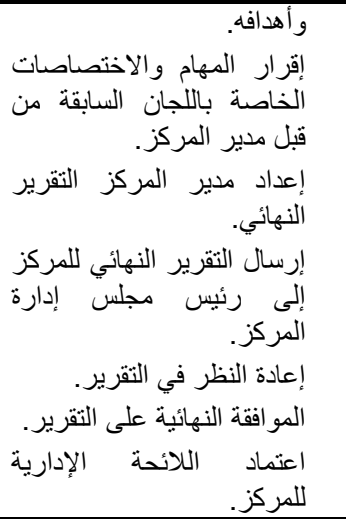 & & & \\
\hline إدئيس مجلس المركز & د & 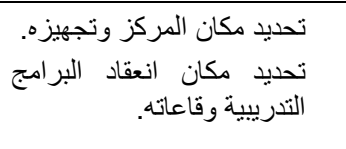 & وانعقاد البرنامج التدريبي مكان المركز & 。 & 0 \\
\hline 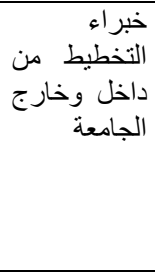 & 。 & 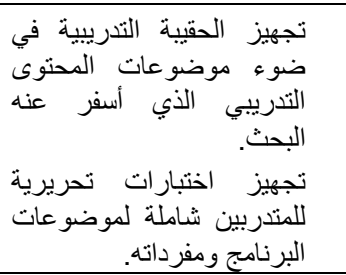 & 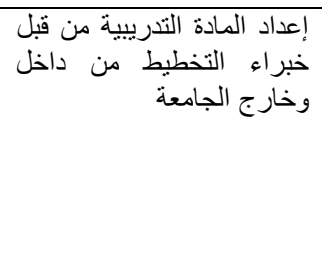 & 9 & 7 \\
\hline 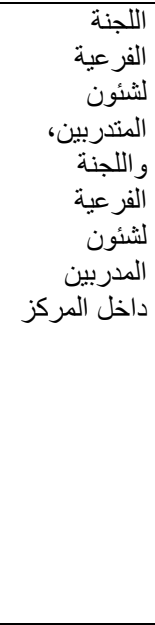 & 。 & 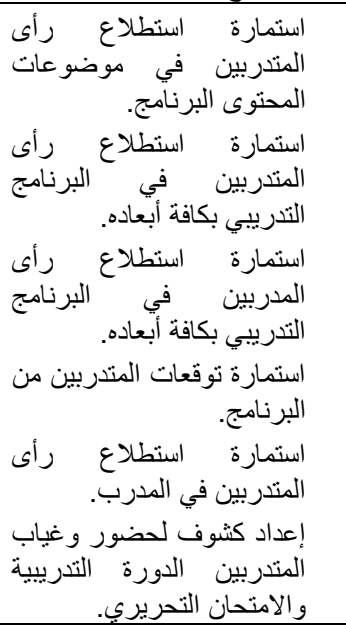 & إعداد ملفات التقويم & j & $V$ \\
\hline الفئرن & 0 & 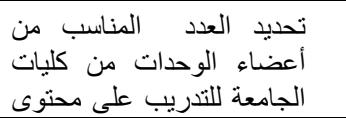 & وحدات التخطيط الاستر اتيجي أعضاء & $\tau$ & 1 \\
\hline
\end{tabular}




\section{استخدام أسلوب بيرت PERT في تخطيط برنامج لتدريب فرق التخطيط الاستراتيجي في الجامعات المصرية}

\begin{tabular}{|c|c|c|c|c|c|}
\hline المسئولة & النشابق & وصف مكونات النثاط & النشاط & النشاط & رقدث \\
\hline داخل المركز & & 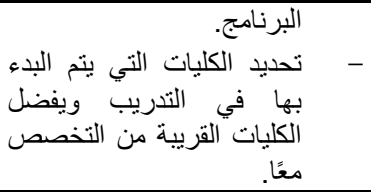 & & & \\
\hline واللجنة & $\tau$ & & 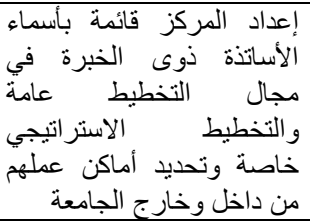 & $\bar{b}$ & 9 \\
\hline 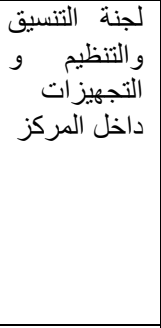 & و & 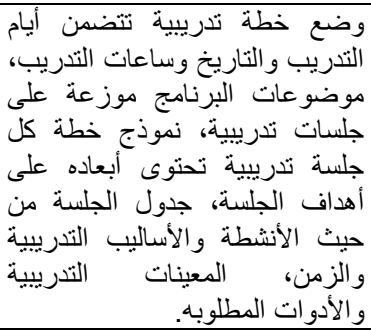 & إعداد خطة تدرييية & ي & $1 \cdot$ \\
\hline 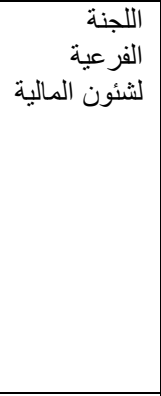 & b، j، j & 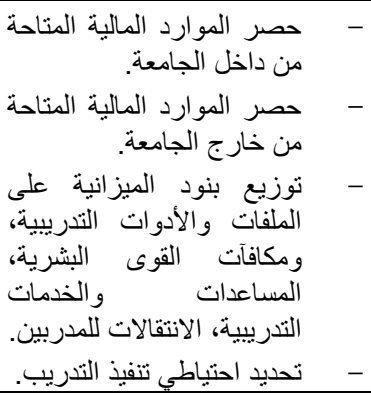 & إعداد ميز انية التدريب & ك & 11 \\
\hline |إدارة المركز ، ومدير & 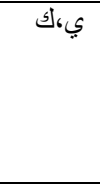 & & 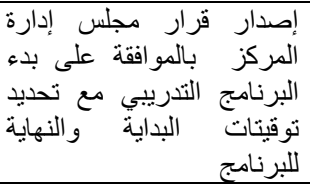 & J & IT \\
\hline المدير المركزئة المنئونية & J & 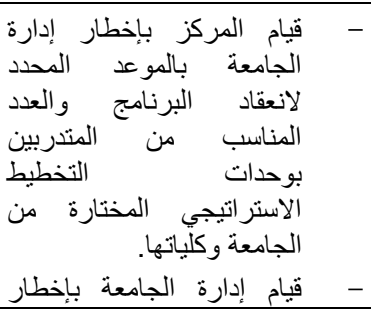 & اختيار ومخاطبة المتدربين & 5 & IT \\
\hline
\end{tabular}

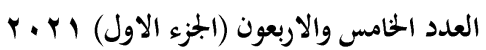

(284)

مجلة كلية التربية- جامعة عين شمس 
د/ وفــاء عبد القتــاح محمـود

\begin{tabular}{|c|c|c|c|c|c|}
\hline المسئولة & النشابق & وصف مكونات النشاط & النشاط & النشاط & رالحثث \\
\hline & & 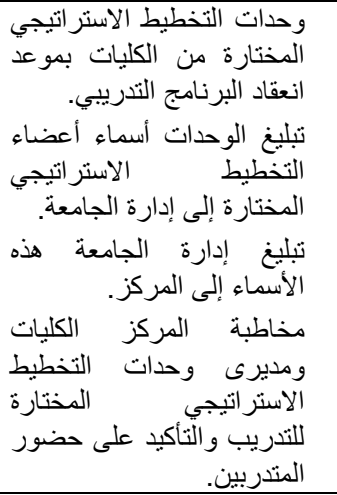 & & & \\
\hline 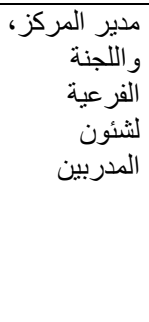 & J & 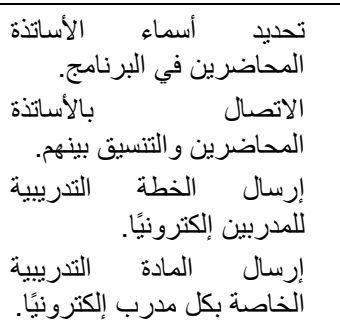 & اختيار ومخاطبة المدربين & ن & $1 \leq$ \\
\hline اللفئز اللجنة & ن & & التنام كل مدرب كل جلسة تدربيبة تنبية & س & 10 \\
\hline الشئون الفية & س - س & 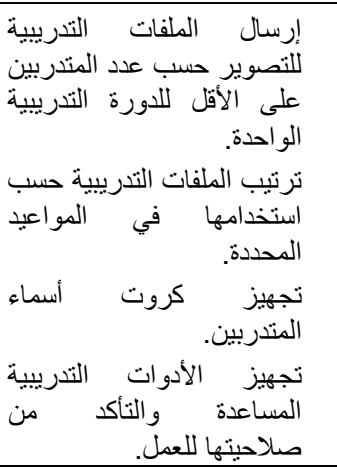 & 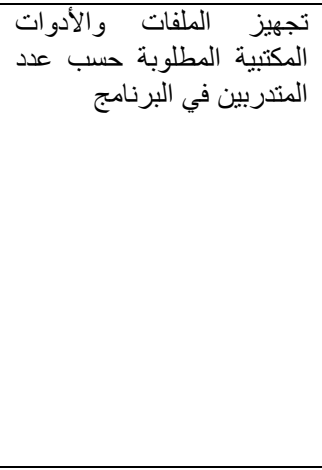 & $\varepsilon$ & 17 \\
\hline الجنالنة التنسيق & 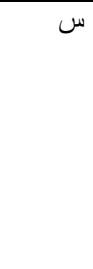 & 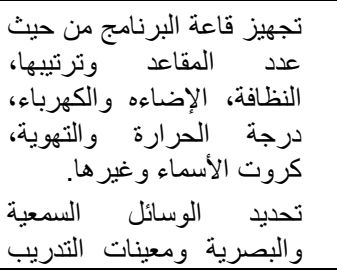 & إعداد مكان وقاعة التدريب & ف & IV \\
\hline
\end{tabular}

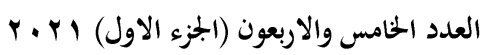

(285)

مجلة كلية التربية- جامعة عين شمس 


\section{استخدام أسلوب بيرت PERT في تخطيط برنامج لتدريب فرق التخطيط الاستراتيجي في الجامعات المصرية}

\begin{tabular}{|c|c|c|c|c|c|}
\hline المسئولة & النشابق & وصف مكونات النشاط & النشاط & النشاط & رقدث \\
\hline & & 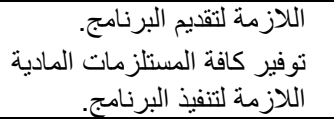 & & & \\
\hline 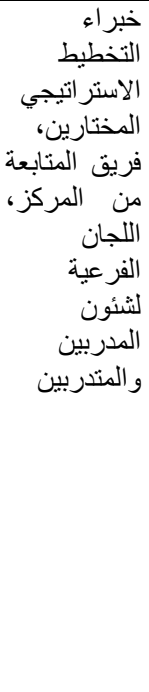 & ع، & 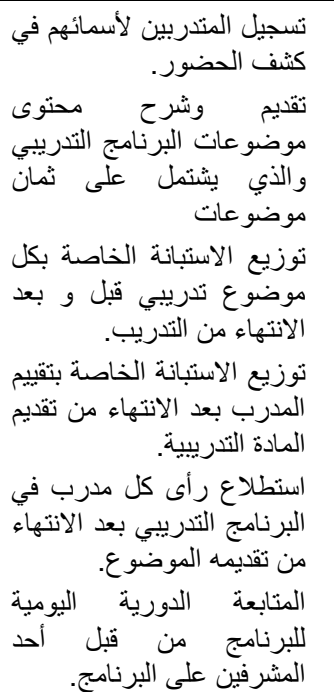 & تقديم ت محتوى $\quad$ البرنامج & ص & 11 \\
\hline 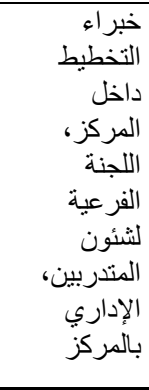 & ص & 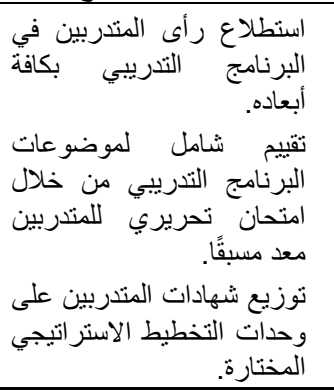 & ختام البرنامج التنديبي & ق & 19 \\
\hline
\end{tabular}

أن الأنشطة الرئيسة اللازمة لتنفيذ برنسامج تدريب فرق التخطيط الاستراتيجي مـع تقديم أول دورة تدريبية هي حسب ترتيب الأحداث: (أ) صدور قرار رئيس الجامعـة بإنشاء مركز تأهيل مخططي التعليم على مستوى الجامعـة ملحق بكليـة التربيـة، ثم (ب) تشكيل مجلس إدارة مركز مخططي التعليم وتعيين مديرًا ونائبًا للمركز وتحديد 
اختصاصاتهما ومسـئولياتهما وتعبينين فريتق العمل بـالمركز، ثـم (ج) اجتمـاع مـدير المركز مع الأعضاء لتحديد رسالة ورؤية المركز وأهدافه ولتشـكيل اللجـان الفرعيـة وتحديـد المهـام والاختصاصـات، ثـم (د) إقـر ار اللائحسة الإداريـة لمركز مخططي التعليم و اعتمادها، ثم (ه) اختيار وتجهيز مكـان المركز و انعقـاد البرنـامج التدريبي (و) إعداد المادة التدريبية من قبل خبر اء التخطيط مـن داخل وخـارج الجامعـة، (ز) إعداد ملفات التقويم، (ح) حصر المركز عدد أعضـاء وحدات التخطيط الاسـتراتيجي إني بالجامعة وكلياتها، (ط) إعداد المركز قائمة بأسماء الأسـاتذة ذوى الخبـرة في مجـال التخطـيط عامـة و التخطيط الاسـتر اتيجي خاصــة وتحديـد أمـاكن عملهـم مسن داخـل وخارج الجامعة، (ي) إعداد خطة تدريبية، (ك) إعداد ميز انية التدريب، (ل) إصـدار قرار مجلس إدارة المركز بالموافقة على بدء البرنامج التدريبي مـع تحديد توقيتـات البدايـة والنهايـة للبرنـامج، (م) اختبـار ومخاطبـة المتـدربين، (ن) اختيـار ومخاطبـة المدربين، (س) استلام خطة الجلسة التدريبية من كل مدرب قبل تنفيذ التدريب بوقت مناسب، (ع) تجهيز الملفـات والأدوات المكتبيـة اللازمسة حسـب عدد المتدربين في مي مئه البرنامج، (ف) إعداد قاعة التدريب، ( ص) تقديم محتوى البرنامج التدريبي ومتابعـة

$$
\text { تتفيذه، (ق) ختام البرنامج التدريبي. }
$$

أن الأنثطة التي يتم تتفيذها على التوازي هي: أثتـاء (و) إعداد المـادة التدرييـة مـن قبل خبر اء التخطيط يتم (ز) إعداد ملفات التقويم و(ح) حصـر عدد أعضـاء وحدات التخطيط الاستر اتيجي بالجامعة وكلياتهـا ثم (ط) إعداد قائمسة بأسـماء الأسـاتذة ذوى الخبرة في مجال التخطيط وتحديد أماكن عملهم. وأثتــاء (ي) إعداد الخطـة التدريبيـة يتم (ك) إعداد ميز انية التدريب معًا في نفس الوقت. و وأثتـاء (م) اختيـار المتدربين ومخـاطبتهم بـتم (ن) اختيـار ومخاطبـة المـدربين. (ع) تجهيـز الملفـات و الأدوات المكتبية المطلوبة في البرنامج و(ف) إعداد قاعة التدريب معًا في نفس الوقت. 
استخدام أسلوب بيرت PERT في تخطيط برنامج لتدريب فرق التخطيط الاستراتيجي في

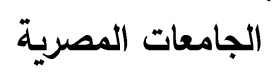

• أن الأنشطة أ، ب، ج، د، ه هي أنشطة متتالية تحدث في ترتيب متعاقب ولا يجوز

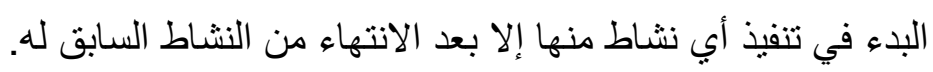

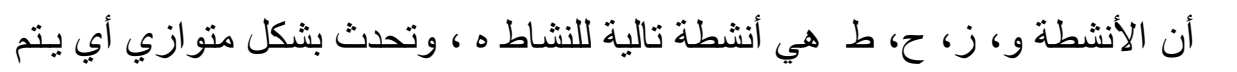

$$
\text { البدء فيها معًا وفي نفس الوقت. }
$$

• أن النشاط ي، كئ يمكن البدء فيهما في نفس الوقت على التوازي وبعد الانتهـاء مـن الأنشطة و، (ز، ط) على الترتيب، و النشاط ل هو نشاط نالي لهما.

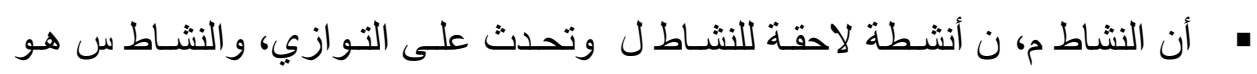
نشاط لاحق للنشاط ن. • أن النشاط ع، ف أنشطة لاحقة للنشاط س وتحدث معًا على التوازي، ويسأتي بعدها نشاط ص، ويليه نشاط ق. r- - حساب الزمن المتوسط لتنفيد الأنثطة: يمكن حسـاب التقدير ات الممكنـة لتنفيذ الأنشطة السـابقة على أسـاس المتوسط الاسط

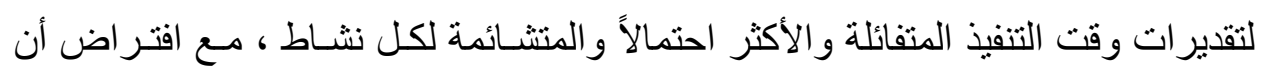
توزيعها يتماثى مع توزيع بيتا الاحتمالي من خلال المعادلات الرياضية التي تم عرضـها في الإطار الفكري لأسلوب بيرت. ويتضح ذللك على النحو التالي:

\section{جدول(0)}

الوقت المتوقع لأنشطة البرنامج التدريبي المقترح

\begin{tabular}{|c|c|c|c|c|c|c|c|}
\hline \multirow{2}{*}{ التباين } & \multirow{2}{*}{ المعياري } & \multirow{2}{*}{ المتوقع } & \multicolumn{3}{|c|}{ تقديرات وقت التنفيذ باليوم } & \multicolumn{2}{|c|}{ النشاط } \\
\hline & & & متشائم & أكثر احتمالا & متفائل & ملثاط & رمز النشاط \\
\hline 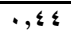 &., 77 & 10 & IV & 10 & 14 & $r=1$ & أ \\
\hline.,$\leqslant \leqslant$ & . & 10 & IV & 10 & ir & $r-r$ & ب \\
\hline ., $\leqslant$ &., 74 & 10 & IV & 10 & ir & $\varepsilon-\mu$ & ج \\
\hline
\end{tabular}

العدد الخامس والاربعون (الجزء الاول) ا Y. r.

(288)

مجلة كلية التربية- جامعة عين شمس 
د/ وفـاء عبد الفتــاح محمـود

\begin{tabular}{|c|c|c|c|c|c|c|c|}
\hline \multirow{2}{*}{ التباين } & \multirow{2}{*}{ الالمعياري } & \multirow{2}{*}{ المتوقع } & \multicolumn{3}{|c|}{ تقديرات وقت التنفيذ باليوم } & \multicolumn{2}{|c|}{ النشاط } \\
\hline & & & متشائم & أكثر احتمالا & متفائل & مدى النشاط & رمز النثاط \\
\hline., 11 & (.,rr & $\bar{r}$. & $\overline{r 1}$ & $r$ r. & rq & $0 . \varepsilon$ & د \\
\hline., 11 & $\cdot, r r$ & $r$. & $r$ & $r$. & rq & 7.0 & 0 \\
\hline$\cdot$ & . & 7. & 7. & 7. & 7. & $V-7$ & و \\
\hline$\cdot, \leqslant \leqslant$ &., 74 & 0 & $\mathrm{~V}$ & 0 & $r$ & A.7 & j \\
\hline., 11 & . & $r$ & $r$ & $r$ & 1 & $9-7$ & $\tau$ \\
\hline$\cdot, 11$ &.,$r r$ & 17 & IV & 17 & 10 & $\Lambda-9$ & b \\
\hline.,$\leqslant \leqslant$ &., 74 & 0 & $\mathrm{v}$ & 0 & $r$ & $1 \cdot-v$ & ي \\
\hline.,$\leqslant \leqslant$ & . & 0 & $\mathrm{v}$ & 0 & $r$ & $1 \cdot-1$ & ك \\
\hline$\cdot$ & $\cdot$ & $r$ & $r$ & $r$ & $r$ & $11-1$. & J \\
\hline$\cdot, \leqslant \leqslant$ &., 77 & IV & 19 & IV & 10 & $|r=1|$ & م \\
\hline,,$\leqslant \leqslant$ & . & 0 & $\mathrm{~V}$ & 0 & $r$ & $|r-1|$ & ن \\
\hline ,,$\leqslant \leqslant$ &., 74 & $\varepsilon$ & 7 & $\varepsilon$ & $r$ & $1 \leq-1 T$ & س \\
\hline • & • & $r$ & $r$ & $r$ & $r$ & $10.1 \leq$ & $\varepsilon$ \\
\hline$\cdot$ & $\cdot$ & 1 & 1 & 1 & 1 & $17-15$ & ف \\
\hline ,,$\leqslant \leq$ &., 74 & 17 & 11 & 17 & $1 \leq$ & $1 \wedge .1 V$ & ص \\
\hline ,,$\leqslant \leq$ & . & $\mathrm{V}$ & 9 & 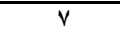 & 0 & 19.11 & ق \\
\hline
\end{tabular}

يتضـح مـن الجـدول (0) أن الـزمن الكلـي لتنفيذ البرنـامج مـع تقديم أول دورة

تدريبية لفرق التخطيط الاستر اتيجي يساوي مجموع الأزمنة المتوقعة للأنشطة = ror

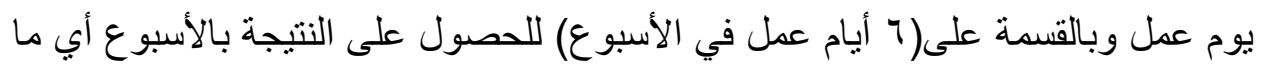
يعادل حو الي (r) أسبوع وذللك في حالة أن جميع الأنشطة تحدث في ترتيب متعاقب. وفي حالة الأنشطة المتو ازية نأخذ الأقل زمنًا فيها ويطرح من الزمن الكلي. هي ( ز، ح،

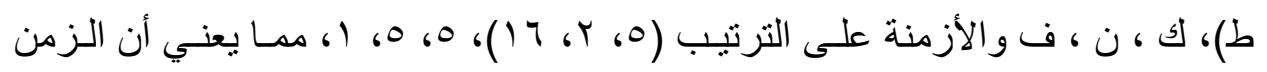
المتوفر نتيجة وجود أنشطة متوازية يساوي (§؟) يوم عمل. ويصبح الزمن الكلي المقدر

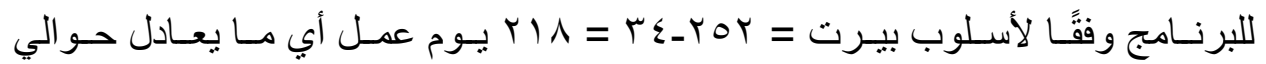




\section{استخدام أسلوب بيرت PERT في تخطيط برنامج لتدربب فرق التخطيط الاستراتيجي في الجامعات المصرية}

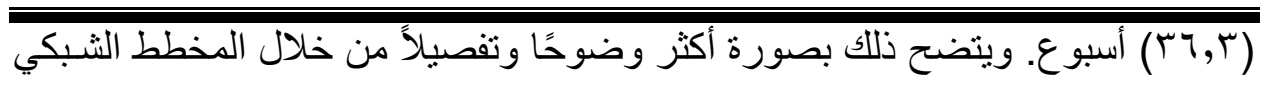
لأنشطة البرنامج التدريبي في الخطوة الثالثة و النالية. r- رسم شبكة بيرت وفقًا للأزمنة الممكنة للأنشطة:

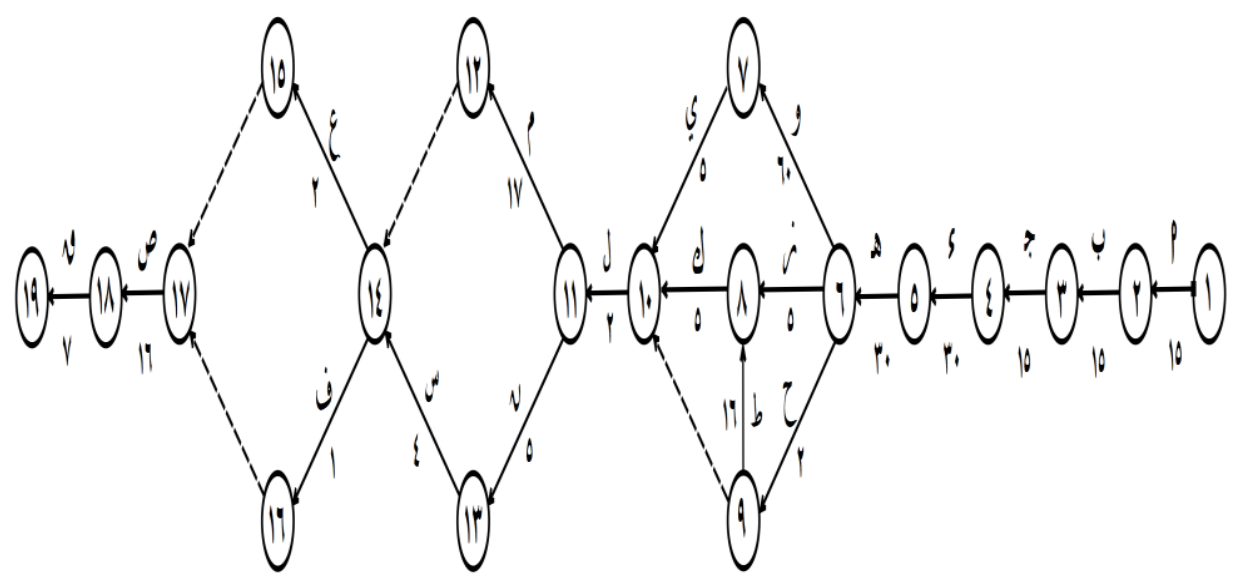

(1) (1) (1) (1) (1) (1)

المخطط الشبكي لبرنامج تدريب فرق التخطيط الاستراتيجي بالجامعات وفقًا للازمنة المتوقعة

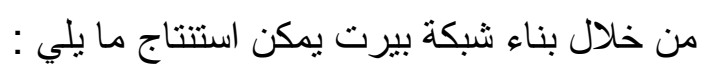

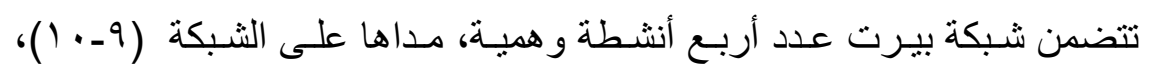
.$\left(1 V_{-} 17\right) \cdot\left(1 V_{-} 10\right) \cdot(1 \leq-1 Y)$

يمكن تحديد المسار الحرج وأنشطته من خلال تتبع الأطـو ال الزمنيـة للمسـار ات المتعددة والمختلفة على الثبكة ثم تحديد أطول مسار من حدث البدايـة إلى حدث النهايـة وهو المسار الحرج. ويتم ذلك على النحو التالي:

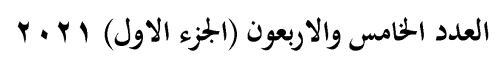

(290)

مجلة كلية التربية- جامعة عين شمس 
د/ وفـاء عبد الفتــاح محمـود

\begin{tabular}{|c|c|c|}
\hline الوقت (باليوم) & المسارات & \\
\hline YI纟 & 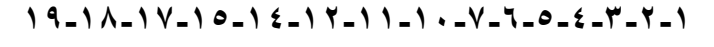 & الأول \\
\hline$r \cdot 0$ & 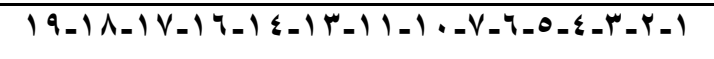 & الثاني \\
\hline 109 & 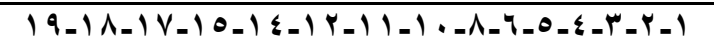 & الثالث \\
\hline 10. & 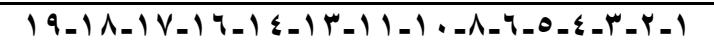 & 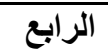 \\
\hline TVY & 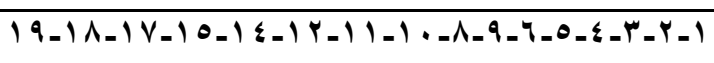 & 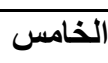 \\
\hline 174 & 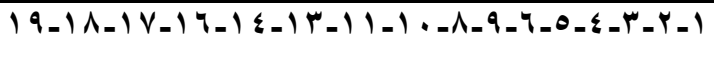 & 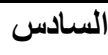 \\
\hline 101 & 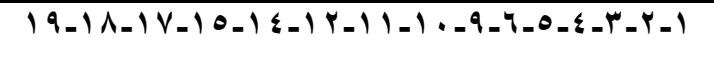 & 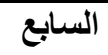 \\
\hline $1 \leqslant Y$ & 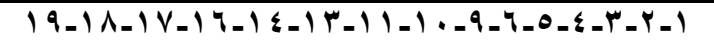 & الثامن \\
\hline
\end{tabular}

يتضح مما سبق أن عدد المسار ات الممكنة لأنشطة وخطوات البرنـامج التدريبي

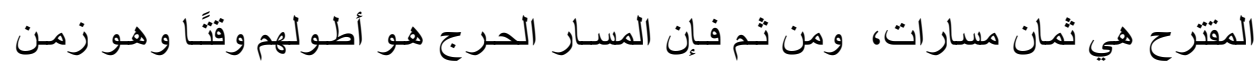

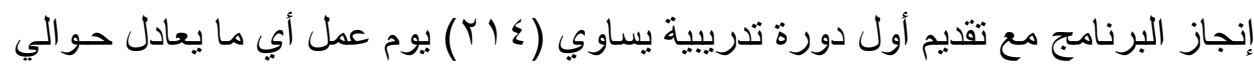

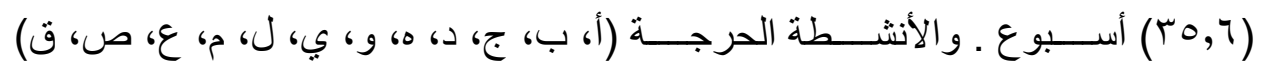
و عددها (r I ) نشاط. ع- تحديد البداية (المبكرة والمتأخرة ) والنهاية(المبكرة والمتأخرة ) لكل نشساط على

يمكن تحديد أنشطة المسار الحرج أيضًا من خلال تحديد البدايـة المبكرة و البدايـة

المتـأخرة، وكذلك النهايـة المبكرة و النهايـة المتــأخرة للأنشـة المختلفـة تميهدًا لحسـاب الوقت الفائض لكل نشاط، ويكون الزمن الفـائض لأنشطة المسـار الحرج دائمًا بسـاوي صفر. البداية المبكرة للنشـاط الأول تسـاوي صفر، النهايـة المبكرة لنشـاط مـا= البدايـة المبكرة للنشاط + مدة النشاط، و النهاية المبكرة للحدث الأخير تسـاوي النهايـة المتأخرة وبناء عليه تحسب البداية المتأخرة = النهاية المتأخرة - مدة النشاط. 
استخدام أسلوب بيرت PERT في تخطيط برنامج لتدريب فرق التخطيط الاستراتيجي في الجامعات المصرية فيطاية

\section{جدول(7)}

أزمنة البداية والنهاية والوقت الفائض لأنشطة البرنامج التدريبي

\begin{tabular}{|c|c|c|c|c|c|c|c|c|}
\hline المرجار & السماح| الزمائ & المتأخرة النهة & المتأخراية & المبكرة النهاية & المبكرة البية & الزمتمن & النشاط & رالثزاط \\
\hline * & . & 10 & . & 10 & . & 10 & $r=1$ & أ \\
\hline * & . & r. & 10 & $r$. & 10 & 10 & $r-r$ & ب ب \\
\hline * & . & $\varepsilon 0$ & r. & $\varepsilon 0$ & r. & 10 & $\varepsilon-r$ & ج \\
\hline * & . & Vo & $\leqslant 0$ & Vo & $\leqslant 0$ & $r$. & $0 . \varepsilon$ & 1 \\
\hline * & • & 1.0 & Vo & 1.0 & Vo & r. & 7.0 & 0 \\
\hline \multirow[t]{4}{*}{ * } & . & 170 & 1.0 & 170 & 1.0 & 7. & $V-7$ & 9 \\
\hline & $\varepsilon \varepsilon$ & $10 \varepsilon$ & $1 \leq 9$ & 11. & 1.0 & 0 & A.7 & j \\
\hline & $7 r$ & 18. & 171 & $1 . V$ & 1.0 & $r$ & 9.7 & $\tau$ \\
\hline & $\varepsilon V$ & $1 \mathrm{Ve}$ & $10 \leq$ & Ir & $1 . V$ & 17 & 1.9 & $b$ \\
\hline \multirow[t]{3}{*}{ * } & . & 18. & 170 & 18. & 170 & 0 & $1 \cdot-V$ & ي \\
\hline & $\varepsilon r$ & 18. & 170 & $1 Y \Lambda$ & IYr & 0 & $1 \cdot-1$ & ك5 \\
\hline & $7 r$ & 18. & $1 \mathrm{~V}$. & $1 \cdot v$ & $1 . v$ & $\cdot$ & $1 .-9$ & وهمي \\
\hline * & . & IVY & IV. & IVY & 18. & $r$ & $\begin{array}{c}-1 \\
11\end{array}$ & J \\
\hline \multirow[t]{2}{*}{ * } & . & $1 \wedge 9$ & IVY & $1 \wedge 9$ & IVY & 18 & $\begin{array}{c}-11 \\
14\end{array}$ & p \\
\hline & $\Lambda$ & $1 \wedge 0$ & $1 \wedge$. & IVV & IVY & 0 & $\begin{array}{c}-11 \\
11\end{array}$ & ن \\
\hline \multirow[t]{2}{*}{ * } & . & $1 \wedge 9$ & $1 \wedge 9$ & $1 \wedge 9$ & $1 \wedge 9$ & . & $\begin{array}{c}-14 \\
1 \varepsilon\end{array}$ & وهمي \\
\hline & $\Lambda$ & 119 & $1 \wedge 0$ & $1 \wedge 1$ & $I V V$ & $\varepsilon$ & $\begin{array}{c}-14 \\
1 \varepsilon\end{array}$ & س \\
\hline \multirow[t]{2}{*}{ * } & . & 191 & $1 \wedge 9$ & 191 & 119 & $Y$ & $\begin{array}{c}-18 \\
10\end{array}$ & $\varepsilon$ \\
\hline & 1 & 191 & 19. & 19. & 119 & 1 & $\begin{array}{r}-18 \\
17\end{array}$ & ف \\
\hline \multirow[t]{2}{*}{ * } & . & 191 & 191 & 191 & 191 & . & $\begin{array}{l}-10 \\
18\end{array}$ & وهمي \\
\hline & 1 & 191 & 191 & 19. & 19. & . & $\begin{array}{r}-17 \\
18\end{array}$ & وهمي \\
\hline * & . & $r \cdot V$ & 191 & $r \cdot V$ & 191 & 17 & $\begin{array}{c}-18 \\
11\end{array}$ & ص \\
\hline * & . & YIs & $r \cdot V$ & YIs & $r \cdot V$ & V & $\begin{array}{c}-11 \\
19\end{array}$ & ق \\
\hline
\end{tabular}

العدد الخامس والاربعون (الجزء الاول) Y.Y. T.

(292)

مجلة كلية التربية- جامعة عين شمس 
يتضح من الجدول (7) أن معظم أنشطة و عمليات البرنامج التدريبي المقترح هي

أنشطة حرجة ذات وقت فائض بساوي صـفر، ممـا يعنـي انعـدام فرصـة تـأخير تتفيـها، و الأنشطة الحرجة التي ليس لهـا سـماح عددها (Y I) نشـاط، وهـي (أ، ب، ج، د، ه، و، ي، ل، م، ع، ص، ق). أما الأنشطة غير الحرجة والتي لها وقت فـائض بيسمح بتأخير تتفيذها في حدوده عددها (V) نشـاط، وهي (ز،ح، ط، لك، ن، س، ف) و الوقت الفـائض

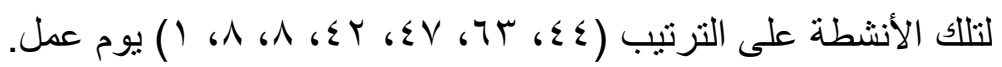
هـ رسم شبكة بيرت للبرنامج التدريبي موضح عليها المسار الحرج: يتضــح مسن المخطـط الشـبكي التـالي البـدايات المبكـرة والمتــأخرة وكذلك النهايـات المبكرة و المتـأخرة لكل نشـاط على حـده والمسـار الحـرج وزمسن إنجـاز

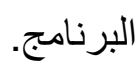

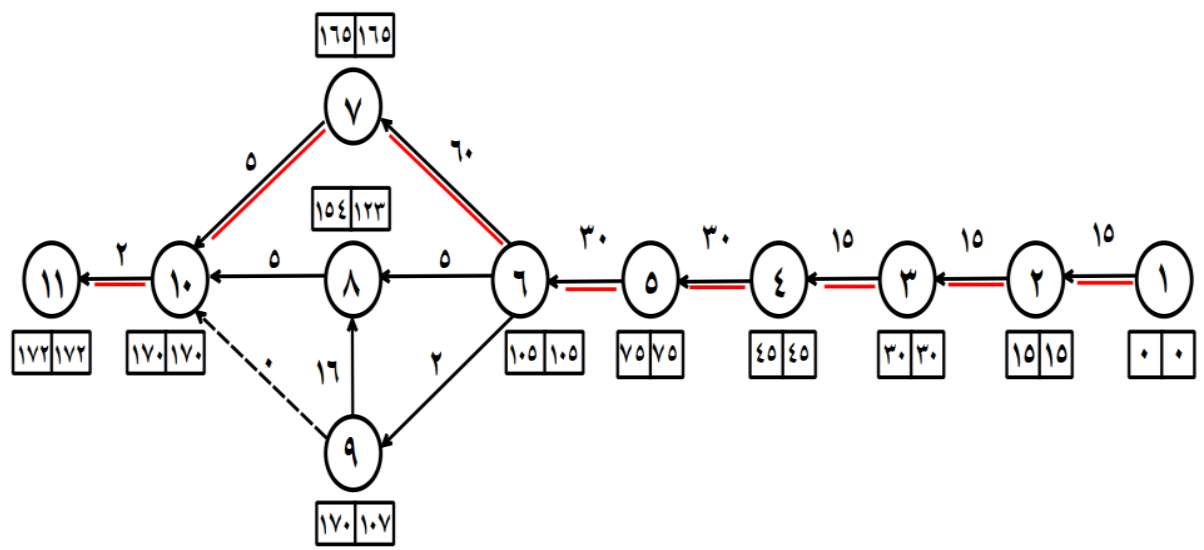


استخام أسلوب بيرت PERT في تخطيط برنامج لتتريب فرق التخطيط الاستراتيجي في الجامعات المصرية

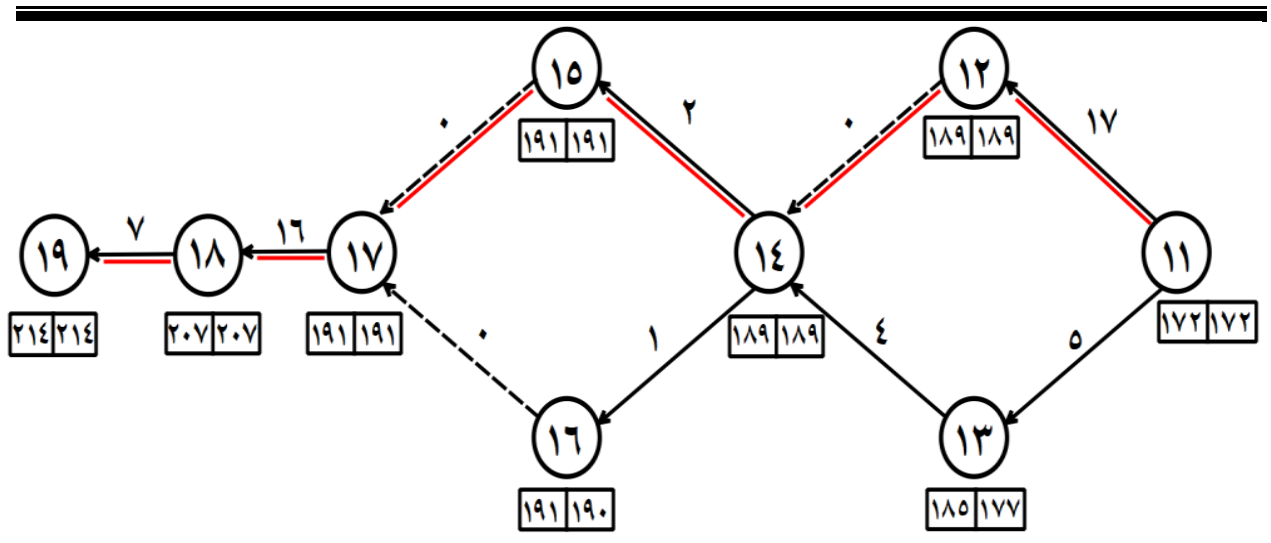

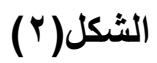

المخطط الثبكي للبرنامج التدريبي موضح عليه المسار الحرج

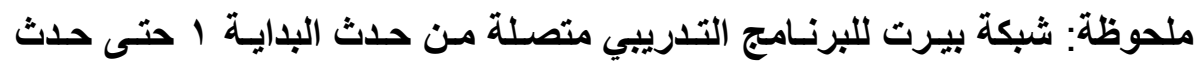

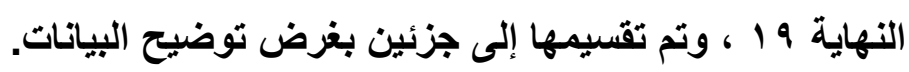

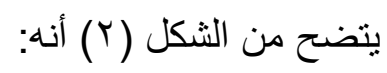
في حالـة الحسابات الأمامية على الثبكة: عند حسـاب الأوقات المبكرة للبدء و الانتهاء للنشاط يكون حدث البداية ( تكون البداية المبكرة تساوي صفر (التو و اللحظة)، و عندما يوجد أكثر من نهاية مبكرة للحدث فإنه يتم اختيـار النهايـة المبكرة الأكبر زمنًا.

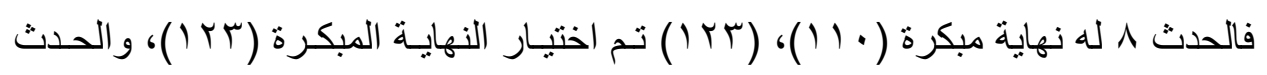

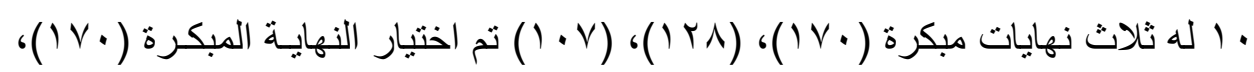

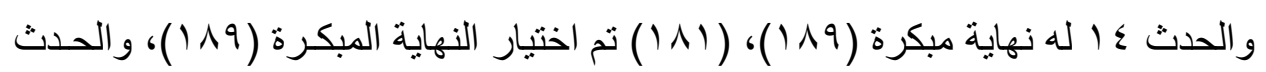

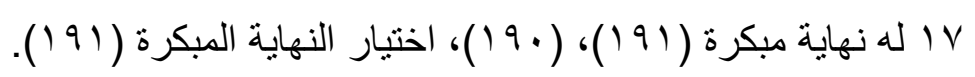

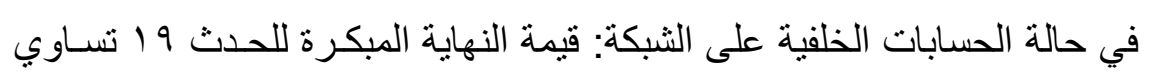

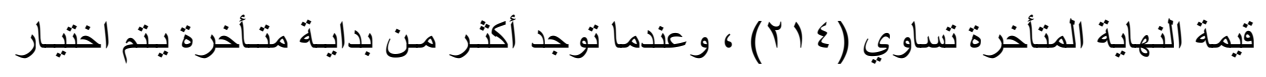

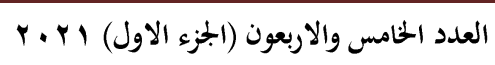
(294) مجلة كلية التربية- جامعة عين شمس 


\section{د/ وفـاء عبد الفتــاح محمـود}

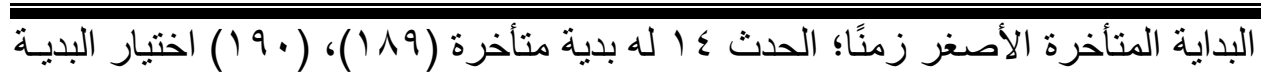

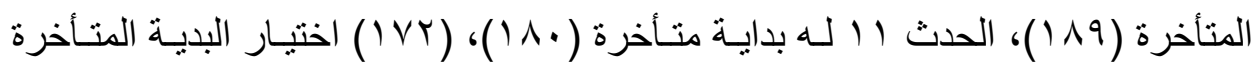

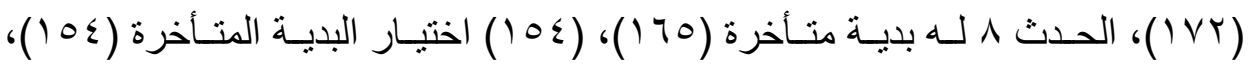
الحدث 7 له بدية متأخرة (1) ( )، (9 ع ( )، (0. (1) اختيار البدية المتأخرة (0. ( ).

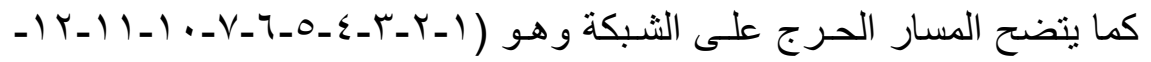

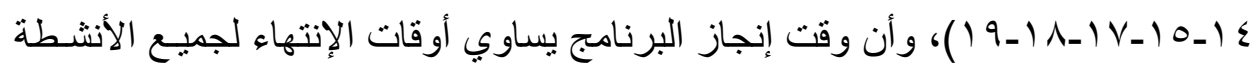
يساوي وقت المسار الحرج يساوي (؟ اY) يوم عمل.

7- تحديد احتمالية تثفيذ البرنامج: لما كانت تقدير ات وقت تتفيذ أنشطة البرنامج التدريبي تتفـاوت في نطـاق معين فإنه يمكن توقع عدد من الاحتمـالات المختلفـة لوقت تتفيذ البرنـامج التدريبي عند فترة زمنية محددة أقل أو أكثر من المدة الزمنية المقدرة ، مع العلم - من خـلال بيانـات الثـكل

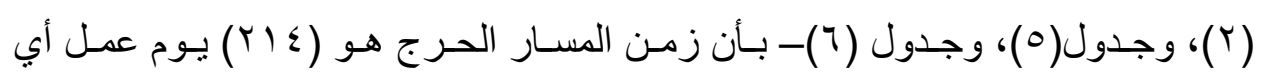

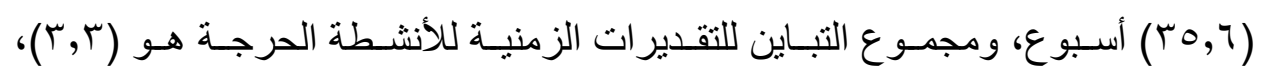
وبتطبيق معادلة القيمة المعياريـة التـي تم عرضـها في الإطـار الفكري لأسـلوب بيـرت يتضح ما بلي:

جدول)

احثمالية تنفيذ البرنامج

\begin{tabular}{|c|c|c|c|c|c|c|c|}
\hline$r q$ & $r q, r$ & $r v$ & $\mu \Lambda$ & rq & $\varepsilon$ & $\$ 1$ & الزمن المقدر \\
\hline$\cdot, r r$ & $\cdot, r q$ & $\cdot, \mathrm{VV}$ & $1, r r$ & $1, \wedge V$ & $r, \leqslant r$ & $r, q V$ & القيمة المعيارية \\
\hline $71, r$ & 71,7 & VY, & $q \cdot, r$ & $97, V$ & $99, r$ & 99,1 & احتمالية إنهاء البرنـامج \\
\hline
\end{tabular}

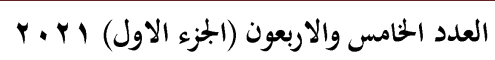

(295)

مجلة كلية التربية- جامعة عين شمس 
استخلام أسلوب بيرت PERT في تخطيط برنامج لتدريب فرق التخطيط الاستراتيجي في الجامعات المصرية

تم تحديد نسبة احتمـال إنهاء البرنـامج مـن جدول التوزيع الطبيعي أي الجدول

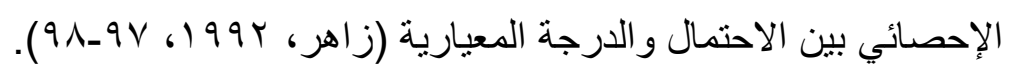

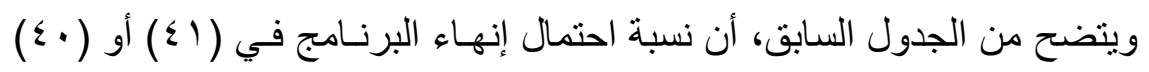

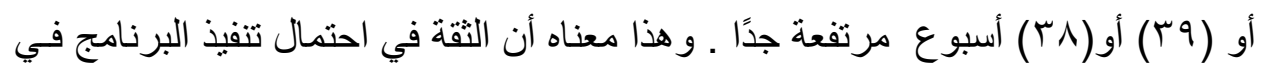

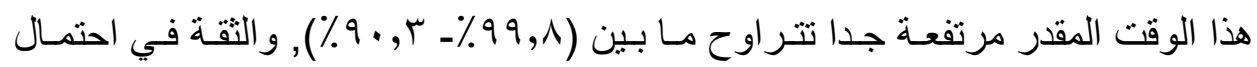

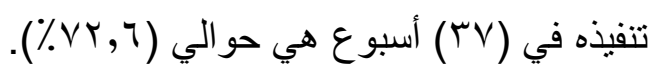
نتائج البحث وتوصياته: تتمثل أهم النتائج التي توصل إليها البحث فيما يلي : العدد المناسب لفريق التخطيط الاسـتر اتيجي يتر اوح بين (9 ـ (1) بحيث بضـم بين

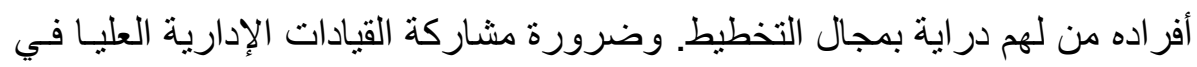
عملية التخطيط. تمثلت فرق التخطبط الاسـتر اتيجي للجامعـات في فريـق التخطبط المركزي على مستوى الجامعة وفريق متابعة الخطط التنفيذيـة للخطـة الاستر اتيجية للجامعـة وفريق

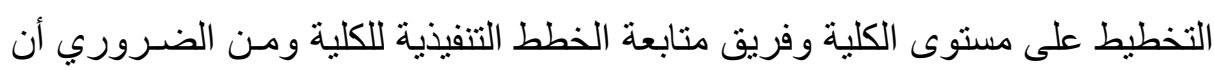
يضم فريق المتابعة بالجامعة أو الكلية بين أعضاءه الفريق القائم بالتخطبط بأكمله.

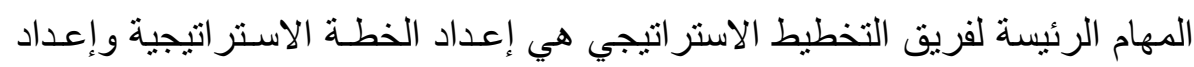
الخطط التتفيذية للخطة الاستر اتيجية ومتابعة تنفيذها وتقويمها. تنوعت الكفايات اللازمة للفريق القائم بالتخطيط الاستر اتيجي بالجامعة وكلياتها ومن أهمها: الكفايات التخطيطية والبحثية و الإحصائية و الإدارية و التكنولوجية والثخصية و الإنسانية. تتحـدد عمليـة سـير التـدريب في تحديـد الاحتياجـات التدريييـة، تخطيط إجـراءات التدريب، تتفيذ التدريب، متابعة وتقويم التدريب. 


\section{د/ وفـاء عبد الفتــاح محمـود}

تتمثل عناصر أى خطة تدريبية في أهداف البرنـامج التدريبي، المحتوى التدريبي، وسائل التدريب، أساليب التدريب، اختيار المدربين، اختيار المتدربين، زمـان ومكان التدريب، التكاليف المباثرة وغير المباشرة للتدريب. تتمثل أهداف برنامج تدريب فريق التخطيط الاستر اتيجي في تتمية وتطوير الكفايـات التخطيطية الفنية المتعلقة بالتحليل البيئى وصـياغة رسـالة ورؤيـة المؤسسـة وتحديـد الغايات و الأهداف الاستر اتيجية، ترجمة الخطـة الاسـتر اتيجية إلى الخطط التفيذيـة، متابعة وتقويم الخطة الاستر اتيجية و إعداد الخطة الجديدة. أن الوقت الكلي المقدر لتنفيذ أنشطة البرنامج التدريبي ومـع تقديم أول دورة تدريبيـة لفرق التخطيط الاستر اتيجي باستخدام أسلوب بيرت هو (YOY) يوم عمل أي حـوالي ( ) أسبوع، ويتم توفير (؟Y) يوم نتيجة وجود أنشطة متوازية تحدث معاً في نفس

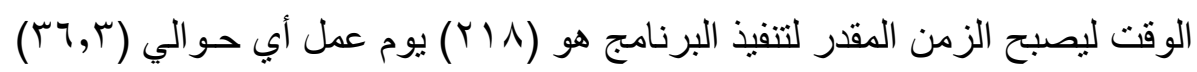

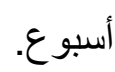

عـد المسـار ات الممكنـة لأنشـطة البرنـامج التـدريبي على المخطـط الثـبكي ثمـان

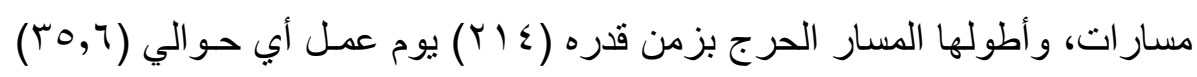
أسبوع وهو زمن إنجاز البرنامج التدريبي مع تقديم أول دورة تدريبية. لا يوجد أكثر من مسار حرج على المخطط الثبكي لبرنـامج تدريب فرق التخطيط

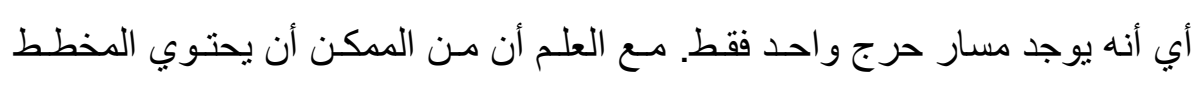
الثبكي لأى من البـرامج أو المشـروعات على أكثر مـن مسـار حـرج ويـتم اختبـار أكبر هم زمنًا ليكون الزمن اللازم لإنجاز البرنامج أو المشروع. احتمالية تتفيذ البرنامج المقترح في فترة ( ع_مب) أسبوع تكون مرتفعـة للغايـة ممـا يعني أن الثقة في إحتمالية تنفيذ البرنامج التدريبي في هذا الوقت المتوقع مرتفعـة

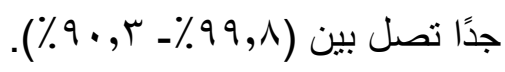




\section{استخدام أسلوب بيرت PERT في تخطيط برنامج لتدربب فرق التخطيط الاستراتيجي في الجامعات المصرية}

الأنشطة الحرجة التي تحتاج إلى عناية و انتباه خـاص مـن إدارة البرنـامج و لا يسـح

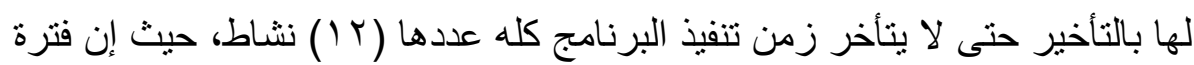
السماح لتلك الأنشطة تساوي صفر، وهي على الترتيب: (أ، ب، ج، د، ه، و، ي، ل، م، ع، صن، ق) (ال)

الأنشطة غير الحرجـة عددها (V) نشـاط ويسـمح بالتـأخير فيهـا في حدود الوقت الفائض، وهي على الترتيب: (ز) إعداد ملفـات التقويم، (ح) حصـر المركز عدد أعضاء وحدات التخطيط الاستر اتيجي بالجامعة وكلياتها، (ط) إعداد المركز قائمـة بأسماء الأساتذة ذوى الخبرة في مجال التخطيط عامة و التخطيط الاستر اتيجي خاصة وتحديد أماكن عملهم من داخل وخارج الجامعـة، (ك) إعداد ميز انيـة التدريب، (ن) اختيار ومخاطبة المدربين، (س) استلام خطة الجلسة التدرييـة مـن كل مدرب قبـل تنفيذ التدريب بوقت مناسب، (ف) إعداد قاعة التدريب. وفترة السماح لتلك الأنشطة

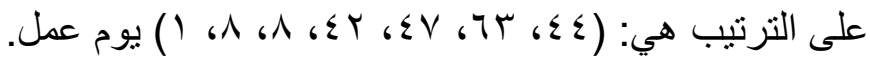
يوضـح أسـلوب بيـرت علاقـات التتـابع المنطقي بـين الأنشــة المكونــة للبرنــامج التدريبي، ويعطي تصور بياني يـوفر بيانـات ومعلومـات دقيقة عن البدايـة المبكرة و المتأخرة وكذلك النهاية المبكرة و المتأخرة لكل نشاط. يسـاعد أسـلوب بيـرت إدارة البرنـامج التـدريبي على التعرف على على مـا يجب عملـه لإنجاز أهداف البرنامج في الوقت المحدد. يساعد أسلوب بيرت في محاولة تسريع الزمن اللازم لتنفيذ بعض أو كل الأنشطة مع

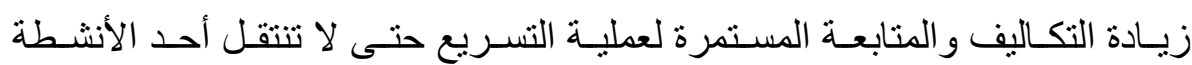
الحرجة إلى أنشطة غير حرجة، وذلك لضمان تنفيذ البرنامج في أقصر وقت ممكن. 


\section{يوصى البحث الحالي بما يلي:}

ضرورة تبني متخذب القرار في الجامعـات المصـرية للبرنـامج التدريبي المقترح:

تطوير الكفايات التخطيطية لدى فرق التخطيط الاستر اتيجي بالجامعات المصرية. ضرورة اهتمام الجامعات بإنشاء مر اكز تأهيل مخططي التعليم ملحقة بكليات التربيـة

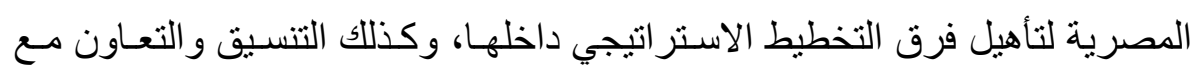

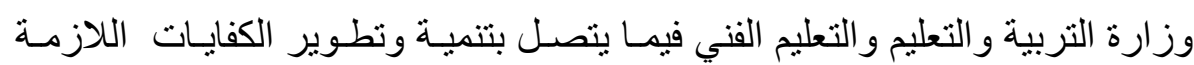
لمخططي التعليم داخل الوزارة والمديريات و الأدارات التعليمية. قيام الوحدات المركزية للتخطيط الاستر اتيجي بالجامعات بدور ها في توعية القيـادات الإدارية العليا بالكليات بأهمية تدريب فريق وحدات التخطيط الاستر اتيجي، وتحفيز

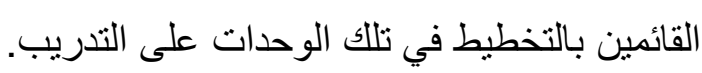

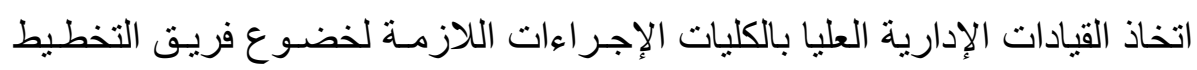

$$
\text { الاستر اتيجي إلى البرنامج التدريبي دون أي أعذار. }
$$

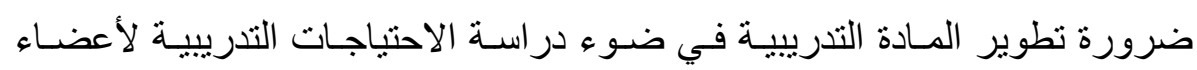
وحدات التخطيط الاستر اتيجي بين الحين و الآخر بمـا يسـاعد على تطوير معـارفهر

$$
\text { ومهار اتهم في مجال التخطيط الاستر اتيجي. }
$$

ضرورة توفير مدربين بالكم والكيف المطلوبين سواء من داخل أو خـارج الجامعـة، بحيث يكون المدرب على دراية بالجانب النظري في مجال التخطيط التربوي ولديـه خبرة عملية في المجال وبالتالي ينجح في تنمية كفايـات التخطيط الاستر اتيجي التي يحتاجها المتدربون.

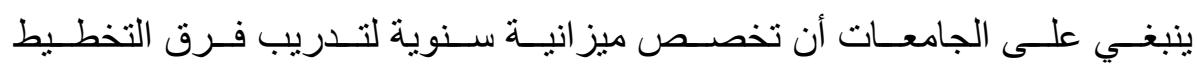
الاسـتراتيجي لتنميـة وتطـوير الكفايـات التخطيطيـة لـديهم. وضـرورة البحـث عـن مصادر إضافية مستدامة لتمويل الدورات التدريبية. 


\section{استخدام أسلوب بيرت PERT في تخطيط برنامج لتدريب فرق التخطيط الاستراتيجي في الجامعات المصرية}

" أن تخصص كل جامعة جائزة سنوية لأفضل وحدة تخطيط على مستوى الكليات بعد

أن تضع معايير للتنافس.

ضرورة إنشاء قاعدة بيانـات ومعلومـات بوحدات التخطيط الاسـتر اتيجي المركزيـة بالجامعات توفر كل الدعم المعلوماتي للكليات فيما يخص إعداد الخطة الاستر اتيجية. ضـروة تـدريب فريـق التخطيط الاسـتر اتيجي على اسـتخدام الوســئل التكنولوجيـة الحديثة التي تزيد من فعالية العملية التخطيطية. جعل امتلاك كفايات التخطيط الاستر اتيجي عن طريق الدورات التدريبيـة شـرط من شـروط الترقي لمناصـب القبـادات الإداريـة الأكاديميـة في الجامعــات الحكوميـة المصرية، باعتبار هم يمثلون فريق عمل في عملية التخطيط الاستراتيجي. ضرورة إضافة وحدة تدريبية (إجبارية) عن مفاهيم التخطيط الاستر اتيجي ومر احله ضمن الدورات التدرييـة لمركز تنميـة قدرات إعضــاء هيئـة التـدريس بالجامعـات،

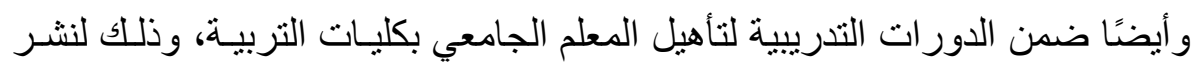
ثقافة التخطيط الاستر اتيجي لدى جميع أعضاء هيئسة التدريس بالجامعـات، وباعتبـار أن عدد منهم يمثلون في فرق العمل في عملية التخطيط الاستراتيجي. ضرورة استخدام الأساليب العلمية في تخطيط ومتابعة إنجاز البرامج التدريبيـة التي لتي

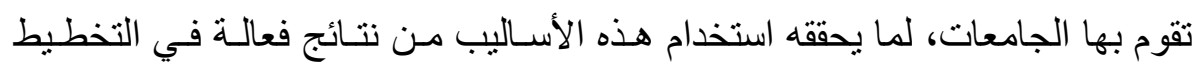
للوقت و التكلفة. ضرورة الاهتمام بتوفير المستلزمات المادية للبرنامج بالأوقات المناسبة وبالكميـات المطلوبة إذ إن التاخير في الحصول عليها يؤدي إلى التوقف عن العمل وهذا يعنـي تأخر إتمام البرنامج في الوقت المحدد. 


\section{المراجع}

أولاً: المراجع العربية: أن

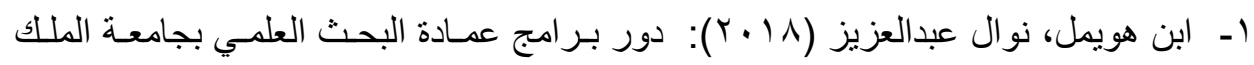
سعود في تنمية المهار ات البحثية لدى الطالبـات، مجلـة العلـوم التربويـة والنفسية، المركز القومي للبحوث غزة، المجلد الثاني، العدد الرابع، فبر اير.

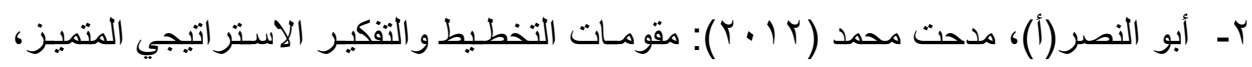
المجمو عة العربية للتدريب و النشر، القاهرة.

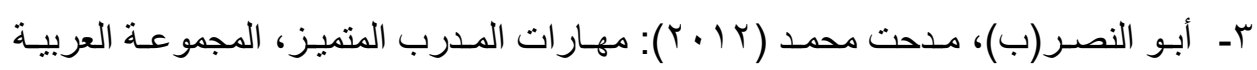
للتدريب و النشر ، القاهرة.

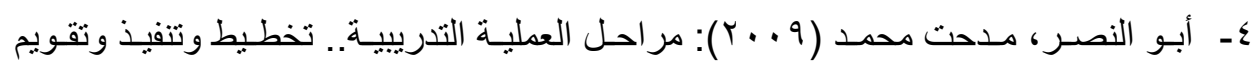
البرامج التدريبية، المجمو عة العربية للتدريب و النشر، القاهرة.

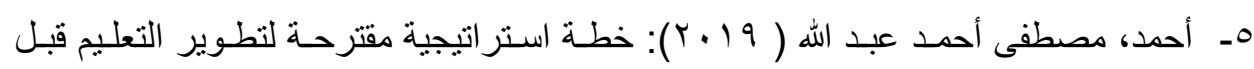
الجامعي بمصر في ضوء نموذج فـايفر(Pfeiffer) ، رسـالة دكتور اه، كليـة التربيـة بقنـا، جامعة جنوب الو ادي.

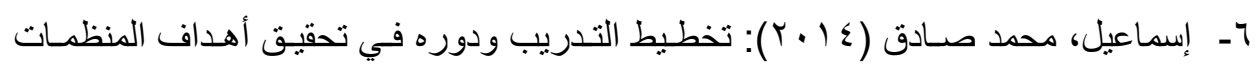
العامة والخاصة، المجمو عة العربية للتدريب و النشر، القاهرة.

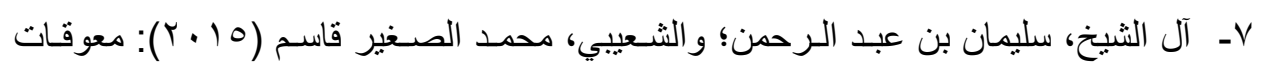
التخطبط الاستر اتيجي في الجامعات السعودية، مجلة جامعة الملك عبد العزيز "الاقتصساد والإدارة"، جامعة الملك عبد العزيز، المجلد (و ب)، العدد الثاني.

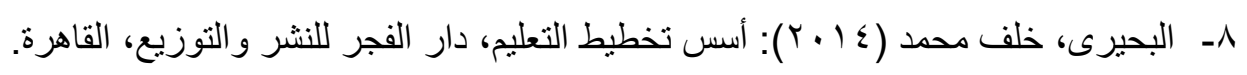
9- بر ايسون، جون م. (r . r): التخطيط الاستر اتيجي للمؤسسات العامة و غير الربحية.. دليل عمل لاعم الإنجاز المؤسسي واستدامته، ترجمة: محمد عزت عبد الموجـود، مكتبـة لبنـان ناشرون، لبنان. • ـ البلوي، نور بنـت صـالح بـن مسيب؛ والسـود، راتب سـلامة (0 10 • ب): برنـامج تدريبي مقترح لتطـوير الكفايـات الفنبـة لمـديري مـدارس مشـروع الملك عبد الله بـن عبد العزيـز

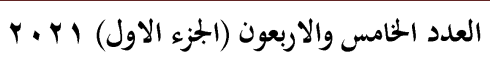

$$
\begin{aligned}
& \text { (301) } \\
& \text { مجلة كلية التربية- جامعة عين شمس }
\end{aligned}
$$




\section{استخدام أسلوب بيرت PERT في تخطيط برنامج لتدريب فرق التخطيط الاستراتيجي في الجامعات المصرية}

لتطوير التعليم في المملكة العربية السعودية، رسالة دكتور اه، كلية الدراسات العليا، الجامعة الأردنية.

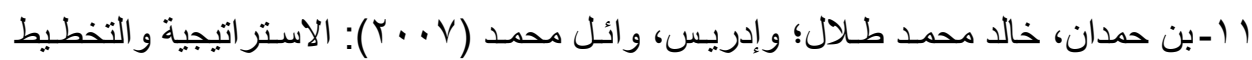
الاستر اتيجي.. منهج معاصر، دار اليازوري العلمية، عمان.

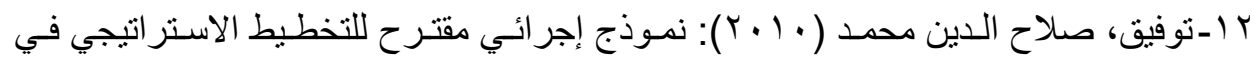

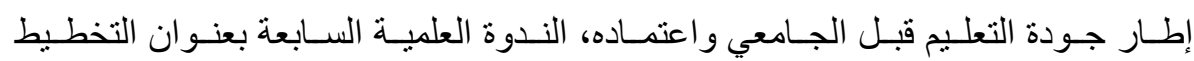

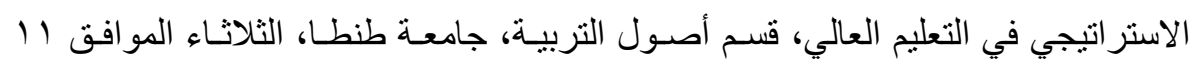
مايو. r ا - جادالرب، سيد محمد (7 ( • ץ): التخطيط الاستر اتيجي منهج لتحقيق التميز التنافسى، دار الفجر للنشر و التوزيع، القاهرة.

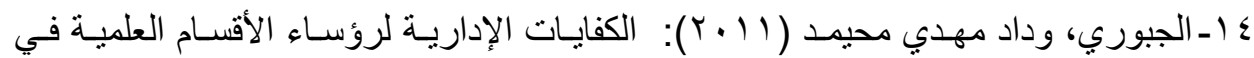

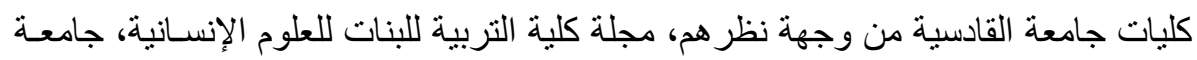
الكوفة، المجلد الخامس، العدد الثامن.

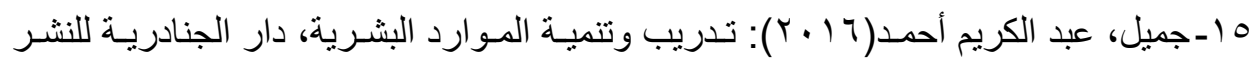
و التوزيع، عمان، الأردن.

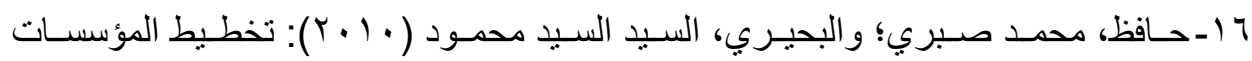
التعليمية، الطبعة الثانية، عالم الكتب، القاهرة.

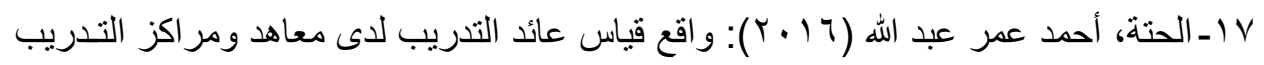

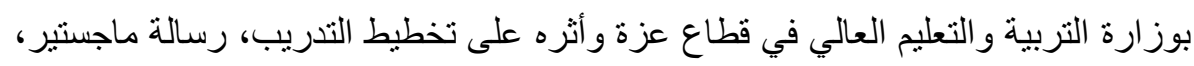
كلية التجارة، الجامعة الإسلامية بغزة.

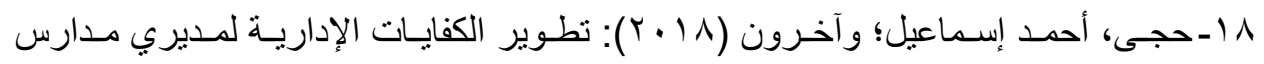

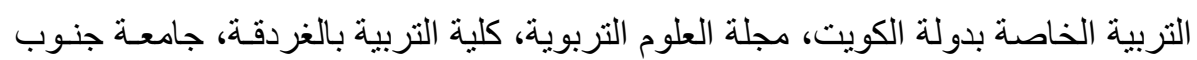
الو ادي، العدد الثاني، ديسمبر. 


\section{د/ وفـاء عبد الفتــاح محمـود}

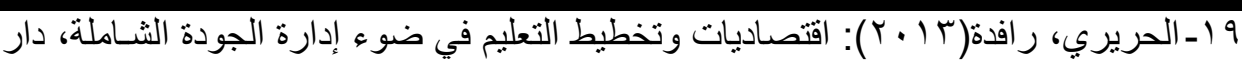

المناهج للنشر و التوزيع، عمان، الأردن.

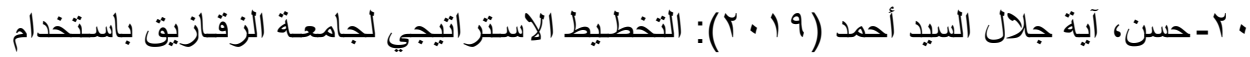

بطاقة الأداء المنوازن، رسالة ماجستير، كلية التربية، جامعة الزقازيق.

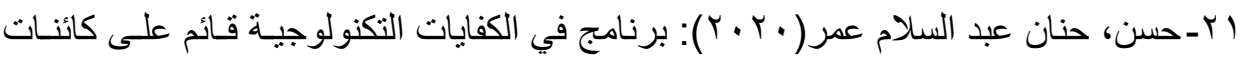
التعلم الرقمية لتنمية مهار ات إنتاجها و استخدامها في تدريس الجغر افيـا لدي طـلاب الدبلوم العام، المجلة التربوية، كلية التربية، جامعة سوهاج، العدد(VV)، سبتمبر.

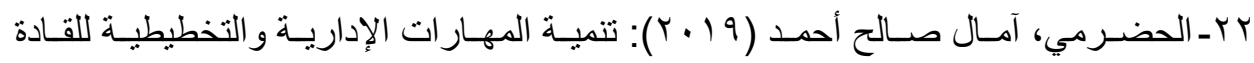
التربـويين في وزارة التربيـة والتعليم بالجمهوريـة اليمنيـة، رسـالة دكتـور اه، كليـة العلـوم الإنسانية و الاجتماعية، تونس. بr الحلاق، دينا يوسف عبد الرحمن؛ و آخـرون (10 • (Y): خبرات بعض الـدول في مجـال تدريب القيادات لتنمية كفايـات التخطيط الاسـتر اتيجي و إمكانيـة الإفـادة منهـا في فلسطين، مجلة البحث العلمي في التربية، كلية البنات للآداب و العلوم و التربيـة، جامعـة عين شـمس، العدد(T ا ( )، الجزء الثناني.

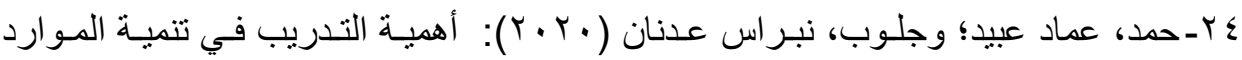
البشرية.. الأسـاليب و الوسائل.. در اسـة نظريـة تحليليـة، مجلـة الآداب، كليـة الآداب، جامعـة

بغداد، المجلد الرابع/ ملحق، العدد (ع با ).

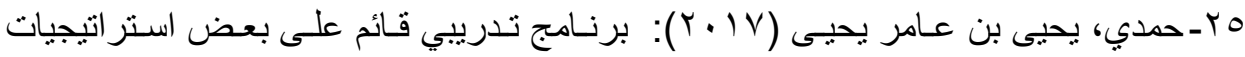
التعلم النشط لتطوير الأداء التدريسي لمعلمهي الرياضـيات بالمرحلـة الابتدائيـة، مجلـة كليـة

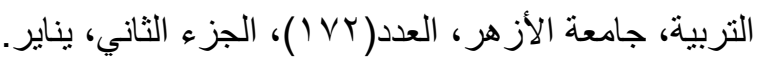

جبـ الحـوت، محمـد صسبري (990 (1)): بعض أسـاليب تقـويم الخطط و البـر امج و المشـرو عات التعليميـة... المفهـوم والإجـر اءات و القيـود، مجلـة التربيـة و التنميـة، المكتـب الاستشــاري للخدمات التربوية بالقاهرة، السنة الثالثة، العدد الثامن، فبر اير. 


\section{استخدام أسلوب بيرت PERT في تخطيط برنامج لتدربب فرق التخطيط الاستراتيجي في الجامعات المصرية}

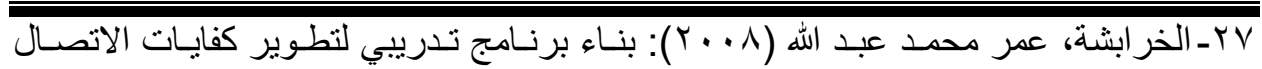

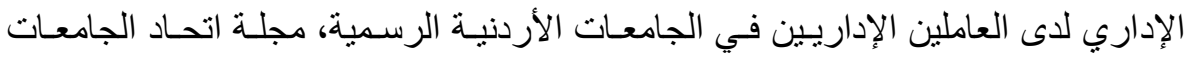
العربية للتربية وعلم النفس، كليه التربية، جامعه دمثق، المجلد الساد،، العدد الأول.

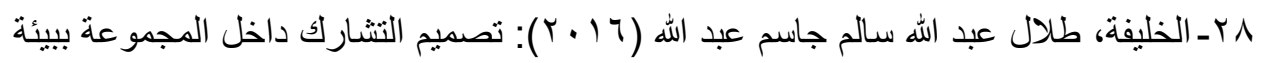

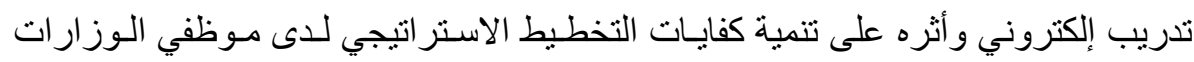
بالكويت، رسالة ماجستير، كلية الدراسات العليا، جامعة الخليج العربي بالبحرين.

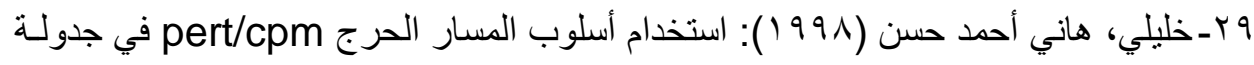

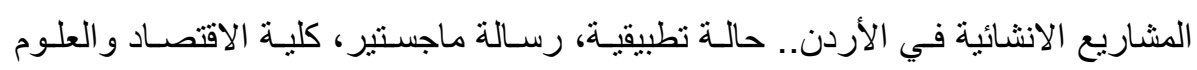
الإدارية، جامعة اليرموك، الأردن.

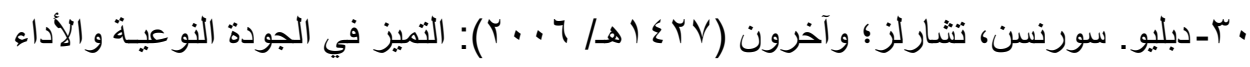

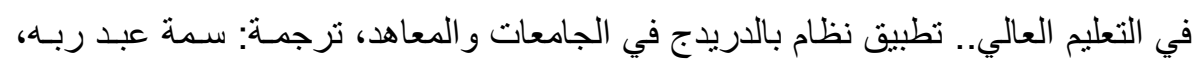
مكتبة العكبيان، الرياض.

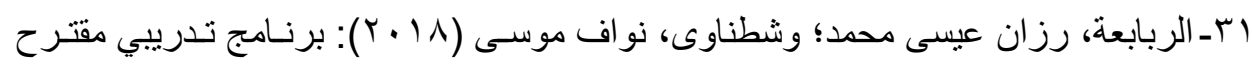
لتطوير الكفايات الإدارية لمديري المدارس الحكومية في لواء قصبة اربد، رسالة دكتور اه، كلية التربية، جامعة اليرموك، الأردن.

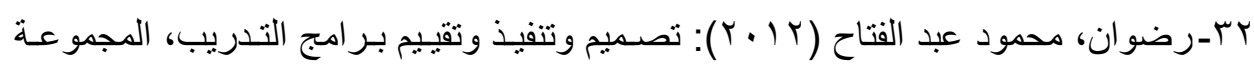
العربية للتنريب و النشر ، القاهرة. بس-ز اهـر، ضـياء الدين( (99 ()): تـدريب الكوادر الإداريـة والتدريبيـة لتعليم الكبـار.. إطـار

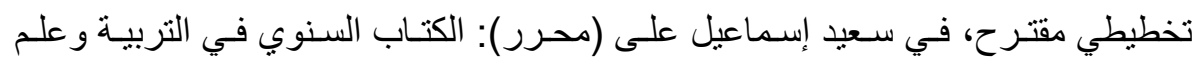
النفس.. دراسات في اقتصاديات التعليم وتخطيطة، دار الفكر العربي، القاهرة.

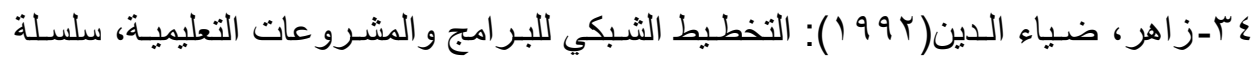
در اسات في التربية(r)، مركز ابن خلدون للدر اسات الإنمائية، القاهرة.

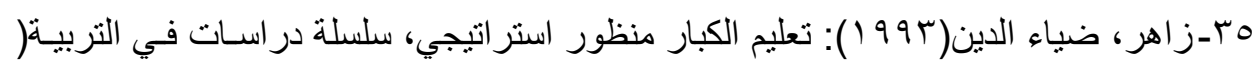
9)، مركز ابن خلدون للار اسات الإنمائية، القاهرة.

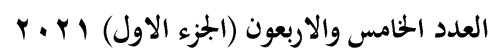

(304)
مجلة كلية التربية- جامعة عين شمس 


\section{د/ وفـاء عبد القتــاح محمـود}

بس-ز اهر، محمد ضياء الدين عبد الشكور (1911 ): تصميم وتخطيط مشـروع كليـة للار اسـات العليا بجامعة عين شمس باستخدام أسلوب بيرت P.E.R.T. و الكمبيونر ، رسالة دكتور اه، كلية التربية، جامعة عين شمس.

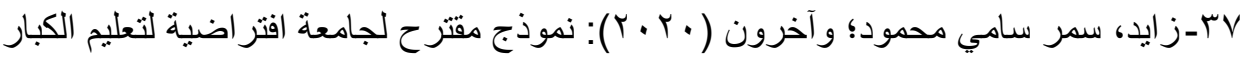
باستخدام أسلوب بيـرت، مجلـة البحث العلمي في التربيـة، كليـة البنـات لـلآداب و العلـوم و التربية، جامعة عين شمس، العدد ( (Y)، عدد خاص.

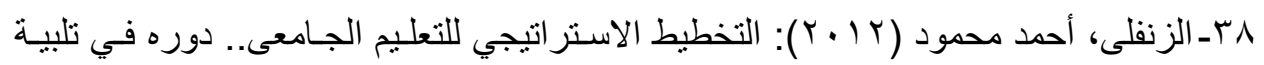
منلطبات التنمية المستدامة، سلسلة التربية والمستقبل العربي (ب)، مكتبة الأنجلو المصـرية، القاهرة. و بـ السبيعي، خالد بن صالح المرزم (1 ( • ب): جدولة المشاريع البحثية لطلبة الدراسـات العليـا التربوية بجامعة الملك سعود باسـتخدام أسـلوب بيـرت و المسـار الحرج... در اسـة تطبيقيـة، مجلة كلية التربية في العلوم التربوية، كلية التربية، جامعة عين شمس، العدد(بـ)، الجزءء الثالث. • ع- ستوت، دلال بدر الدين (T ( • ؟): استخدام شبكات بيـرت في تخفيض التكـاليف.. در اسـة تطبيقية، رسالة ماجستير، كلية الاقتصاد، جامعة حلب.

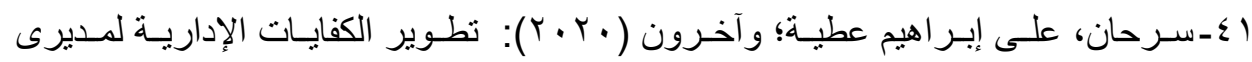
مدارس التعليم الأساسي في مصر، مجلة كلية التربية، جامعـة كفر الثـيخ، المجلد الثـاني،

$$
\text { العدد الثاني. }
$$

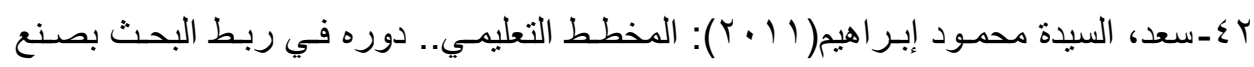
السياسة التعليمية، سلسلة التربية و المستقبل العربي ( (1)، مكتبة الأنجلو المصرية، القاهرة. بـ ـ سليمان، سعيد أحمد( (99 (1)): نموذج مقتر ح لتخطيط بر امج تدريب المعلمين أثنـاء الخدمسة، في سعيد إسماعيل على (محرر): الكتاب السنوي في التربيـة وعلم النفس.. در اسـات في اقتصاديات التعليم وتخطيطة، دار الفكر العربي، القاهرة. ع ـ السيد، ناديـة حسـن (ب9 (99 ) ): التخطبط لبعض بـر امج كليـات التربيـة المصـرية باسـتخدام أسلوبي دلفى وبيرت، رسالة دكتور اه، كلية التربية، جامعة الزقازيق/فرع بنها. 


\section{استخدام أسلوب بيرت PERT في تخطيط برنامج لتدريب فرق التخطيط الاستراتيجي في الجامعات المصرية}

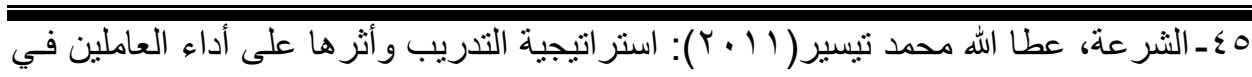
الثركات المساهمة العامة الصناعية الأردنية، دار جليس الزمان، عمان، الأردن.

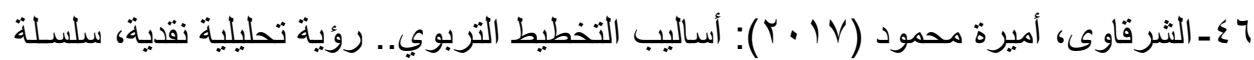
التربية والمستقبل العربى(^)، نوزيع مكتبة الأنجلو المصرية، القاهرة.

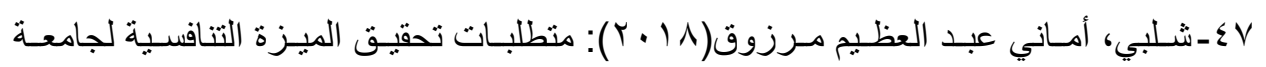
المنصورة في ضوء بعض الخبرات العالمية.. رؤية تربوية معاصرة، رسالة دكتور اه، كلية التربية، جامعة المنصورة.

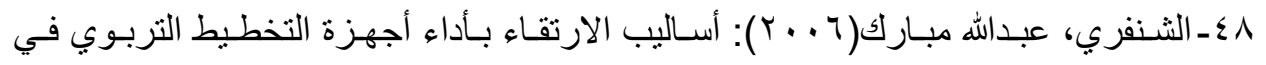

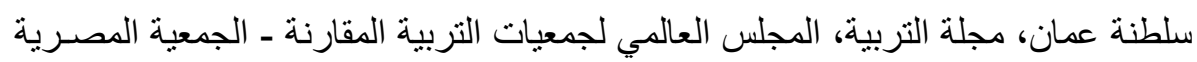
للتربية المقارنة والإدارة التعليمية ، المجلد التاسع، العدد(· ب).

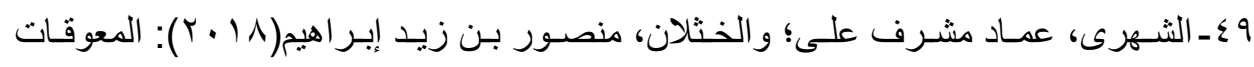

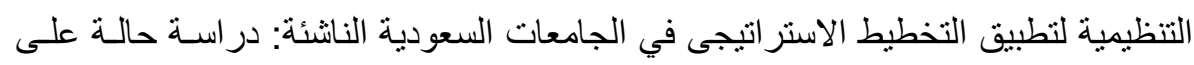

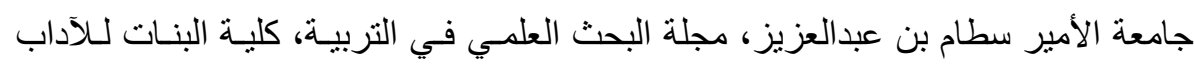
و العلوم و التربية، جامعة عين شمس، العدد (9 (1)، الجزء هـ الثناني.

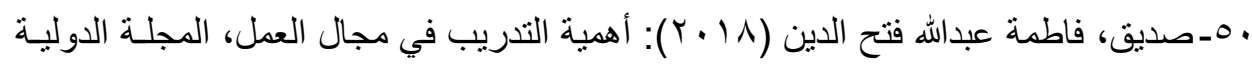

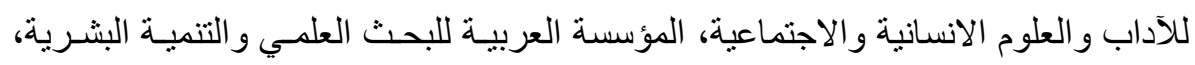

$$
\text { العدد التاسع، الجزء الأول، مايو. }
$$

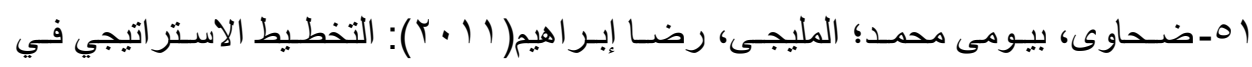
التعليم.. رؤية مستقبلية ونماذج تطبيقية، دار الفكر العربي، القاهرة.

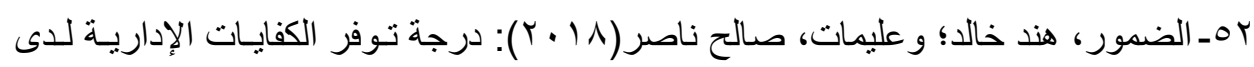

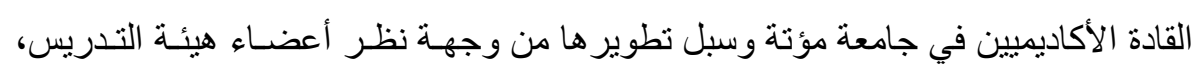

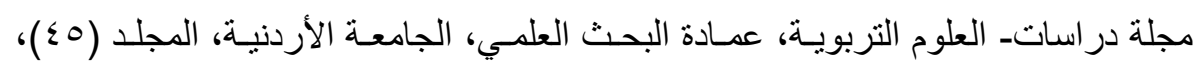

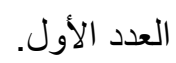




\section{د/ وفـاء عبد الفتــاح محمـود}

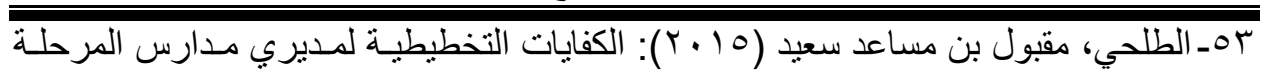
الثانوية بمدينة الطائف من وجهة نظر المعلمين، مجلة كلية التربية، جامعـة الأزهـر، العدد العدية

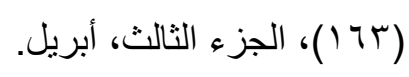

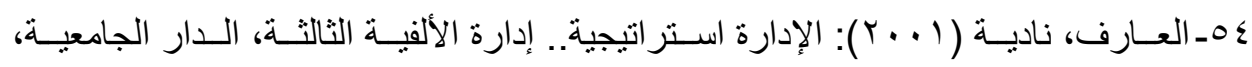

$$
\text { الإسكندرية. }
$$

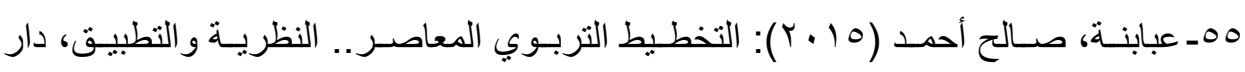

$$
\text { المسيرة، عمان. }
$$

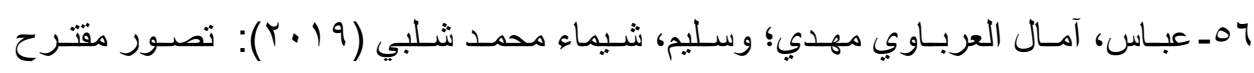
لاستخدام بحوث الفعل لتتمية الكفايـات المهنيـة والإداريـة لمشـرفي التربيـة العمليـة بكليـات

$$
\text { التربية، مجلة كلية التربية، جامعة بورسعيد، العدد (و ب)، يناير. }
$$

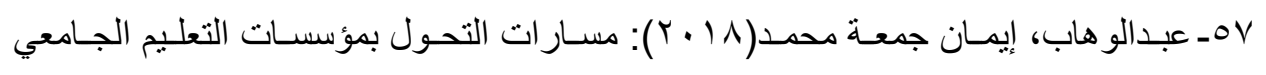
المصري نحو صيغة الجامعة الريادية.. در اسة إستشر افية، مجلة كلية التربية، جامعـة كفر

$$
\text { الشيخ، المجلد (1) (1)، العدد الأول. }
$$

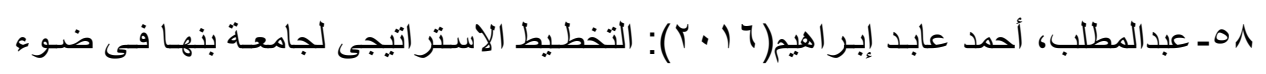
متطلبات التنافسية، رسالة دكتور اه، كلية التربية، جامعة بنها. 9هـ عز ازي، فاتن محمد عبد المنعم (10 ـ ب): التخطيط الاستر اتيجي لمؤسسات التعليم العـالي،

$$
\text { دار الز هر اء، الرياض. }
$$

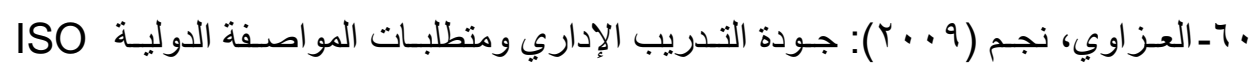

$$
\text { 10015، دار اليازوري العلمية للنشر و التوزيع، عمان. }
$$

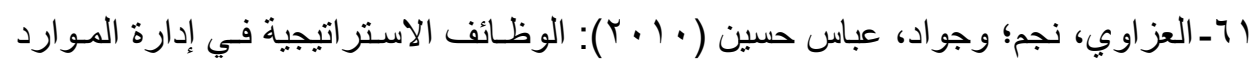

$$
\text { البشرية، دار اليازوري للنشر و التوزيع، عمان، الأردن. }
$$

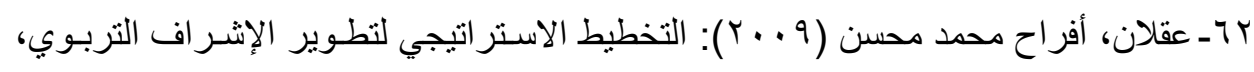

$$
\text { دار الوفاء، الإسكندرية. }
$$

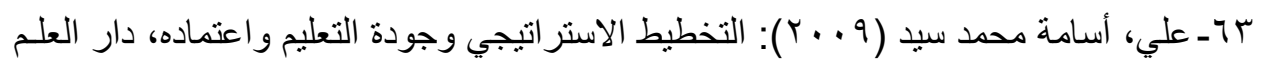
و الإيمان، كفر الثيخ.

$$
\begin{aligned}
& \text { العدد الخامس والاربعون (الجزء الاول) اجr.r } \\
& \text { مجلة كلية التربية- جامعة عين شمس }
\end{aligned}
$$




\section{استخدام أسلوب بيرت PERT في تخطيط برنامج لتدريب فرق التخطيط الاستراتيجي في الجامعات المصرية}

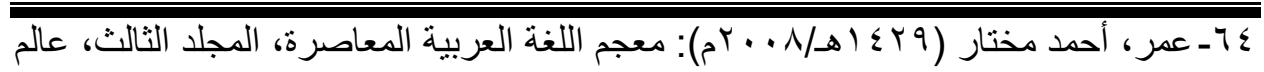
الكتب، القاهرة.

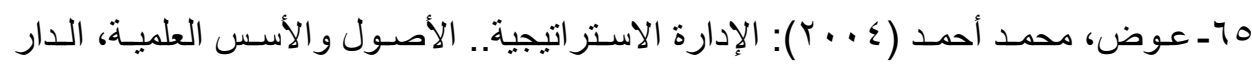
الجامعية، الإسكندرية.

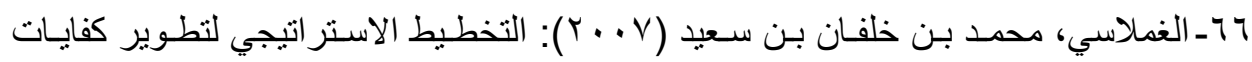

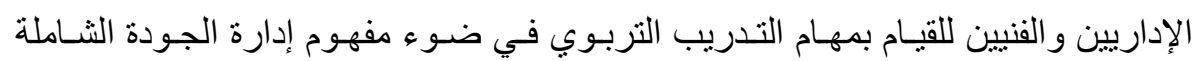
بسلطنة عمان، رسالة دكتور اه، كلية التربية، جامعة أم درمان الإسلامية، السودان.

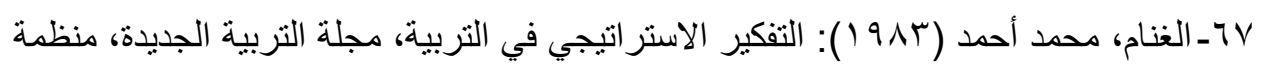

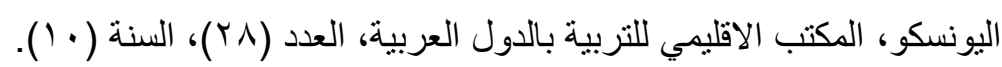

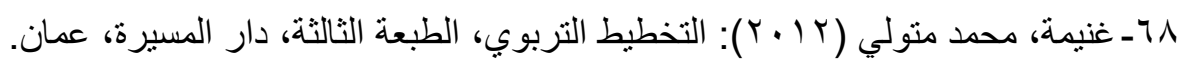

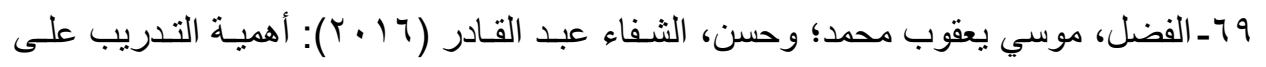
الكفايات التعليمية الأساسية لمعلمي ومعلمـات اللغـة العربيـة الحلقة الثانيـة بمرحلـة التعليم الأساسي بو لاية غرب كردفان.. محلية النهود دراسة ميدانية من وجهة نظر المعلمين، مجلة

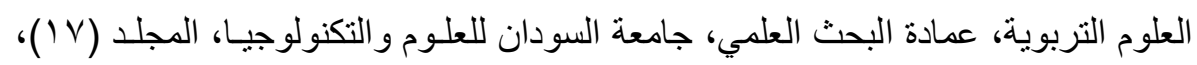
العدد الثناني.

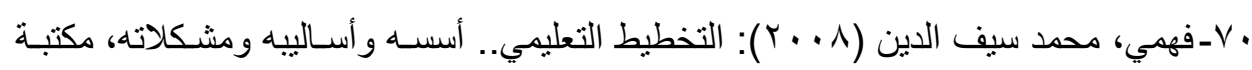

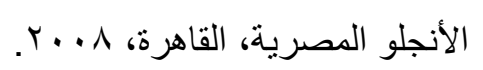

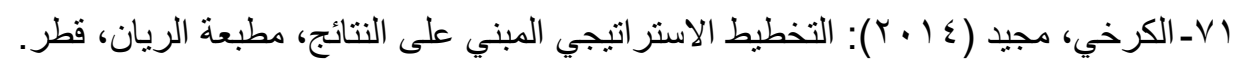

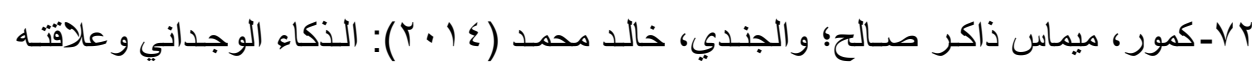

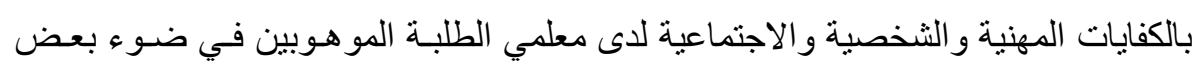

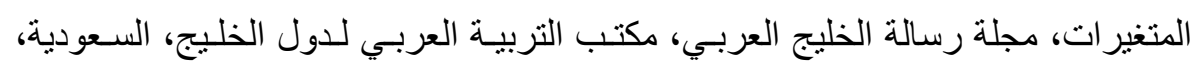

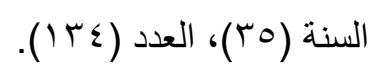

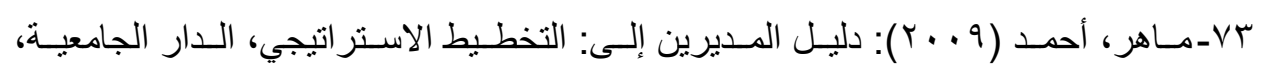
الإسكندرية.

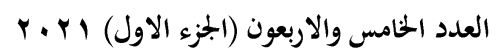

(308)
مجلة كلية التربية- جامعة عين شمس 


\section{د/ وفـاء عبد الفتــاح محمـود}

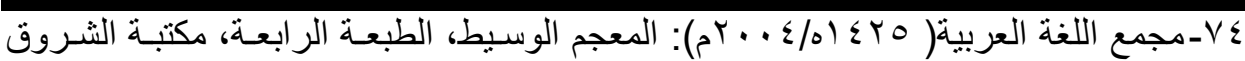

الدولية، القاهرة.

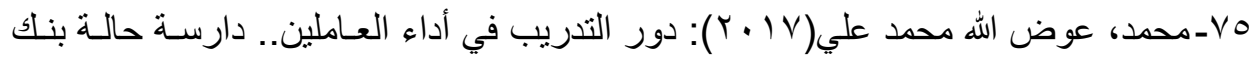

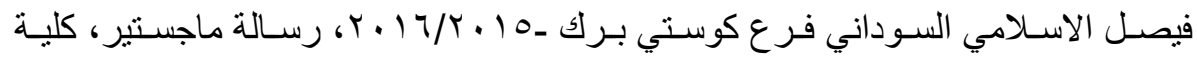
الاقتصاد و العلوم الإدارية، عمادة الدر اسات العليا، جامعة الإمام المهدي.

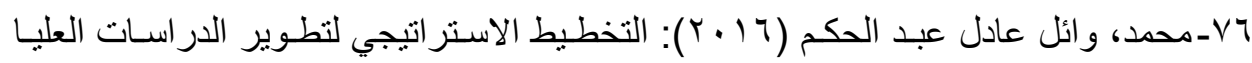

بكلية التربية جامعة المنيا، رسالة دكتور اه، كلية التربية، جامعة المنيا.

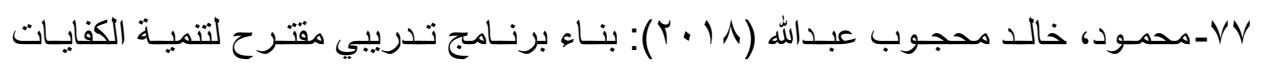
التعليمية الأدائية لمعلمات التعليم قبـل المدرسـة أثنـاء الخدمـة بولايـة الجزيـرة ــ السـودان، المجلة الدولية للار اسات النفسية والتربوية، مركز رفاد للار اسات والأبحاث، المجلد الثالث،

العدد الثالث.

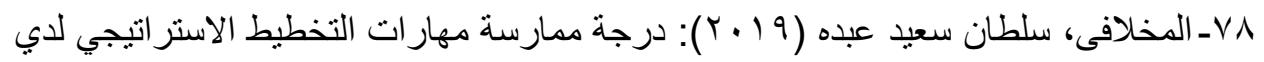
القيادات الأكاديمية بجامعة الملك خالـد مـن وجهـة نظـر أعضـاء هيئة التدريس بالجامعـة، المجلة العربية لضمان جودة التعليم الجـامعي، جامعـة العلوم و التكنولوجيـا، المجلد( ب ( )،

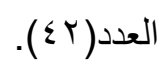

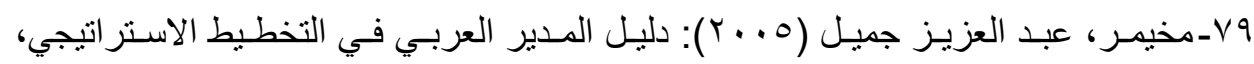

المنظمة العربية للتنمية الإدارية، القاهرة.

• ^-مدبولى، محمد عبد الخالق ( ( . . ץ): التخطبط المدرسي الاستر اتيجي، مكتبة الدار العربيـة

للكتاب، القاهرة.

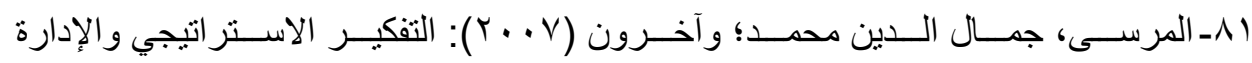
الاستر اتيجية.. منهج تطبيقي، الدار الجامعية، الإسكندرية.

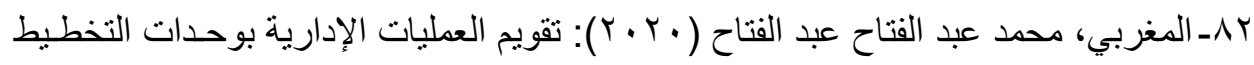
الاسترتيجي في الجامعات المصرية، مجلة كلية التربية، جامعـة عبن شـس، العـد (ع )، الجزء الثالث. 


\section{استخدام أسلوب بيرت PERT في تخطيط برنامج لتدربب فرق التخطيط الاستراتيجي في الجامعات المصرية}

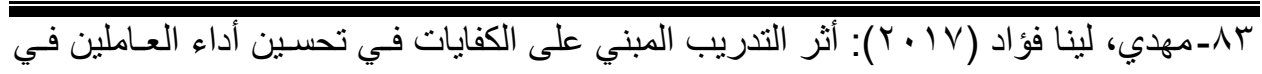

المستشفيات الجامعية الأردنية، رسالة ماجستير، كلية الأعمال، جامعة عمان العربية. ع ^ـ المو افي، محمد فتحي بدر (9>9 ( )): استخدام المسار الحرج في المفاضلة بين كلفة البدائل،

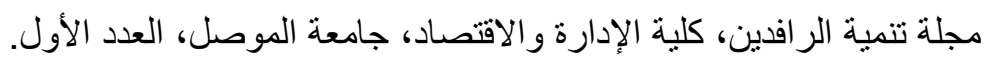

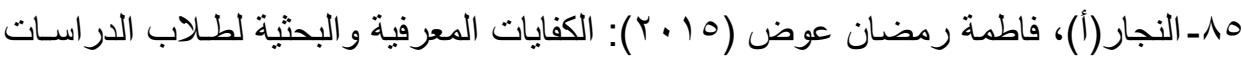
العليا في ضو ه منطلبات اقتصاد المعرفة، رسالة دكتور اه، كلية التربية، جامعة كفر الثيخ.

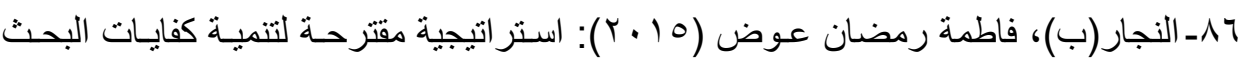
العلمي لدى طلاب الدراسات العليا في ضوء منطلبات اقتصاد المعرفة، مجلة كلية التربيـة، جامعة المنوفية، العدد الرابع، السنة (• (؟).

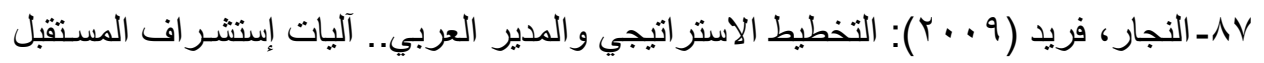
عام •0. • بم، الدار الجامعية، الإسكندرية.

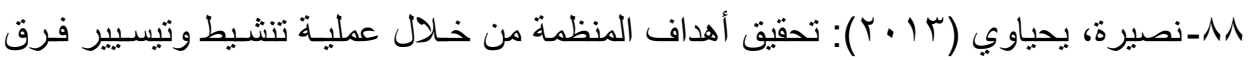

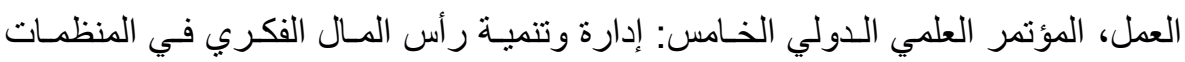

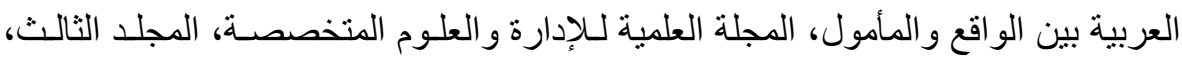

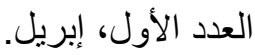

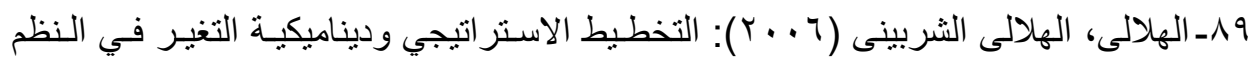
التعليمية، المكتبة العصرية، المنصورة.

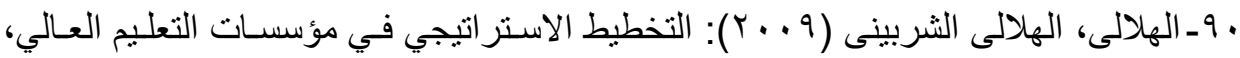
مجلة بحوث التربية النوعية، كلية التربية النوعية، جامعة المنصورة، العدد (ع ()، مايو.

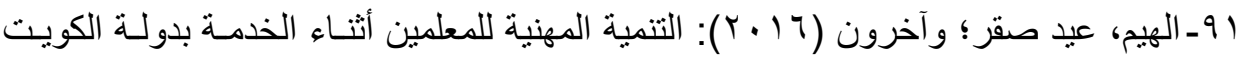

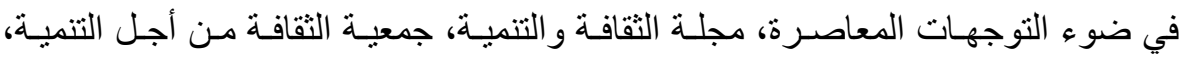

$$
\text { مصر ، السنة (7 (1)، العدد ( ( 1 ). }
$$

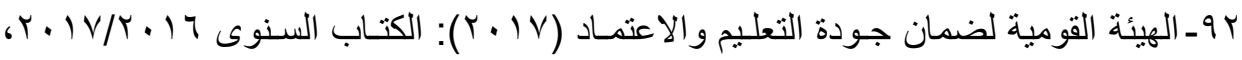
مجلس الوزر اء، الهيئة القومية لضمان جودة التعليم والاعتماد، القاهرة.

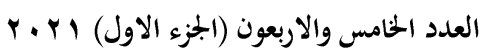

$(310)$
مجلة كلية التربية- جامعة عين شمس 


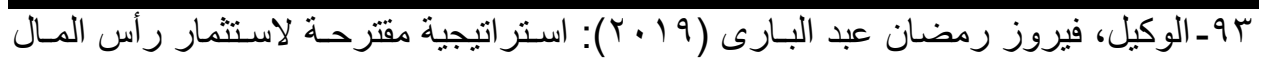

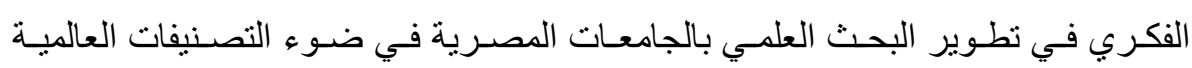

$$
\text { للجامعات، رسالة دكتور اه، كلية التربية، جامعة طنطا. }
$$

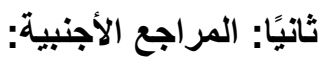

1- Akanwa, U. N. \& Eluwa, I. O.(2014): Evaluating Competency Enhancement Needs of Lecturers for Quality Teaching and Learning in South-East Universities of Nigeria, IOSR Journal of Research \& Method in Education (IOSR-JRME), Vol.4, Issue 2.

2- Boston, Deborah Anne (2016): Academic Leader Perceptions of Collective Efficacy in Higher Education Strategic Planning, Doctor of Philosophy thesis, North Carolina Agricultural and Technical State University, Greensboro, North Carolina .

3- Bryson, John M. \& Alston, Farnum K.(2005): Creating and Implementing Your Strategic Plan: A Workbook for Public and Nonprofit Organizations, 2nd ed., Jossey-Bass, San Francisco.

4- Carpenter, Rosalie A. (2019): The Effects of Executive Leadership on Higher Education Strategic Planning, Doctorate of Educational Leadership Thesis, Faculty of the University of South Alabama, Mobile County, Alabama.

5- Centor, Joshua A. ( 2016): Decision-Making in Higher Education: Strategic Planning and Resource Allocation at Elite Private Universities in The United States, Doctor of Philosophy Thesis, Faculty of The School of Education, University of Pittsburgh, Pittsburgh, Pennsylvania. 
استخام أسلوب بيرت PERT في تخطيط برنامج لتتريب فرق التخطيط الاستراتيجي في الجامعات المصرية

6- Chang, Hsien-Kuan, et. al (2019): The Use of A Multiple Risk Level Model to Tackle The Duration of Risk for Construction Activity, Journal of Korean Society Civil Engineers (KSCE), Vol.23, No.6.

7- El- Hout, Mohamed Sabry(1994): Strategic Planning for Educational System: Necessity and Methodology, Journal of Educational Planning and Administration, Vol. III, No.1, January.

8- Fumasoli, Tatiana (2020): Strategic Planning in Higher Education, in Teixeira, P. N.\& Shin, J. C. (eds.): The International Encyclopedia of Higher Education Systems and Institutions, Springer Nature B.V., London.

9- Gass, S.I.\& Fu, M.C. (eds.) (2013): Encyclopedia of Operations Research and Management Science, Springer Science+ Business Media, New York.

10- Girija, V.R. \& Bhat, M.S. (2013): Process Flow Analysis in The Emergency Department of A Tertiary Care Hospital Using Program Evaluation and Review Technique (PERT), Journal of Health Management, Vol.15, No.3.

11- Kriemadis, Athanasios (1997): Strategic Planning in Higher Education Athletic Departments, International Journal of Educational Management, Vol. 11, No. 6. 
12- Lerner, Alexandar L. (1999): A Strategic Planning Primer for Higher Education, College of Business Administration and Economics, California University, Berkeley.

13- lozier, G. Gregory (1995): What is Strategic Planning?, In Alvino, Kathleen M.(ed.): Strategic Planning, A Human Resource Tool for Higher Education, College and University Personnel Association, Washington, D.C.

14- Lugemwa, Peter (2014): Improving The Secondary School Curriculum to Nurture Entrepreneurial Competences Among Students in Uganda, International Journal of Secondary Education, Vol.2, No.4.

15- Luxton, Andrea (2005): Strategic Planning in Higher Education, Higher Education Management Series(1), General Conference Department of Education, Berrien Springs, Michigan.

16- Malik, Zafar I., et. al (2011): Training Manual: Use of Data for Educational Planning and Management, National Education Management Information System, Academy of Educational Planning and Management, Ministry of Professional \& Technical Training, Islamabad.

17- Rand, Graham K. (2001): Program Evaluation and Review Technique (PERT): Project Management, in Gass, S. I. et.al., (eds.): Encyclopedia of Operations Research and Management Science, Kluwer Academic Publishers, Dordrecht, The Netherlands. 
استخام أسلوب بيرت PERT في تخطيط برنامج لتتريب فرق التخطيط الاستراتيجي في الجامعات المصرية

18- Sackey, Solomon \& Kim, Byung-Soo(2019): Schedule Risk Analysis using a Proposed Modified Variance and Mean of the Original Program Evaluation and Review Technique Model, KSCE Journal of Civil Engineering, Vol.23, No. 4.

19- Smith, Charles Christopher (2008): Superpath: A NonComputerized Probabilistic Scheduling Methodology Using First Principles of The U. S. Navy's Program Evaluation Review Technique, Doctor of Philosophy Thesis, Faculty of The Graduate School of The University of Maryland, College Park, Maryland.

20- Stor, Marzena \& Kupczyk, Teresa (2015): Differences in Competency Management - Comparative Analysis between Polish, Spanish, and Austrian Business Practices, Journal of Intercultural Management, Vol. 7, No. 2, June.

21- Udoh, Arit E. (2016): Identifying and Evaluating Foundation and Advanced Pharmacy Practice Competencies in a Global Context, Doctor of Philosophy Thesis, School of Pharmacy, University of California, Los Angeles.

22- Unesco(A) (2010): Distance Education Programme on Education Sector Planning, Module 1: Educational Planning: approaches, challenges and international frameworks, IIEP, Unesco, Paris. 
23- Unesco(B) (2010): Strategic planning: Organizational arrangements, Education Sector Planning Working Papers, Working Paper2, IIEP, Unesco, Paris.

24- Unesco (2015): Guidelines for Education Sector Plan Preparation, International Institute for Educational Planning, Unesco, Paris.

25- University of Oxford (2016): International Trends in Higher Education 2015, the International Strategy Office, University Offices, Wellington Square, Oxford.

26- Wagiran, Pardjono, et. al (2019): Competencies of Future Vocational Teachers: Perspective of In-Service Teachers and Educational Experts, Journal of Cakrawala Pendidikan, Vol. 38, No. 2, June. 


\section{استخدام أسلوب بيرت PERT في تخطيط برنامج لتدربب فرق التخطيط الاستراتيجي في الجامعات المصرية فيطامجية}

\section{ملحق (1)}

أسماء السادة الأساتذة في المقابلة الثخصية (*)

\begin{tabular}{|c|c|}
\hline الدرجة الوظيفية & 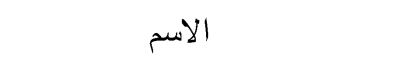 \\
\hline وأستاذ المناهج وطرق تدريس العلوم ومدير مركز المعلومات & أ.د/ إبراهيم عبد العزيز البعلي \\
\hline أستاذ أصول التربية المساعد- كلية التربية- جامعة بنها & أ.م.دد/ إيمان جمعة محمد \\
\hline مدرس علم النفس التربوي ومدير وحدة التخطيط الاستراتيجي بكلية & د/ رانيا محمد سالم \\
\hline أستاذ التخطيط التربوي- كلية التربية - جامعة الزقازيق & أ.دم/ محمد صبري الحوت \\
\hline وأستاذ المناهج وطرق تدريس اللغة الإنجليزية ووكيل خدمة البيئة & أ.د/ منى سالم محمود زعزع \\
\hline 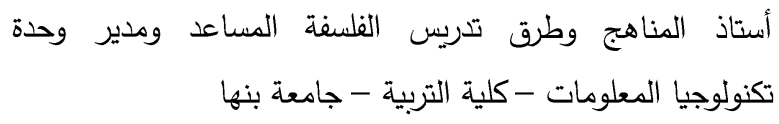 & أ.م.د/ ميساء محمد مصطفي حمزة \\
\hline أستاذ التخطيط التربوي ومدير وحدة ضمان الجودة سابقا- كلية & أ.د/ ناديه حسن السيد \\
\hline أستاذ أصول التربية - كلية التربية - جامعة بنها & أ.د/ وضيئة محمد أبو سعده \\
\hline
\end{tabular}

(") نم ترتيب السادة الأساتذة تبعاً للحروف الأبجدية.

العدد الحامس والاربعون (الجزء الاول) ا ب. F

(316)

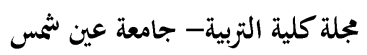

